INÊS SLEIMAN MOLINA JAZZAR

\title{
MEDIAÇÃO E CONFLITOS COLETIVOS DE TRABALHO
}

\author{
DisSERTAÇÃo DE MESTRAdo
}

Orientador: Prof. Dr. Antonio Rodrigues de Freitas JÚNior

FACULDADE DE DIREITO DA USP

SÃO PAULO

2008 
INÊS SLEIMAN MOLINA JAZZAR

\title{
MEDIAÇÃO E CONFLITOS COLETIVOS DE TRABALHO
}

\author{
Dissertação apresentada ao Departamento de Direito \\ do Trabalho da Faculdade de Direito da Universidade \\ de São Paulo como requisito parcial para obtenção do \\ título de Mestre em Direito, sob orientação do Prof. \\ Dr. Antonio Rodrigues de Freitas Júnior
}

FACULDADE DE DIREITO DA USP

SÃO PAULO

2008 
Agradeço aos meus pais, Nadime e Oswaldo, responsáveis pela minha formação.

Às minhas filhas, Elis e Maira, fontes de energia $e$ inspiração, que tiveram a paciência de aguardar pela finalização deste trabalho.

Ao meu marido, Georges, companheiro e incentivador, sempre pronto a compreender e ajudar.

Aos meus irmãos, Leila e Marcos, pelo carinho e apoio que sempre me deram.

Aos meus amigos e colegas de trabalho, por todo apoio e dedicação prestados.

Ao meu orientador Antônio Rodrigues de Freitas Junior, pela oportunidade de compartilhar seus conhecimentos $e$ me direcionar neste aprendizado. 


\section{RESUMO}

O presente trabalho visa a uma reflexão sobre necessidade da utilização da mediação, como procedimento útil na administração dos conflitos coletivos de trabalho. Pondera-se que o desenvolvimento da mediação em todos os campos da vida social não deve ser apresentado apenas como uma alternativa ao Judiciário, e sim como um novo modo de regulação social, que prioriza a reconstrução das relações futuras e o respeito às suas necessidades específicas.

Partindo do conceito de conflito, dos fatores que o influenciam, de suas formas de exteriorização e de suas especificidades no direito coletivo do trabalho, o estudo questiona se o excessivo intervencionismo estatal presente em nosso ordenamento jurídico não limita a efetiva autonomia sindical e engessa o comportamento dos grupos sociais.

Trata do contra-senso existente entre o ilusório estímulo à negociação coletiva e o reconhecimento da solução jurisdicional compulsória, já que o Poder normativo ainda é o meio utilizado para tornar certo o conflito coletivo do trabalho.

Propõe um conceito da mediação, indicando seus objetivos, princípios e diferenciando-a dos demais meios de solução de conflitos. Procura esclarecer de que maneira a mediação pode ser utilizada como instrumento de transformação cultural e pacificação social, abordando-a como meio capaz de auxiliar o Poder Judiciário, tanto no aspecto da diminuição do número de ações judiciais, quanto na utilização de seus métodos para aprimoramento da atividade jurisdicional.

O acesso à Justiça é um direito fundamental, que não está limitado ao acesso ao Poder Judiciário, podendo servir de ferramenta às organizações da sociedade civil para pressionar o Estado na busca da realização de políticas públicas eficientes, com vistas à disponibilização de instrumentos jurídicos necessários à aproximação do Direito da idéia de Justiça como força transformadora dos conflitos. Trata, assim, da necessidade de desenvolvimento de uma política pública de incentivo à utilização da mediação como instrumento de acesso à Justiça, voltada à construção de uma cultura da paz e à manutenção das relações continuadas.

Palavras-chave: mediação; conflitos coletivos de trabalho; cultura da paz; negociação coletiva; acesso à Justiça. 


\section{ABSTRACT}

The present work objectives a reflection on the need of mediation as a useful process in the management of collective labor conflicts. It is considered that the development of mediation in all fields of social life should not be presented exclusively as an alternative to the Judiciary, but as a new mode of social regulation, which gives priority to the reconstruction of future relations and the respect to its specific needs.

Assuming the concept of conflict, of the factors that influence it, of its forms of outward expression and of its particularities in the collective right of labor, the study investigates if the excessive state interventionism present in our juridical ordinance does not limit the effective union autonomy and controls the behavior of social groups.

It deals with the existing paradox between the apparent stimulus to collective negotiation and the acknowledgement of compulsory jurisdictional solution, once the normative Power still is the used mean to make right the collective labor conflict.

A concept of mediation is proposed, appointing its objectives, principles and differentiating it from the other means of solution for conflicts. It attempts to make clear that a mean of mediation may be used as an instrument of cultural modification and social pacification, approaching it as an able mean to help the Judiciary, both on the reduction of the number of juridical suits, and on the employment of its methods for the improvement of jurisdictional activity.

The access to Justice is an essential right, which is not limited to the access of the Judiciary, being able to serve as a tool for organizations of civil society to pressure the State on the search of effective public policies, examining the availability of necessary juridical instruments in the approach of Law to the notion of Justice as a transforming strength of conflicts. It deals with the need of the development of a public policy of incentive to the employment of mediation an instrumental of acess to Justice, facing the construction of peace culture and of the maintenance of continuous relations.

Keywords: mediation; collective labor conflicts; peace culture; collective negotiation; access to Justice 


\section{SUMÁRIO}

INTRODUÇÃO

CAPÍTULO 1. CONFLITOS SOCIAIS

1.1. Funções positivas do conflito

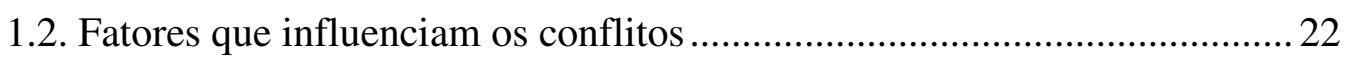

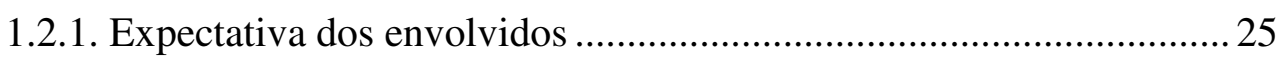

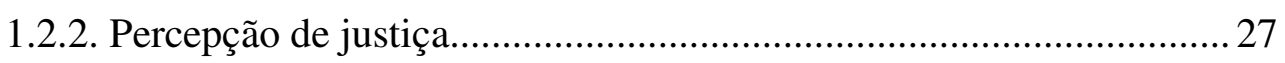

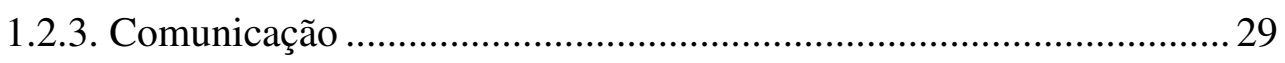

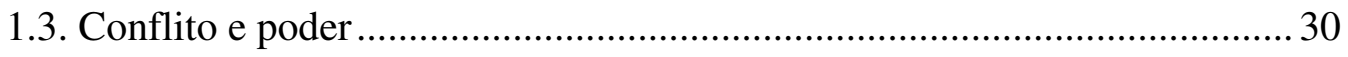

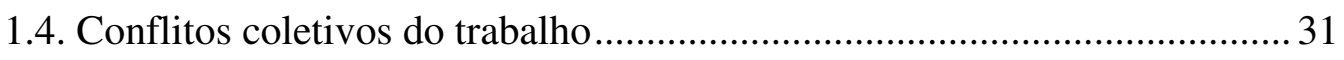

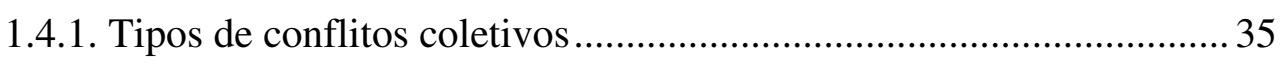

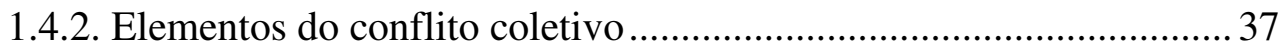

1.4.2.1. Elemento material........................................................... 37

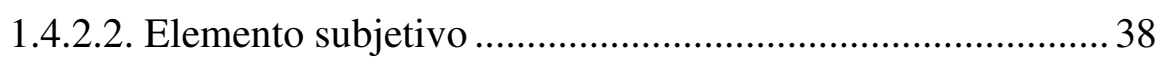

1.4.2.3. Elemento objetivo............................................................ 39

1.4.2.4. Interesse comprometido.................................................... 40

1.5. Limites do Judiciário para absorver e decidir os conflitos coletivos

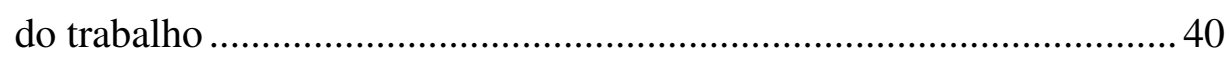

\section{CAPÍTULO 2. FORMAS DE COMPOSIÇÃO DOS CONFLITOS COLETIVOS}

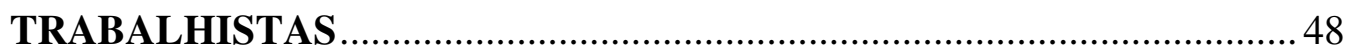

2.1. Meios de soluções para os conflitos coletivos de trabalho ......................... 48

2.2. Acesso à Justiça: modernização do conceito ............................................. 51

2.3. ONU e Cultura da Paz ............................................................................. 56

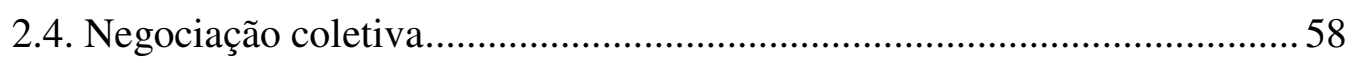

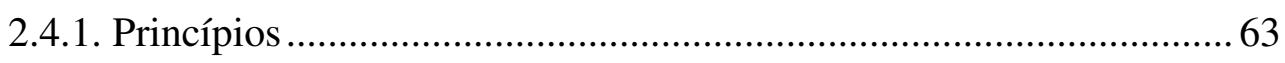

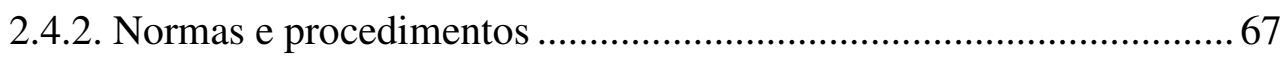

2.4.3. Técnicas de negociação ................................................................. 70

2.4.3.1. Negociação distributiva ou posicional................................. 71

2.4.3.2. Negociação integrativa ...................................................... 72

2.4.3.3. Diferenças entre interesses e posições. Procedimento na negociação baseada em interesses ................................ 73

2.5. Solução Jurisdicional. Poder normativo …….......................................... 75 
2.6. Conciliação na Justiça do Trabalho: Judiciária e Administrativa.

Comissões de Conciliação Prévia.

CAPÍTULO 3. MEDIAÇÃO 82

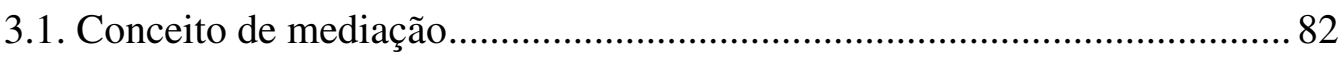

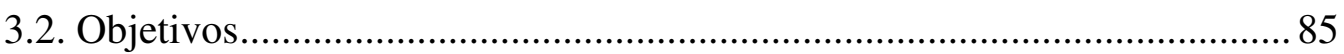

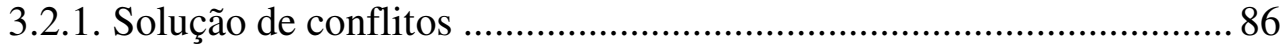

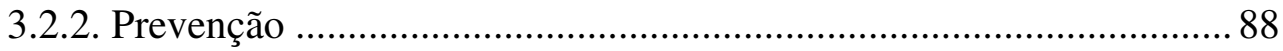

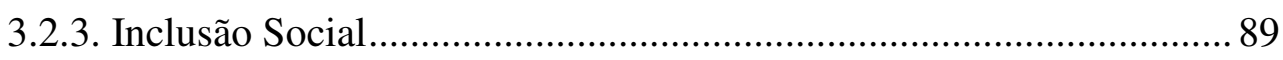

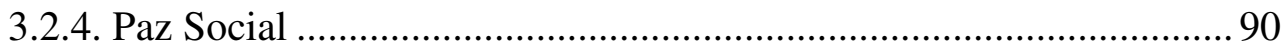

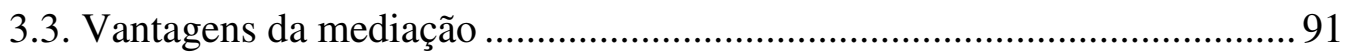

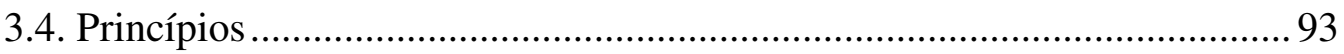

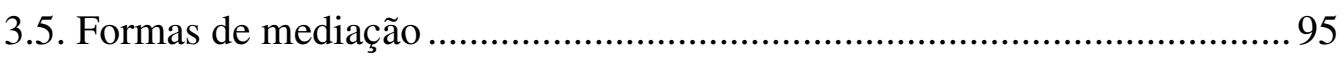

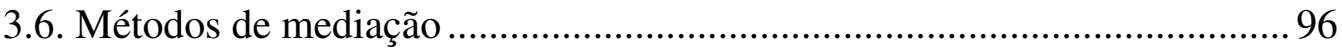

3.7. Diferenças com outros meios alternativos de composição dos

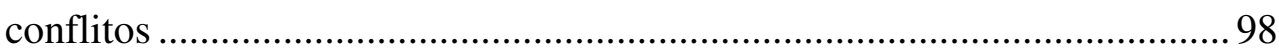

3.8. Judiciário e mediação: complementação em objetivos comuns (transformação social)

CAPÍTULO 4. MEDIAÇÃO NOS CONFLITOS COLETIVOS DE TRABALHO .......... 104

4.1. Histórico de Institucionalização da Mediação no Brasil ......................... 106

4.2. Institucionalização da Mediação no Direito Coletivo de Trabalho .......... 110

4.3. Mediador - Funções, Papéis e Código de Ética e Mediação pelo Ministério do Trabalho e Ministério Público do Trabalho ....................... 112

4.4. Experiências no Direito Estrangeiro..................................................... 118

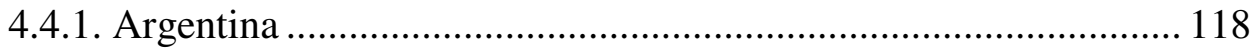

4.4.2. França ….............................................................................. 120

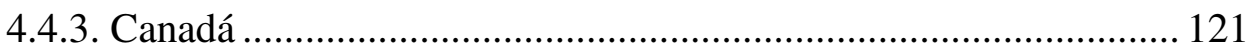

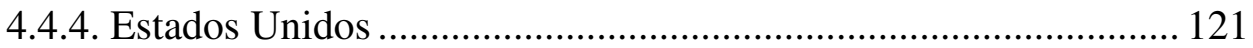

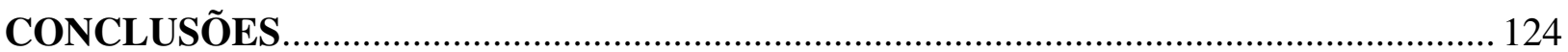

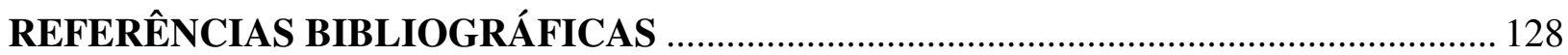

ANEXOS 


\section{INTRODUÇÃO}

A mediação, como método de resolução de conflitos, representa um importante mecanismo de pacificação social, cujos resultados trazem, na maioria das vezes, uma maior satisfação às partes envolvidas. $\mathrm{O}$ desenvolvimento da mediação em todos os campos da vida social não deve ser apresentado apenas como uma alternativa ao Judiciário e sim como um novo modo de regulação social, que prioriza a reconstrução das relações futuras e o respeito às suas necessidades específicas.

O presente trabalho visa a uma reflexão sobre a necessidade de desenvolvimento de uma política nacional de incentivo aos mecanismos necessários para a obtenção da autocomposição, transformando o papel do Estado de extremo intervencionista para o de incentivador e supervisor do diálogo dos envolvidos nos conflitos. Tal incentivo reforça a comunicação das partes e representa uma contribuição para o crescimento e para uma mudança nas condutas sociais.

A intenção não é propor a utilização de meios alternativos de solução de conflitos apenas como solução para a atual crise do Poder Judiciário, manifestada pelo congestionamento dos tribunais e pela demora na tramitação dos feitos. Propõe-se observar outras formas de solução de conflitos, através do estudo sistemático da autocomposição, em especial, o estudo da mediação.

Como tarefa do Estado, a jurisdição tem sido exercida como único meio de solução dos conflitos. A exemplo de outros países ${ }^{1}$, com Poder Judiciário forte e independente, o Estado deve compreender que sua tarefa pacificadora é mais ampla do que a exercida pelo Judiciário. Assim, é função do Estado proporcionar meios para que todos os instrumentos adequados para a solução dos conflitos sejam utilizados.

Durante muito tempo o processo jurisdicional representava uma enorme conquista da civilização, enquanto a autocomposição e a heterocomposição foram consideradas instrumentos próprios das sociedades primitivas. Hoje, no entanto, reacende a

\footnotetext{
${ }^{1}$ Países como o Canadá, França, EUA, Bélgica, reconhecidos por terem um sistema judiciário forte, adotam a mediação como uma das formas de resolução dos conflitos.
} 
procura pelas vias alternativas $^{2}$ de pacificação social, que, necessariamente, não exclui o processo judicial. A chamada "cultura de conciliação"3 assume importante papel de promoção de conscientização política e indica a institucionalização de novas formas de participação na administração da justiça.

O renascer das vias conciliatórias apresenta três fundamentos principais: fundamento funcional, social e político ${ }^{4}$. O primeiro é reflexo da crise da Justiça, decorrente de sua inacessibilidade, morosidade e custo. Trata-se de buscar a racionalização na distribuição da Justiça pela atribuição de certas controvérsias a instrumentos institucionalizados que buscam a autocomposição e, ainda, de recuperar certas controvérsias, que permaneceriam sem solução na sociedade contemporânea, perante a inadequação da técnica processual para a solução de questões que a envolvem. Nesse enfoque, a mediação e a conciliação tornam-se equivalentes jurisdicionais e passam ao status de instrumentos utilizados no quadro da política judiciária.

O fundamento social das vias conciliativas ${ }^{5}$ consiste na sua função de pacificação social e busca, além de atender aos reclamos de funcionalidade e eficiência do aparelho jurisdicional, permitir, através dos equivalentes jurisdicionais, a solução de controvérsias que muitas vezes sequer chegam a ser apreciadas pela justiça tradicional, que se limita a ditar autoritariamente a regra para o caso concreto, de acordo com a parcela da lide levada a juízo, sem a possibilidade de pacificar a lide sociológica, em geral mais ampla ${ }^{6}$.

O fundamento político refere-se ao aspecto da participação popular na administração da justiça, pela colaboração do corpo social nos procedimentos da mediação e conciliação. Decorre do princípio participativo da democracia e consiste na efetiva intervenção no momento da decisão e no controle sobre o exercício do poder. A atuação de leigos na função conciliatória confere a possibilidade de participação popular no âmbito da justiça, configurando meio de intervenção popular na administração da justiça.

\footnotetext{
${ }^{2}$ Entendendo como tais, todas as modalidades de soluções não-juridicionais dos conflitos, a exemplo do que conceitua CINTRA, Antônio Carlos Araújo; DINAMARCO, Cândido Rangel; GRINOVER, Ada Pelegrini. Teoria geral do processo. 14. ed. São Paulo: Malheiros Ed., 1998. p. 26.

${ }^{3}$ GRINOVER, Ada Pelegrini. Os fundamentos da justiça conciliativa. In: ; WATANABE, Kazuo, LAGRASTA NETO, Caetano. Mediação e gerenciamento do processo: revolução na prestação jurisdicional: guia prático para a instalação do setor de conciliação e arbitragem. São Paulo: Atlas, 2007. p. 2-3.

${ }^{4}$ Id. Ibid., p. 3-6.

${ }^{5}$ Seguindo a expressão utilizada pela Ada Pelegrini Grinover na obra acima referida.

${ }^{6}$ Segundo a autora: "a justiça tradicional se volta para o passado, enquanto a justiça informal se dirige ao futuro. A primeira julga e sentencia; a segunda compõe, concilia, previne situações de tensões e rupturas, exatamente onde a coexistência é um relevante elemento valorativo".
} 
Assim, dentro de um conceito amplo de jurisdição, como função pública voltada à pacificação de conflitos, observa-se que a mediação é um importante instrumento de pacificação social na medida em que, como veremos adiante, apresenta uma nova abordagem do conflito e proporciona a formação de sujeitos responsáveis, aptos a explorar seus próprios valores de justiça.

Com o procedimento da mediação busca-se alinhar uma visão muito mais voltada para as relações interpessoais, tendo como premissa básica o relacionamento pós-conflito, diferente da visão mais comum do processo judicial, que visa o passado e a resolução da controvérsia em si mesma. Isso se torna particularmente relevante quando entre as partes persistem relações duráveis, complexas e que merecem ser conservadas.

As técnicas da mediação permitem que os interessados lidem com suas disputas de forma positiva e adequada, por facilitar e estimular o diálogo entre as partes, transformando-as em protagonistas de suas próprias histórias, o que favorece o desenvolvimento do respeito às diversidades, dando, assim, uma nova feição ao conflito e às partes nele envolvidas. $\mathrm{O}$ restabelecimento da comunicação propicia, ainda, um maior equilíbrio, o que facilita a coesão social necessária à vida em comum.

A investigação sobre a utilização da mediação como meio alternativo à resolução de conflitos traz à baila alguns questionamentos sobre o acesso à justiça. A idéia de que o acesso aos órgãos judiciais constitua o único significado da acepção jurídica de acesso à justiça demonstra-se ultrapassada e equivocada, pois, atualmente, a preocupação fundamental é com a "justiça social", que visa a busca de procedimentos que sejam condizentes à proteção dos direitos e administração dos conflitos. O fenômeno do acesso à Justiça deve ser compreendido como a possibilidade material de conviver em uma sociedade onde o Direito e a Justiça são realizados de forma concreta, seja por meio da atuação judiciária do Estado, através de seu poder soberano, seja por meio do estímulo ao uso das formas prévias e alternativas de resolução de conflitos. Necessário enfatizar que os valores centrais do processo judiciário tradicional devem ser mantidos e que o "acesso à justiça" deve englobar as duas formas de processo ${ }^{7}$.

Assim, o preceito constitucional que assegura o acesso à Justiça traz, implicitamente, o princípio da adequação, garantindo não apenas o acesso ao Judiciário, mas também a obtenção de uma solução adequada ao tipo do conflito existente. Necessário

${ }^{7}$ CAPPELLETTI, Mauro; GARTH, Bryant. Acesso à justiça. Tradução de Ellen Gracie Northfleet. Porto Alegre: Fabris, 1998. p. 93. 
esclarecer que o "acesso à justiça" não está diretamente ligado ao "acesso ao Judiciário". O primeiro está ligado ao acesso à ordem jurídica justa, que independe do acesso à jurisdição. Tanto é verdade que existem formas extrajudiciais de resolução de conflitos sem a intervenção estatal. Já o "acesso ao Judiciário" está relacionado com o direito de ação e com o princípio constitucional da inafastabilidade da jurisdição ${ }^{8}$.

A cultura de cooperação presente na mediação vai ao encontro do cenário contemporâneo de luta em favor da promoção e fortalecimento da Cultura da Paz. Note-se que no ano de 1997, a Assembléia Geral das Nações Unidas proclamou o Ano 2000 como o Ano Internacional da Cultura da Paz e o período de 2001 a 2010 como a "Década Internacional por uma Cultura de Paz e Não-violência", conferindo à UNESCO (Organização das Nações Unidas para a Educação, Ciência e a Cultura) a coordenação do movimento mundial de transição da cultura da guerra para uma cultura de solidariedade. A Cultura da Paz tem dimensão universalista e é assim definida:

A Cultura da Paz é a Paz em ação; é o respeito aos direitos humanos no dia-a-dia; é um poder gerado por um triângulo interativo de paz, desenvolvimento e democracia. Enquanto cultura de vida, trata-se de tornar diferentes indivíduos capazes de viverem juntos, de criarem um novo sentido de compartilhar, ouvir e zelar uns pelos outros, e de assumir responsabilidade por sua participação numa sociedade democrática que luta contra a pobreza e a exclusão; ao mesmo tempo em que garante igualdade política, equidade social e diversidade cultural ${ }^{9}$.

Interessante constatar que a Declaração e Programa de Ação sobre uma Cultura da Paz, aprovada pela Organização das Nações Unidas em 13 de setembro de 1999, por meio da Resolução no 53/243, reconhece que "a paz não é apenas a ausência de conflitos, mas que também requer um processo positivo, dinâmico e participativo em que se promova o diálogo e se solucionem os conflitos dentro de um espírito de entendimento e cooperação mútuos" "10. E mais adiante (artigo $1^{\circ}$, letra "d") estabelece o compromisso com a solução pacífica dos conflitos como sendo um dos valores em que se baseia uma Cultura de Paz.

Destaque-se, ainda, que, na Resolução no 26 da ONU, de 28 de julho de 1999, o Conselho Econômico e Social das Nações Unidas recomenda que os Estados

\footnotetext{
${ }^{8}$ Art. $5^{\circ}$, XXXV: "A lei não excluirá da apreciação do Poder Judiciário lesão ou ameaça a direito".

${ }^{9}$ Definição retirada da Internet no site: COMITÊ PAULISTA PARA A DÉCADA DA CULTURA DE PAZ. Disponível em: <http://www.comitepaz.org.br/a_cultura_de_p.htm>. Acesso em: 12 dez. 2006.

${ }^{10}$ Resolução no 53/243 da Assembléia Geral da ONU.
} 
desenvolvam a promoção dos chamados ADRs - Alternative Dispute Resolution. No entanto, no Brasil, o meio usual de solução de conflitos ainda é exercido de maneira adjudicatória, por meio do Judiciário. Os meios alternativos encontram-se em fase de organização, sendo necessário o desenvolvimento de uma mentalidade receptiva aos novos modelos de solução e tratamento de conflitos.

Diante de todo esse cenário, pode-se afirmar que há manifesta necessidade de desenvolvimento de novos modelos que permitam que as partes, por meio de um procedimento próprio e participativo, resolvam suas disputas construtivamente, fortalecendo as relações sociais, identificando interesses subjacentes ao conflito e explorando estratégias que possam prevenir ou resolver futuras controvérsias. E a profissionalização do procedimento da mediação, com a formação de mediadores com preparo técnico e eqüidistantes, é condição que se faz necessária para aprimorar o papel que, atualmente, é basicamente cumprido pelo Poder Judiciário.

Não pretendemos tirar o mérito do poder judiciário, que ocupou importante papel de resolução dos conflitos num contexto específico. Nem é escopo deste trabalho culpá-lo pelas necessárias alterações nos modos de resolução de conflitos e pela busca da realização da justiça por meio extrajudicial. Há que se lembrar que por suas próprias características - exercício da jurisdição dentro da lide, inércia, definitividade e substitutividade - o Poder Judiciário está impedido de buscar soluções que não estejam delimitas pelo conflito a ele apresentado.

Nesse sentido, o presente trabalho propõe uma reflexão sobre a solução dos conflitos coletivos oriundos das relações de trabalho, destacando que os mecanismos atuais necessitam de aperfeiçoamento, principalmente porque muitas vezes as partes interessadas não envidam grandes esforços na negociação coletiva, exatamente por já terem definido o caminho do dissídio coletivo.

Propõe-se, assim, um conceito da mediação, indicando seus objetivos, princípios e diferenciando-a dos demais meios de solução de conflitos. Procura-se esclarecer de que maneira a mediação pode ser utilizada como instrumento de transformação cultural e pacificação social, abordando-a como meio capaz de auxiliar o Poder Judiciário, tanto no aspecto da diminuição do número de ações judiciais, quanto na utilização de seus métodos para aprimoramento da atividade jurisdicional. 


\section{JUSTIFICATIVA DA ESCOLHA E IMPORTÂNCIA DO TEMA}

Os conflitos de interesse são inevitáveis em qualquer sociedade. Como é corrente notar, a cultura jurídica dos sistemas de tradição romano-germânica privilegia a heterocomposição dos conflitos por meio de decisões impositivas, vinculadas aos limites objetivos de uma lide, o que favorece a disputa e o antagonismo entre as partes, sem possibilidade de questionar suas diversidades e necessidades reais.

Especialmente no campo do direito do trabalho, nosso sistema jurídico manteve a lógica do sistema corporativo, optando pela excessiva intervenção nos conflitos coletivos de trabalho. Assim, nosso modelo de regulação das relações coletivas de trabalho é marcado por um notável intervencionismo estatal, que está assentado em três eixos: legislação minuciosa e impositiva, organização sindical de molde corporativo e solução dos conflitos centrada na Justiça do Trabalho.

Ocorre que os conflitos coletivos de trabalho exigem uma resolução de conflitos diferenciada, que tenha como objetivo a pacificação dos envolvidos e, conseqüentemente, a permanência da relação continuada entre as partes e não apenas a solução da disputa.

A instituição e o incentivo à utilização de meios alternativos, como a mediação, é importante, por permitir que o conflito seja tratado de maneira construtiva, pacificando os interesses das partes e possibilitando a continuidade de uma convivência saudável. Como veremos no decorrer deste trabalho, a mediação, como método pacífico de resolução dos conflitos, difere da atuação estritamente jurídica, na medida em que busca reconhecer, aceitar e compreender as diferenças, com objetivo de encontrar o real interesse dos envolvidos.

O desenvolvimento e a aceitação da mediação, como forma prévia ou incidental ao processo judicial, não tem a pretensão de substituir o Judiciário na resolução dos conflitos. Como salienta Antônio Rodrigues de Freitas ${ }^{11}$, "uma atmosfera institucional em que o Judiciário funcione, de modo substancialmente público, democrático, acessível e eficaz, é condição necessária para o processo de mediação". Assim, a existência de um

\footnotetext{
${ }^{11}$ FREITAS JÚNIOR, Antonio Rodrigues. Mediação de conflitos: (Justiça pública não-judiciária e promoção da cultura da paz). Revista do Departamento de Direito do Trabalho e da Seguridade Social, São Paulo, v. 1, n. 2, p. 213, 2006.
} 
Judiciário forte aumenta a possibilidade de escolha (ou não) pela mediação como um meio alternativo de solução de conflitos em um sistema democrático. Em outras palavras, a mediação não será utilizada como instrumento de desafogo do Judiciário, visando apenas uma solução mais ágil e favorável à parte que dele se utiliza. As partes que utilizam tal método priorizam administrar suas divergências num ambiente de paz, de re-construção de seus conflitos.

Assim, é necessário mudar o espírito do sistema jurídico, priorizando a lógica da comunicação e da negociação no lugar da lógica de confronto judicial, que normalmente exacerba o próprio conflito. O sistema de decisão judiciária se expressa por uma lógica essencialmente binária, incapaz de acompanhar de maneira exclusiva as relações sociais, que têm características multifacetadas e possibilidades de argumentar e avaliar as situações comportamentais muito além do raciocínio binário. A cultura jurídica que privilegia o paradigma ganhar-perder não é dirigida para neutralizar o dissenso e limita o espectro de soluções.

De observar, ainda, que muitas vezes a segurança jurídica estabiliza as relações de modo artificial, provocando a insatisfação dos cidadãos contra a lei. É necessário restabelecer o poder da sociedade e das pessoas, para que decidam seus conflitos de uma maneira mais construtiva, garantindo a produção de alternativas aos problemas envolvidos.

No campo do Direito Coletivo do Trabalho, a negociação coletiva entre os protagonistas sociais envolvidos é por muitos o caminho mais adequado e, por tal motivo, eficiente para a solução dos conflitos do trabalho. Como meio de autocomposição nos conflitos trabalhistas, ela deve ser incentivada e estabelecida em campo neutro, sem que as partes tenham receio para expor suas necessidades e possibilidades.

Nossa legislação prestigia tal espécie de negociação, mas o sistema intervencionista brasileiro (lei e poder normativo) limita a manifestação dos conflitos, na medida em que não está voltado para os aspectos intersubjetivos das partes envolvidas, nem às peculiaridades específicas de cada conflito. Ele restringe consideravelmente a atuação dos atores no processo de regulação das relações de trabalho, desnaturando o sentido da negociação coletiva. Assim, a ordem jurídica tradicional não produz, na maioria das vezes, os resultados sociais que dela se espera, por ser voltada a um conceito abstrato de Justiça, que quase sempre se distancia dos interesses e da realidade dos envolvidos no conflito. 
É nessa linha de raciocínio que procuraremos desenvolver uma reflexão sobre o mecanismo complexo do processo de mediação, que, enquanto ferramenta para composição não-judiciária de conflito, é capaz de modificar padrões de conduta e estimular o tratamento do conflito de uma maneira cooperativa, não-adversarial, contribuindo para a lógica da negociação permanente, tão necessária nas relações de trabalho. Ela deve ser utilizada com vistas a dar um tratamento adequado aos conflitos e não apenas como forma de aliviar o Judiciário.

No primeiro capítulo procuraremos definir conflito, os fatores que o influenciam, suas formas de exteriorização e suas especificidades no direito coletivo do trabalho. Discorreremos sobre o excessivo intervencionismo estatal presente em nosso ordenamento jurídico, ponderando em que medida ele não engessa o comportamento dos grupos sociais.

No segundo capítulo, enfocaremos as formas de resolução de conflitos existentes, os fatores e técnicas de negociação utilizadas e a maneira como elas colaboram para o efetivo acesso à Justiça.

No mesmo capítulo procuraremos demonstrar que a promoção da cultura da paz depende da responsabilidade dos atores sociais, que, num conflito, devem aprender a reconhecer e a qualificar a pretensão alheia como hipoteticamente justa.

No tocante aos conflitos coletivos trabalhistas, desenvolveremos uma reflexão sobre o paradoxo existente entre o aparente estímulo à negociação coletiva e o reconhecimento da solução jurisdicional compulsória, já que o Poder normativo ainda é o meio utilizado para tornar certo o conflito coletivo do trabalho.

Analisaremos, ainda, a crescente atenção que o direito processual tem dado aos mecanismos autocompositivos como forma de assegurar uma maior efetividade ao ordenamento jurídico e discutiremos o modo como a mediação poderia ser desenvolvida. O trabalho identifica a autocomposição dentre os meios de solução dos conflitos e sistematiza os mecanismos para sua obtenção.

Destacaremos que o momento é especialmente favorável às iniciativas que buscam desafogar o Poder Judiciário, trazendo à luz mecanismos modernos de solução alternativa de conflitos. A norma programática introduzida pela Emenda Constitucional $\mathrm{n}^{\circ}$ 45 de 2004, ao estatuir que "a todos, no âmbito judicial e administrativo, são assegurados a razoável duração do processo e os meios que garantam a celeridade de sua tramitação" 
(inciso LXXVIII do art. $5^{\circ}$ da Constituição Federal), dá ânimos para perseguir avanços ainda maiores na legislação acerca da mediação.

Ainda no segundo capítulo traçaremos alguns aspectos teóricos da negociação coletiva, refletindo sobre o papel que ela deve desempenhar em nosso sistema jurídico.

No terceiro capítulo daremos destaque ao procedimento da mediação como um dos modos de composição de conflitos, analisando suas técnicas, princípios, procedimentos, distinção com os demais institutos destinados à resolução alternativa dos conflitos.

No quarto capítulo, faremos uma digressão sobre as tentativas de realização da mediação no sistema jurídico brasileiro e analisaremos os Projetos de Lei em andamento, que demonstram a atualidade e relevância do tema. Teceremos, ainda, breve estudo sobre o assunto no direito estrangeiro, tomando como critério alguns países onde ela é fortemente desenvolvida e utilizada (Estados Unidos, Canadá e França) e Argentina que, além de ter seu sistema jurídico pautado na tradição romano-germânica, possui semelhança econômica e política com o Brasil.

Discorreremos sobre a função do mediador na assistência à negociação, nos princípios a serem observados e no Código de Ética dos Mediadores e analisaremos o conjunto de normas jurídicas a respeito. Trataremos da importância e a necessidade de aprimoramento das técnicas da mediação na resolução dos conflitos coletivos do trabalho, como forma de pacificação da sociedade e dos conflitos que envolvem a relação capital/trabalho. Teceremos comentários sobre a mediação realizada nas Delegacias Regionais do Trabalho, no Ministério Público do Trabalho, no que se refere às tentativas de conciliação em dissídios coletivos.

Assim, serão delineados alguns pontos sobre a necessidade objetiva da utilização da mediação com vistas à solução dos conflitos coletivos do trabalho, salientando que a Convenção no 154 da OIT, ratificada pelo Brasil em 29/09/1994 (Decreto 1256/94), ao fomentar o estímulo à negociação coletiva, determina a adoção de medidas extrajudiciais para a composição direta na resolução dos conflitos trabalhistas, que poderão ser tomadas de maneira voluntária pelas partes. ${ }^{12}$

\footnotetext{
${ }^{12}$ ORGANIZAÇÃO INTERNACIONAL DO TRABALHO - OIT. Negociações coletivas. São Paulo: LTr; Brasília: OIT, 1994. p. 136. O artigo $2^{\circ}$ apresenta a seguinte definição:
} 
Analisaremos, dessa maneira, a importância da mediação nos conflitos coletivos do trabalho, não como medida substitutiva do Judiciário, e sim como complemento indispensável, na medida em que transfere às partes a responsabilidade pela manutenção de um diálogo em busca de um acordo, assegurando uma justiça mais real, personalizada e eficaz.

No último capítulo, apresentaremos nossas conclusões.

“Art. $2^{\circ}$. Para os efeitos desta Convenção, o termo 'negociação coletiva' compreende todas as negociações que se realizam entre um empregador, um grupo de empregadores ou uma ou mais organizações de empregadores, de um lado, e uma ou mais organizações de trabalhadores, de outro, para:

a) definir condições de trabalho e termos de emprego; e/ou

b) regular as relações entre empregadores e trabalhadores; e/ou

c) regular as relações entre empregadores ou suas organizações e uma organização de trabalhadores ou organizações de trabalhadores." 


\section{CAPÍTULO 1. CONFLITOS}

O estudo do conflito humano apresenta uma abrangência muito grande, pois inclui todo o espectro das atividades dos seres humanos e dos grupos por eles formados. Neste estudo será focalizado o conflito produzido no panorama de relações sociais intersubjetivas, especialmente no conflito coletivo do trabalho, colocando ênfase nos aspectos que possam contribuir na construção de ferramentas que ajudem a desenvolver um processo fundamentado nos interesses das partes, que facilite $o$ entendimento, a comunicação e o aprendizado.

Não se falará de conflitos em sentido psicológico, muito embora entendemos que é sempre necessário estar atento aos aspectos psicológicos do conflito, uma vez que os interesses latentes e manifestos das partes envolvidas freqüentemente subsidiam os conflitos interpessoais. Ainda, o termo conflito não será utilizado no mesmo sentido de lide judicial, não obstante referida disputa ostente a ocorrência do conflito.

No âmbito da sociologia podem ser identificadas diferentes teorias sobre o conflito. Destacaremos algumas delas, observando-se que por sujeitos de conflito designam-se não apenas pessoas naturais como também organizações, grupos sociais e órgãos do próprio Estado.

Após a Segunda Guerra Mundial estimulou-se a criação de uma série de iniciativas para tentar prevenir o acontecimento de uma outra guerra internacional. Foi criada a Organização das Nações Unidas e começaram a surgir os primeiros estudos relacionados a formas pacíficas de resolução de conflitos. A partir da década de 1970, as novas idéias firmaram uma nova ciência social, ao lado da Sociologia, da Ciência Política e da Antropologia, subdividindo a disciplina em áreas de estudos específicas de onde se popularizou o conceito de conflito social.

Foi no contexto da explosão dos conflitos sociais e, em especial, dos conflitos coletivos do trabalho, que se desenvolveu a chamada Teoria da Integração da Sociedade ${ }^{13}$, que concebe a estrutura social como um sistema funcionalmente integrado,

\footnotetext{
${ }^{13}$ Segundo Norberto Bobbio, Dicionário de Política, tal teoria é defendida por Comte, Spencer, Pareto, Durkhein, e entre os contemporâneos, Talcott Parsons). BOBBIO, Norberto; MATTEUCCI, Nicola; PASQUINO, Gianfranco. 12. ed. Dicionário de política. Brasília: Ed. da UnB, 2004.
} 
mantido em equilíbrio por certos processos padronizados e repetitivos ${ }^{14}$. Segundo tal teoria, a sociedade é compreendida como um sistema social equilibrado e perfeito, cuja estabilidade é obtida consensualmente pela cooperação entre os diversos subsistemas que a compõem $^{15}$. A harmonia e o equilíbrio constituiriam, pois, o estado normal e todo o conflito seria considerado como uma perturbação. Segundo tal teoria, os conflitos são compreendidos tanto em função de causas meta-sociais, ou seja, devem ser encontradas fora da própria sociedade, como também "disfuncionais", na medida em que representam uma força desagregadora do sistema. Nesse contexto, o conflito configura-se como uma patologia social, que deve ser reprimida e eliminada.

Em contraposição a tal teoria, surgem estudos procurando identificar as causas primárias, geradoras dos conflitos sociais, e a importância do conflito no processo de mudança a que estão sujeitas todas as sociedades humanas.

E nesse propósito, a Teoria da Coerção da Sociedade concebe a estrutura social como uma "forma de organização mantida coesa por força e coerção e que se estende constantemente para além dela mesma, no sentido de produzir dentro de si forças que a mantém em um processo contínuo de mudança"16. Assim, em nenhuma sociedade a harmonia e o equilíbrio são normais. O reconhecimento das desarmonias sociais e dos conflitos decorrentes conduz a uma articulação entre os sistemas econômico, político e jurídico, de maneira a criar uma mudança na estrutura normativa, capaz de oferecer respostas às demandas e às controvérsias decorrentes do conflito, possibilitando uma situação de equilíbrio nas relações sociais.

Assim, com base em tal teoria, o conflito não pode ser visto apenas de forma negativa, vez que dele resulta um elemento que conduz a mudanças sociais, políticas e jurídicas e pelo fato de que as sociedades produzem constantemente antagonismos que não nascem casualmente nem podem ser arbitrariarmente eliminados.

\footnotetext{
${ }^{14}$ DAHRENDORF, Ralf. Las classes sociales e su conflicto en la sociedad industrial, cit.

${ }^{15}$ Id. Ibid., p. 148, esclarece que "a teoria integracionalista da sociedade, como exposta na obra de Parsons e de outros funcionalistas-estruturalistas, tem como base um certo número de premissas do seguinte tipo:

(1) Toda sociedade é uma estrutura de elementos relativamente persistente e estável;

(2) Toda sociedade é uma estrutura de elementos bem integrada;

(3) Todo elemento em uma sociedade tem uma função, isto é, contribui para sua manutenção como sistema;

(4) Toda estrutura social em funcionamento é baseada em um consenso entre seus membros sobre valores."

${ }^{16}$ Id. Ibid., p. 146. Referido autor estabelece as seguintes premissas na Teoria Coercitiva da Sociedade:

(1) Toda sociedade está, a cada momento, sujeita a processos de mudança; a mudança social é ubíqua;

(2) Toda sociedade exibe a cada momento dissensão e conflito; o conflito social é ubíquo;

(3) Todo elemento em uma sociedade contribui de certa forma para sua desintegração e mudança;

(4) Toda sociedade é baseada na coerção de alguns de seus membros por outros.
} 
O conflito deixa, então, de ser um fenômeno patológico e passa a ser encarado como um propulsor da democratização nas relações sociais. Ele não representa um mal em si mesmo, vez que possui funções sociais importantes, capazes de proporcionar aos homens o estímulo para promover as mudanças sociais.

Ralf Dahrendorf ${ }^{17}$ observa que toda sociedade histórica conhece conflitos sociais, salientando que os "antagonismos que sistematicamente vão surgindo nas estruturas sociais não se deixam resolver teoricamente no sentido de uma supressão definitiva", o que resulta na necessidade de criação de mecanismos com capacidade de canalizar e controlar os conflitos, de maneira a colocar sua "energia criadora a serviço de um desenvolvimento progressivo das estruturas sociais". Assim, toda sociedade possui um conjunto de mecanismos institucionais que regulamentam o funcionamento das estruturas sociais, sendo que referidas estruturas estão submetidas a uma transformação permanente $^{18}$.

Outro aspecto a ser observado é o de que conflito não significa, necessariamente, defrontação. A incompatibilidade é a principal característica do conflito e muitas vezes determinadas ações provocam efeitos não-desejados. São os chamados efeitos perversos, provocados pelas ações humanas não-intencionais ${ }^{19}$. Assim, pode-se dizer que há efeito perverso quando diferentes indivíduos que buscam um dado objetivo geram um estado de coisas não-buscado e que pode ser indesejável. Trata-se, pois, dos efeitos produzidos que diferem dos objetivos procurados pelas partes em conflitos.

Assim, os estados de desequilíbrio social e de mudança social podem advir não apenas dos conflitos de interesses contraditórios, como também de efeitos perversos gerados por estruturas de interdependência. Explicando melhor, sabemos que uma das fontes dos conflitos sociais reside nas oposições de interesse entre grupos. Mas o efeito perverso que, em condições gerais, leva os membros de um grupo a aceitarem, por exemplo, uma situação contrária ao seu interesse, tem extrema importância na análise do conflito.

Um outro aspecto para a análise do conflito diz respeito à divisão de recursos escassos. É certo que numa sociedade dividida em classes, o conflito é inerente à

\footnotetext{
${ }^{17}$ DAHRENDORF, Ralf. Elementos para uma teoria do conflito social. In: Sociedade e liberdade. Brasília: Ed. da UnB, 1981. p. 141.

${ }^{18}$ Segundo DAHRENDORF, Ralf. Las classes sociales e su conflicto en la sociedad industrial. Madrid: Ediciones Rialp, 1970. p. 164, "As estruturas sociais em contraste com as outras formações não estão, como tais, previamente dadas, não são analisáveis, em princípio, desligadas de sua relação histórica, mas estão submetidas a uma transformação permanente."

${ }^{19}$ BOUDON, Raymond. Efeitos perversos e ordem social. Rio de Janeiro: Zahar, 1979.
} 
estrutura econômica e social. Assim, o conflito é uma das formas de interação entre indivíduos, grupos, organizações e coletividades que implica choques para o acesso e para a distribuição de recursos escassos ${ }^{20}$. Referida escassez pode ocorrer em circunstâncias de absoluta ou relativa ausência de bens.

Como esclarece Antônio Rodrigues de Freitas $^{21}$, a primeira situação pode ocorrer diante de uma ausência absoluta de bens necessários a todos de um grupo. Um evento natural grave, que não pode ser evitado, e que provoca numa comunidade uma ausência total de alimentos é exemplo do que resulta uma situação inevitável de fome a ser alocada entre os membros de tal local. Nesse caso, o problema alocativo consiste na dificuldade de se estabelecerem critérios para a resolução, vez que ninguém preferirá ficar sem alimento e a escolha implica decidir quem vai ou não receber os alimentos. Tais situações não são ordinárias e o problema mais freqüente decorre da ausência relativa de bens, ou seja, ausência de bens em quantidade e/ou qualidade insuficientes de acordo com o que os sujeitos consideram como "necessidades". A escassez deve ser visa, então, numa perspectiva subjetiva do que seria pleno e no sentido da desproporção entre a disponibilidade do bem e a possibilidade de atender as necessidades.

Tomando como marco a análise até então desenvolvida, podemos observar que conflito social e mudança social aparecem simultaneamente. Partindo-se da premissa de que o controle dos conflitos manifestos faz-se por meio do Judiciário, que decide e aplica as sanções que entende devidas, pergunta-se: a solução imposta pelo Judiciário atende as demandas sociais manifestadas? A estrutura e as técnicas disponíveis são suficientes para a resolução dos conflitos sociais? O surgimento de novas formas de luta trabalhista teria se reproduzido sob novas formas de resolução de conflitos e novas práticas de acesso à Justiça?

Constata-se, portanto, que, partindo-se de determinadas análises sociológicas do conflito, podemos melhorar a compreensão dos conflitos sociais, em especial dos conflitos coletivos de trabalho e, conseqüentemente, sistematizar um estudo sobre as formas de sua composição.

\footnotetext{
${ }^{20}$ Conceito obtido em BOBBIO, Norberto; MATTEUCCI, Nicola; PASQUINO, Gianfranco. op. cit., v. 1, p. 225.

${ }^{21}$ FREITAS JÚNIOR, Antonio Rodrigues. op. cit.
} 


\subsection{Funções positivas do conflito}

Procuraremos demonstrar, sem a intenção de oferecer uma listagem exaustiva, algumas funções positivas do conflito tomando de início o conceito de que conflito é o meio pelo qual os problemas podem ser manifestados. O conflito representa o cerne da mudança pessoal e social, capaz de delimitar grupos e, nessa medida, estabelecer uma identidade coletiva e individual ${ }^{22}$.

Com o conflito previnem-se estagnações, na medida em que ele possibilita criar e modificar normas já existentes. Assim, o conflito social pode ser considerado como um mecanismo de adequação de normas e condutas de acordo com as novas condições. Ainda, ao possibilitar a manifestação de interesses díspares, os conflitos podem colaborar para a superação dos antagonismos, além de ser considerado também como um motor para as mudanças, gerador de energia criativa que pode melhorar as situações, colaborar para o fortalecimento de vínculos dos grupos e para reduzir as tensões incipientes ou manifestas.

As manifestações das diferenças interpessoais, ao propiciar uma maior diversidade de pontos de vista, incentiva a renovação das partes envolvidas e do próprio sistema. Nessa medida o conflito se opõe à estagnação do sistema social, vez que exerce uma pressão em favor da inovação e da criatividade. Ainda, a troca de idéias sobre o conflito existente acarreta o melhor conhecimento da posição de cada parte, já que o

\footnotetext{
${ }^{22}$ Coser, Lewis citado por Morton ou ...Discorrendo sobre a funcionalidade do conflito, Morton Deutsch na obra coletiva organizado por André Gomma de Azevedo, Estudos em arbitragem, mediação e negociação. Brasília: Ed. Grupos de Pesquisa, 2004. v. 3, p. 54 destaca as palavras de Lewis A. Coser: Em grupos estruturados sobre laços frouxos e em sociedades abertas, o conflito, que busca a resolução de uma tensão entre antagonistas, provavelmente tem funções integradoras e estabilizantes para o relacionamento. Por permitir uma expressão direta e imediata de reclamações rivais, tais sistemas sociais conseguem reajustar suas estruturas eliminando as fontes de insatisfação. Os inúmeros conflitos experimentados podem servir para eliminar as causas de dissociação e restabelecer a unidade. Esses sistemas fazem uso, por meio da tolerância e da institucionalização do conflito, de um importante mecanismo estabilizante. Além disso, o conflito dentro de um grupo freqüentemente ajuda a revitalizar normas existentes; ou contribui para o surgimento de novas normas. Nesse sentido, o conflito social é um mecanismo de adequação de normas a novas condições. Uma sociedade flexível beneficia-se do conflito por causa desse comportamento, na medida em que ajuda a criar e a modificar normas, assegura sua continuidade sob condições diversas. Tal mecanismo de reajustamento de normas é dificilmente observado em sistemas rígidos: suprimindo o conflito, eles abafam um sinal de aviso geralmente útil, aumentando, assim, o perigo de haver um colapso catastrófico. $O$ conflito interno pode também servir como um meio para averiguar a força relativa dos interesses antagônicos dentro da estrutura, e a partir disso constituir um mecanismo para a manutenção ou contínuo reajuste da balança de poder. Na medida em que a explosão de um conflito indica a rejeição de uma acomodação anterior entre as partes, uma vez que o respectivo poder dos contendores tenha sido averiguado no conflito, um novo equilíbrio pode ser estabelecido e o relacionamento pode prosseguir sobre essa nova base.
} 
diálogo obriga cada uma delas a fundamentar e a sustentar os argumentos em que se apóiam.

Não podemos achar que os conflitos trazem apenas aspectos positivos. Um dos aspectos negativos consiste no fato de que toda sociedade tem limites para tolerar um conflito. Ainda, o conflito corrói tempo e energia, que poderiam ser utilizados para outras soluções mais úteis; ao perder muito tempo com um conflito, pode-se impedir de solucionar exigências básicas, diminuindo, como exemplo, a produtividade industrial num conflito específico. Assim, diante de conflito manifesto, é essencial conservar um nível de estabilidade, para não se perder tempo nem energia para desenvolver outras atividades úteis.

\subsection{Fatores que influenciam os conflitos}

Procuraremos no presente tópico oferecer elementos para uma abordagem sócio-psicológica do conflito, já que a compreensão de certos mecanismos psicológicos pode dar à atuação jurídica um sentido de desenvolvimento cultural e social. A proposta é estudar o perfil dos envolvidos no litígio para, posteriormente, e em capítulo específico, discorrer sobre a importância do estudo dos diversos mecanismos facilitadores para a obtenção da solução do conflito, em especial da mediação.

É fácil observar que os seres humanos vivenciam conflitos ao longo de suas vidas, que, necessariamente, não são combates. Para a psicologia moderna, o conflito é inerente à própria vida, consolidando um mecanismo que permite a evolução da espécie humana, para reconhecer suas fraquezas e melhorá-las. Assim, o conflito pode trazer benefícios para a sociedade por proporcionar mudanças muitas vezes positivas e a sua neutralização, além de não ser possível, muitas vezes não é viável. Assim, é necessário compreender o conflito sem a utopia de neutralizá-lo, pois sua compreensão é a única forma para lidar com essa realidade, já que o conflito é parte integrante da existência humana.

Dentro desta perspectiva, o conflito pode ser visto como uma oportunidade de reflexão sobre a relação da qual se originou, possibilitando, inclusive, o estabelecimento de um novo relacionamento entre as partes envolvidas. 
O significado de conflito abarca também a idéia de um desacordo agudo e de oposição de interesses e idéias. Num conceito mais restritivo, o conflito pode ser considerado como uma relação entre partes, onde ambas procuram a obtenção de objetivos que são, podem ser ou parecem ser para alguma delas, incompatíveis. Ou seja, uma percebida divergência de interesses ou uma crença de que as aspirações das partes não podem lograr-se simultaneamente.

Para Vezzula ${ }^{23}$, o conflito pode ser manifesto ou oculto. O primeiro manifesta-se de maneira explícita e o segundo é implícito, oculto. No conceito de Folberg e Taylor ${ }^{24}$, conflito consistiria em "um conjunto de propósitos, métodos ou condutas divergentes, que estão presentes no cotidiano de todas as pessoas, tanto nas relações interpessoais quanto organizacionais". Assim, o conflito resulta da percepção de divergência de interesses e para compreendê-lo é necessário delimitar a sua causa.

Normalmente, o fato ensejador do conflito $^{25}$ é a mudança, ou seja, a alteração de algum elemento de um sistema social específico. Conflito e mudança são inseparáveis; e para compreender melhor um conflito é necessário examinar sua correlação com a mudança.

Segundo Fioreli ${ }^{26}$, os elementos da mudança podem ser: 1. bens, compreendendo patrimônio, direitos, haveres pessoais; 2 . princípios, valores e crenças de qualquer natureza, inclusive políticas, religiosas, científicas; 3. poder, em suas diferentes acepções; 4. relacionamentos interpessoais. As características das mudanças são determinantes nas naturezas dos conflitos. A partir do momento em que os conflitantes se envolvem com as alterações ocasionadas pela mudança, suas expectativas e idealizações a respeito das conseqüências e resultados podem distanciar-se das reais possibilidades de obtê-los.

\footnotetext{
${ }^{23}$ VEZZULA, J. Teoria e prática da mediação. Florianópolis: IMAB, 2001. p. 24. Referido autor entende que “...o conflito consiste em assumir posições que entram em oposição aos desejos dos outros, que envolve uma luta pelo poder, e que sua expressão pode ser explícita ou oculta atrás de uma posição ou discurso encobridor".

${ }^{24}$ FOLBERG, J., TAYLOR, A. Mediación: resolución de conflictos sin litigio. Buenos Aires: Noriega, 1984.

${ }^{25}$ Nesse sentido, a obra de FIORELLI, José Osmir; MALHADAS JÚNIOR, Marcos Júlio Olivé; MORAES, Daniel Lopes de. Psicologia na mediação: inovando a gestão de conflitos interpessoais e organizacionais. São Paulo: LTr, 2004. p. 15, afirma que "Mudança é toda e qualquer modificação da realidade. Não há conflito sem mudança (...). A mudança, ou a perspectiva dela, conduz ao conflito (ainda que nem toda mudança ocasione um conflito). Ela é a causa raiz de todos os conflitos familiares, organizacionais, societários, comunitários, internacionais etc. Quando algo ou alguém intervém em um sistema - que pode ser desde um indivíduo até uma sociedade completa - surge uma mudança e, conseqüente a ela, algum tipo de conflito."

${ }^{26}$ FIORELLI, José Osmir; MALHADAS JÚNIOR, Marcos Júlio Olivé; MORAES, Daniel Lopes de. op. cit., p. 16.
} 
Morton Deutsch ${ }^{27}$ afirma que um conflito, independentemente de sua realidade, decorre das seguintes questões, podendo ser entre uma ou entre várias delas: 1 . Controle sobre recursos, como espaço, dinheiro, propriedade, poder, prestígios e outros que podem ser vistos como impartilháveis ou insatisfatórios; 2. Preferências e incômodos - conflitos podem surgir quando as atividades ou as preferências de uma parte atrita-se com as preferências da outra. A questão é se uma parte pode exercer um direito na medida em que cria um distúrbio ou incômodo para o outro; 3. Valores - não é a diferença de valores que conduz ao conflito, mas a tentativa de que tal valor domine ou seja aplicado universalmente, inclusive por aqueles que detêm diferentes valores; 4. Crenças - é a questão da percepção de cada parte.

Segundo Bernard Mayer ${ }^{28}$, os conflitos são naturais e inevitáveis e para lidarmos com ele é necessário entender as ferramentas que dispomos para podermos separar os sentimentos complexos que envolvem um conflito. A natureza do conflito é tridimensional: percepção, emoção e comportamento e isso importa que todas essas características sejam tratadas num processo disponibilizado para a sua administração. Segundo o autor, percepção é o conflito gerado por aquilo que acreditamos ser nossa necessidade, interesses e valores que não estão de acordo com os de outra pessoa. $\mathrm{O}$ aspecto emocional impede enxergar o conflito de maneira racional, para sua verdadeira razão. Muitas vezes os interesses são iguais, mas o lado emocional dificulta essa percepção.

O comportamental diz respeito à forma como exteriorizamos e expressamos nossos desejos e sentimentos, que muitas vezes pode ser de forma inadequada, destrutiva. Conclui o autor que para lidarmos com um determinado conflito é importante entender as atitudes, sentimentos, valores, crenças das pessoas ou grupos envolvidos na questão.

Um verdadeiro processo de conflito caracteriza-se pelo conjunto de múltiplas interações entre as partes, que pode, inclusive, ir se agravando gradativamente ou sendo amenizado com o passar do tempo. A maneira como "sentimos" o conflito terá uma grande influência na nossa postura e abordagem para lidar com ele. E para lidarmos com o conflito de uma maneira produtiva, devemos entender sua natureza e suas raízes,

\footnotetext{
${ }^{27}$ Deutsch, Morton - AZEVEDO, André Gomma (Org.). op. cit., p. 39-40.

${ }^{28}$ MAYER, Bernard. The dynamics of conflitct resolution: a practticioner's guide. San Francisco: JosseyBass, 2000. p. 4 et seq.
} 
possibilitando-se, com isso, a compreensão dos motivos relacionados ao comportamento dos participantes.

Ainda, o conflito pode ocorrer em um contexto cooperativo ou competitivo, e os processos de resolução de conflito mais prováveis de aparecer serão fortemente influenciados por esse contexto. Quando bem gerenciado, o conflito resultará positivo, já que ele é capaz de desencadear mudanças para novos aprendizados. O importante é que ele seja gerenciado por meio do gerenciamento das mudanças, o que inclui, principalmente, mudança na própria cultura daqueles que operam com o direito.

Dificilmente os conflitos que se instalam nas relações interpessoais demonstram-se de forma específica e manifesta. Como observa Fiorelli ${ }^{29}$, a idéia de coconstrução do conflito conduz à concepção de gerenciamento ou condução do conflito, cuja forma dependerá da maneira como ocorrem as interações entre as partes. Saber identificar os elementos que envolvem o conflito é muito importante para se conferir uma condução adequada ao problema. As expectativas dos envolvidos, tanto as decorrentes das experiências anteriores das partes quanto as associadas ao relacionamento (relações entre empresas e empregados, entre sindicatos patronais e de empregados, por exemplo), a comunicação e a percepção de justiça são alguns dos fatores que influenciam no processo de conflito. E sobre elas passaremos a nos ocupar nos tópicos seguintes.

\subsubsection{Expectativa dos envolvidos}

A possibilidade de êxito em determinada questão faz com que as partes envolvidas num conflito desenvolvam expectativas que podem decorrer de uma série de fatores, como: positivas experiências anteriores, observação de resultados obtidos com outras pessoas ou grupos, publicidade acerca de casos semelhantes e outros.

Isso pode causar falsas crenças (positivas ou negativas) sobre eventuais possibilidades de sucesso ou de desenvolvimento dos acontecimentos. Por outro lado, tais crenças podem contribuir para despertar a motivação das pessoas para a obtenção dos

\footnotetext{
${ }^{29}$ FIORELLI, José Osmir; MALHADAS JÚNIOR, Marcos Júlio Olivé; MORAES, Daniel Lopes de. op. cit., p. 17.
} 
benefícios perseguidos. Fioreli ${ }^{30}$ acrescenta que a teoria da expectativa sustenta que os seres humanos têm mais motivação quando acreditam na recompensa decorrente do esforço. Assim, as expectativas favoráveis a respeito de um acontecimento futuro apresentam importantes efeitos psicológicos, o que influencia na possibilidade de uma parte não se envolver num conflito.

$\mathrm{Na}$ área de relações do trabalho, a expectativa vincula-se também com as aptidões. Ou seja, as pessoas possuem expectativas mais favoráveis nas atividades em que possuam aptidão natural ou mais desenvolvida e, por tal motivo, procuram exercer tarefas que as deixem mais confortáveis e confiantes ${ }^{31}$. Eventual mudança que as retirem de suas atividades possibilita o aparecimento de expectativas desfavoráveis, possibilitando o aparecimento de conflitos exatamente para se evitar as tais mudanças.

A percepção da existência de um risco pode decorrer de negativas experiências anteriores entre as partes, crenças inadequadas, ou esquemas rígidos de pensamento, podendo exercer grande influência nas expectativas das partes. A harmonia entre as partes dependerá de uma mudança desse tipo de percepção. Por outro lado, a percepção de probabilidade de êxito em determinada questão pode aumentar a perspectiva de sucesso e, conseqüentemente, despertar a motivação para se adentrar num jogo conflitivo. Seria o caso, por exemplo, de obtenção de sentenças favoráveis para determinados grupos ou pessoas da mesma empresa, que acabam motivando os colegas do mesmo trabalho.

Os seres humanos colocam expectativas, ainda que inconscientes, em cada uma de suas relações, e em todos os relacionamentos existe um compromisso psicológico fundamentado exatamente nas expectativas que cada um tem com os demais.

\footnotetext{
${ }^{30}$ FIORELLI, José Osmir; MALHADAS JÚNIOR, Marcos Júlio Olivé. Psicologia nas relações do trabalho: uma nova visão para advogados, juízes do trabalho, administradores e psicólogos. São Paulo: LTr, 2003. p. 206.

${ }^{31}$ Id. Ibid., p. 208, onde descreve interessante paralelo entre expectativa e aptidão: “A combinação de expectativa com aptidão serviria como um elemento modulador de todos os fatores de motivação apresentados, o que pode sugerir reflexões como as relacionadas a seguir:

a. pessoas com expectativas elevadas tendem a motivar-se para assumir os riscos naturais das mudanças;

b. expectativas limitadas conduzem o indivíduo à estabilização em torno da realização de necessidades básicas, fixando-se nas tarefas para as quais possui maior aptidão;

c. limitações da organização de trabalho em oferecer novas possibilidades para profissionais com elevadas expectativas podem conduzir a um aumento indesejado na rotatividade dessas pessoas, porque não encontram formas de enriquecimento da tarefa, para dar vazão a seu potencial."
} 
Tal contrato psicológico ${ }^{32}$ pode ocorrer entre duas pessoas ou entre grupos (equipes de trabalho, grupos representados por sindicatos, por exemplo).

A violação destes contratos tácitos constitui uma importante fonte de conflitos, assim como também um elemento perturbador em uma situação conflitiva prévia. Sua violação também é, por definição, uma violação da confiança, porque a confiança mútua está implícita em qualquer contrato.

Note-se que as expectativas das pessoas transformam-se, dinamicamente, por diversos fatores, como: necessidades pessoais, aprendizado com o meio, legislação aplicável, entre outros. Assim, qualquer relacionamento exige uma constante renegociação, sendo que as partes que vivem em situação de possibilidade de conflito devem sempre estar atentas às diferenças e expectativas do outro lado. A observação de todos esses fatos exerce um importante papel no processo conflituoso.

\subsubsection{Percepção de justiça}

A percepção tem grande influência sobre o comportamento dos seres humanos, já que o modo pelo qual olhamos para os fatos determina a maneira em que agiremos. A percepção de qualquer ato é determinada tanto pela visão do ato em si, como pela visão do contexto no qual o ato ocorre.

Esta percepção tanto pode gerar expectativas falsas sobre as possibilidades de sucesso num conflito, quanto pode contribuir para despertar a motivação das pessoas para a obtenção dos benefícios perseguidos. Ela representa também a crença de que os esforços das partes receberão justa recompensa. A questão é bastante complexa, pois envolve conceitos de justiça, comparação com a outra parte, valor do esforço, da ação, da ilegitimidade da outra parte.

Os contextos dos atos sociais são freqüentemente despercebidos de imediato e muitas vezes não são tão claros, o que favorece o aparecimento de algumas tendências na percepção sobre as ações num determinado conflito. Na maioria das vezes,

\footnotetext{
${ }^{32}$ Fiorelli esclarece que "todo relacionamento contém, implicitamente, um contrato psicológico, baseado nas expectativas tácitas e inconscientes que cada pessoa tem a respeito das demais nele envolvidas (...) A idéia de um contrato psicológico denota que há um conjunto não explícito de expectativas atuando em todos os momentos e entre todos os participantes de um dado relacionamento, por exemplo, em uma família ou Organização: trata-se de um conjunto de expectativas comportamentais de todos os envolvidos".
} 
as pessoas são motivadas a deter uma visão favorável sobre si mesmas, não se colocando, nem achando como legítima, a visão da parte contrária. Se cada parte de um conflito tem a vocação de perceber seus próprios motivos e comportamentos como mais legítimos e benevolentes que os da outra parte, é evidente que o conflito terá um expressivo crescimento.

Ainda, a percepção enviesada da legitimação, do "justo", "do valor do esforço", estimula sobremaneira o conflito, dificultando eventual resolução harmônica. Todo o conflito apresenta a contrariedade entre os objetivos que cada parte persegue. São as chamadas posições assumidas e perseguidas pelas partes em conflito. Os envolvidos no conflito possuem, normalmente, a acirrada manutenção de determinada posição. Roger Fischer e William Ury, na obra Como Chegar ao Sim, que narra conclusões obtidas no Projeto de Negociação realizado pela Faculdade de Direito da Universidade de Harvard, esclarece que

a barganha de posições cria estímulos que paralisam a resolução. $\mathrm{Na}$ barganha posicional, você procura aumentar a probabilidade de que qualquer acordo atingido lhe seja favorável, começando numa posição extremada, aferrando-se obstinadamente a ela, iludindo a outra parte quanto a suas verdadeiras opiniões e fazendo pequenas concessões, apenas na medida necessária, para manter a negociação em andamento.

Normalmente, nos conflitos levados ao Poder Judiciário, as partes supervalorizam suas próprias posições para, a seguir, amenizar suas diferenças. Tal sistema não é o mais adequado para a obtenção de um acordo de vontades, pois a parte que superestima sua posição tende a provocar na outra parte uma sensação de inferioridade e injustiça.

Ocorre que por trás dessas posições as partes são portadoras de necessidades, desejos e valores, que a literatura especializada em ADRs (Alternative Dispute Reslution) passou a chamar de interesses. Como veremos adiante, as noções de interesse e posição aparecem nos estudos de negociação e são especialmente empregadas por Fisher e Ury.

A análise dos interesses reais e da posição formal dos envolvidos nos conflitos é importante para que se obtenha uma alternativa mais razoável e adequada à solução de um impasse, favorecendo a realização da Justiça. A administração das 
mudanças permite a produção de transformações na estrutura de situações passíveis de conflito.

\subsubsection{Comunicação}

A falta de comunicação é uma das principais fontes de conflitos. Quando não existe uma cultura de pacificação e nem canais de comunicação adequados, os desentendimentos tornam-se comuns, principalmente em ambientes de trabalho onde os trabalhadores poderão moldar seu comportamento com base em suas percepções individuais dos fatos, que muitas vezes não correspondem à realidade.

Para resolver um conflito é preciso reconhecê-lo, enfrentá-lo, e, principalmente, considerar que ele não deve ser visto como algo negativo. No ambiente de trabalho, a falta de comunicação não só gera os conflitos como pode aumentá-los, tornando o ambiente insuportável entre os colaboradores em uma empresa. Quando não existem canais de comunicação adequados, quando as pessoas não sabem seus papéis, suas motivações e não conseguem se realizar profissionalmente nas organizações, sempre haverá espaço para um conflito "negativo".

Para Habermas ${ }^{33}$, o desentendimento revela irracionalidade, pois os atores em relação fracassam na sustentação entre si de uma ou mais das condições de validade da ação comunicativa (inteligibilidade, verdade, credibilidade e retidão normativa). A essa situação, ele denomina "patologias ou distorções sistemáticas da comunicação" e recomenda aos interlocutores que interrompam a tematização e alcancem um consenso quanto às condições de validade, ajustando entre si a que esteja falhando. Percebe-se, pois, que a ação comunicativa representa, em termos políticos, um pressuposto da democracia, por se realizar não fora, mas dentro da tensão entre o entendimento e o desentendimento, sendo o desentendimento um fator constitutivo da relação, e o entendimento a sua condição de racionalidade.

\footnotetext{
${ }^{33}$ HABERMAS, Jürgen. Teoría de la acción comunicativa. 4. ed. Madrid: Taurus, 2003.
} 


\subsection{Conflito e poder}

As diferenças de poder em uma relação social podem provocar conflitos, em virtude da possibilidade de repressão da parte mais forte pela parte mais fraca. Para a análise de tal aspecto numa relação conflitiva, necessário apresentar alguns esclarecimentos no tocante ao conceito de poder, a forma como ele se manifesta e as conseqüências que dele decorrem.

O Dicionário de Política de Norberto Bobbio ${ }^{34}$ define que Poder, em seu significado mais geral, significa a capacidade ou a possibilidade de agir, de produzir efeitos. Já no sentido mais específico, relacionado à vida do homem em sociedade, o conceito de Poder pode ir desde a capacidade geral de agir, até a capacidade de determinar ou impor a própria vontade ao comportamento de outras pessoas. Mais adiante acrescenta que para a definição de Poder "não basta especificar a pessoa ou o grupo que a ele está sujeito: ocorre determinar também a esfera de atividade à qual o Poder se refere ou a esfera do Poder". ${ }^{35}$

Para Max Weber, os conflitos sociais compõem um aspecto importante nas sociedades, reconhecendo que a dimensão econômica e o poder são elementos centrais no processo de estratificação social. Segundo o autor a estratificação também é dependente da reputação social e do prestígio, e do poder político, que forma a base de partidos políticos e grupos de interesse. O poder não é eminentemente derivado das condições de domínio (econômico), mas sim é derivado de uma série de processos que resultam em sua legitimação e significa toda a probabilidade de impor a própria vontade numa relação social, mesmo contra resistências, seja qual for o fundamento dessa probabilidade ${ }^{36}$. Conflito, assim, pode ocorrer dentro de uma mesma classe social. Num conflito, as partes podem exercitar o poder por meio de um diálogo social, buscando resolver as divergências e chegar a um acordo.

Pelas características acima narradas, concluímos que a definição de conflito é bastante ampla e envolve diversas possibilidades. Ele pode ser entendido como

\footnotetext{
${ }^{34}$ BOBBIO, Norberto; MATTEUCCI, Nicola; PASQUINO, Gianfranco. op. cit., v. 2, p. 933.

${ }^{35}$ Bobbio exemplifica a definição dizendo que "O Poder do médico diz respeito à saúde; o do professor, à aprendizagem do saber; o empregador influencia o comportamento dos empregados sobretudo na esfera econômica e na atividade profissional (...)” Id. Ibid., p. 934.

${ }^{36}$ WEBER, Max. Economia e sociedade. 3. ed. Trad. Régis Barbosa e Karen Elsabe Barbosa. 5. ed. Brasília: Ed. da UnB, 1994. v. 1, p. 34.
} 
uma situação onde elementos incongruentes direcionam a oposição de direitos ou de pretensões ou numa pretensão resistida pela outra parte. Pode decorrer também de um problema alocativo, incidente sobre bens escassos, de natureza material ou não, ou sobre obrigações do outro que se julgam necessárias. A ausência da mesma percepção de justiça também caracteriza um conflito e mesmo um comportamento antagônico, ainda que não intencional, também pode caracterizar um conflito. Muitas vezes os conflitos não são manifestos, recíprocos e podem nem ser percebidos pelo outro.

Assim, o conceito de conflito abrange também a idéia de um desacordo agudo e de oposição de interesses e idéias e, num conceito mais restritivo, o conflito pode ser considerado como uma relação entre partes, onde ambas procuram a obtenção de objetivos que são, podem ser ou parecem ser para alguma delas, incompatíveis. Ou seja, uma percebida divergência de interesses ou uma crença de que as aspirações das partes não podem lograr-se simultaneamente.

O conflito de trabalho, considerado de maneira genérica, refere-se a todos os antagonismos surgidos nas relações de trabalho. Distinguem-se, basicamente, em individuais e coletivos, sendo que os primeiros têm origem no contrato de trabalho e se produzem entre um trabalhador ou um grupo de trabalhadores e a empresa. O conflito coletivo de trabalho, como veremos adiante de maneira mais detalhada, abrange um grupo de trabalhadores e uma ou várias empresas, referindo-se sempre aos interesses gerais do grupo.

\subsection{Conflitos coletivos do trabalho}

Os conflitos decorrentes do trabalho surgiram das históricas lutas operárias, relacionadas ao processo de industrialização desenvolvido a partir do século XVIII na Europa e nos Estados Unidos, em busca de condições dignas de trabalho, o que permitiu agrupar os trabalhadores e reconhecer suas características comuns.

A Revolução Industrial, como movimento social e econômico de produção e de oferecimento de emprego em massa, provocou êxodo rural que desencadeou diversos problemas sociais nas relações de trabalho, como: exigências de melhores salários e condições de segurança, reconhecimento de descansos semanais remunerados, férias anuais e outros. Assim, a concentração dos meios de produção, o baixo nível de vida da 
população operária e a abstenção do Estado ante essa nova situação econômica e social constituíram o germe para o desenvolvimento do Direito do Trabalho, que surgiu destinado a funcionar como um conjunto de regras jurídicas de natureza tutelar e compensatória visando permitir a realização do fundamento moral que o informa.

A partir de tal marco, advieram os conflitos coletivos de trabalho, onde trabalhadores e empregadores passaram a buscar, por meio de seus sindicatos, a melhor forma para a composição de seus interesses. Assim, historicamente, o surgimento dos sindicatos e a possibilidade da livre associação proporcionou uma grande conquista da classe operária e, atualmente, a representação sindical ainda possui extrema importância na organização dos trabalhadores e na possibilidade de avanço na busca da democracia e do efetivo equilíbrio social e econômico ${ }^{37}$.

São diversas as razões que levam aos conflitos sociais do trabalho. Podemos enumerá-las, sem a intenção de oferecer uma listagem exaustiva: quando uma parte lesa o direito da outra; quando as partes entendem que é necessário mudar as condições de trabalho (as existentes ou as convencionadas); a imensa diferença entre o capital e o trabalho numa relação de oposição, não de colaboração entre empregados e empregadores; as alterações resultantes da natureza e das injustiças sociais; os desequilíbrios econômicos e financeiros das instituições públicas e privadas.

Otávio Pinto e Silva, ao desenvolver estudo sobre a dinâmica do conflito de trabalho na construção do Direito, ressalta que na sociedade pós-moderna os conflitos coletivos não estão mais associados apenas ao trabalho, e são cada vez mais dirigidos contra o poder e a dominação de forma generalizada. Com isso, amplia-se o conteúdo reivindicatório dos trabalhadores e o conflito precisa ser compreendido por uma perspectiva de mudança da sociedade ${ }^{38}$.

Amauri Mascaro Nascimento ${ }^{39}$ esclarece que o objeto do conflito coletivo é o interesse coletivo, que é marcado pela qualidade das partes, pelo objeto do litígio e pelo elemento intencional "resultante da solidariedade conscientemente sentida $e$ pretendida". O conflito coletivo do trabalho configura-se, pois, como a exteriorização do descontentamento dos trabalhadores com suas condições laborais, que é expressa pela

\footnotetext{
${ }^{37}$ MARTINS, José Celso. Arbitragem, mediação e conflitos coletivos do trabalho. LTr: São Paulo, 2005. p. 18.

${ }^{38}$ SILVA, Otávio Pinto e. A contratação coletiva como fonte de direito do trabalho. São Paulo: LTr, 1998. p. 85.

${ }^{39}$ NASCIMENTO, Amauri Mascaro. Conflitos coletivos de trabalho. São Paulo: Saraiva, 1978. p. 11.
} 
ruptura do modelo jurídico, provocando a crise na relação coletiva ${ }^{40}$. Para o referido autor, o conflito coletivo tem um fim normativo e representa "o epílogo de uma tensão que implicará o começo de um procedimento genético-jurídico, explicado como movimento dialético" ${ }^{\text {41. }}$.

Américo Plá Rodrigues ${ }^{42}$ entende que para a noção de conflito coletivo do trabalho, além da necessidade de precisar os termos conflito e trabalho é necessário acrescentar outros componentes, como: 1. a exigência de que o conflito seja entre um ou mais trabalhadores e seu respectivo empregador; e 2. o requisito de que a norma aplicável seja de tipo trabalhista. Mais adiante, referido autor acrescenta que o direito trabalhista não é somente composto pelas leis aprovadas com o rótulo de normas trabalhistas, sendo equivocada a idéia de que os conflitos do trabalho só existem quando se pretende aplicar normas especificamente trabalhistas. Assim, resume seu conceito dizendo que "conflito do trabalho é toda contenda derivada de uma relação trabalhista".

Siqueira Neto ${ }^{43}$ acrescenta que os conflitos coletivos não decorrem da vontade imposta pelos dirigentes sindicais ou líderes carismáticos. Eles surgem em função de um "processo truncado de relação", que pode ser tanto pelo descumprimento dos direitos dos trabalhadores, quanto pela negativa patronal em relação às reivindicações obreiras ou, até mesmo, pelo encaminhamento errado das pretensões por parte dos empregados.

Interessante observar que a doutrina oscila quanto à similitude ou não dos termos conflito, controvérsia, litígio e dissídio. A maioria dos doutrinadores utiliza a expressão conflito para tratar da divergência de interesses. Conflito coletivo é a

\footnotetext{
${ }^{40}$ NASCIMENTO, Amauri Mascaro. op. cit., p. 88. Segundo o autor, o conflito coletivo "é o meio de desenvolvimento de uma ação destinada a obter as normas que faltam para que as relações de trabalho prossigam em termos de um equilíbrio que foi afetado pelo interesse coletivo dos trabalhadores em melhores condições de trabalho. Em sua base está uma problemática de produção de novos modelos jurídicos, de estruturas normativas como unidades integrantes de um conjunto fático-axiológico, que sob a tensão dos fatos e das novas exigências rompem-se, uma vez que vivem em função de uma determinada ordem que nunca se mantém imutável."

${ }^{41}$ Id. Ibid., p. 21.

${ }^{42}$ PLÁ RODRIGUES, Américo. A solução dos conflitos trabalhistas: perspectivas ibero-americanas. Coord. Nestor de Buen). São Paulo: LTr, 1986. p. 7 esclarece que "Para fixar o alcance da expressão conflito do trabalho é necessário precisar os termos que a integram: a)conflito; b) trabalho. A primeira palavra lembra a idéia de contenda, de controvérsia, de oposição de pontos de vista, de confronto entre as partes que efetuam afirmações diferentes ou têm pretensões contrapostas ou incompatíveis. O segundo conceitode trabalho - está vinculado com a concepção de trabalho aceita no Direito do Trabalho. Nem todo trabalho é objeto do Direito Laboral, mas somente aquele que possui certas caracterísitcas."

${ }^{43}$ SIQUEIRA NETO, José Francisco. Contrato coletivo de trabalho: perspectiva de rompimento com a legalidade repressiva. São Paulo: LTr, 1991. p. 119.
} 
divergência entre grupo de trabalhadores de um lado e grupo de empregadores, ou empregador, de outro lado $^{44}$.

Efren Córdova $^{45}$, no entanto, adverte quanto à carência de definições e, referindo-se às discordâncias doutrinárias específicas, conceitua conflito como " a simples divergência de interesses ou discordância na interpretação de uma norma", e controvérsia como a transformação do conflito quando submetido à tutela do Estado.

Alfredo Ruprecht ${ }^{46}$, citando Tissembaum, esclarece que a característica do conflito de trabalho é o contraste de interesses, enquanto a controvérsia do trabalho existe quando se provoca, através do competente processo, o amparo de seu direito ou interesse. Assim, o conflito do trabalho pode existir sem chegar à controvérsia.

Otávio Bueno Magano ${ }^{47}$, ao discorrer sobre os diferentes significados utilizados por alguns doutrinadores, argumenta que a expressão conflito tem o sentido amplo de contraste de interesses, controvérsia significaria o conflito em via de solução e a palavra dissídio, o conflito em via de solução jurisdicional. Referido autor entende que é útil a distinção entre os vocábulos, por permitir particularizar situações diversas na disputa coletiva. Exemplifica que a greve e o lock-out, quando submetidos a processo de mediação, conciliação ou arbitragem, adquirem a feição de controvérsia, e se forem submetidos à decisão judicial adquirem a feição de dissídio.

Entendemos que a distinção acima é a mais apropriada para efeito do presente estudo.

Em função dos sujeitos em conflito, o critério numérico não é decisivo para a classificação dos conflitos de trabalho (individuais ou coletivos), vez que a pluralidade de trabalhadores não é suficiente para dizer que se trata de um conflito coletivo. O conflito coletivo tem um interesse coletivo em discussão, que afeta, indistintamente, a um grupo ou categorias de trabalhadores (de uma empresa, de um setor de atividade ou de um setor profissional). O interesse é sempre coletivo, abstrato, de toda uma categoria.

\footnotetext{
${ }^{44}$ Entre os doutrinadores que utilizam o termo conflito encontramos Américo Plá Rodrigues, Manuel Alonso Olea, Alfredo Ruprechet, Russomano, Cesarino Junior, Amauri Mascaro Nascimento.

${ }^{45}$ CÓRDOBA, Éfren. As relações coletivas do trabalho na América Latina. São Paulo: LTr, 1985. p. 215216.

${ }^{46}$ RUPRECHT, Alfredo. Conflitos coletivos de trabalho. Trad. José Luiz Ferreira Prunes. São Paulo: LTr, 1979. p. 15.

${ }^{47}$ MAGANO, Octavio Bueno. Manual de direito do trabalho: direito coletivo do trabalho. 2. tir. São Paulo: LTr, 1986. v. 3, p. 180.
} 
A classificação de Américo Plá Rodrigues ${ }^{48}$ considera os seguintes critérios para a diferenciação:

a. Critério subjetivo: de acordo com o número de sujeitos, o conflito pode ser individual ou coletivo;

b. Critério objetivo: de acordo com a norma que se leva em conta. Se a discussão decorre do contrato individual do trabalho, o conflito é individual. Se decorre de um instrumento normativo (aplicação ou modificação), o conflito é coletivo;

c. Critério fundamental: decorre do interesse em jogo. Se o interesse for de uma ou mais pessoas determinadas, estaremos diante de um conflito individual. Se o interesse for abstrato ou de toda uma categoria, o conflito é coletivo.

Este último critério é o que mais diferencia os conflitos individuais dos conflitos coletivos, vez que o interesse em jogo nos conflitos coletivos é sempre considerado uti universi. As partes que participam de um mesmo ramo de produção (empregados e empregadores) possuem, além dos interesses concretos e individuais de cada um, interesses idênticos, comuns a todos, dos quais são portadores enquanto membros da categoria ${ }^{49}$.

Conclui-se, pois, que o conflito coletivo reúne as seguintes características: 1. expressão de um conflito real e atual; 2. em relação a uma determinada categoria, versa sobre a criação, modificação, interpretação ou aplicação de normas; 3 . afeta o grupo de trabalhadores como representantes de uma comunidade de interesses e não apenas como a soma material de indivíduos; interessam à categoria como um todo (empregados e empregadores considerados), de maneira abstrata e indeterminada.

\subsubsection{Tipos de conflitos coletivos}

Distinção clássica adotada pelos doutrinadores distingue os conflitos coletivos do trabalho em jurídicos e econômicos. Tal classificação teve origem nos países

\footnotetext{
${ }^{48}$ PLÁ RODRIGUES, Américo. op. cit., p. 10, et. seq.

${ }^{49}$ Conceituaremos categoria como o complexo dos trabalhadores e respectivos empregadores participantes do mesmo ramo de produção e interesses da categoria como o interesse-tipo, considerado abstratamente, dos membros da categoria.
} 
germânicos, como critério de determinação da jurisdição, em face da divisão de competência dos tribunais do trabalho e dos organismos de conciliação e arbitragem ${ }^{50}$.

Os primeiros, também chamados de conflitos de direito, têm por finalidade a interpretação ou aplicação de norma já positivada (lei, regulamento da empresa ou cláusula normativa); supõem uma fonte anterior e, quando submetidos ao Poder Judiciário, são comumente chamados de dissídios coletivos de natureza jurídica.

Já os conflitos econômicos ou de interesses não se relacionam com os direitos preexistentes. Eles objetivam a modificação ou elaboração de novas normas que assegurem novas condições de trabalho e produzem-se por ocasião das reivindicações de uma categoria profissional. Na linguagem cotidiana são chamados de dissídios coletivos de natureza econômica e se caracterizam por visarem a novas condições econômicas, geralmente melhoria de salários. Para Arion Romita ${ }^{51}$, é nesse tipo de conflito que aparece o poder normativo da Justiça do Trabalho. O Tribunal na verdade participa da natureza do conflito e profere decisão que a um só tempo é sentença e lei.

Para Américo Plá Rodrigues ${ }^{52}$, os conflitos de direito devem ser julgados pelo Poder Judiciário e os conflitos de interesse "não podem ser decididos secundum legem, mas sim com critérios de eqüidade e justiça que exigem um amplo conhecimento do meio econômico e trabalhista ao qual se referem".

Não obstante a classificação predominante na doutrina diferencie os conflitos coletivos em jurídicos e econômicos, há outras classificações, que variam de acordo com o critério adotado pelo doutrinador. Como exemplo, Russomano ${ }^{53}$ classifica os conflitos de trabalho próprios, em contraposição aos impróprios ${ }^{54}$; os conflitos intersindicais não-coletivos, que são aqueles que afetam o sindicato como pessoa jurídica e

\footnotetext{
${ }^{50}$ ROMITA, Arion Sayão. Equidade e dissídios coletivos. Rio de Janeiro: Ed. Brasília, 1976. p. 123. O autor esclarece que "a competência dos tribunais do trabalho abrangia todas as demandas jurídicas;os órgãos de conciliação intervinham nos conflitos econômicos".

${ }^{51}$ ROMITA, Arion Sayão. op. cit., p. 124.

${ }^{52}$ PLÁ RODRIGUES, Américo. op. cit., p. 12.

${ }^{53}$ RUSSOMANO, Mozart Victor. Conflitos coletivos de trabalho. São Paulo: Ed. Revista dos Tribunais, 1979. p. 10.

${ }^{54}$ Id. Ibid., p. 85, ao definir os conflitos próprios dos impróprios, Russomano observa que: “Os primeiros se apresentam, historicamente, como os conflitos de trabalho mais ostensivos, porque resultam da contraposição a que chegaram, na sociedade moderna, trabalhadores e empresários. Os segundos, embora relativos ao trabalho e dele decorrentes, não pressupõem a oposição de atitudes do trabalhador e do empregador". Américo Plá Rodrigues distingue os conflitos impróprios em: a. Conflitos intersindicais coletivos,que são as controvérsias produzidas entre as próprias organizações profissionais dos trabalhadores (discussão quanto à representatividade de um grupo, por exemplo); b. Conflitos intersindicais nãocoletivos, que são as contendas derivadas das obrigações que os sindicatos assumem em virtude de suas funções institucionais.
} 
não a categoria que ele representa; conflitos intra-sindicais, que decorrem das divergências entre os órgãos da administração do sindicato ou entre estes e os associados e conflitos entre trabalhadores, que são os que ocorrem no trabalho, resultante de tarefas a serem cumpridas em equipe.

Segundo Amauri Mascaro Nascimento ${ }^{55}$, os conflitos, segundo o prisma judicial, devem ser classificados à luz dos tipos de processos que podem suscitar: processos de reivindicação de novas condições de trabalho e processos de revisão de condições de trabalho pactuadas ou impostas em norma coletiva. Acrescenta que, do ponto de vista processual, o Poder Judiciário reconhece apenas os primeiros, o processo no qual o sindicato de trabalhadores reivindica novas condições de trabalho. Tal fato ocorre porque "quando a matéria gira em torno da aplicação de direito positivo existente ou sua interpretação, o processo não é coletivo, mas individual"

\subsubsection{Elementos do conflito coletivo}

Podemos distinguir quatro elementos essenciais na estrutura dos conflitos coletivos de trabalho: 1. elemento material, que é o meio jurídico ou a matéria jurídica onde as partes travam suas disputas; 2. elemento subjetivo, que representa as partes que contrapõem os interesses em jogo; 3. elemento objetivo, que representa a causa da controvérsia; 4. natureza do interesse comprometido. ${ }^{57}$

\subsubsection{Elemento material}

O elemento material do conflito coletivo de trabalho é a relação jurídica que serve de meio ou base de onde nasce ou se gera o conflito. Com base em tal elemento, é possível a distinção dos conflitos coletivos em duas categorias: conflitos de trabalho próprios e conflitos de trabalho impróprios. Os primeiros são aqueles que se produzem

\footnotetext{
${ }_{55}^{55}$ ASCIMENTO, Amauri Mascaro. op. cit., p. 9 et seq.

${ }^{56}$ Id. Ibid., p. 10. Segundo o autor, "o campo próprio do conflito coletivo é o da elaboração normativa, o do pedido de melhores condiçães para os contratos individuais de trabalho de um grupo, o do julgamento do tribunal escrevendo as palavras que deveriam estar numa convenção coletiva que não foi obtida e, para substituí-la, o do órgão judicial como fonte de direito, o do processo judicial com a função de produzir o direito a ser futuramente aplicado por outros órgãos".

${ }^{57}$ Classificação feita por Alfredo Ruprecht, Conflitos coletivos de trabalho, cit.
} 
entre as partes de uma relação de trabalho ou sujeitos de uma convenção coletiva; os segundos, são os que se dão entre associações profissionais ou entre estas e seus filiados ou até mesmo entre os empregados por causa do trabalho.

Os conflitos intersindicais decorrem de divergências nas relações profissionais de uma mesma categoria - trabalhadores ou empresários - ou entre associações de um ou outro setor, e costumam se dividir em coletivos e não-coletivos. Os primeiros decorrem da questão de representatividade de uma categoria, normalmente de empregados. Nesses casos, não existe um conflito de trabalho, mas a matéria está relacionada às condições de trabalho (não às condições propriamente ditas, mas a questão de quem tem poderes para discuti-las). Os últimos possuem natureza jurídica e estão vinculados às obrigações e direitos preestabelecidos institucionalmente nas organizações sindicais.

Ari Possidonio Beltran ${ }^{58}$, referindo-se ao papel da cidadania, exemplifica que numa greve contra o Estado (não contra o empregador), ou numa greve em protesto contra a morte de motorista/cobrador, morto pela ausência de segurança pública, falta o requisito do elemento objetivo relacionado ao contrato de trabalho e, nesses casos, não podem ser considerados conflitos coletivos de trabalho, já que não estão relacionados à relação de trabalho. $\mathrm{O}$ mesmo não ocorre com a greve de solidariedade que versa, ainda que indiretamente, sobre interesses profissionais ao reforçar a pressão sobre os empregadores, possuindo, assim, conexão com os interesses abstratos relacionados com o trabalho e, tecnicamente, pode ser considerada como conflito coletivo de trabalho.

\subsubsection{Elemento subjetivo}

O elemento subjetivo é composto pelos sujeitos que intervêm no conflito. Wagner Giglio destaca que nos conflitos coletivos discutem-se interesses abstratos de uma categoria composta de número indeterminado de pessoas, enquanto nos conflitos individuais o conflito de interesses é concreto e entre pessoas determinadas ${ }^{59}$.

A intervenção dos sindicatos em tais conflitos é de extrema importância, em razão do prestígio da autonomia privada coletiva, calcada na autotutela coletiva (poder

\footnotetext{
${ }^{58}$ BELTRAN, Ari Possidonio. A autotutela nas relações de trabalho. São Paulo: LTr, 1996. p. 62-64.

${ }^{59}$ GIGLIO, Wagner. Direito processual do trabalho. São Paulo: LTr, 1994. p. 193.
} 
de defesa dos interesses do grupo utilizando-se dos meios de ação pertinentes). Ainda, como corretamente observa Ruprecht ${ }^{60}$, a intervenção do sindicato nos conflitos coletivos é de grande importância e quanto maior o fortalecimento de sua responsabilidade, maior será sua autoridade sobre a declaração formal do conflito.

Os empregados devem ser estar representados pelos sindicatos representativos da respectiva categoria profissional, e, no caso de categorias inorganizadas em sindicatos, a federação, e na falta desta, a confederação terá que assumir a representação ${ }^{61} \mathrm{e}$, necessariamente, toda a responsabilidade sobre o movimento.

\subsubsection{Elemento objetivo}

Elemento objetivo é o motivo ou o objeto do conflito. É nesse aspecto que observamos a diferenciação entre conflitos jurídicos ou de direito e econômicos ou de interesse.

Como já vimos anteriormente, as controvérsias coletivas de direito ou jurídicas baseiam-se em normas preexistentes, enquanto os conflitos econômicos carecem de tais normas ou possuem outros fins. Ocorre que em todo conflito jurídico há sempre um conteúdo econômico e em certas ocasiões torna-se difícil distinguir um do outro. A distinção nesses casos deve levar em conta o fator preponderante do objeto do conflito. Se o interesse predominante é jurídico, estaremos diante de um conflito coletivo de natureza jurídica; se ocorrer o contrário, teremos um conflito econômico ${ }^{62}$.

Segundo Alfredo Ruprechet ${ }^{63}$, a Organização Internacional do Trabalho adota a seguinte classificação:

O conflito jurídico se refere à interpretação ou aplicação de um direito nascido e atual, pouco importa que este tenha sua fonte numa prescrição formal da lei ou em uma disposição de contrato individual ou coletivo; a decisão corresponde, normalmente, a um juiz e em particular ao juiz do trabalho.

O conflito de interesses não versa sobre a interpretação de um direito adquirido, fundado na lei ou no contrato; é uma reivindicação que tende

\footnotetext{
${ }^{60}$ RUPRECHT, Alfredo. op. cit., p. 32, et. seq.

${ }^{61}$ Art. 611 e respectivos parágrafos da CLT.

${ }^{62}$ RUPRECHT, Alfredo. op. cit., p. 42, et seq.

${ }^{63}$ Idem, p. 44.
} 
a modificar um direito existente ou a criar um direito novo; estes conflitos competem, normalmente, ao conciliador ou árbitro.

\subsubsection{Interesse comprometido}

A natureza do interesse é mais um elemento que diferencia os conflitos coletivos de trabalho, que, no caso, é o interesse da categoria. Tal elemento permite-nos analisar as diferenças entre os conflitos coletivos e individuais.

Para Sussekind $^{64}$, o que caracteriza a natureza do conflito é o seu objeto. Se a discussão envolve uma ou várias pessoas e o direito proveniente da relação de emprego a que se vincularam, seja este resultado da lei, de sentença, de contrato coletivo ou individual, haverá um conflito individual. O conflito coletivo ocorre quando a controvérsia tiver por objetivo assegurar às pessoas que pertencem a certo grupo, ou à categoria de trabalhadores, tanto no que diz respeito a novas condições de trabalho, como também em relação à aplicação e interpretação das normas jurídicas vigentes.

A definição e o entendimento do conceito de conflito de trabalho permite-nos chegar à relevância do termo proposto, com vistas a encarar o conflito como meio necessário para a aproximação das partes (empregado e empregador, representados por seus sindicatos), e, conseqüente, permitindo-se um diálogo maior nas relações de trabalho, o que representa um grande salto na busca da pacificação pela mediação.

\subsection{Limites do Judiciário para absorver e decidir os conflitos coletivos do trabalho}

O modo de produção capitalista, norteada pela distribuição desigual de rendas, é fonte permanente de conflitos entre empregados e empregadores. A administração dos conflitos coletivos de trabalho por meio de uma justiça especializada constituiu uma das inovações operadas na estrutura do Estado Moderno, época em que os conflitos de trabalho passaram a ter um espaço próprio de regulação. Tal ambiente foi, na verdade, elaborado com o objetivo de minimizar o potencial desagregador dos conflitos de

\footnotetext{
${ }^{64}$ Sussekind, apud RUPRECHT, Alfredo. op. cit., p. 35 et seq.
} 
trabalho e foi um recurso utilizado pelo Estado para controlar os avanços das conquistas dos movimentos operários.

Assim, a regulação das relações de trabalho no Brasil realizada no Estado Novo, em plena época de autoritarismo, foi feita em nome da manutenção da paz e da ordem social e com base nos seguintes pressupostos: 1. as relações coletivas de trabalho constituíam manifestação da luta de classes e o regime político deveria evitar qualquer manifestação de antagonismo, mediante o estabelecimento da ideologia da paz social; 2. havia grande receio de que os conflitos sociais pudessem afetar a sociedade, o que justificou, dentro dessa filosofia política, o desenvolvimento de minuciosa regulação das condições de trabalho, a fim de tornar desnecessária eventual ação sindical, condicionando os interlocutores sociais a buscarem no Estado a solução dos eventuais conflitos ocorrentes $^{65}$. O modelo de relações coletivas de trabalho da época ${ }^{66}$ tinha como características a supressão da liberdade sindical e do direito de greve; a ausência de autonomia sindical, vez que tais entidades estavam sujeitas ao controle e direcionamento da ação sindical pelo poder público; a instituição de contribuição sindical compulsória; a adoção do conceito de categoria e do princípio de unicidade contratual. Assim, dentro desse contexto, o Estado praticamente anula os mecanismos de autoregulação e autocomposição dos interesses e a Justiça do Trabalho, investida de seu poder normativo, passa a constituir o único canal disponível para a defesa dos interesses dos trabalhadores.

Interessante observar também que o processo de juridificação ${ }^{67}$ das relações de trabalho redundou numa institucionalização progressiva dos direitos sociais e

\footnotetext{
${ }^{65}$ ANTUNES, Ricardo L. C. O que é sindicalismo. São Paulo: Abril Cultural, 1985. p. 58. Segundo o autor, nessa primeira fase, "o Estado varguista procura controlar o movimento operário e sindical trazendo-o para dentro do aparelho de Estado. Uma das primeiras medidas foi a criação do Ministério do Trabalho, em 1930, com o nítido objetivo de elaborar uma política sindical visando conter a classe operária dentro dos limites do Estado e formular uma política de conciliação entre o capital e o trabalho. Não foi outro o objetivo da "Lei de Sindicalização" de 1931 (Decreto 19.770) que, contrariando a liberdade de associação sindical existente durante a Primeira República, criou os pilares do sindicalismo no Brasil'.

${ }^{66}$ Id. Ibid., p. 59. Na apresentação do Decreto 19.770, de 1931, que criou a "Lei de Sindicalização", o primeiro Ministro do Trabalho do Governo Vargas, Lindolfo Collor, fez a seguinte apresentação: “Os sindicatos ou associações de classe serão os pára-choques destas tendências antagônicas. Os salários mínimos, os regimes e as horas de trabalho serão assuntos de sua prerrogativa imediata, sob as vistas cautelosas do Estado."

${ }^{67}$ Entende-se por juridificação o fenômeno de intensa expansão das regras do direito sobre as condutas humanas; as relações sociais são reconstruídas como relações jurídicas, onde o Estado intervencionista determina uma minuciosa disciplina das relações sociais, de acordo com seus objetivos econômicos e sociais. Antonio Rodrigues de Freitas Junior (op. cit., p. 216) esclarece que o fenômeno "na expansão, em proporções geométricas, e na diversificação e sofisticação, dos mecanismos jurídicos pelos quais o poder público passou a interferir em relações sociais, histórica e originalmente concebidas como pertinentes ao domínio do mercado ou da tradição. É necessário atentar que para a circunstância de que esse fenômeno, embora tenha se intensificado no curso da expansão do welfare state europeu, e possa ser visto como um
} 
laborais, mas a forte normatização surgida para proteger os trabalhadores do liberalismo irresponsável da constituição da República, que projetava o futuro brasileiro nos valores ultrapassados do liberalismo europeu do século XIX, perde o sentido diante da atual sociedade organizada e consciente, que enuncia a necessidade de redefinir sua relação com as normas e regras estatais ${ }^{68}$. Os inúmeros questionamentos e críticas sobre o sindicalismo corporativista burocrático $^{69}$ denotam uma aspiração que emerge dos novos modos de organização coletiva dos trabalhadores, que, na verdade, decorrem do conhecimento da capacidade organizativa dos grupos sociais, verdadeiramente oposto ao que inspirou os legisladores da década de 30.

Ocorre que, ao contrário do que se esperava, o fim do Estado Novo não refreou, no direito coletivo de trabalho, os princípios e instituições geradas e proliferadas durante o período corporativista do Governo de Getúlio Vargas, e hoje ainda é possível constatar os resultados produzidos por aquele regime, principalmente no que diz respeito à organização do movimento sindical, ao poder normativo e à contribuição sindical compulsória $^{70}$. Constata-se, assim, que a excessiva atuação do Poder Judiciário, em detrimento de outras formas de composição dos conflitos, é reflexo da política social daquela época, o que contribuiu para o atrofiamento dos mecanismos de autoregulamentação dos conflitos.

subproduto necessário desse último, está presente em toda a experiência jurídica contemporânea. Em síntese, num fenômeno a que alguns autores denominam "colonização", pelo direito, das relações sociais, a juridificação reconstrói as relações sociais anteriormente infensas à regulação jurídica, trazendo-lhe incontáveis e imprevisíveis efeitos colaterais indesejados. Desse modo, retira dos respectivos atores significativa parcela de responsabilidade, no balizamento de seus desejos e expectativas, como sub-produto paradoxal da fixação jurídica - quando não estritamente estatal, judiciária ou legislativa - dos quadrantes formais da responsabilidade. Em outras palavras, pela fixação jurídica da responsabilidade, produz-se em grande medida a 'irresponsabilização' dos atores sociais". Ainda quanto ao tema, interessante consultar as obras SIMITS, Spiros. La giuridificazione dei rapporti di lavoro. DLRI, n. 30, p. 215-276, 1986 e GIUGNI, Gino. Giuridificazione e deregolazione nel diritto del lavoro italiano. In: Lavoro legge: contratti. Bologna: Il Mulino, 1989. p. 317-241.

${ }^{68}$ Interessante destacar a observação de Wilson Ramos Filho, O fim do poder normativo e a arbitragem. São Paulo: LTr, 1999. p. 64, onde o autor menciona o entendimento de Clèmerson Merli Clève que afirma: " $O$ jurídico não existe isoladamente. $O$ seu sentido provém dos conflitos que permeiam toda a sociedade, vinculados às relações de produção. As relações jurídicas não podem ser compreendidas isolada e substantivamente, pois o direito se insere no contexto das relações sociais manifestas pelas condições materiais de existência. Não é 'mero reflexo' nem subordina-se à economia, como quer o esquerdismo ingênuo, mas sua vinculação, ainda que mediata, com o processo produtivo é incontestável, tanto que o direito nunca pode estar mais elevado que a estrutura econômica da sociedade e a evolução da civilização condicionada por essa estrutura”.

${ }^{69} \mathrm{E}$ nesse sentido observamos severas críticas quanto ao modelo de sindicato único por categoria, à contribuição sindical obrigatória e ao Poder Normativo, que foi um instrumento criado para impedir a interlocução direta entre as classes sociais. Amauri Mascar Nascimento, por exemplo, observa que já não mais continuam a valer os pressupostos políticos que inspiraram a organização sindical, encontrando-se "totalmente superadas as idéias em que se baseiam o Estado Novo para sua elaboração".

${ }^{70} \mathrm{O}$ atual sistema apresenta algumas mudanças como: autonomia sindical, reconhecimento da autonomia coletiva, possibilidade de atuação das entidades sindicais, tolerância à greve. 
Não obstante, a sociedade começa a mudar sua relação com o Estado a partir da própria mudança das relações entre as classes sociais que o constituem ${ }^{71}$, o que implica no surgimento de uma nova relação com o direito enquanto poder atuante instituído e, conseqüentemente, com o próprio sentido de justiça. Essa mudança resulta em uma nova mentalidade que abre espaço para uma ampla interrogação sobre o real significado da "livre negociação", dos conceitos de "regulamentação" de direitos e de "solução" dos conflitos de trabalho. Assim, o sentido de justiça torna-se mais real quanto mais a ação sindical confirma sua legitimidade e capacidade de participar dos conflitos, desenvolvendo, com a própria redefinição de negociações, critérios de multiplicidade de orientações e criatividade de soluções.

Mas o poder de negociação adquirido ao longo dos anos pelas organizações sindicais encontra-se limitado pela estrutura do atual sistema jurídico ${ }^{72}$. $\mathrm{O}$ que se percebe, por exemplo, é que muitas negociações coletivas são voltadas para o dissídio coletivo como ponto terminal e inevitável e, nesse caso, a processualística própria da Justiça do Trabalho e a sua capacidade de editar normas (Poder Normativo), de arbitrar compulsoriamente os conflitos e de executar suas decisões, contraria a idéia de uma justiça fundada nas aspirações e na possibilidade de construção de medidas justas pelas próprias partes.

\footnotetext{
${ }^{71}$ Para Maria Célia Paoli, Revista USP, p. 10 "na medida em que se implanta uma reestruturação produtiva que afeta os processos e condições de trabalho e que estes, por sua vez, implicam na mudança conflitiva de sua organização; que modos diversos de contratação sejam exercidos simultaneamente no mercado de trabalho, provocando sua fragmentação e insulando sistemas de gestão e de supervisão de trabalho, cuja relação é constantemente efetuada pelos sindicatos e suas centrais como questões políticas cruciais; que as inovações tecnológicas e organizativas são confrontadas quase pontualmente com o poder das organizações dos trabalhadores nos locais de trabalho; que tudo isso afeta as políticas industriais e econômicas, provocando simultaneamente a formação de todo um mercado de trabalho segmentado, heterogêneo em seus movimentos de inclusão e exclusão, claramente tudo isso muda não só o caráter "clássico" do "pacto" original do Estado com as classes sociais - ou seja, da estrutura e da representação sindical (mudanças estas em grande parte já conhecidas constitucionalmente) - como também mudam as relações entre os trabalhadores organizados, o empresariado e a sociedade”.

${ }^{72}$ José Francisco Siqueira Neto, em sua obra Direito do trabalho \& democracia: apontamento e pareceres. São Paulo: LTr, 1996. p. 141, ao analisar o sistema adotado pelo direito pátrio na solução dos conflitos coletivos, observa que "o sistema brasileiro de solução dos conflitos coletivos de trabalho é realmente balizado pela solução jurisdicional compulsória. Não obstante opiniões favoráveis, não podemos deixar de considerar o paradoxo constitucional existente entre o aparente estímulo à negociação coletiva e o reconhecimento da solução jurisdicional compulsória. Apesar de certo esforço doutrinário no sentido de equacionar o incongruente sistema brasileiro de relações de trabalho, estamos diante de um problema sem solução: ou estimula-se a negociação coletiva com garantias efetivas ao seu exercício, ou estabelece-se a solução jurisdicional compulsória à composição dos conflitos coletivos de interesse. Na segunda hipótese, temos que lamentar e reconhecer que neste ambiente não se tem negociação coletiva e, conseqüentemente, o tema da solução dos conflitos coletivos passa a ser irrelevante, posto que a lógica do sistema intervencionista compulsório sempre falha com a alternativa única de reprimir e eliminar os conflitos, sem qualquer saída negociada".
} 
Assim, nosso sistema jurídico determina que diante do impasse de uma negociação, a principal saída para apaziguar o conflito existente é transformá-lo num conflito jurídico, para que o Estado intervenha. Na visão do Poder Judiciário, o conflito se manifesta como a conseqüência de uma violação das regras de direito, mas o que o direito resolve é a oposição de pretensões jurídicas; ou seja: o direito resolve litígios, que são limitados pelo objeto da demanda. Em outros termos: o litígio é a redução do conflito, "é um momento, um episódio do conflito". ${ }^{73}$ E o Estado, por meio de seu Poder Judiciário, é incapaz, pela própria cultura adversarial informada em nossos cursos jurídicos e pelas regras processuais que delimitam os limites da lide, de resolver satisfatoriamente os litígios.

Explicando melhor, o conflito submetido à ordem judiciária possui, em sua essência, um método formal de solução, com estrutura e regras próprias para o seu regular desenvolvimento. Em nossa cultura jurídica prevalece o entendimento de que as regras jurídicas cumprem a função de assegurar a paz, e é o Poder Judiciário quem tem a função de tratar a violação dessas regras. Mas a existência da norma jurídica não é suficiente para a pacificação social. Quando uma parte atribui a si a titularidade de um direito, podem ocorrer duas situações: a satisfação, que seria o exercício desse direito sem qualquer impedimento, ou a insatisfação, que está relacionado aos obstáculos postos à sua pretensão, sendo que estes podem advir da resistência de outrem ou da própria regulação jurídica, quando esta proíbe a sua satisfação voluntária ${ }^{74}$. Diante do conflito, e sendo almejada sua solução, a jurisdição estatal se apresenta, quando as partes não conseguem uma solução amigável, o único meio disponível para o fim desejado.

Isto faz com que os conflitos sejam encarados como um problema e sejam solucionados pelo Judiciário por meio de uma atuação enérgica, não dando margens ao desenvolvimento de mecanismos necessários ao real entendimento entre as partes.

Observe-se que o sistema Judiciário pátrio, com sua lógica binária, não tem condições de compreender todo o desenrolar do conflito, pois a solução de conflitos dentro da órbita processual-judiciária segue metodologia própria e sempre com base nas repercussões jurídicas que envolvem as situações apresentadas. Assim, a racionalidade sistêmica manifestada pelo Poder Judiciário reduz as partes conflitantes a uma linguagem

\footnotetext{
${ }^{73}$ GRAU, Eros Roberto. O direito posto e o direito pressuposto. São Paulo: Malheiros Ed., 1996. p. 20.

${ }^{74}$ CALMON, Petrônio. Fundamentos da mediação e da conciliação. Rio de Janeiro: Forense, 2007. p. 21. O autor conclui em nota de rodapé que "a pacificação social não é obstacularizada somente pela resistência, mas igualmente quando o próprio Estado impõe limites à plena e espontânea realização do direito."
} 
técnica, que impede qualquer possibilidade de viver e entender a real dimensão do conflito. $^{75}$

O modelo tradicional de jurisdição não resolve a lide sociológica, quando muito resolve a lide processual. Ou seja, trata a conflituosidade social com superficialidade, dirimindo controvérsias e nem sempre resolvendo o próprio conflito.

É fato, ainda, que a estrutura do Poder Judiciário não é dotada de procedimentos investigatórios interessados em delimitar o real interesse das partes envolvidas, muito menos é voltada à manutenção do bom relacionamento das partes, vez que sua preocupação é "resolver" o conflito da forma em que foi proposto. E como já foi dito anteriormente, os conflitos não se eliminam. É necessário lidar produtivamente com eles, desenvolvendo-se estratégias para neutralizar seus efeitos negativos. A expressão resolução de conflitos é associada à idéia do conflito como um fenômeno negativo, que deve ser eliminada. Já o conceito de administração de conflitos reconhece os aspectos positivos e negativos do conflito, bem como a necessidade de convivência com eles. Ou seja, a administração dos conflitos procura desenvolver estratégias para minimizar as

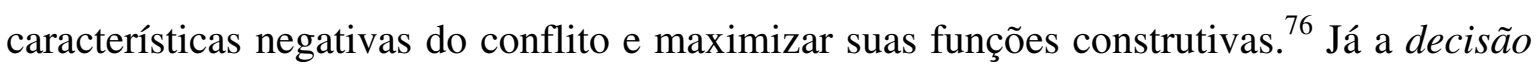
de um conflito pelo Poder Judiciário não significa o seu término, a sua solução. Há somente uma requalificação do conflito, que voltará a se manifestar.

Assim, pela órbita judiciária, o conflito representa um obstáculo para as próprias relações sociais, ao invés de se tornar um indicativo e um dinamizador de mudanças evolutivas. Já os conflitos tratados por meios consensuais de solução possibilitam, como veremos com melhores detalhes, através de métodos utilizados para auxiliar e estimular as partes envolvidas a alcançarem uma solução consensual, a abertura de espaço para uma abordagem mais ampla dos aspectos sócio-psicológicos presentes nos conflitos, contribuindo, na medida em que as partes passam a participar na solução de seus

\footnotetext{
${ }^{75}$ Aurélio Wander Bastos em sua obra Conflitos sociais e limites do Poder Judiciário: subsídio metodológico para a compreensão do procedimento judiciário. Rio de Janeiro: Eldorado, 1975. p. 32, exemplifica que os “conflitos de opiniões, os conflitos de interesse etc, se absorvidos pelo 'sistema' Judiciário, põem em funcionamento mecanismos de correção (técnicas usuais e técnicas dissimuladas), cuja racionalidade sistêmica manifestada nos enunciados normativos reduz as partes conflitantes a certas formalidades processuais e a uma linguagem estritamente técnica, que elimina toda a possibilidade de o Poder Judiciário viver a dimensão total do conflito".

${ }^{76}$ Simmel, G.: Soziologia. Muniche/Leipzig, (1922), in Freyer, Hans: La Sociologia, Ciência de la Realidad, Capítulo sobre Crítica ao Formalismo, Buenos Aires, Ed. Losada (1944), p. 186, apud BASTOS, Aurélio Wander. op. cit., p. 36 salienta que "Só há uma atitude razoável perante o conflito social, embora seja raramente preferida. Mais comum são as que pretendem abafar os conflitos e as que pretendem resolvêlos. Abafá-los significa torná-los mais violentos, resolvê-los significa enganar-se. A atitude mais concreta seria a de os regular; é o caminho da contenção de sua violência."
} 
próprios conflitos, para o regular exercício de cidadania e, conseqüentemente, para o processo de democratização do Estado.

No caso do Direito Sindical, por exemplo, José Francisco Siqueira observa que o marco de legalidade que sempre revestiu essa parte do direito foi o de reprimir sua atuação, inibindo, por meio da utilização do aparato legislativo à sua disposição, qualquer atitude tendente a torná-lo mais autêntico e representativo. E no campo da resolução dos conflitos coletivos, o paternalismo observado pela existência do Poder Normativo da Justiça do Trabalho, desestimula a prática da efetiva negociação, vez que

o cunho ideológico progressivo e natural que decorre do julgamento desse processo, aliado ao compreensível despreparo dos julgadores para analisar casos complexos de organização de trabalho e suas conseqüências, combinado como primado da uniformização de jurisprudência e o longo tempo de decisão processual, redunda em decisões judiciais niveladas por baixo, influenciando negativamente as tratativas diretas e penalizando os sindicatos mobilizados em detrimento dos mais débeis ${ }^{77}$.

Acrescente-se, ainda, que a realidade social é sujeita a um contínuo processo de mutação, enquanto o Poder Judiciário tem sua mutabilidade limitada pelas próprias normas. $\mathrm{Na}$ medida em que este tem como função precípua decidir os conflitos com base no direito substantivo contido no ordenamento jurídico e não de acordo com a realidade que "criou" o conflito, o Poder Judiciário pode funcionar como um redutor da dinamicidade dos conflitos sociais, já que o equilíbrio das relações de conflitos é buscado dentro de sua própria sistemática.

Ou seja, a atual estrutura judiciária não acompanha todas as mudanças que ocorrem na sociedade e segue uma cultura de aplicação uniforme do direito para realidades sociais diferentes. Necessário adaptar o procedimento judiciário trabalhista às novas formas e realidade em que o Direito Coletivo está inserido ${ }^{78}$, não apenas por meio do

\footnotetext{
${ }^{77}$ SIQUEIRA NETO, José Francisco. Contrato coletivo de trabalho: perspectiva de rompimento com a legalidade repressiva, cit., p. 24-25.

${ }^{78}$ Nesse sentido, Ada Pelegrini Grinover, Modernidade do direito processual brasileiro. Revista da Faculdade de Direito da Universidade de São Paulo, São Paulo, v. 88, p. 273-298, jan./dez. 1993, esclarece que o direito processual percorreu três fases distintas: 1. a primeira, de índole técnico-científica; 2. a segunda, eminentemente crítica; 3. a terceira, "em que o processualista torna a dirigir suas preocupações à técnica processual, utilizando-a para revisitar os institutos processuais, a fim de adequá-los à nova realidade, no esforço de edificar um sistema apto a atingir os escopos, não só jurídicos, mas também sociais e políticos da jurisdição. E, ao mesmo tempo, revitalizando e dando impulso, num amplo quadro de política judiciária, aos meio alternativos de solução de litígios".
} 
aperfeiçoamento do serviço público jurisdicional, mas também por meio de estudo sistemático dos mecanismos e técnicas para a obtenção da autocomposição.

Assim, a abordagem do conflito coletivo de trabalho num processo de mediação possibilita não apenas uma análise mais detalhada e real dos aspectos sócioeconômicos que interferem nas relações dos envolvidos, como também o exercício da autonomia e representatividade dos sujeitos coletivos. A administração dos conflitos de trabalho num procedimento de mediação estimula a consciência coletiva, que é a base do movimento sindical e atua de forma educativa, de modo que os sujeitos envolvidos entendam melhor suas aspirações, evitando futuros conflitos ou mantendo o diálogo entre as partes para que possam buscar soluções para conflitos futuros. Necessário restabelecer o poder da sociedade e das pessoas, para que decidam seus conflitos de uma maneira mais construtiva, garantindo a produção de alternativas aos problemas envolvidos: "Menos soluções impostas e mais soluções consensuais - esse parece ser o paradigma de solução de controvérsias. E nesse sentido a mediação é uma das alternativas desenvolvidas em vários países ocidentais"

\footnotetext{
${ }^{79}$ BUITONI, Ademir. A ilusão do normativismo e a mediação. Revista do Advogado, São Paulo, v. 26, n. 87, p. 110 , set. 2006.
} 


\section{CAPÍTULO 2. FORMAS DE COMPOSIÇÃO DOS CONFLITOS COLETIVOS TRABALHISTAS}

\subsection{Meios de soluções para os conflitos coletivos de trabalho}

Como vimos anteriormente, uma das características dos conflitos coletivos de trabalho é o constante estado de tensão que envolve a respectiva relação, decorrente da evidente desigualdade social, econômica e hierárquica entre as partes que deles participam. Não podemos nos esquecer que em razão dos reflexos econômicos e, por vezes, políticos, há também um grande interesse social envolvido.

Segundo Ruprecht ${ }^{80}$, os conflitos de trabalho são, geralmente, de interesses, onde uma das partes causa dano à outra para poder impor suas condições e obter assim a vitória desejada. Mas é impossível manter esse perpétuo estado de luta, o que torna necessário encontrar uma solução adequada para obter a "paz industrial”.

O conflito coletivo se constitui, pela sua própria natureza, em um problema crônico da sociedade. Negar ou inibir tal característica resulta na manipulação da conscientização dos trabalhadores no que diz respeito à luta para melhoria nas condições de trabalho e na limitação da autonomia privada coletiva, que possibilita a regulação das relações de trabalho pelos próprios grupos sociais específicos. Como diz José Francisco Siqueira Neto $^{81}$, aludindo-se a Otto Hahn-Freund, os conflitos de interesse são inevitáveis em qualquer sociedade e, neste sentido, existem regras para a sua composição, mas não podem existir regras para sua eliminação.

Não obstante a atual Constituição Federal enuncie a liberdade sindical e a prioridade da negociação coletiva direta entre os trabalhadores e empregadores, por meio de seus sindicatos, a forte incidência de normas estatais impossibilita a regulamentação autônoma e a solução do conflito pelo Poder Judiciário ainda é o procedimento mais utilizado.

\footnotetext{
${ }^{80}$ RUPRECHT, Alfredo. op. cit., p. 189.

${ }^{81}$ SIQUEIRA NETO, José Francisco. Direito do trabalho \& democracia: apontamento e pareceres, cit., p. 127.
} 
Tudo isso é reflexo da influência direta do sistema fascista italiano, que trouxe as bases de nosso corporativismo sindical, que tinha como lógica a manutenção das relações coletivas atreladas ao Estado, que limitava a produção de normas resultantes da autonomia privada coletiva, com vistas a preservar os interesses da nação. Apesar das inconveniências do corporativismo sindical, não podemos deixar de destacar a importância provocada nas relações individuais de trabalho, ao proporcionar estrutura jurídica que sempre procurou proteger o insuficiente, especialmente num momento de grande desnível econômico.

Com toda mudança ocorrida no sistema de trabalho, torna-se desnecessária a intervenção repressora do Estado, que deverá, segundo Siqueira Neto ${ }^{82}$, apenas exercer seu papel de "organizador do sistema e fiador da liberdade sindical". E nesse sentido operaram-se inúmeras discussões no Fórum Nacional sobre Contrato Coletivo e Relações de Trabalho no Brasil, objetivando-se o desenvolvimento de um efetivo sistema participativo de relações de trabalho, com amplo estímulo ao sistema negocial de trabalho.

Os conflitos coletivos são basicamente resolvidos mediante autocomposição ou heterocomposição ${ }^{83}$. A autotutela (ou autodefesa) significa a defesa do direito pelo próprio titular e é considerada por alguns doutrinadores, como Otavio Bueno Magano $^{84}$ e Zamora y Castilho como forma de solução de conflitos. Alguns casos de autotutela são admitidos em direito e, no campo do Direito Coletivo do Trabalho, a greve e o lockout são algumas formas de sua manifestação. Entendemos que a autodefesa não deve ser considerada como um meio de solução, e sim como um método utilizado para exteriorização do conflito coletivo ${ }^{85}$. Não se trata, ainda, de uma espécie de autocomposição, pois deriva da imposição da vontade de uma única parte à outra por meio de uma manifestação de força.

\footnotetext{
${ }^{82}$ SIQUEIRA NETO, José Francisco. A modernidade necessária. In: FÓRUM NACIONAL SOBRE CONTRATO COLETIVO E RELAÇÕES DO TRABALHO NO BRASIL. Brasília: Ministério do Trabalho, 1994. p. 23.

${ }^{83}$ NASCIMENTO, Amauri Mascaro. Compêndio de direito sindical. 4. ed. São Paulo: LTr, 2006. p. 293.

${ }^{84}$ MAGANO, Octavio Bueno. op. cit., v. 3, p. 183. Para Magano, tutela seria a solução jurisdicional; autocomposição seria representada pela conciliação, pela mediação e pela arbitragem e a autodefesa seria a defesa direta de interesses pelo próprio titular.

${ }^{85}$ NASCIMENTO, Amauri Mascaro. Compêndio de direito sindical, cit., p. 294, ressalta que "a greve pode ser, para alguns, forma de solução de conflitos e para outros não, apenas meio de pressão que pode conduzir a uma forma de solução do conflito".
} 
A autocomposição corresponde à pacificação do litígio pela ação legítima das partes, que pode ser feita com a ajuda ou não de um terceiro ${ }^{86}$. A conciliação e a mediação são formas de autocomposição no direito coletivo de trabalho, sendo que a mediação, cujo tema será aprofundado no capítulo seguinte, conta com a presença de um terceiro que poderá produzir, entre outros efeitos, a aproximação das partes na realização de um acordo. Ela significa o meio mais natural de solução de conflitos, pois a busca do consenso é o primeiro passo utilizado antes de se partir para uma solução heterocompositiva.

A negociação coletiva de trabalho é um meio específico de solução de conflitos e representa uma das possibilidades de conciliação, vez que dela pode decorrer a realização do Acordo Coletivo.

A heterocomposição corresponde a outro meio de solução de conflitos, onde a solução é imposta por um terceiro alheio à vontade das partes, mediante um ato de autoridade e poder. A arbitragem e a tutela jurisdicional do Estado são espécies de heterocomposição, sendo que na primeira as partes elegem e outorgam poderes para um árbitro, que irá decidir o conflito impondo decisão com força vinculante. Ela é pouco utilizada no Brasil e será tratada com maiores detalhes no capítulo seguinte, no tópico relativo à comparação de tal meio com a mediação.

Já a via jurisdicional é bastante utilizada em nosso ordenamento toda vez que as partes não conseguem obter a celebração de acordos ou convenções coletivas de trabalho e o Poder normativo constitui o instrumento de que se vale o Estado para intervir nos conflitos coletivos.

No presente capítulo trataremos da conciliação, da negociação coletiva e da solução jurisdicional. A arbitragem será enfocada no capítulo seguinte, onde trataremos da mediação e especificaremos a distinção de tal instituto com as demais formas de composição.

Como já salientado no capítulo anterior, a análise sociológica dos conflitos e a crise existente em nosso Poder Judiciário, demonstram a necessidade de se buscar meios alternativos à solução dos conflitos de trabalho. Não queremos com isso dizer que o correto seria abandonar o modo de solução estatal. O ideal é que se estabeleça uma

\footnotetext{
${ }^{86}$ DINAMARCO, Cândido Rangel. Instituições de direito processual civil. São Paulo: Malheiros Ed., 2003. v, 1, p. 119, esclarece que " existe autocomposição quando os sujeitos envolvidos no conflito, ou um deles unilateralmente, encontra caminho apto à pacificação".
} 
política pública de incentivo à autocomposição, disseminando tal meio de solução de conflitos com o objetivo de atingir a pacificação contínua da sociedade, tanto pela via jurisdicional quanto pelos meios extrajudiciais.

Otávio Pinto e Silva, ao analisar a necessária revisão das formas de solução dos conflitos de trabalho, observa que o atual sistema jurídico não atende mais à crescente demanda de justiça, sendo imperiosa a busca de alternativas para alcançarmos um direito mais eficaz ${ }^{87}$, pois se o direito do trabalho contemporâneo, por meio de medidas de incremento da autonomia privada coletiva e da negociação coletiva, busca uma menor intervenção estatal na regulamentação das condições do trabalho, "é natural que as partes envolvidas nos conflitos procurem solucionar suas pendências por conta própria” ${ }^{\text {" }}$. E é nesse contexto que as formas de autocomposição dos conflitos coletivos de trabalho, notadamente a mediação, assumem especial relevância, como pretendemos demonstrar neste estudo.

\subsection{Acesso à Justiça: modernização do conceito}

A resolução dos conflitos encontra-se tratada também pelo direito processual $^{89}$, que, por imposição de sua própria técnica, sofre da natural propensão ao formalismo e ao isolamento. Os institutos próprios de jurisdição, ação, defesa e processo evidenciam um notável aprimoramento técnico e científico do direito processual, na medida em que afirma sua autonomia, mas muitas vezes percebe-se certa desvalorização do contexto político-social em que o direito processual se insere. Segundo Dinamarco ${ }^{90}$, o direito processual "não vai diretamente à realidade da vida e nem fala a linguagem do homem comum".

Por meio da atividade jurisdicional, o Estado busca atingir objetivos que se situam no campo jurídico (atuação da vontade do direito substancial), no campo social (pacificação com justiça; educação para os próprios direitos e respeito aos alheios) e no

\footnotetext{
${ }^{87}$ SILVA, Otávio Pinto e. Subordinação, autonomia e parassubordinação nas relações coletivas de trabalho. São Paulo: LTr, 2004. p. 177.

${ }^{88}$ Id. Ibid., p. 179.

${ }^{89}$ Conforme CINTRA, Antônio Carlos Araújo; DINAMARCO, Cândido Rangel; GRINOVER, Ada Pelegrini. op. cit., p. 40, "o direito processual corresponde ao complexo de normas que regem o método de trabalho para que o Estado desempenhe sua função jurisdicional".

${ }^{90}$ DINAMARCO, Cândido Rangel. A instrumentalidade do processo. 12. ed. São Paulo: Malheiros Ed., 2005. p. 11.
} 
político (afirmação do poder estatal; participação democrática). Dentro da concepção de que o processo deve estar voltado não apenas como instrumento técnico mas também de acordo com o contexto político-social da sociedade, a jurisdição expressa não apenas um poder do Estado, mas também uma função desenvolvida pelo Estado para a sociedade, que consiste na solução de litígios com vistas à paz social, e ainda um dever perante os cidadãos, que pode ser expressado através da garantia do direito de ação.

Assim, o sistema processual deve ser visto como instrumento que visa à consecução de determinados fins, que se identificam nos seguintes escopos: político, que consiste na estabilidade das instituições políticas e na participação dos cidadãos nas decisões de Estado por meio do processo social e jurídico; social, que se realiza por meio da paz social operada pela eliminação dos conflitos e pela educação para a defesa dos próprios direitos e respeito aos alheios; e jurídico, que reside na atuação da vontade do direito perante a lei.

Estudos atuais do direito processual analisam o sistema jurídico de acordo com os valores sociais e políticos da nação. Como observa Ovídio A. Baptista da Silva $^{91}$

\begin{abstract}
na medida em que as causas determinantes da crise do direito transcendem os domínios que lhe pertencem, para lançar raízes nas áreas mais profundas e vastas da ciência política, somos forçados a considerar, em nossas análises, estas dimensões históricas e sociológicas condicionantes de nossos problemas específicos; particularmente, cabe investigar as condições reais de nossa sociedade, inspiradas nos ideais democráticos, e o grau de compatibilidade entre os instrumentos utilizados pela jurisdição, de inspiração pré-capitalista, e as novas tendências de democracia social.
\end{abstract}

Observa-se, assim, que o Poder Judiciário, embora essencial para o desenvolvimento social, sofre diversas críticas relacionadas não somente à morosidade e formalidade de seus procedimentos como também ao distanciamento da realidade social. Se de um lado ele representa uma conquista histórica de garantia da imparcialidade e independência para o alcance da segurança jurídica, de outro lado ele não é suficiente para dar vazão ao volume e às peculiaridades de conflitos que afloram diariamente. O enfoque

\footnotetext{
${ }^{91}$ SILVA, Ovídio A. Baptista. Democracia moderna e processo civil. In: GRINOVER, Ada Pelegrini; DINAMARCO, Cândido Rangel; WATANABE, Kazuo (Coords.). Processo e participação. São Paulo: Ed. Revista dos Tribunais, 1988. p. 104.
} 
formalístico do direito, que o identifica como um "sistema de normas" produzidas pelo Estado, simplifica a realidade por negligenciar o contexto social.

O escopo social do processo é reafirmado com a propagação do uso de meios complementares de resolução dos conflitos, o que amplia, conseqüentemente, o conceito de eliminação do conflito para se atingir a pacificação das partes.

Com isso, a idéia de que o acesso aos órgãos judiciais constitua o único significado da acepção jurídica de acesso à justiça demonstra-se ultrapassada e equivocada, pois, atualmente, a preocupação fundamental é com a "justiça social", que visa à busca de procedimentos que sejam condizentes à proteção dos direitos e administração dos conflitos. Como ressaltada anteriormente, o fenômeno do acesso à Justiça deve ser compreendido como a possibilidade material de conviver em uma sociedade onde o Direito e a Justiça são realizados de forma concreta, seja por meio da atuação judiciária do Estado, através de seu poder soberano, seja por meio do estímulo ao uso das formas prévias e alternativas de resolução de conflitos. Necessário enfatizar que os valores centrais do processo judiciário tradicional devem ser mantidos e que o "acesso à justiça" deve englobar as duas formas de processo $^{92}$.

Segundo Mauro Cappelletti, "para assegurar o direito no ordenamento jurídico é necessário torná-lo efetivo" ${ }^{93}$. Ou seja, "em vez de uma concepção contextual do direito, unidimensional, que se limita à declaração de normas, afirma-se uma concepção tridimensional, em que: (i) uma primeira dimensão reflete o problema, necessidade ou exigência social que induz à criação de um instituto jurídico; (ii) a segunda dimensão reflete a resposta ou solução jurídica, por sinal uma resposta que, além das normas, inclui as instituições e processos destinados a tratar daquela necessidade, problema ou exigência social; (iii) enfim, uma terceira dimensão encara os resultados, ou o impacto, dessa resposta jurídica sobre a necessidade, problema ou exigência social." ${ }^{94}$ Assim, o enfoque tridimensional do direito exige, inicialmente, a consciência das necessidades, dos problemas e das expectativas sociais que o instituto jurídico visa abarcar.

No tocante ao acesso à justiça, Cappelletti indica três obstáculos que tornam, na realidade, a Justiça inacessível para grande parte da população. O primeiro

\footnotetext{
${ }^{92}$ CAPPELLETTI, Mauro; GARTH, Bryant. op. cit., p. 93.

${ }^{93}$ CAPPELLETTI, Mauro. Os métodos alternativos de solução de conflitos no quadro do movimento universal de acesso a justiça. Tradução do inglês por J. C. Barbosa Moreira. Revista de Processo, São Paulo, v. 19, n. 74, p. 82, abr./jun. 1994.

${ }^{94}$ Id. Ibid., nota 5.
} 
deles é o "obstáculo econômico", que impede que muitas pessoas, por motivo econômico, tenham pouco ou nenhum acesso à representação adequada. $\mathrm{O}$ "obstáculo organizacional" é o que se exterioriza diante da defesa dos interesses difusos. Nessa hipótese, “ou ninguém terá direito a corrigir a lesão a um interesse coletivo, ou o prêmio para qualquer indivíduo que buscar essa correção é pequeno demais para induzi-lo a tentar uma ação".95 $\mathrm{O}$ terceiro, chamado de "obstáculo processual", diz respeito à inadequação do processo contencioso tradicional, que, dentre as alternativas propostas por Cappelletti para sua superação, está a busca de métodos alternativos de solução de conflitos.

Para o citado autor, é muito importante que a atuação da justiça coexistencial, baseada em formas conciliatórias, caminhe ao lado da justiça contenciosa, onde a decisão jurisdicional se destina apenas a compor um conflito já existente. Ao contrário do que ocorre na justiça contenciosa, a justiça coexistencial procura resolver o conflito preservando a convivência pacífica das partes envolvidas e, conseqüentemente, a visão futura do relacionamento. ${ }^{96}$

Como salientado em algumas partes do presente estudo, o modelo tradicional de jurisdição carrega a característica da conflituosidade. É constante a busca da a solução do litígio na própria litigância, através da sentença e do sistema recursal, perpetuando-se o litígio. Kazuo Watanabe ${ }^{97}$ comenta que a própria cultura da sentença, arraigada entre os que lidam com o Direito e a própria comunidade, que se opõe à cultura da pacificação, é o grande obstáculo para a solução contenciosa dos conflitos de interesse. Ocorre que algumas questões, principalmente as decorrentes das relações continuadas, recomendam soluções dentro de um modelo consensual, independentemente da intervenção do Poder Judiciário. Necessário, assim, aperfeiçoar o modelo tradicional de aplicação da Justiça que funciona integrada ao Estado - monopólio jurisdicional - e ao

\footnotetext{
${ }^{95}$ CAPPELLETTI, Mauro; GARTH, Bryant. op. cit.

${ }^{96}$ CAPPELLETTI, Mauro. Problemas de reforma do processo civil nas sociedades contemporâneas. Revista de Processo, São Paulo, v. 17, n. 65, p. 127-143, jan./mar. 1992; ver também Ada ..... - “ a justiça tradicional se volta para o passado, enquanto a justiça informal se dirige ao futuro. A primeira julga e sentencia; a segunda compõe, concilia, previne situações de tensões e rupturas, exatamente onde a coexistência é um relevante elemento valorativo".

${ }^{97}$ WATANABE, Kazuo. Cultura da sentença e cultura da pacificação. In: TARSHELL, Flávio Luiz; MORAES, Maurício Zanoide de (Orgs.). Estudos em Homenagem à Professora Ada Pellegrini Grinover. São Paulo: Ed. DPJ, 2005. p. 685. Diz o autor: "Toda ênfase é dada à solução dos conflitos por meio de processo judicial, em que é proferida uma sentença, que constitui a solução imperativa dada pelo representante do Estado. O que se privilegia é a solução pelo critério do "certo ou errado", do "preto ou branco", sem qualquer espaço para a adequação da solução, pelo concurso da vontade das partes, à especificidade de cada caso".
} 
mesmo tempo assimilar o modelo consensual com suas novas técnicas de resolução de conflitos.

Deve-se ressaltar que o processo deve ser visto, preponderantemente, sob a ótica da participação dos conflitantes e não sob a ótica da eliminação dos conflitos, privilegiando-se, assim, o desenvolvimento de mecanismos voltados à realização do fim social do processo. O objetivo de amplo acesso a uma ordem jurídica justa deve, principalmente, levar em conta os destinatários, principalmente nos casos em que se visa à relação continuada dos envolvidos, onde a composição deve ser feita segundo critérios e valores importantes para as partes.

O processualista mexicano Zamorra Y Castilho esclarece que o processo judicial, ao tratar exclusivamente dos interesses juridicamente tutelados, exclui aspectos do conflito que são possivelmente tão importantes ou até mais relevantes do que aqueles juridicamente tutelados ${ }^{98}$. Como salienta José Francisco Siqueira Neto" "o interesse coletivo além de ser uma qualificação do interesse individual, é, concomitantemente, uma qualificação das relações humanas atingida pela interligação de aspirações e sentimentos, através da convivência e dos meios que determinam sua possibilidade”.

Nota-se que o estímulo à postura não-adversarial das partes envolvidas numa disputa possibilita o estreitamento de contatos e relações e colabora com a necessária maturação das alternativas para o conflito. Ou seja, a análise de todos os fatores que envolvem a relação estimula a atuação das partes como colaboradores na busca da resolução, fortalecendo, com isso, a relação social existente ${ }^{100}$.

Isso se torna particularmente relevante quando entre as partes objetivam relações duráveis, complexas e que merecem ser conservadas. E a verdadeira Justiça só é alcançada quando todas as questões que envolvem o relacionamento dos interessados são discutidas, maturadas e negociadas. A implementação de um "modelo mediacional" de

\footnotetext{
${ }^{98}$ ALCALÁ-ZAMORA Y CASTILLO, Niceto. Proceso, autocomposición y autodefensa: contribución al estudio de los fines del proceso. México: Ed. Universidad Autônoma Nacional do México, 1991. p. 238.

${ }^{99}$ SIQUEIRA NETO, José Francisco. Contrato coletivo de trabalho: perspectiva de rompimento com a legalidade repressiva, cit., p. 48.

${ }^{100}$ Interessante constatar a classificação feita por Morton Deustsch, na obra The Resolution of Conflit. Construtive and Destructive Processes, parcialmente traduzido na obra de Azevedo, André Gomma, Estudos em arbitragem, mediação e negociação, cit., onde se verifica a distinção dos processos de resolução dos conflitos em processos construtivos e destrutivos, salientando que nos processos construtivos as partes concluem a relação processual com o fortalecimento da relação social preexistente à disputa. Já nos processos destrutivos, tal relação social é enfraquecida ou rompida em razão da forma pela qual é conduzida, por carregar feição competitiva onde cada parte busca "vencer" a disputa, partindo, na maioria das vezes, da errônea percepção de que os interesses das partes não podem coexistir.
} 
resolução dos conflitos colabora com a conquista da pacificação social e da harmonia entre as pessoas. O presente estudo privilegia, assim, o desenvolvimento de mecanismos voltados à realização do escopo social do processo, empregando-se como meio de pacificação ao conflito tanto a solução jurisdicional, quanto a autocomposição alcançada com o auxílio de um terceiro. Manifesta, pois, a necessidade de adequação e capacitação dos operadores do sistema processual, para possibilitar a inserção dos novos modelos processuais.

A finalidade do Poder Judiciário é a pacificação social. E mais do que a pacificação, a principal função do processo é a atuação da ordem jurídica. E nesse aspecto torna-se importante a distinção entre a pacificação do conflito como eliminação da controvérsia posta em juízo, que corresponde ao conceito tradicional de pacificação como função do Poder Judiciário, e a pacificação das partes em conflito pela composição de seus reais interesses. Busca-se, além da pacificação jurídica, a pacificação social e, portanto, independentemente do processo e do procedimento desenvolvidos para a resolução dos conflitos no âmbito jurisdicional, também cabe ao Judiciário incentivar técnicas que mais aproximem o cidadão da verdadeira Justiça.

\subsection{A ONU e a Cultura da Paz}

A Cultura da Paz se insere no marco de respeito aos direitos humanos e possibilita uma visão diferente do conflito. Ela não é pautada na ausência de conflito; ao contrário, reconhece a existência deste e busca estimular a composição dos conflitos pelas próprias partes. A promoção e a manutenção da paz constituem os principais objetivos das Nações Unidas, tanto que, em 1997, a Assembléia Geral das Nações Unidas proclamou o Ano 2000 como o Ano Internacional da Cultura da Paz e o período de 2001 a 2010 como a "Década Internacional por uma Cultura de Paz e Não-violência", conferindo à UNESCO (Organização das Nações Unidas para a Educação, Ciência e a Cultura) a coordenação do movimento mundial de transição da cultura da guerra para uma cultura de solidariedade.

A Declaração e Programa de Ação sobre uma Cultura da Paz, aprovada pela Organização das Nações Unidas em 13 de setembro de 1999, por meio da Resolução no 53/243, reconhece que "a paz não é apenas a ausência de conflitos, mas que também requer um processo positivo, dinâmico e participativo em que se promova o 
diálogo e se solucionem os conflitos dentro de um espírito de entendimento e cooperação mútuos". Assim, a ONU reconhece que o conceito de paz não elimina a noção de conflito, indo ao encontro da teoria sociológica do conflito proposta por Dahrendorf, analisada no primeiro capítulo deste estudo.

A implantação e o desenvolvimento de sistemas alternativos de resolução de conflitos constitui um caminho necessário e importante para a possibilidade de soluções pacíficas e justas aos conflitos, sendo uma das recomendações das Nações Unidas. Observe-se que o artigo $1^{\circ}$, letra “d”, da Resolução n ${ }^{\circ} 53 / 243$ da ONU $^{101}$, estabelece o compromisso com a solução pacífica dos conflitos como sendo um dos valores em que se baseia uma Cultura de Paz e o Conselho Econômico e Social das Nações Unidas (ECOSOC), por meio da Resolução 1999/26, de 28 de julho de 1999, recomendou que os Estados considerem, no contexto de seus sistemas de Justiça, o desenvolvimento de procedimentos alternativos ao processo tradicional e a formulação de políticas de mediação e justiça restaurativa ${ }^{102}$.

Destaque-se, ainda, que na Resolução no 26 da ONU, de 28 de julho de 1999, o Conselho Econômico e Social das Nações Unidas recomenda que os Estados desenvolvam a promoção dos chamados ADRs - Alternative Dispute Resolution. Todas essas medidas visam um efetivo desenvolvimento de uma cultura favorável a sistemas alternativos de resolução de conflitos nas autoridades judiciais, sociais e outras responsáveis pelo cumprimento da lei e pelo atendimento e promoção dos direitos do cidadão.

Percebe-se, assim, que a administração de conflitos por meio de métodos alternativos de resolução de disputas é uma tendência universal, que deve ser vista não como substitutivo do direito fundamental de acesso à Justiça pública, mas como

\footnotetext{
${ }^{101}$ Resolução $\mathrm{n}^{\text {o }} 53 / 242$, art. $1^{\circ}$ "Una cultura de paz es un conjunto de valores, actitudes, tradiciones, comportamientos y estilos de vida basados en: a)......... d) El compromiso con el arreglo pacífico de los conflictos

${ }^{102}$ Justiça Restaurativa é um processo colaborativo que envolve as partes afetadas por um crime, que visa determinar qual a melhor forma de reparar o dano causado pela transgressão. Sua essência é a resolução de problemas de forma colaborativa e as práticas restaurativas proporcionam, àqueles que foram prejudicados por um incidente, a oportunidade de reunião para expressar seus sentimentos, descrever como foram afetados e desenvolver um plano para reparar os danos ou evitar que aconteça de novo. O engajamento cooperativo é seu elemento essencial da justiça restaurativa; procura-se restaurar sentimentos e relacionamentos positivos levando em consideração as necessidades emocionais e sociais daqueles afetados por um crime. $\mathrm{O}$ sistema de justiça restaurativa tem como objetivo não apenas reduzir a criminalidade, mas também o impacto dos crimes sobre os cidadãos. A capacidade da justiça restaurativa de preencher essas necessidades emocionais e de relacionamento é o ponto-chave para a obtenção e manutenção de uma sociedade civil saudável.
} 
mecanismo complementar capaz de ajudar e estimular a produção de espaços em que a gestão de interesses antagônicos se faça com base numa cultura de pacificação e respeito ao direito.

Necessário que, além do desenvolvimento de estruturas que possibilitem a atuação de mecanismos extrajudiciais e judiciais voltados à pacificação, que os operadores do direito tenham consciência do novo papel que devem desenvolver na sociedade. Com base em tal consciência foi lançado o "Movimento Nacional de Modernização do Poder Judiciário", através de uma parceria entre o Poder Judiciário, Ministério Público e Advocacia, com vistas a uma reforma institucional, e não meramente política, do Poder Judiciário brasileiro, passando, necessariamente, pela modernização intelectual dos juízes. O referido movimento, além de apresentar propostas para ampliação do acesso à Justiça, tem demonstrado a preocupação dos operadores do direito com os mecanismos extraprocessuais ${ }^{103}$.

\subsection{Negociação coletiva}

A negociação coletiva é o procedimento utilizado para chegar à produção de uma norma jurídica (acordo ou convenção coletiva de trabalho) que ponha fim ao conflito e satisfaça a pretensão das partes. Ela representa todo o processo de discussão que envolve, de um lado, os interesses dos empregadores (por meio de um ou mais sindicatos econômicos) e, de outro lado, os trabalhadores (através de um ou mais sindicatos profissionais).

Representa, assim, um instrumento de atividade autônoma de produção de norma jurídica relativa às relações de trabalho, que, em razão de sua função normativa, passa a ser, em conjunto com a lei, uma importante fonte do Direito do Trabalho.

O direito do trabalho contemporâneo tem na autonomia privada coletiva uma de suas mais notáveis fontes de criação de normas jurídicas, e a negociação coletiva

\footnotetext{
${ }^{103}$ GAJARDONI, Fernando da Fonseca. Técnicas de aceleração do processo. São Paulo: Lemos \& Cruz, 2003. p. 80. O Projeto Movimento pela Conciliação, lançado pelo Conselho Nacional de Justiça, que visa a realização de acordos tanto em demandas já levadas à Justiça, quanto em conflitos ainda não jurisdicionalizados, é fruto de tal mentalidade. Ressalte-se, no entanto, que a iniciativa difere da proposta da mediação, vez que a "conciliação" e não propriamente "reconstrução do conflito" é o carro chefe de tal movimento. Maiores detalhes sobre o Projeto poderão ser obtidos em: CONSELHO NACIONAL DE JUSTIÇA. Movimento pela conciliação. Projeto Conciliar. Disponível em: $<$ http://www.conciliar.cnj.gov.br/cms/verTexto.asp?pagina=projeto $>$.
} 
destina-se à celebração do instrumento normativo que irá regular os contratos de trabalho de todos os empregadores e trabalhadores submetidos aos limites da representação das partes. Assim, a negociação coletiva encontra seu fundamento na autonomia privada coletiva, que é o poder de auto-regulamentação dos próprios interesses das partes e representa o poder que os grupos profissionais possuem de elaborar normas e vincular-se às fontes do direito. E nesse sentido Enoque Ribeiro dos Santos ${ }^{104}$ esclarece que a análise da autonomia coletiva envolve a concepção de que o direito não emerge apenas do Estado, admitindo-se a existência de outras produções normativas, "quer na esfera supra-estatal (organizações internacionais, como a OIT), quer na esfera infra-estatal (grupos associativos, corpos intermediários, organizações comunitárias e movimentos sociais), dentre os quais se situam as organizações de trabalhadores e de empregadores".

Amauri Mascaro Nascimento ${ }^{105}$ afirma que a negociação coletiva está na base da formação do direito do trabalho como uma das suas fontes de produção e carrega a característica do plurinormativismo do direito. Para o referido autor, negociação coletiva representa uma forma de desenvolvimento de poder normativo dos grupos sociais segundo uma concepção pluralista, que não reduz a formação do direito positivo à elaboração do Estado, e destina-se à formação consensual de normas e condições de trabalho que serão aplicadas a um grupo de trabalhadores e empregadores.

No campo do Direito Coletivo do Trabalho, a negociação coletiva entre os protagonistas sociais envolvidos é o caminho mais adequado e eficiente para a solução dos conflitos do trabalho, por ser uma forma direta, flexível, espontânea e rápida de levar o conflito a uma solução definitiva em clima de entendimento e de cooperação entre as partes. De acordo com João de Lima Teixeira Filho ${ }^{106}$, ela configura-se como um processo democrático de autocomposição de interesses pelos próprios atores sociais, com o objetivo de fixar condições de trabalho a uma determinada coletividade de empregados (determinada empresa ou de toda uma categoria econômica) e regular as relações entre as entidades estipulantes. O referido "processo democrático" significa que o Direito do Trabalho passou a conceder às partes, desde que representadas por seus órgãos de classe, a possibilidade de buscar o entendimento na satisfação de seus interesses, abrindo-se, assim,

\footnotetext{
${ }^{104}$ SANTOS, Enoque Ribeiro dos. Direitos humanos na negociação coletiva: teoria e prática jurisprudencial. São Paulo: LTr, 2004. p. 73.

${ }^{105}$ NASCIMENTO, Amauri Mascaro. Iniciação do direito do trabalho. 6. ed. São Paulo: LTr, 1980 e Compêndio de direito sindical, cit., p. 305.

${ }^{106}$ TEIXEIRA FILHO, João de Lima; SÜSSEKIND, Arnaldo; MARANHÃO, Délio; VIANNA, Segadas. Instituições de direito do trabalho. São Paulo: LTr, 2000. v. 2, p. 1164.
} 
a realização de um processo de integração de vontade e de interesses sem a necessidade da participação do Judiciário.

Magano e Mallet ${ }^{107}$ entendem que negociação coletiva é o processo destinado à superação do conflito coletivo e nela devem necessariamente participar os sindicatos dos trabalhadores e dos empregadores (Constituição, art. $8^{\circ}, \mathrm{VI}$ ), excetuando-se as negociações voltadas à celebração de acordo coletivo, que, por definição, dispensa a participação do sindicato patronal.

Percebe-se, pois, que o termo negociação coletiva tem vários significados, estreitamente relacionados entre si. Num sentido primário, representa o método ou procedimento da negociação, ou seja: designa uma série de atividades de comunicação, pressão e persuasão desenvolvidas por determinados sujeitos, com o objetivo de regulação de certas relações sociais. Em uma segunda acepção, a negociação coletiva refere-se ao conjunto de convenções ou acordos coletivos de trabalho alcançados em um determinado âmbito e, por fim, pode se referir às regras ou pautas preestabelecidas por lei ou pelas próprias partes negociadoras para a determinação dos sujeitos, do objeto, do procedimento e da estrutura da negociação coletiva.

Siqueira Neto ${ }^{108}$ substitui a terminologia "negociação coletiva" por "contratação coletiva" e a justificativa reside na visão de que todo procedimento visa chegar a um contrato.Para o autor, contratação coletiva de trabalho é o conjunto de procedimentos necessários para a efetivação dos ajustes. Representa o conjunto de medidas de apoio para a realização da contratação dos acordos ${ }^{109}$.

Denota-se, portanto, que a negociação coletiva é o caminho por onde as partes interessadas, devidamente representadas, percorrem para chegar a um ajuste final. Os instrumentos jurídicos que emanam do processo de negociação coletiva no Brasil são a convenção, o acordo coletivo e, mais recentemente, o contrato coletivo ${ }^{110}$.

\footnotetext{
${ }^{107}$ MAGANO, Octavio Bueno; MALLET, Estêvão. O direito do trabalho na Constituição. Rio de Janeiro: Forense, 1993. p. 294.

${ }^{108}$ SIQUEIRA NETO, José Francisco. Contrato coletivo de trabalho: perspectiva de rompimento com a legalidade repressiva, cit., p. 16.

${ }^{109}$ Id. Ibid., p. 101. Segundo o autor, "contratação coletiva é o conjunto de princípios e fundamentos que determinam as regras de conduta antes, durante e depois das conversações entre as partes. Contratação coletiva significa a apreensão desses códigos de procedimentos que possibilitem tornar público como e quando se iniciam as tentativas, de que forma, quais seus limites, como e de que forma se encerram os entendimentos, bem como eventuais conflitos de interesses aflorados durante o processo."

${ }^{110}$ SILVA, Otávio Pinto e. A contratação coletiva como fonte de direito do trabalho, cit., p. 41.
} 
A convenção coletiva encontra-se definida no artigo 611 da $\operatorname{CLT}^{111} \mathrm{e}$ apresenta os seguintes aspectos: 1. somente os sindicatos estão legitimados para negociar, sendo que as federações e confederações poderão fazê-lo apenas de forma subsidiária, nos casos de categorias inorganizadas em sindicatos em determinada base territorial; 2 . quanto aos efeitos normativos, é aplicável de maneira geral para todos os membros das categorias econômicas e profissionais representadas pelos respectivos sindicatos convenentes.

O acordo coletivo é mais restrito, pois é estipulado no âmbito de empresa e vem regulado pelo parágrafo $1^{\circ}$ do artigo 611 da CLT $^{112}$. A diferença entre os dois instrumentos reside, basicamente, no âmbito de aplicação: as convenções coletivas aplicam-se a toda categoria e os acordos aplicam-se apenas aos trabalhadores das empresas acordantes $^{113}$.

No que se refere ao contrato coletivo de trabalho, inexiste uma definição legal ao instituto, vez que as referências existentes nas Leis 8.542/92 (política salarial) e 8.630/93 (regime de trabalho nos portos) apenas referem-se ao contrato coletivo como um terceiro tipo de convênio que pode ser obtido por meio da negociação coletiva, sendo que em nenhum momento apresentam qualquer definição.

Siqueira Neto ${ }^{114}$ procura demonstrar que a Constituição de 1988 abriu a possibilidade da celebração de convênios mais amplos que as convenções coletivas (convênios intercategoriais ou gerais). Tal convênio pode ser tido como contrato coletivo de trabalho que, segundo o autor, seria "o negócio jurídico de caráter normativo através do qual sindicatos ou outros sujeitos devidamente legitimados, regulamentam, criam e estipulam condições de trabalho". Assim, o Contrato Coletivo de Trabalho representa um importante instrumento que regula não apenas a negociação coletiva, mas também outros aspectos das relações trabalhistas. O mesmo autor ${ }^{115}$ esclarece que as propostas apresentadas no Fórum Nacional do Trabalho apontam as seguintes concepções em relação

\footnotetext{
${ }^{111}$ Artigo 611 da CLT define convenção coletiva como o "acordo de caráter normativo, pelo qual dois ou mais sindicatos representativos de categorias econômicas e profissionais estipulam condições de trabalho aplicáveis, no âmbito das respectivas representações, às relações individuais de trabalho".

${ }^{112}$ Artigo 611, parágrafo $1^{\circ}$ da CLT: "é facultado aos sindicatos representativos das categorias profissionais celebrar acordos coletivos com uma ou mais empresas da correspondente categoria economica, que estipulem condições de trabalho, aplicáveis no âmbito da empresa ou das empresas acordantes às respectivas relações de trabalho”.

${ }^{113}$ Ressalte-se que o artigo $7^{\circ}$, XXVI, da Constituição Federal inclui no rol dos direitos dos trabalhadores " $o$ reconhecimento das convenções e acordos coletivos de trabalho".

${ }^{114}$ SIQUEIRA NETO, José Francisco. Contrato coletivo de trabalho: perspectiva de rompimento com a legalidade repressiva, cit., p. 131-132.

${ }^{115}$ SIQUEIRA NETO, José Francisco. A modernidade necessária, cit., p. 14-15.
} 
ao Contrato Coletivo de Trabalho: 1. trata-se de um instrumento de abrangência nacional por categorias ou intercategorias, que regula aspectos gerais das relações de trabalho; 2 . o contrato coletivo representa uma regulamentação de caráter nacional destinada a determinar os procedimentos de negociação (estrutura, vigências dos instrumentos normativos, por exemplo); 3. o contrato coletivo incentiva e sustenta a própria negociação coletiva.

Como procedimento, a negociação coletiva é mais simplificada e mais rápida do que a lei e possui maiores possibilidades de precisar as peculiaridades de cada setor econômico e profissional, ou cada empresa para a qual é instituída. Por ser mais específica para segmentos menores, ela permite a auto-regulação de detalhes que a lei, norma de ordem geral, para toda a sociedade, não pode nem deve reger ${ }^{116}$.

A negociação coletiva deve propiciar a dinâmica necessária para que o direito do trabalho se torne o instrumento capaz de atender as necessidades surgidas no mundo do trabalho, garantindo-se a participação efetiva do trabalhador nas decisões que produzirão diretamente efeitos na sua vida e indiretamente atingindo toda uma comunidade. Tal participação direta pressupõe a livre manifestação de vontades e a consciência política adquirida pelo próprio exercício da democracia, que leva à compreensão do respeito mútuo e da reciprocidade de interesses.

Assim, como ressalta Maria Cristina Haddad de Sá ${ }^{117}$, a importância da negociação coletiva pode ser vista sob os seguintes aspectos: 1. como papel de autogestão de interesses (busca de solução por meio da negociação); 2. possibilidade de alcançar a celeridade do resultado; 3. consciência e preparo para o exercício da democracia pelos próprios interessados; 4. constatação de desenvolvimento político, profissional e cultural, necessários para obtenção de êxito nos procedimentos negociais coletivos; 5 . convivência pacífica entre grupos de interesses conflitantes dentro da relação de trabalho.

O primeiro passo para o incremento da negociação coletiva é criar condições para que ela seja realizada num ambiente neutro, propício a discussões, debates e exposições de pontos de vista sem o receio de qualquer interferência do Estado. Segundo

\footnotetext{
${ }^{116}$ Segundo Amauri Mascaro Nascimento - Compêndio de direito sindical, cit., p. 308 - "A legislação é genérica, aplicável, de modo geral, a todos os membros da sociedade que se enquadram na sua tipicidade. A convenção é limitada a determinado espaço geográfico, a base territorial do sindicato, e a um número restrito de pessoas, as representadas por ele. A lei é geral; a convenção é específica”.

${ }^{117}$ SÁ, Maria Cristina Haddad de. Negociação coletiva de trabalho no Brasil. São Paulo: LTr, 2002. p. 62.
} 
Hugo Gueiros Bernardes ${ }^{118}$, a norma convencional é de elaboração rápida e de revisão sistemática e serve sempre para solucionar os conflitos habituais do trabalho, podendo abranger tanto o genérico, em sentido mais favorável para o trabalhador, como o específico. Não obstante, como já discorremos anteriormente, o sistema intervencionista brasileiro (lei e poder normativo) impede a vazão das insatisfações sociais.

Assim, a prática da negociação coletiva no Brasil exige a criação de estímulos para negociar e desestímulos para o uso desnecessário dos Tribunais do Trabalho e uma definição de regras para resolver os conflitos coletivos por meio da mediação e arbitragem.

\subsubsection{Princípios}

Como já ressaltado, a negociação coletiva, além de meio de produção de normas de trabalho, é um mecanismo de solução de conflitos coletivos, incentivado e reconhecido pelo ordenamento jurídico. Por constituir um procedimento convencionado pelas partes, alguns princípios são intrínsecos a tal atividade e acabam possibilitando e favorecendo o êxito das negociações. Os princípios a seguir destacados representam a base para a realização prática dos procedimentos capazes de levar a um bom resultado o esforço negocial das partes.

Hugo Gueiros Bernardes ${ }^{119}$ elabora uma teoria dos princípios da negociação coletiva, classificando-os em quatro grupos: 1)princípios relativos à boa-fé ou lealdade; 2) princípios referentes ao procedimento; 3) princípios relativos ao direito de greve; 4) princípios concernentes à responsabilidade das partes.

O princípio da boa-fé é um princípio geral do Direito, baseado na confiança recíproca, que implica na clareza e lealdade dos propósitos revelados pelas partes. Representa o dever ético de agir com honestidade e fidelidade. Como expressão da autonomia coletiva, a negociação coletiva possui uma relevante função social, e por tal motivo o princípio da boa fé revela ainda mais a sua importância, já que deve presidir toda e qualquer forma de negociação. Por ser um princípio geral do direito contratual, encontra-

\footnotetext{
${ }^{118}$ BERNARDES, Hugo Gueiros. O desenvolvimento da negociação coletiva no Brasil. LTr: revista legislação do trabalho. São Paulo, v. 54, n. 12, p. 1445, dez. 1990.

${ }^{119}$ Id. Princípios da negociação coletiva. In: TEIXEIRA FILHO, J. L. (Coord.). Relações coletivas de trabalho: estudos em homenagem ao Ministro Arnaldo Süssekind. São Paulo: LTr, 1989. p.357-369.
} 
se justificado na negociação coletiva, sendo que sua inobservância pode prejudicar o sucesso da negociação.

Como ressalta João de Lima Teixeira Filho ${ }^{120}$, o princípio da boa fé deve estar presente tanto na fase de discussão sobre o acordo, por meio da concentração de esforços para chegar ao êxito da negociação, como após o entendimento, tanto no que se refere à redação das condições pactuadas quanto na fase da execução.

Hugo Gueiros Bernandes ${ }^{121}$ acrescenta que referido princípio tem vários desdobramentos, que poderiam ser assim elencados:

1) o dever formal de negociar: as partes obrigam-se a examinar as propostas e a formular contrapropostas, de maneira que sejam explicitados os motivos de eventual rejeição de uma cláusula ou proposta ${ }^{122}$;

2) as partes precisam pôr-se de acordo antecipadamente sobre a finalidade e o alcance da negociação: devem estipular os interesses recíprocos envolvidos na negociação, de caráter econômico ou profissional, que possibilitem normas e condições de trabalho para melhoria das condições de vida e de trabalho dos empregados e para incremento da produtividade no trabalho e da harmonia nas relações laborais;

3) princípio do conglobamento: representa uma garantia da unidade da negociação, para que os mesmos argumentos não possam ser repetidos e para que as partes jamais possam perder de vista o conjunto da negociação. É uma técnica que não permite a invocação de prejuízo como objeção a uma cláusula, sem a demonstração de que o alegado prejuízo também é resultado da negociação globalmente considerada em seu resultado final, proposto ou aceito. O objetivo é que as partes desenvolvam uma garantia de unidade de negociação, sem o desvio do conjunto das discussões nem a repetição de argumentos.

Assim, o compromisso de negociar com boa-fé impõe às partes a estipulação prévia quanto à finalidade da negociação, a análise das propostas, a motivação de eventual recusa e a apresentação de contrapropostas. Além disso, considerando a dinâmica do processo negocial, as partes obrigam-se a realizar constantes reuniões, sem determinação de prazo para a conclusão, devendo sempre ser observada a técnica do

\footnotetext{
${ }^{120}$ TEIXEIRA FILHO, João de Lima; SÜSSEKIND, Arnaldo; MARANHÃO, Délio; VIANNA, Segadas. op. cit., p. 1166.

${ }^{121}$ BERNARDES, Hugo Gueiros. Princípios da negociação coletiva, cit., p. 357-370.

${ }^{122}$ Otávio Pinto e Silva, (A contratação coletiva como fonte de direito do trabalho, cit., p. 105, insere nesse dever formal de negociar noções como obrigatoriedade de reuniões periódicas, prazo mínimo de duração das negociações e de cada discussão, fundamentação de cada proposta e contraproposta etc.
} 
conglobamento, que determina que a negociação deve ser realizada com respeito ao exame conjunto da pauta e ao conjunto das discussões.

No grupo de princípios relativos ao procedimento da negociação, Hugo Gueiros Bernardes ${ }^{123}$ reconhece a necessidade de fixação de regras mínimas de conduta, como: a) dever de paz, no sentido de abstenção do uso de medidas de força (greve, por exemplo) durante um determinado período; b) antecedência em relação à data-base, como meio de evitar convocações inesperadas, ao fim do prazo; c) exaustão da pauta, onde as partes são obrigadas a examinar e responder a cada item ou cláusula; d) credenciamento dos representantes das partes na negociação, para evitar perda de tempo em debates com pessoas não-autorizadas; e) garantia formal de cumprimento de todos os compromissos assumidos; f) dever de influência, por meio do qual as partes se comprometem a influir sobre os seus representados para garantir a efetividade do que for ajustado; g) dever de adequação, onde as partes se comprometem a proceder com racionalidade, amoldando suas pretensões e respostas à realidade econômica; h) dever de informação, significa que as partes devem prestar, reciprocamente, as informações necessárias para justificar suas propostas e respostas $^{124}$.

Os princípios relativos ao direito de greve foram enumerados por Hugo Gueiros Bernardes ${ }^{125}$ da seguinte maneira: a) indispensabilidade da conciliação prévia; b) proporcionalidade, concebida como uma noção que envolve o uso do recurso de forma proporcional aos seus fins; c) greve como medida extrema, a ser utilizada como último recurso e apenas após tentativa de conciliação, mediação ou arbitragem; d) ter efeito suspensivo sobre a execução dos contratos de trabalho, com a não-obrigatoriedade de pagamento de salários durante o período de paralisação; e) dever de salvaguarda, onde as partes devem prescrever regras de condenação dos abusos e de prevenção dos prejuízos ao interesse público; f) limitação das greves de solidariedade, que devem ser apenas simbólicas; g) limitação do objeto dos piquetes, que devem persuadir os trabalhadores quanto à greve e seus motivos pela divulgação pacífica das informações, sendo vedadas as ações intimidatórias ou agressivas.

\footnotetext{
${ }^{123}$ BERNARDES, Hugo Gueiros. Princípios da negociação coletiva, cit., p. 359-363.

${ }^{124}$ Segundo Amauri Mascaro Nascimento (Compêndio de direito sindical. São Paulo: LTr, 2005. p. 340), o dever de informação destina-se a fornecer ao sindicato os dados disponíveis, pelo empregador, úteis ou necessários para a avaliação das pretensões. Ele não é bem recebido pelo empregador e a concorrência e a confidencialidade de alguns dados que envolvam interesses de clientes são alguns dos motivos que levam a empresa a limitar a transparência de seus dados.

${ }^{125}$ BERNARDES, Hugo Gueiros. Princípios da negociação coletiva, cit., p. 363-369.
} 
Já com relação ao princípio da responsabilidade das partes, o mesmo autor $^{126}$ afirma a necessidade de especificação geral do dever das partes de zelar pelo respeito aos princípios e normas da negociação e a fixação de responsabilidade patrimonial das entidades de trabalhadores e empregadores, por meio de sanções (multas ou pagamento dos salários do período da paralisação, para o empregador, e multa ou proibição temporária do exercício da greve, para os trabalhadores).

O princípio da compulsoriedade negocial significa que as partes integrantes no processo de negociação coletiva não podem se negar a negociar. Segundo Enoque Ribeiro dos $\operatorname{Santos}^{127}$, esse princípio suscita que as partes são levadas a exaurir o processo negocial. A obrigatoriedade da tentativa prévia de solução do conflito coletivo por meio de negociação coletiva faz com que a solução do litígio seja primeiramente tentada pela via autocompositiva.

O princípio do contraditório é, para José Augusto Rodrigues Pinto ${ }^{128}$, o ponto de partida necessário, pois o diálogo tem que discorrer da contradição de pretensões que se procura harmonizar. Assim, é necessário que as partes tenham pretensões contraditórias que motivem a discussão, vez que tais pretensões são o próprio objeto da negociação.

Outro princípio importante é o da cooperação, que pressupõe a vontade de colaboração entre as partes envolvidas, sem o que a negociação restaria prejudicada.

O princípio da paz social consiste na suspensão temporária da hostilidade implicitamente assumida pelas partes no momento em que concluem o instrumento normativo que pauta os interesses pactuados na negociação coletiva ${ }^{129}$. Representa um esforço de compreensão e de respeito mútuo entre as partes, apesar das diversidades e da contraposição de interesses, vez que o objetivo mediato da negociação é a própria relação de trabalho que deve ser preservada.

\footnotetext{
${ }^{126}$ BERNARDES, Hugo Gueiros. Princípios da negociação coletiva, cit., p. 363-369.

${ }^{127}$ SANTOS, Enoque Ribeiro dos. op. cit., p. 110.

${ }^{128}$ PINTO, José Augusto Rodrigues. Direito sindical e coletivo do trabalho. São Paulo: LTr, 1998. p. 172.

${ }^{129}$ Segundo João de Lima Teixeira Filho, Instituições de direito do trabalho, cit., p. 1167, a obrigação de manter a paz persiste enquanto vigente o instrumento normativo.
} 


\subsubsection{Normas e Procedimentos}

Como expressão do princípio da autonomia privada coletiva ${ }^{130}$ dos particulares e da liberdade sindical, a negociação coletiva ganha especial importância a partir da Constituição Federal de 1988, especialmente nos artigos $7^{\circ}$, $8^{\circ}$ e 114, que introduziu vários aspectos da democracia sindical e valorizou a negociação coletiva. Não obstante, permaneceram ranços corporativistas que atravancam o pleno desenvolvimento da negociação coletiva, quais sejam: poder normativo, unicidade sindical, contribuição sindical compulsória e o regime de categorias.

A livre negociação, hoje em dia, se pauta pela Constituição e pela CLT. Os dois institutos contribuem pouco para estimular e disciplinar o processo. A Constituição, apesar de submeter (artigo $7^{\circ}$ ) inúmeras matérias à negociação, em seu artigo 114 permite que as partes se recusem a negociar. E a CLT, na parte que trata das convenções coletivas de trabalho, dedica-se apenas ao resultado da negociação e não à organização do processo. O art. 616 da CLT dispõe que os sindicatos e as empresas, quando provocados, não podem se recusar à negociação coletiva.

Como se pode observar, a Constituição Federal reconhece (artigo $7^{\circ}$, inciso XXVI) os resultados da negociação coletiva (convenções e acordos coletivos de trabalho) e o art. $7^{\circ}$, incisos XIII e XIV, a institucionaliza como forma de regulamentação das condições de trabalho, assegurando a participação obrigatória dos sindicatos para sua realização (art. $8^{\circ}$, inciso VI). Mais adiante, o artigo 114 , parágrafos $1^{\circ}$ e $2^{\circ}$, coloca a negociação coletiva como o primeiro percurso a ser trilhado pelos entes coletivos para tentativa de composição quanto aos interesses contrapostos, seguida da arbitragem (facultativa) e do ajuizamento de dissídio coletivo de trabalho (atualmente sujeito a “comum acordo" dos interessados, pela Emenda 45/2004).

As Convenções 154 e 98 da OIT, ratificadas pelo Brasil, também versam sobre negociação coletiva e objetivam estimular tal prática em todo o mundo e, especialmente, entre os países subscritores. A Convenção 154 da OIT, ratificada em 29/09/1994 (Decreto 1256/94), define a negociação coletiva como um procedimento

\footnotetext{
${ }^{130}$ A autonomia privada coletiva implica a possibilidade de criação de normas próprias (possibilidade dos atos dos particulares se tornarem jurídicos) não-identificadas com as da ordem estatal. Para Magano, a autonomia deve ser também concebida como sub-produto da concepção pluralista da sociedade, fundada na observação de que nesta não existe apenas um, mas vários centros geradores de normas jurídicas. (MAGANO, Octavio Bueno. op. cit., v. 3, p. 14).
} 
destinado à elaboração de contratos coletivos de trabalho, tendo por finalidade fixar as condições de trabalho e emprego e regular as relações entre empregadores e trabalhadores ou entre as suas organizações representativas ${ }^{131}$.

A Convenção 98, relativa à aplicação dos Princípios do Direito de Organização e de Negociação Coletiva, foi ratificada em 29/06/1953 (Decreto $\mathrm{n}^{\circ}$ 33.196/53) e dispõe sobre medidas para incentivar a fixação das normas e condições de trabalho através de contratos coletivos. Em seu artigo $4^{\circ}$ está previsto o seguinte:

Medidas apropriadas às condições nacionais serão tomadas, se necessário, para estimular e promover o pleno desenvolvimento e utilização de mecanismos de negociação voluntária entre empregadores ou organizações de empregadores e organizações de trabalhadores, com o objetivo de regular, mediante acordos coletivos, termos e condições de emprego $^{132}$.

A Recomendação 91 da OIT, propõe normas procedimentais a respeito da negociação coletiva, assim como sua eficácia, aplicabilidade, efeitos e princípios que regem sua interpretação e a Recomendação 163 trata especificamente do método de aplicação da negociação coletiva e dos meios de sua promoção.

Uma das condições indispensáveis para a validade da negociação coletiva é o direito e a possibilidade de os trabalhadores se agruparem livremente por meio de organizações, associando-se livremente. Nesse sentido, o artigo $8^{\circ}$ da Constituição dispõe expressamente que a associação profissional ou sindical é livre e seus incisos III e VI estipulam, respectivamente, que "ao sindicato cabe a defesa dos direitos e interesses coletivos ou individuais da categoria, inclusive em questões judiciais ou administrativas” $e$ "é obrigatória a participação dos sindicatos nas negociações coletivas de trabalho". Cabe lembrar que o modelo de organização sindical é o legalista, com o princípio da unicidade sindical e os enquadramentos categoriais definidos por lei.

\footnotetext{
${ }^{131}$ ORGANIZAÇÃO INTERNACIONAL DO TRABALHO - OIT. Negociações coletivas, cit., p. 136. O artigo $2^{\circ}$ apresenta a definição da seguinte forma:

"Art. $2^{\circ}$. Para os efeitos desta Convenção, o termo 'negociação coletiva' compreende todas as negociações que se realizam entre um empregador, um grupo de empregadores ou uma ou mais organizações de empregadores, de um lado, e uma ou mais organizações de trabalhadores, de outro, para:

a) definir condições de trabalho e termos de emprego; e/ou

b) regular as relações entre empregadores e trabalhadores; e/ou

c) regular as relações entre empregadores ou suas organizações e uma organização de trabalhadores ou organizações de trabalhadores."

${ }^{132}$ ORGANIZAÇÃO INTERNACIONAL DO TRABALHO - OIT. Negociações coletivas, cit., p. 120.
} 
A negociação coletiva inicia-se pela convocação por parte dos sindicatos (dos empregados e dos empregadores, de suas respectivas categorias profissional ou econômica), a fim de participarem das Assembléias Gerais com o intuito de se formular uma pauta de reivindicações, avançando-se para discussão e deliberação sobre a conveniência da celebração de acordo ou convenção coletiva de trabalho. Importante esclarecer que somente na ausência de sindicato em determinado município é que sua respectiva federação assumirá o seu papel ou, na ausência desta, a confederação da categoria exercerá tal representatividade ${ }^{133}$.

O Ministério do Trabalho é um dos órgãos estatais institucionalmente incumbido de buscar o acordo entre as partes em uma mesa de negociação ${ }^{134}$. Ressalte-se, no entanto, que o referido órgão não é dotado das mínimas condições para que se chegue ao desenvolvimento do processo de negociação. O que se observa é que as partes envolvidas não são satisfatoriamente esclarecidas sobre as condições que permeiam a negociação. Assim, o Ministério do Trabalho não tem apresentado as condições necessárias para propor as bases para uma boa negociação, fazendo com que seja mais uma ficção científica do que um instituto realmente existente na prática.

Dependendo do resultado das negociações, decorrerá a autocomposição do conflito e, conseqüentemente, a realização de um convênio coletivo de trabalho, entendendo-se como tal a expressão genérica que compreende o acordo coletivo, a convenção coletiva e o contrato coletivo de trabalho, ou a heterocomposição, que ocorre quando a solução do conflito é determinada por terceiros (jurisdição e arbitragem).

Inegável a importância da negociação no contexto da resolução dos conflitos, especialmente nos conflitos coletivos de trabalho. Não obstante, em nossos cursos jurídicos não observamos a existência de estudos sistemáticos de suas técnicas e

\footnotetext{
${ }^{133}$ Art. 611, par. 20, da CLT: “As Federações e, na falta destas, as confederações representativas de categorias econômicas ou profissionais poderão celebrar convenções coletivas de trabalho para reger as relações das categorias a elas vinculadas, inorganizadas em Sindicatos, no âmbito de suas representações".

${ }^{134}$ Alguns Estados e Municípios possuem Sistemas de Negociação Permanente voltados à aplicação de metodologia participativa de tratamento de conflitos e de encaminhamento de assuntos pertinentes às relações funcionais e de trabalho dos servidores públicos. Em São Paulo, no ano de 2002, foi criado o convênio Sistema de Negociação Permanente (SINP) entre a Prefeitura e representantes sindicais do funcionalismo municipal. O Governo do Estado da Bahia constituiu o Sistema Estadual de Negociação Permanete - SENP, que possui os mesmos objetivos que os descritos acima. E, em relação aos funcionários públicos federais, o Projeto de Lei 966/2007 pretende criar o SINP - Sistema de Negociação Permanente e estabelecer como instâncias deliberativas as Mesas de Negociação Permanente, a fim de garantir a negociação entre administração e servidor, com a conseqüiente obrigatoriedade da aplicação do resultado negociado.
} 
princípios. A seguir, procuraremos apresentar, sem a intenção de esgotar a matéria a respeito, alguns aspectos importantes a serem observados em qualquer tipo de conflito em que se pretenda sua resolução pacífica.

\subsubsection{Técnicas de negociação}

O estudo da negociação como um processo (um conjunto de atos ordenados lógica e cronologicamente para a composição de uma controvérsia) tornou-se objeto de estudos acadêmicos apenas na segunda metade do século XX. Segundo André Gomma de Azevedo ${ }^{135}$, o marco inicial foi a obra do Professor da Universidade de Harvard, Howard Raiffa intitulada "The Art and Science of Negotiation", onde foram introduzidos conceitos de estatística, economia e psicologia na análise desse processo de resolução de conflitos de interesses. Nesse campo, foi particularmente relevante a aplicação da teoria dos jogos ao processo de tomada de decisão.

A partir do crescente interesse sobre a negociação, a Faculdade de Direito da Universidade de Harvard organizou o núcleo de pesquisas sobre a negociação, ganhando forma seu estudo como método e como procedimento estruturado em fases e voltado ao alcance de soluções de ganhos mútuos ${ }^{136}$. Nesse período podem ser distinguidas duas grandes correntes: Negociação distributiva ou posicional e Negociação Integrativa.

As diferenças de uma e de outra forma de negociar afetam toda a estrutura do jogo "negociação". Passaremos, assim, a examinar essas técnicas de negociação, sendo que o uso de cada uma delas dependerá de cada caso concreto e também do comportamento que a outra parte vier a adotar no processo de negociação.

\footnotetext{
${ }^{135}$ AZEVEDO, André Gomma de. O processo de negociação: uma breve apresentação de inovações epistemológicas em meios autocompositivos. Revista dos Juizados Especiais, Brasília, v. 5, n. 11, p. 13-24, jul./dez. 2001.

${ }^{136}$ URY, William; PATTON, Bruce. Como chegar ao sim: negociação de acordos sem concessões. Tradução Vera Ribeiro \& Ana Luiza Borges. 2. ed. Rio de Janeiro: Imago Ed., 1994. p. 15-17.
} 


\subsubsection{Negociação distributiva ou posicional}

$\mathrm{Na}$ negociação distributiva as partes têm interesses opostos em relação ao objeto em discussão e cada uma busca maximizar o seu ganho na negociação, o que necessariamente leva à minimização do ganho da outra parte. Nesse tipo de negociação cada parte apega-se à sua posição, cedendo o mínimo possível e sempre com o objetivo de que o acordo permaneça o mais próximo possível da posição que defende; a percepção dos envolvidos é de que só conseguirão um bom acordo se este refletir a posição defendida pela parte, contrária à posição do lado adversário.

Representa um jogo não cooperativo e de soma-zero, uma vez que o que um ganha, o outro perde. Não há cooperação das partes exatamente por considerarem que qualquer colaboração implicará a vitória do adversário e pelo mesmo motivo cada parte tenderá a não ceder informações à outra. As negociações posicionais são muito desgastantes para um relacionamento e, normalmente, as partes que adotam esse tipo de negociação não têm em mente relações continuadas.

Nesse tipo de negociação, as partes não permitem a introdução de elementos extrínsecos à negociação, por se prenderem às suas posições iniciais. Segundo Raiffa $^{137}$, a negociação distributiva, em relação ao contexto em que se desenvolve, encontra-se relacionada às seguintes hipóteses: 1. cada membro da barganha é monolítico: não deve convencer eventuais representados de que eles devem ratificar o acordo; 2. as partes estão interessadas apenas no jogo da barganha; 3. as partes não estão preocupadas com relação continuada, nem com problemas ou favores precedentes.

Tal modelo de negociação não é suficiente para possibilitar a ampla satisfação das partes envolvidas, já que não corresponde ao atendimento dos interesses em jogo. A única preocupação do negociador é obter a melhor vantagem possível, sendo que o apego às posições iniciais e a postura de obtenção do maior ganho possível normalmente inviabiliza a negociação.

\footnotetext{
${ }^{137}$ RAIFFA, H.; RICHARDSON, J.; METCALFE, D. Negotiation análisis: the sciense and art of collaborative decisión making. Cambridge: Harvard University Press, 2002. p. 109.
} 


\subsubsection{Negociação integrativa}

$\mathrm{Na}$ negociação integrativa existem diversos pontos distintos sobre os quais versam os debates. Ela ocorre nos casos em que se discute mais de uma questão e mais de um objetivo a se atingir, permitindo a consideração de todos esses diversos elementos para se obter soluções mais satisfatórias para as partes.

As partes não são necessariamente oponentes e a afirmativa de que quanto mais uma receber, menos a outra obterá da negociação não é mais absolutamente verdadeira.

Também chamada como negociação colaborativa ou negociação cooperativa, os enfoques desse tipo de negociação consolidaram-se com os trabalhos da equipe de pesquisadores do Projeto de Negociação da Universidade de Harvard, sendo que com a publicação do livro Getting to Yes (Como Chegar ao Sim), de Roger Fisher e William Ury, em 1981, introduziu-se o conceito de negociação baseada em princípios, como contraposição à negociação baseada na barganha por posições ${ }^{138}$.

Segundo estes autores, qualquer método de negociação pode ser julgado por três critérios: 1) deve produzir um acordo sensato ${ }^{139}$; 2) deve ser eficiente; 3) deve aprimorar, ou, pelo menos, não prejudicar o relacionamento entre as partes. E sob esses aspectos a negociação baseada em princípios resulta num melhor desempenho.

A negociação baseada em interesses representa um jogo cooperativo, onde o objetivo é alcançar os interesses mútuos dos negociadores, e de soma não-zero, onde ambas as partes encontram uma situação capaz de atender as suas necessidades, sendo possível trazer elementos exteriores ao objeto da negociação. Ainda, as partes encaram a negociação como uma oportunidade na qual podem encontrar o ponto ótimo de cooperação, não obstante cada parte tenha seus interesses e aspirações. Há, assim, uma mudança de enfoque: o problema é comum e as partes podem tentar resolvê-lo de forma

\footnotetext{
${ }^{138}$ URY, William; PATTON, Bruce. op. cit., p. 16, segundo o autor "o método da negociação baseada em princípios, desenvolvido no Projeto de Negociação de Harvard, consiste em decidir questões a partir de seus méritos, e não através de um processo de regateio centrado no que cada lado se diz disposto a fazer e a não fazer. Ele sugere que você procure benefícios mútuos sempre que possível e que, quando seus interesses entrarem em conflito, você insista em que o resultado se baseie em padrões justos, independentes da vontade de qualquer dos lados. O método da negociação baseada em princípios é rigoroso quanto aos méritos e brando com as pessoas".

${ }^{139}$ Id. Ibid., p. 101. Para os autores, um acordo sensato deve: 1)atender aos interesses legítimos de cada uma das partes na medida do possível; 2) resolver imparcialmente os interesses conflitantes; 3) ser duradouro e levar em conta os interesses da comunidade.
} 
mutuamente satisfatórias. Para tanto, é necessário negociar sobre os reais interesses em jogo, e não somente sobre as posições.

\subsubsection{Diferenças entre interesses e posições. Procedimento na negociação baseada em interesses}

O problema básico de uma negociação não reside nas posições conflitantes, mas sim no conflito entre as necessidades, desejos, interesses e temores de cada parte, em relação ao contexto da negociação. Os interesses ${ }^{140}$ são identificados como as reais motivações das partes. São eles que motivam as pessoas. Os interesses são aquilo que fez com que as partes decidissem de determinada forma, enquanto a posição é algo já decidido $^{141}$. Diferentemente das posições, que se apresentam de forma explícita e concreta durante as negociações, os interesses geralmente se manifestam em forma não-expressa, e, por vezes, incoerentes. A negociação deve atender aos interesses subjacentes, não às posições declaradas, que muitas vezes não refletem o real interesse objetivado ${ }^{142}$. Por tal motivo, para que uma negociação obtenha êxito, é necessário desenvolver instrumentos que permitam identificar os interesses de cada uma das partes.

Segundo Ury, Fisher e Patton a conciliação dos interesses funciona pelos seguintes motivos: 1) para cada interesse, geralmente existem diversas posições possíveis e capazes de satisfazê-lo; 2) quando se examinam realmente os interesses motivacionais por trás das posições opostas, freqüentemente se descobre uma posição alternativa que atende não apenas aos interesses de uma das partes como também da outra.

Por trás das posições opostas há interesses comuns e compatíveis, assim como interesses conflitantes. Em muitas negociações um exame criterioso dos interesses

\footnotetext{
${ }^{140}$ FREITAS JÚNIOR, Antonio Rodrigues. op. cit., p. 238, esclarece que "em todo o conflito está presente, em alguma medida, a contrariedade entre as posições de dois ou mais sujeitos. Por posições entendam-se os objetivos explícitos que cada sujeito persegue em sua relação com os demais. Por trás das posições assumidas pelas partes, com maior, menor ou nenhum grau de consciência, os sujeitos são portadores de necessidades, desejos e de valores (materiais ou imateriais). A esses a literatura de ADRs, por influência da chamada Escola de Harvard, passou a designar interesses".

${ }^{141}$ URY, William; PATTON, Bruce. op. cit., p. 58-59.

${ }^{142}$ FREITAS JÚNIOR, Antonio Rodrigues. op. cit. Nas palavras do autor, "as relações em que se verifica a ocorrência de conflito tendem a fixar os sujeitos nas respectivas posições, mediante um processo recíproco e retroalimentador de 1. incompreensões (sejam decorrentes de diferentes percepções sobre a natureza dos interesses a elas subjacentes, sejam ocasionadas por distúrbios comunicativos que, com freqüência, se não forem provocados pelo conflito são por esse exacerbados); 2. exasperações emocionais e 3. colisão nos vetores comportamentais".
} 
subjacentes revela a existência de um número muito maior de interesses comuns ou compatíveis do que de interesses opostos. Os referidos autores apresentam algumas "regras" para identificar os interesses, que podem ser assim resumidas ${ }^{143}: 1$. perguntar "por quê": a técnica básica consiste em colocar-se no lugar do outro; 2. pergunte " por que não": pensar na escolha do outro e indagar por que não tomou outra decisão; 3. aperceber-se de que cada lado tem interesses múltiplos; 4. procurar identificar os interesses fundamentais que motivam as pessoas: os interesses mais poderosos são as necessidades humanas básicas; 5 . fazer uma lista discriminando os interesses de cada lado.

Outras regras básicas, além da concentração nos interesses, precisam ser observadas numa negociação cooperativa: 1. separar as pessoas dos problemas; 2. criar uma variedade de opções antes de decidir o que fazer; 3. utilizar critérios e padrões objetivos para o resultado; 4. ter uma alternativa ao acordo ${ }^{144}$.

O primeiro ponto, separar as pessoas dos problemas, significa que todos os envolvidos numa negociação precisam ser respeitados. Fundamental que o “problema das pessoas" seja tratado antes e separadamente do problema substantivo. É importante levar em conta que as partes diferem nas suas percepções, atuam afetados por emoções e apresentam dificuldades de comunicação. E nessa perspectiva é que a compreensão dos elementos subjetivos dos processos de negociação ganha importância ${ }^{145}$.

O acordo é um ato de vontade das partes, que só o celebram se isto lhes parecer conveniente e vantajoso. Por tal motivo é necessário considerar o outro como parte integrante da negociação. É preciso saber ouvir e identificar os reais interesses para construir uma solução conjunta, e uma estratégia bastante eficaz para a percepção do outro, e a identificação de seus interesses é o exercício de se colocar no lugar do outro ${ }^{146}$.

\footnotetext{
${ }^{143}$ URY, William; PATTON, Bruce. op. cit., p. 62, et seq.

${ }^{144}$ Id. Ibid.

${ }^{145}$ Ib. Ibid., p. 40, et seq. Segundo os autores, “compreender o pensamento da outra parte não é meramente uma atividade útil ajudá-lo a solucionar o problema. O pensamento do outro lado é o problema. Quer você esteja fechando um negócio ou resolvendo uma disputa, as diferenças são definidas pela diferença entre o seu pensamento e o dele. (...) o conflito não está na realidade objetiva, e sim na mente das pessoas. (...) Por mais útil que seja buscar a realidade objetiva, é a realidade tal como cada lado a vê que, em última instância, constitui o problema de uma negociação e abre caminho para uma solução".

${ }^{146}$ URY, William; PATTON, Bruce. op. cit., p. 41, et seq, os autores afirmam que "uma das formas de lidar com percepções diferentes consiste em explicitá-las e discuti-las com o outro lado. (...) "a capacidade de ver a situação tal como o outro lado o vê, por mais difícil que seja, é uma das mais importantes habilidades que um negociador pode possuir. Não basta saber se eles vêem as coisas de maneira diferente. Se você quiser influenciá-los, precisará também compreender empaticamente o poder do ponto de vista deles e sentir a força emociona com que acreditam nele."
} 
O segundo aspecto, necessidade de identificar opções ou alternativas criativas, permite a reflexão dos interesses de todas as partes envolvidas. As partes são estimuladas a expor todas as ações que poderiam resultar na composição do litígio, e é a partir desse momento que a utilização de critérios e padrões objetivos deve ser considerada para a avaliação dos possíveis acordos. Importante observar que a concepção de acordo justo não corresponde ao que cada parte considera como tal segundo seus padrões subjetivos, mas sim que as decisões são tomadas segundo critérios objetivos aceitos pelas partes.

Necessário identificar, finalmente, qual a melhor alternativa que a parte teria caso não consiga obter um acordo consensual. Com isso, a negociação será desenvolvida de forma equilibrada e consciente, por possibilitar que as partes avaliem a melhor estratégia a ser adotada, caso não seja possível a realização de um acordo dentro de bases razoáveis.

\subsection{Solução Jurisdicional. Poder normativo}

É inegável que a negociação coletiva desempenha papel importante na solução dos conflitos coletivos de trabalho. No insucesso da negociação coletiva, as partes podem recorrer ao Judiciário ${ }^{147}$ e obter uma solução jurisdicional. Como vimos anteriormente, dissídio coletivo é o processo judicial destinado à solução dos conflitos coletivos pela via jurisdicional. Sentença Normativa é a decisão dos referidos Dissídios, que possui natureza formal de sentença judicial e conteúdo normativo próprio de normas jurídicas.

O artigo 114, § 2. ${ }^{\circ}$, da Constituição Federal, com a redação que lhe foi dada pela EC n. 45/2004, estabelece o seguinte: "recusando-se qualquer das partes à negociação coletiva ou à arbitragem, é facultado às mesmas, de comum acordo, ajuizar dissídio coletivo de natureza econômica, podendo a Justiça do Trabalho decidir o conflito, respeitadas as condições mínimas legais de proteção ao trabalho, bem como as convencionadas anteriormente". Tal previsão remete ao fortalecimento da negociação coletiva e à diminuição do ajuizamento de dissídios coletivos, além de criar um pressuposto de procedibilidade do ajuizamento do dissídio coletivo que antes não existia.

\footnotetext{
${ }^{147}$ Art. $5^{\circ}, \mathrm{XXXV}$, e art. 114, par. $2^{\circ}$, ambos da Constituição Federal.
} 
Assim, a intenção do legislador, no tocante à necessidade do mútuo consentimento para a instalação do dissídio coletivo de natureza econômica, foi acabar com o costume das partes em se mostrarem pouco dispostas à negociação coletiva, que muitas vezes preferem acomodar-se no paternalismo estatal, destituindo-se da missão precípua de pacificar o conflito pela via conciliatória.

Se restar caracterizada como abusiva ou injurídica eventual recusa de consentimento para o ajuizamento conjunto do dissídio coletivo de natureza econômica, a parte prejudicada deverá, de imediato, ajuizar o dissídio coletivo e nele requerer, de forma incidental, o suprimento judicial da recusa da categoria econômica ou profissional contraposta, possibilitando-se, dessa maneira, a regular tramitação do dissídio coletivo de natureza econômica. Dessa maneira, a decisão incidental dessa circunstância produzirá os efeitos da declaração recusada, restando atendida a condição de procedibilidade exigida pelo parágrafo segundo do artigo 114 da Constituição Federal.

Instaurada a instância do dissídio coletivo, o Poder Judiciário tem a prerrogativa de fixar as condições laborativas, exercendo seu poder normativo. Referido poder sofre inúmeras críticas, o que nos leva a pensar na necessidade do desenvolvimento de formas alternativas de solução de conflitos coletivos de trabalho. A primeira delas diz respeito ao fato de que o exercício do poder normativo não é típica atuação jurisdicional, por não aplicar o direito ao caso concreto. Na verdade configura-se como atividade normativa exercida pelo Poder Judiciário, na medida em que cria norma abstrata e geral no âmbito de sua decisão. Com isso, a função dos juízes é desvirtuada, rompendo-se o equilíbrio dos poderes num Estado de Direito, pois os tribunais não atuariam dentro do mandato da lei, que dá competência de função jurisdicional e não função legislativa. Segundo Romita ${ }^{148}$, o artigo $1^{\circ}$ da Constituição Federal reafirma que o Brasil é uma

\footnotetext{
${ }^{148}$ ROMITA, Arion Sayão. O poder normativo da Justiça do Trabalho: a necessária reforma. Disponível em: <www.planalto.gov.br/ccivil_03/revista/Rev_22/artigos/art_arion.htm>. Acesso em: 3 jan. 2008. Acesso em: 3 janeiro de 2008. Para o autor, o poder normativo não encontra justificativa alguma no Estado democrático de direito e a necessária reforma do Poder Judiciário, no que diz respeito à Justiça do Trabalho, deveria, em conseqüência, abolir mencionado poder. A consagração do Poder Normativo pela Constituição Federal gera quatro antinomias:

" 1 a - entre o art. $1^{o}$, parágrafo único, e o art. $114, \S 2^{o}$ : se o povo exerce poder por intermédio de seus representantes eleitos, o poder normativo, exercido pelos juízes, não poderia ser acolhido pela Constituição, pois juízes não são representantes do povo;

$2^{a}$ - entre o art. $5^{o}$, inciso $L V$, que reconhece o princípio do contraditório sem qualquer exceção, e o art. 114, $\S 2^{\circ}$ : no exercício do poder normativo, a Justiça do Trabalho não é obrigada a observar o referido princípio, pois exerce jurisdição de eqüidade, dispensando a manifestação de contrariedade por parte da categoria econômica suscitada no dissídio coletivo;

$3^{a}$ - entre o art. 93, inciso IX e o art. 114, $\S 2^{o}$ : como decisão judicial, a sentença normativa não pode deixar de ser fundamentada, sob pena de nulidade; entretanto, o poder normativo se exerce como meio de
} 
democracia representativa e que a edição de normas compete exclusivamente aos representantes eleitos. Os juízes não são representantes do povo, tampouco são eleitos. Portanto, a edição de normas por juízes padece, no mínimo, do vício da ilegitimidade por parte daqueles que exercem este poder, posto que ele tenha assento constitucional, à luz do art. $114, \S 2 .^{\circ}$, da Constituição Federal.

Além das críticas baseadas no fato de que o surgimento do poder normativo deu-se durante a vigência do regime político chamado "Estado Novo", moldado em estilo corporativista, influenciado e originário da Carta del Lavoro de Mussolini, e, portanto, carregaria o fardo fascista em sua essência, há outras baseadas nos seguintes aspectos: na forma binária de adjudicação judicial; na lentidão do pronunciamento jurisdicional, que afeta a agilidade e rapidez das soluções (fundamentais nesse tipo de conflito); na falta de conhecimento dos magistrados para analisar casos complexos de organização do trabalho e suas conseqüências, combinado com o primado da uniformização de jurisprudência; no desprestígio da justiça pelo descumprimento de suas sentenças pelas partes ou pelo próprio Estado; na possibilidade de criar uma dependência psicológica nos trabalhadores e no fato de que estimularia a conflitividade das relações capital/trabalho ${ }^{149}$.

Segundo Brito Filho ${ }^{150}$, a competência normativa da Justiça do Trabalho sempre funcionou como apoio para as entidades sindicais incompetentes, que não conseguem sozinhas alcançar os objetivos de sua categoria, constituindo, junto com a unicidade sindical e com a contribuição sindical compulsória, "o tripé que caracteriza nosso sistema corporativista de organização sindical, totalmente falido, não só por ser autoritário, mas, principalmente, por ser rígido, que não permite o avanço das relações trabalhistas" ${ }^{\prime 151}$.

solução de controvérsia coletiva, mediante edição de normas (poder legislativo delegado), tarefa que dispensa fundamentação;

$4^{\mathrm{a}}$ - entre o art. $9^{\circ}$ e o art. $114, \S 2^{\circ}$ : enquanto o primeiro dispositivo assegura o exercício do direito de greve pelos trabalhadores, o outro o inviabiliza, pois o poder normativo é utilizado para julgar a greve, inibindo o entendimento direto entre os interlocutores sociais".

${ }^{149}$ RAMOS FILHO, Wilson. op. cit., p. 220.

${ }^{150}$ BRITO FILHO, José Cláudio Monteiro de. Mediação e arbitragem como meios de solução de conflitos coletivos de trabalho: atuação do Ministério Publico do Trabalho. LTr: revista legislação do trabalho, São Paulo, v. 62, n. 3, p. 347, mar. 1998.

${ }^{151}$ Também nesse sentido, SIQUEIRA NETO, José Francisco. Contrato coletivo de trabalho: perspectiva de rompimento com a legalidade repressiva, cit., p. 24, que ressalta que "o funcionamento global dos sindicatos tem sido caracterizado pela artificialidade representada por organizações oficiais sustentadas pela contribuição sindical e, literalmente, socorridas nas negociações salariais pelo Poder Normativo da Justiça do Trabalho, que tem exercido a essência do poder moderador, garantindo aos sindicatos desmobilizados aquilo que normalmente não conseguiria e evitando os 'abusos' dos mobilizados e mais representativos através da garantia da aplicação da lei". 
Assim, o poder normativo é incompatível com o instituto da negociação coletiva e com o reconhecimento pela Constituição do direito de greve e, enquanto não fizermos o uso de outros mecanismos para a solução dos conflitos, mediação, por exemplo, não mudaremos nosso momento histórico nem contribuiremos para o efetivo papel do Direito do Trabalho, que é o de conciliar os interesses do capital e do trabalho, cuja vinculação é perene.

\subsection{Conciliação na Justiça do Trabalho: Judiciária e Administrativa. Comissões de Conciliação Prévia}

Como forma institucionalizada de solução dos conflitos, a conciliação sempre esteve presente nos conflitos trabalhistas. Como exemplo, o Decreto que regulamentou a criação dos sindicatos e cooperativas (Decreto $\mathrm{n}^{\circ} 1.637$, de 5 de janeiro de 1907) já estimulava o "espírito de harmonia em patrões e empregados" e valorizava a organização pelos sindicatos dos conselhos permanentes de conciliação e arbitragem como forma de dirimir as controvérsias existentes.

Mais adiante, o Decreto $\mathrm{n}^{\mathrm{o}} 19.770$, de 19 de março de $1931^{152}$, regulamentou que os sindicatos deteriam o poder de negociação de acordos e convenções de interesse coletivo, podendo pleitear a proteção de direitos ao Ministério do Trabalho, sendo que em seu artigo $6^{\circ}$ constava expressamente o dever de colaboração dos sindicatos na aplicação das normas relativas à solução dos conflitos trabalhistas, por meio da instituição dos conselhos mistos e permanentes de conciliação e julgamento. E nesse contexto o Decreto $\mathrm{n}^{\mathrm{o}}$ 21.396, de 12 de maio de $1932^{153}$, instituiu as chamadas Comissões Mistas de Conciliação, compostas por representantes de empregados e empregadores, sob presidência de pessoa nomeada pelo Ministério do Trabalho, Indústria e Comércio e escolhida preferencialmente entre membros da $\mathrm{OAB}$, magistrados ou funcionários públicos, cuja competência limitava-se à tentativa de conciliação dos dissídios coletivos e à promoção da instauração de juízo arbitral, em caso de tentativa frustrada de composição.

\footnotetext{
${ }^{152}$ Art. 10 do Decreto 19.770/31: “Art. 10. Além do que dispõe o art. $7^{\circ}$, é facultado aos syndicatos de patrões, de empregados e de operarios celebrar, entre si, accordos e convenções para defesa e garantia de interesses reciprocos, devendo ser taes accordos e convenções, antes de sua execução, .ratificados pelo Ministerio do Trabalho, Industria e Commercio".

${ }^{153}$ Decreto $\mathrm{n}^{\mathrm{o}} 21.396$, de 12 de maio de 1932: arts. $2^{\mathrm{o}}, 13,14$ e 15.
} 
No mesmo ano foram instituídas as Juntas de Conciliação e Julgamento $^{154}$, destinadas à solução dos litígios individuais de trabalho, que, diferentemente das Comissões Mistas de Conciliação, que não poderiam exercer qualquer poder decisório (o poder decisório era privativo do Ministério do Trabalho), julgavam os conflitos no caso da impossibilidade de um acordo. Tal julgamento era feito numa única instância, com a possibilidade de a parte solicitar a avocação do processo pelo Ministério do Trabalho, no caso de comprovação de parcialidade dos julgadores ou violação expressa ao direito ${ }^{155}$.

Os artigos 21 e 22 de referido Decreto estimulavam a conciliação dos conflitos trabalhistas e, diante da ausência de conciliação, os órgãos competentes (Juntas de Conciliação e Julgamento, nos dissídios individuais e Ministério do Trabalho, nos coletivos), realizavam julgamento passível de execução junto ao Poder Judiciário.

A Constituição de $1946^{156}$ tornou a Justiça do Trabalho órgão de natureza jurisdicional com competência para a conciliação e julgamento dos conflitos resultantes das relações de trabalho, e as Juntas de Conciliação e Julgamento foram mantidas como órgãos do poder judiciário trabalhista. Tal situação perdurou com as Constituições Federais posteriores, sendo que a Emenda Constitucional no 24, de 1999, extinguiu a representação paritária e, conseqüentemente, as Juntas de Conciliação e Julgamento, que passaram a ser denominadas Varas do Trabalho. Tal alteração não modificou a inspiração conciliatória do instituto, notadamente no que se refere à exigência do esgotamento dos meios de composição para a propositura do dissídio coletivo.

O instituto da conciliação também é recomendado pela Organização Internacional do Trabalho, por meio da Convenção 154, de 1981, da Recomendação 92, da 1952 e da Convenção 98, de 1949. A conciliação corresponde a uma fase na busca de composição dos conflitos e pode estar presente em qualquer das formas de composição. No

\footnotetext{
${ }^{154}$ Decreto n n $^{\text {22.132, de }} 25$ de novembro de 1932, Art. 21. "Si o acôrdo ou a decisão passada em julgado nâo fôr cumprido, o funcionario incumbido de receber a queixa, a requerimento do interessado, extrairá cópia autentica do termo da respectiva audiencia, que valerá como titulo de, divida líquida e certa para a execução judicial. Art. 22. Afóra o cumprimento do acôrdo ou decisão, fica o infrator, ainda, sujeito á multa de $200 \$$ a 2:000\$000, aplicavel segundo os motivos alegados como determinantes da recusa, e pela maioria dos membros da Junta".

${ }^{155}$ Decreto $\mathrm{n}^{\circ}$ 22.132, de 25 de novembro de 1932: art. 18: Art. 18. As Juntas constituirão instancia unica para os julgamentos que proferirem, os quais só poderão ser discutidos nos embargos á sua execução; art. 29: Art. 29. É facultado ao ministro do Trabalho, Indústria e Comércio avocar qualquer processo em que haja decisão proferida, há menos de 6 mêses, pelas Juntas de Conciliação e Julgamento e na fórmula indicada no presente decreto, a requerimento da parte e provando esta ter havido flagrante parcialidade dos julgadores ou violação expressa de direito.

${ }^{156}$ Art. 123, Constituição Federal de 1946.
} 
direito coletivo de trabalho apresenta-se mediante a negociação coletiva, pelo acordo e convenção coletiva, e nesse sentido seria uma etapa da negociação coletiva. A conciliação administrativa, ocorrida perante as mesas redondas da DRT, é considerada por alguns como conciliação extrajudicial e por outros autores ${ }^{157}$ como mediação. A diferença entre os dois institutos será exposta no capítulo seguinte. No dissídio coletivo sempre haverá a possibilidade da composição; nesse caso, o acordo deverá ser homologado nos exatos termos estabelecidos pelas partes ${ }^{158}$.

O termo conciliação também é empregado na fase extra-processual, que antecede a propositura de uma ação trabalhista. São as chamadas Comissões de Conciliação Prévia, instituídas pela Lei 9958/2000, que inseriu os artigos 625-A a 625-H na CLT. Cuida-se de organismos ou instituições de conciliação extrajudicial, originados em acordo ou convenção coletiva, instituídos no âmbito de sindicatos ou de empresas, compostos paritariamente por membros indicados pelo empregador e eleitos pelos empregados no âmbito da empresa, grupo de empresas ou sindicatos, cujo objetivo é tentar conciliar os conflitos individuais de trabalho. As referidas comissões não possuem qualquer relação com o Mistério do Trabalho e Emprego, nem com a Justiça do Trabalho e não possuem poderes para julgar qualquer demanda.

Enquanto as negociações coletivas dizem respeito à solução dos conflitos coletivos de trabalho como prática anterior à interposição do dissídio coletivo, as Comissões de Conciliação Prévia visam à prévia solução judicial dos conflitos individuais do trabalho. Não obstante, é facultado às empresas e aos sindicatos a instituição das Comissões de Conciliação Prévia e, uma vez instituídas, torna obrigatória a tentativa de acordo perante tais órgãos. Importante observar que muitas delas não são bons exemplos em matéria de facilitação de entendimento pacífico e extrajudiciário de conflitos e já foram alvos de interferência do Ministério Público do Trabalho ${ }^{159}$; muitas vezes o mecanismo é

\footnotetext{
${ }^{157}$ NASCIMENTO, Amauri Mascaro. Compêndio de direito sindical, cit., p. 299. Para o autor "a conciliação é uma forma consensual de solução dos conflitos trabalhistas, e, nesse, ponto, é um modo de autocomposição. Mas não é mediação. É utilizada para a composição dos conflitos individuais. Nos conflitos coletivos desenvolve-se um procedimento de negociação entre as partes".

${ }^{158}$ RUSSOMANO, Mozart Victor. Comentários à Consolidação das Leis do Trabalho. 16. ed. Rio de Janeiro: Forense, 1994. v. 2, p. 942-943. Para o autor "a Justiça do Trabalho deve, apenas, homologar, ou não, o acordo nos autos da ação de dissídio coletivo, sem modificá-lo. A conciliação tem, juridicamente, a forma geométrica de um tabuleiro de xadrez: se modificarmos uma de suas linhas, todo o resto ficará prejudicado. Alterar uma cláusula é ferir a autonomia da vontade das partes, pois não se pode saber se, modificada essa cláusula, as demais condições do acordo seriam aceitas".

${ }^{159}$ Vide ação movida pelo Ministério Publico do Trabalho de São Paulo movida em face do SIMPI (autos $n^{\circ}$ 03046200302402000), cujo acórdão proferido pelo TRT/2 ${ }^{a}$ Região encontra-se anexado com o presente trabalho.
} 
utilizado ardilosamente como meio de quitação de verbas irrenunciáveis e como órgão homologatório de verbas rescisórias ${ }^{160}$.

Ocorre que muitas delas atendem à prévia finalidade conciliatória, a exigência de tentativa prévia de acordo perante tais comissões coloca-se como condição da ação trabalhista, já que, inobservado esse requisito, faltaria interesse de agir ${ }^{161}$. A questão é bastante polêmica e comungamos do mesmo entendimento de algumas Turmas do Tribunal Superior do Trabalho no sentido de que a Lei 9958/2000 não é inconstitucional e o procedimento instituído pelo art. 625-D da CLT representa condição da ação para o ajuizamento da reclamação trabalhista, além de incentivo à forma conciliatória de resolução de conflitos.

\footnotetext{
${ }^{160}$ FAVA, Marcos Neves. Comissões de conciliação prévia e crime de frustração de direito trabalhista. Disponível em: <http://www.trt02.gov.br/geral/tribunal2/Legis/CLT/Doutrina>. Acesso em: 10 jan. 2007.

${ }^{161}$ CARRION, Valentin. Comentários à CLT. 26. ed. São Paulo: Saraiva, 2001. fls. 459. Também nesse sentido, Narciso Figueiroa Júnior: não há inconstitucionalidade, pois o que a Constituição garante é o direito de demandar, sendo o direito de ação condicionado ao preenchimento de certos requisitos que podem ser estabelecidos em lei infraconstitucional (FIGUEIROA JUNIOR, Narciso. As recentes alterações na legislação trabalhista: leis ns. 9.957 e 9.958 de 12 de janeiro de 2000. LTr: revista legislação do trabalho, São Paulo, v. 64, n. 2, p. 197, fev. 2000) E Maurício Rands acentua: não se trata de exclusão de lesão de direito da apreciação do judiciário. A lei apenas acrescentou mais uma exigência para que surja o interesse de agir configurador da condição da ação a que se refere o inciso VI do art. 267 do CPC (RANDS, Mauricio. As comissões de conciliação previa. LTr: revista legislação do trabalho. São Paulo, v. 64, n. 4, p. 467, abr. 2000). Carlos Roberto Husek esclarece não haver qualquer inconstitucionalidade, pois no máximo teríamos uma condição para o recebimento de uma ação trabalhista em Juízo e, observado esse requisito, o interesse de agir não se concretizaria (HUSEK, Carlos Roberto. Jornal Gazeta, out. 2000. p. 12). Maurício Godinho Delgado também entende que as demandas juslaborativas teriam de se submeter à passagem prévia por tais comissões ou núcleos, desde que existentes na localidade de prestação de serviços; esta passagem despontaria, assim, como verdadeira condição para futura ação trabalhista (DELGADO, Maurício Godinho. Arbitragem, mediação e comissão de conciliação prévia no direito do trabalho brasileiro. LTr: revista legislação do trabalho, São Paulo, v. 66, n. 6, p. 669, jun. 2002).
} 


\section{CAPÍTULO 3. MEDIAÇÃO}

\subsection{Conceito de mediação}

A palavra mediação provém do latim mediatio, que significa intervenção, intercessão, intermediação.

Mediação é um instrumento facilitador de autocomposição do conflito, com a participação de um terceiro, que é escolhido ou aceito pelas partes. Consiste num mecanismo de solução pelas próprias partes que utilizam o mediador como facilitador de um diálogo pacífico, auxiliando as partes no confronto de suas diferenças e de seus possíveis interesses comuns. No âmbito da resolução de conflitos, a mediação é preconizada em geral por uma abordagem multidisciplinar que reforça e permite preservar a relação jurídica dos envolvidos, restabelecendo a comunicação e ampliando a consciência dos atores em conflito.

Assim, a mediação é um processo complexo e multidisciplinar, destinado à busca da identificação do conflito e à retomada do diálogo produtivo entre as partes, voltado ao estímulo de um ambiente harmônico por meio da facilitação de um terceiro imparcial, que desempenha papel não-decisório e centrado na reconstrução da comunicação entre as partes. Seu objetivo é recompor relações pela construção de uma pauta comum de "justiça", que traz uma idéia de eqüidade no sentido de reconhecer igualmente os direitos de cada um e de consolidar uma justiça não apenas na base do direito objetivo e sim de acordo com as necessidades das partes (ainda que não-previstas no direito positivo).

O sentido de justiça não é um critério objetivo, eterno; é o resultado de um consenso social, que pode mudar com o tempo. A mediação tem base no respeito aos interesses das partes e na equiparação de seus valores, o que significa que a razão e o poder são iguais para as partes envolvidas e o que "decide" o conflito é a capacidade de construir acordos benéficos a todos.

A perspectiva da mediação é criar condições para a integração do interesse das partes, permitindo o amplo debate dos aspectos subjetivos que abrangem os envolvidos na dinâmica de seu relacionamento, de forma que os conflitos possam ser 
tratados de modo não-adversarial, possibilitando que eventual acordo seja fruto do comprometimento das partes.

Na mediação, a intervenção do terceiro (mediador), estranho ao conflito, tem o objetivo de proporcionar o ajustamento dos interesses das partes para permitir a resolução da disputa pacificamente, sem proferir sentença, tampouco forçá-las a aceitarem suas sugestões ou recomendações. A ação de mediar possibilita a aproximação dos pontos de vista diversos, ajudando cada parte a entender os interesses do outro e transformando o conflito numa divergência aceitável e passível de solução.

No Manual do Mediador ${ }^{162}$ a mediação encontra-se definida como sendo: "A intervenção destinada a produzir um acordo. Surge como uma intervenção autocompositiva que apresenta às partes a possibilidade de resolver a disputa de acordo com suas necessidades objetivas" (grifo nosso). Tal definição é complementada como sendo a "técnica de manter a negociação entre as partes litigantes sob o controle de uma terceira pessoa, neutra e preparada para superar impasses e continuar negociando, mesmo quando tudo parece estar perdido".

Na verdade a mediação não pode ser vista apenas como um instrumento para produzir um acordo. Ela ultrapassa tal visão simplista, na medida em que possibilita a exteriorização dos aspectos positivos e transformadores do conflito. Seu objetivo é conduzir as partes à construção de suas próprias pontes, de facilitar a comunicação, amenizar a discórdia e prevenir eventuais os impasses. Ou seja, mesmo sem a obtenção de um acordo a mediação pode ser bem-sucedida, por possibilitar uma melhora no relacionamento e, eventualmente, a criação de condições para uma futura composição ${ }^{163}$.

Alfredo Ruprecht entende mediação como um meio de solução dos conflitos coletivos de trabalho onde as partes recorrem a um órgão por elas designado ou instituído oficialmente, o qual propõe uma solução que pode ou não ser acolhida por elas ${ }^{164}$.

\footnotetext{
${ }^{162}$ MANUAL do Mediador. Brasília: MTb, SRT, 1996. p. 11.

${ }^{163}$ Como ressalta Célia Regina Zapparolli (ZAPPAROLLI, Célia Regina. A experiência pacificadora da mediação: uma alternativa contemporânea para a implementação da cidadania e da justiça. In: MUSZKAT, Malvina Ester (Org.). Mediação de conflitos: pacificando e prevenindo a violência. São Paulo: Summus, 2003. p. 66), “...o que realmente importa na mediação é a garantia de sua qualidade, resguardando-se a equidade e o respeito entre as partes, a escuta e a neutralidade do mediador, entre outros aspectos específicos. E, mesmo que não se chegue a uma solução definitiva, a mediação sempre abre canal à possibilidade de reformulação e mudança ética e cultural".

${ }^{164}$ RUPRECHT, Alfredo. op. cit., p. 212. No mesmo sentido é a definição de Alonso García, citada por Ruprecht, que entende que a mediação "é a instituição jurídica destinada à atuação de pretensões - ou à solução de conflitos - ante um órgão designado pelas partes ou instituído oficialmente, chamado a formular uma proposta ou recomendação que carece de valor decisório"
} 
Esclarece ainda que a proposta do mediador não tem força compulsiva, mas simplesmente de recomendação e a vontade das partes sempre prevalece. Por fim, ressalta que o efeito da mediação é de índole moral, não necessariamente jurídico, pois $o$ mediador não leva em conta o aspecto meramente jurídico e se o faz não o realiza em forma primordial ${ }^{165}$.

Maurício Godinho Delgado, conceitua mediação como técnica de auxílio à resolução dos conflitos, onde um terceiro realiza o papel de aproximar as partes, ponderando os pontos de divergência e aproximação e sugerindo um final pacificatório. ${ }^{166}$

Para Maria de Nazareth Serpa, a mediação representa um processo informal e voluntário, onde um terceiro neutro auxilia os envolvidos, sem interferir em suas decisões, ajudando-os, através da neutralização de emoções e formação de opções, na comunicação e na negociação de acordos ${ }^{167}$.

Assim, a mediação tem por pressuposto a participação de um terceiro, indiferente ao conflito, que procura "contornar" as dificuldades das partes para solucionar o litígio. Como meio alternativo de solução de litígios, ela representa o oposto das regras que procuram compor conflitos por meio do Poder Judiciário, vez que as partes, ao possuírem uma maior participação e controle do conflito, são co-responsáveis por suas decisões.

Ao buscar a resolução do conflito pelas próprias partes, que recebem auxílio do mediador para administrá-lo, a mediação representa uma proposta transformadora do conflito. Lília Maia de Morais também ressalta que a liberdade apresentada aos envolvidos para a solução de seus próprios conflitos colabora não apenas com a sua solução, mas também com a sua prevenção ${ }^{168}$.

Em razão dessa abordagem do conflito, a participação das partes deve ser ativa e de forma colaborativa e de boa-fé, expondo suas vontades de maneira livre e

\footnotetext{
${ }^{165}$ RUPRECHT, Alfredo. op. cit., p. 211.

${ }^{166}$ DELGADO, Maurício Godinho. op. cit., p. 666.

${ }^{167}$ SERPA, Maria de Nazareth. Teoria e prática da mediação de conflitos. Rio de Janeiro: Lúmen Júris, 1999. p. $90-91$.

${ }^{168}$ SALES, Lilia Maia de Morais. Justiça e mediação de conflitos. Belo Horizonte: Del Rey, 2004. p. 24. Para a autora, "a mediação apresenta-se como uma forma amigável e colaborativa de solução das controvérsias que busca a melhor solução pelas próprias partes. É um procedimento em que e através do qual uma terceira pessoa age no sentido de encorajar e facilitar a resolução de uma disputa, evitando antagonismos, porém sem prescrever a solução. As partes são as responsáveis pela decisão que atribuirá fim ao conflito. A mediação, quando oferece liberdade às partes de solucionar seus conflitos, agindo como meio facilitador para tal, passa não somente a ajudar na solução de conflitos, como também a preveni-los".
} 
consciente, num ambiente de confidencialidade que possibilite a tomada de decisão de maneira responsável.

A mediação é, assim, um mecanismo não-adversarial onde um terceiro imparcial, sem poderes decisórios, ajuda as partes a encontrarem um ponto de harmonia do conflito de forma cooperativa. O mediador inspira os envolvidos a identificarem os pontos principais do problema, a adaptarem seus interesses aos da parte contrária e a explorarem possibilidades de ajustes que transcendam o tema da disputa, produzindo, assim, uma visão produtiva para todos. Ela não possui formas rígidas, mas, como um mecanismo de apoio, é caracterizada por métodos elaborados e focados na relação. Como veremos adiante, os modelos focados no acordo (mediação satisfativa) priorizam o problema concreto e buscam o acordo. Os modelos focados na relação (circular narrativo e transformativo) priorizam a transformação do padrão da relação.

Ela é recomendada, principalmente, nas hipóteses em que as partes possuem uma relação que se perpetua no tempo. Na mediação as partes conservam para si o controle sobre o resultado do conflito e compartilham a responsabilidade por sua existência e solução.

Ordinariamente, a mediação é consensual. Ou seja, as partes não são obrigadas a utilizar um mediador para a composição de seus conflitos. Há, no entanto, a mediação obrigatória, que pode ser por força de lei que a institua como condição ao exercício do direito de ação (sistema argentino) ou por determinação judicial (sistema norte-americano), conforme será adiante exposto.

\subsection{Objetivos}

Uma das idéias básicas da mediação é a da alteridade, isto é, colocar o outro no lugar do ser. A tendência natural num conflito é colonizar a outra parte; na mediação, o outro não é um objeto para uma parte. A alteridade dá a capacidade de apreender o outro na plenitude da sua dignidade, dos seus direitos e, sobretudo, das suas diferenças. 
Nas lições de Luis Alberto Warat, a mediação como ética da alteridade tenta recuperar o respeito e o reconhecimento da integridade e da privacidade do outro ${ }^{169}$. O mesmo autor prossegue dizendo que o que se busca com a mediação é uma reconstrução do conflito, com vistas a superar as divergências entre as partes e construir identidades culturais, o que exige sempre a presença de um terceiro que cumpra as funções de escuta e implicação ${ }^{170}$.

Adotaremos a metodologia utilizada por Lília Maia de Morais Sales ${ }^{171}$, que destaca quatro objetivos da mediação: solução de conflitos (pela visão positiva do conflito e da participação ativa e responsável das partes pela comunicação), prevenção dos conflitos, inclusão social (pela conscientização de direitos e acesso à justiça) e paz social.

\subsubsection{Solução de conflitos}

O objetivo principal da mediação é que as partes cheguem a um consenso satisfatório, mediante a exploração de suas necessidades, prioridades e interesses subjacentes dos envolvidos no conflito. A comunicação e a participação dos envolvidos são imprescindíveis para a interação e busca de um acordo satisfatório. A mediação possibilita tal comunicação, minimizando as diferenças entre as partes.

É necessário que se tenha uma visão positiva do conflito para facilitar a comunicação entre as partes. Se as partes utilizarem o impasse como um momento de reflexão e, portanto, de transformação, o conflito torna-se algo positivo. A mediação cria condições para convivência com as diversidades, possibilitando a realização de soluções pacíficas e acordos mutuamente compensadores.

Dessa maneira, a mediação possibilita que os envolvidos passem a encarar de forma positiva o conflito, cooperando com uma convivência futura satisfatória entre as partes. Assim, o sucesso da mediação dependerá da transformação ocorrida entre

\footnotetext{
${ }^{169}$ WARAT, Luis Alberto. O ofício do mediador. Florianópolis: Habitus, 2001. v. 1. p. 70.

${ }^{170}$ Id. Em nome do acordo: a mediação no direito. In: (Org.). Ecologia, psicanálise e mediação. Buenos Aires: Associação Latino- Americana de Mediação, Metodologia e Ensino do Direito, 1999. p. 1112. Para o autor, "a mediação seria um salto qualitativo para superar a condição jurídica da modernidade, baseada no litígio e apoiada em um objetivo idealizado e fictício como é o de descobrir a verdade, que não é outra coisa que a implementação da cientificidade como argumento persuasivo; (...). Um juiz que decide a partir do sentido comum teórico dos juristas, a partir do imaginário da magistratura, um lugar de decisão que não leva em conta o fato de que o querer das partes pode ser diferente do querer decidido".

${ }^{171}$ SALES, Lilia Maia de Morais. op. cit., p. 27.
} 
os mediados, constituindo importante ferramenta para aprimoramento do relacionamento entre eles ${ }^{172}$.

No momento em que a mediação objetiva substituir a lógica ganhadorperdedor do enfrentamento judicial, sua dinâmica na prática da negociação possibilita o conhecimento dos fatos e a real extensão das dificuldades que envolvem o conflito. Ao contrário do que ocorre no Poder Judiciário, o mediador desempenha um papel ativo, com notável grau de iniciativa, não apenas porque sua conduta objetiva a aproximação das partes conflitantes, mas também porque apresenta alternativas sem qualquer caráter impositivo para apreciação dos interessados.

A mediação não exige a fixação prévia de uma posição nem a formulação de um pedido; os envolvidos discutem os problemas que os envolvem com a preocupação de fixar seus interesses e não de determinar suas posições específicas. Ainda que as partes não cheguem à mediação com tal discernimento, caberá ao mediador alterar o rumo do diálogo, orientando-os para o campo de revelação dos problemas e dificuldades e compreensão dos interesses subjacentes ${ }^{173}$.

Eventual acordo ${ }^{174}$ realizado na mediação é consciente, responsável, o que garante a sua efetividade, já que as partes, com o auxílio de um mediador, resolvem conjuntamente a questão após discussão aberta e colaborativa de todos os fatores que envolvem os problemas, não se limitando à abordagem jurídica, mas também levando em conta os aspectos sociológicos e psicológicos do conflito. Amplia-se, como consequiência, a interação entre a realidade social e o ordenamento jurídico; o critério do "justo" não está apenas relacionado ao direito positivo; está ligado à satisfação dos interesses das partes envolvidos na questão.

\footnotetext{
${ }^{172}$ TEIXEIRA FILHO, João de Lima; SÜSSEKIND, Arnaldo; MARANHÃO, Délio; VIANNA, Segadas. op. cit., p. 185. Na visão de João de Lima Teixeira Filho, a mediação "visa a progressiva redução do espaço faltante para o atingimento do ponto de equilíbrio em torno do qual o consenso das partes se perfaz, livrando-os do impasse ou retirando-os da posição de conflito".

${ }^{173}$ CALMON, Petrônio. op. cit., p. 126.

${ }^{174}$ Entende-se como tal a produção de um consenso voltado para as futuras relações das partes envolvidas. A elaboração do acordo seria a etapa final da mediação e representa um contrato, onde é necessária a identificação das partes e do objeto do acordo, a definição das obrigações pactuadas, as diretrizes de como deverão ser cumpridas tais obrigações e as conseqüências do não-cumprimento.
} 


\subsubsection{Prevenção}

Outro aspecto da mediação é o fato de que suas estratégias objetivam, além da resolução de conflito, a prevenção e a aprendizagem de novas maneiras de resolução de conflito, promovendo um ambiente propício à colaboração e possibilitando que relações continuadas perdurem de forma positiva.

Como ressalta Lília Maia de Morais Sales, o fato de uma parte obter uma sentença judicial favorável não significa que o conflito esteja resolvido, já que muitas vezes os problemas revelados são apenas os aparentes, os expostos, não os reais, que normalmente continuam a existir. Numa mediação, o mediador colabora para a solução efetiva da controvérsia, criando muitas vezes vínculos entre as partes envolvidas, que até então eram inexistentes. Com tal conduta, compreende-se o impasse real e daí passa a prevenir a má administração de outros futuros ${ }^{175}$.

Ainda que não seja possível um acordo, as sessões de mediação tendem a desenvolver um ambiente mais pacífico e de colaboração entre as partes, possibilitando a prevenção dos conflitos. No entendimento de Christopher W. Moore ${ }^{176}$, a mediação pode estabelecer ou fortalecer relacionamentos de confiança e respeito entre as partes ou encerrar relacionamentos de uma maneira que minimize os custos e os danos psicológicos. Assim, na medida em que oferece às partes a liberdade de solucionar seus próprios conflitos, a mediação passa a prevenir os conflitos.

Para Jean-François Six, a mediação propõe a dignidade da distinção: ela respeita a individualidade das partes, incentivando a troca de oposições e favorecendo a ligação e o contato entre elas. Ela possibilita, assim, que do diálogo impulsionado pelo mediador sobrevenha uma solução que não será "nem a solução unilateral do primeiro, nem a solução unilateral do segundo, mas uma saída original realizada por um e outro juntos, uma saída que não pertença a nenhum dos dois propriamente, mas aos dois, como uma criança que nasce de dois pais" ${ }^{\prime 17}$.

Antonio Rodrigues de Freitas ressalta que num processo típico de mediação o mediador, na maioria das vezes, atua não apenas como um simples facilitador

\footnotetext{
${ }^{175}$ SALES, Lilia Maia de Morais. op. cit., p. 30.

${ }^{176}$ MOORE, Christopher. O processo de mediação. Trad. Magda França Lopes. Porto Alegre: Ed. Artmed, 1998. p. 28.

${ }^{177}$ Id. Ibid., p. 7.
} 
da negociação; ele intervém na relação intersubjetiva das partes objetivando promover a transformação do conflito num processo de verdadeira construção comum de parâmetros de entendimento reconhecidos pelas partes como justos ${ }^{178}$.

Assim, o processo de mediação, na medida em que possibilita a visão positiva dos conflitos e incentiva o diálogo e a comunicação dos envolvidos, colabora com a conscientização dos direitos e deveres, além de aumentar a responsabilidade de cada uma delas para a concretização desses direitos, facilitando a obtenção e o cumprimento de eventual acordo e, conseqüente, prevenindo a existência de novas desavenças.

\subsubsection{Inclusão Social}

Como um processo que possibilita, com o auxílio do mediador, a participação ativa das partes para a resolução de seus problemas, a mediação viabiliza uma maior consciência de seus direitos e deveres e, portanto, maior informação e envolvimento nas questões sociais. A participação ativa dos cidadãos na resolução de seus próprios conflitos resulta no desenvolvimento do sentimento de autonomia e de comando sobre os problemas reais $^{179}$.

Como já desenvolvido anteriormente, o efetivo acesso à justiça é fundamental nas constituições político-jurídicas dos Estados Democráticos de Direito. O fundamento político da mediação refere-se ao aspecto da participação popular na administração da justiça, pela colaboração do corpo social nos procedimentos da mediação e conciliação. Assim, a função de leigos nessa função conciliatória confere a possibilidade de participação popular no âmbito da justiça, configurando meio de intervenção popular na administração da justiça ${ }^{180}$.

\footnotetext{
${ }^{178}$ FREITAS JÚNIOR, Antonio Rodrigues. op. cit., p. 233.

${ }^{179}$ VOESE, Ingo. Mediação dos conflitos como negociação de sentidos. Curitiba: Juruá, 2005. p. 15. Aspecto fundamental referente à liberdade dos cidadãos é ressaltado pelo autor: "a lei, enquanto discurso, possibilita, mas também limita a pluralidade de sentidos, devendo, por isso, poder garantir uma sociabilidade sem que os indivíduos sejam tolhidos de exercer a autonomia, a cidadania, a subjetividade, enfim. A liberdade que garantirá ao indivíduo ser singular e social ao mesmo tempo, torna-se, pois, um desafio para os que trabalham com a lei: necessitam de uma postura teórica que possa fazer da lei uma guardiã da liberdade como um bem coletivo que, no entanto, não deve anular a autonomia".

${ }^{180}$ GRINOVER, Ada Pelegrini. Os fundamentos da justiça conciliativa, cit., p. 5.
} 
A mediação é um instrumento importante para o processo de democratização $^{181}$, que necessita de políticas que impliquem a participação ativa dos cidadãos. Ela é um veículo do exercício da cidadania ativa, por possibilitar que as partes exerçam sua autonomia para tratar e administrar seus conflitos, identificando a causa do problema e o meio mais adequado para solucioná-lo. Acarreta, portanto, a inclusão social, na medida em que transforma a cultura política de sujeição na cultura política de participação.

\subsubsection{Paz Social}

A "Paz" que se objetiva pela mediação difere da "Paz" autoritária preconizada pelo Estado Novo, que partia do pressuposto que os conflitos sociais pudessem afetar a sociedade, o que justificou o desenvolvimento de minuciosa regulamentação para inibir a manifestação destes conflitos. Difere, ainda da antiga visão da justiça e do processo que, como observa Cândido Rangel Dinamarco ${ }^{182}$, é resultante do Estado liberal oitocentista e do sistema processual das primeiras décadas deste século, e traz a idéia de que o Estado cumpre sua função de busca do bem comum e da paz social mediante o cumprimento da lei pelo exercício da jurisdição ${ }^{183}$.

A tendência atual é de abandono das fórmulas exclusivamente jurídicas para o exercício amplo da jurisdição, com vistas à busca de procedimentos que sejam condizentes com a proteção dos direitos e com a administração dos conflitos. Preconiza-se a busca do interesse comum e do respeito entre os cidadãos e nesse sentido, a "Paz" não

\footnotetext{
${ }^{181}$ Quando se fala em democracia, fala-se em participação, que resulta cidadania ativa, sujeito e exercício de direitos e deveres. A democracia exige atuação do cidadão e, portanto, uma cultura política de participação. A inclusividade - participação ativa do cidadão na vida social - é fundamental para o processo de democratização. Assim, o exercício da autonomia de vontade das partes proporciona a inclusão do cidadão na vida social.

${ }^{182}$ DINAMARCO, Cândido Rangel. A instrumentalidade do processo, cit., p. 189.

${ }^{183}$ SADEK, Maria Tereza. Judiciário: mudanças e reformas. Estudos Avançados, São Paulo, v. 18, n. 51, p. 79-101, maio/ago. 2004. Segundo a autora, tornou-se dominante a idéia de que Poder Judiciário seria incapaz de responder à crescente demanda por justiça. "Nas análises mais impressionistas sustenta-se que as instituições judiciais ficaram perdidas no século XVIII ou, na melhor das hipóteses, no XIX, enquanto o resto do país teria adentrado nos anos 2000 (...) A situação brasileira recente difere de todo o período anterior em pelo menos dois aspectos: 1. a justiça transformou-se em questão percebida como problemática por amplos poderes da população, da classe política e dos operários do Direito, passando a constar da agenda de reformas; 2 . tem diminuído consideravelmente o grau de tolerância com a baixa eficiência do sistema judicial e, simultaneamente, aumentando a corrosão no prestígio do Judiciário" .
} 
depende apenas do Estado, e sim da responsabilidade dos atores sociais, que, num conflito, devem reconhecer e qualificar a pretensão alheia como supostamente justa.

A mediação trabalha com a lógica da eqüidade, da alteridade, da diversidade, da complexidade e dos poderes compartilhados. Ela tenta romper com os paradigmas fixos, possibilitando uma re-construção do conflito. Na medida em que pretende tratar os conflitos de uma maneira não-adversarial, ela estimula o desenvolvimento da solidariedade e da tolerância entre as partes envolvidas.

Na visão de Lilia Maia de Moraes Sales ${ }^{184}$, a mediação transcende a solução do litígio, na medida em que exterioriza a visão positiva e transformadora do conflito, facilitando o diálogo entre os indivíduos, prevenindo controvérsias e contribuindo para a inclusão e a paz social. Sua base é a comunicação, sendo que o diálogo solidário possibilita a construção de soluções pelas partes envolvidas no conflito, favorecendo o sentimento de inclusão.

Percebe-se, portanto, que por não se limitar aos aspectos manifestos do conflito, a mediação possibilita que os envolvidos passem a encarar os conflitos de forma positiva, não os negando nem utilizando subterfúgios para fugir deles. Tal mudança de visão faz com que as próprias partes vislumbrem caminhos a um futuro que permitirá estabelecer novos relacionamentos e possibilidades, alcançando-se melhor convivência futura e contribuindo para o sentimento de inclusão e paz no meio em que convivem.

\subsection{Vantagens da mediação}

As vantagens da mediação já foram indiretamente retratadas no decorrer do presente trabalho. Elucidaremos de maneira prática e direta algumas das vantagens que a mediação possibilita para as partes, estabelecendo um singelo comparativo em relação ao conflito levado ao Poder Judiciário.

Para as partes, a mediação traz inúmeras vantagens, a saber:

- Propicia que as partes analisem questões de fundo, emocionais, que não seriam discutidas em juízo, pois o ambiente onde se desenvolve a mediação, em conjunto com as técnicas empregadas e os objetivos perseguidos pelas partes e do

\footnotetext{
${ }^{184}$ SALES, Lilia Maia de Morais. op. cit., p. 14.
} 
mediador, possibilitam a abordagem de forma mais ampla dos aspectos sócio-econômicopsicológicos que interferem nas relações e fazem parte do conflito;

- Soberania das partes: possibilita que as partes alcancem a própria solução, sem qualquer tipo de imposição, o que torna as relações mais reais e duradouras;

- Facilita a negociação e o diálogo entre as partes, evitando a incerteza de um julgamento e a existência de ganhadores e perdedores;

- Garantia de uma solução mais rápida e econômica, em razão da informalidade;

- Garantia de privacidade e sigilo: a confidencialidade é um dos princípios da mediação. Significa que as informações obtidas pelo mediador ou pelas partes serão mantidas dentro do programa da mediação. Todos os fatos e circunstâncias discutidos são garantidos pelo sigilo, o que proporciona um ambiente de segurança e respeito, fundamental para um diálogo cooperativo;

- Transformação e melhoria no relacionamento entre as partes: como já ressaltado em diversas oportunidades, a mediação possibilita a reconstrução e a continuidade do relacionamento entre as partes;

- Possibilita que os acordos sejam duradouros, uma vez que as partes reconhecem sua participação de forma consciente;

- Transferência de aprendizagem - os benefícios com essa nova maneira de ver o conflito podem ser utilizados em outras disputas.

Em relação ao Judiciário, a mediação traz as seguintes vantagens:

- possibilita a solução do litígio de uma maneira mais rápida;

- aumenta a credibilidade entre os jurisdicionados, pois os serviços prestados serão mais rápidos e com maior grau de satisfação;

- na medida em que as partes são as principais responsáveis pela resolução do conflito, promove-se o interesse pela resolução alternativa, favorecendo as relações continuadas. A mediação exalta a participação dos envolvidos, sem o apego ao direito positivo. O intuito é ajudar no relacionamento como um todo, proporcionando a possibilidade de continuidade pacífica da relação; 
- diminuição da reincidência dos litígios, pois no processo de mediação existe a preocupação em reconstruir os vínculos entre as partes, transformar e prevenir conflitos $^{185}$.

- no Judiciário o conflito é decidido de acordo com os enunciados pelas partes, atendendo às formalidades do pedido. A mediação não exige a fixação prévia de uma posição nem a formulação de um pedido. Os envolvidos revelam seus interesses, sem a preocupação de fixar posições rígidas, o que favorece uma maior compreensão do conflito, que é encarado como algo não necessariamente maligno ou prejudicial.

\subsection{Princípios}

A mediação não possui um procedimento fixo, determinado, como ocorre nos processos judiciais. Tal procedimento caracteriza-se pela simplicidade, informalidade, economia e celeridade, na busca, sempre que possível, do acordo entre as partes litigantes. O mediador procura aproximar as partes para que estas busquem a solução de seus conflitos. Podemos apontar alguns princípios da mediação, que devem sempre estar presentes:

- Voluntariedade das partes: reconhece o direito de as partes optarem e participarem livremente no processo da mediação ${ }^{186}$. Trata-se de uma construção em conjunto dos envolvidos, que adotam o procedimento da mediação para a resolução de seus conflitos e são livres para decidir e resolver o conflito dentro desse procedimento.

- Não competitividade/ não adversariedade e boa-fé - o conflito deve ser abordado de maneira positiva e de forma a não incentivar a competição. As partes não competem, e sim cooperam para que ambas sejam vencedoras. A comunicação e a cooperação entre as partes devem ser estimuladas e a boa-fé deve sempre pautar todo esse exercício. Como referido anteriormente, o princípio da boa-fé é baseado na confiança

\footnotetext{
${ }^{185}$ Segundo Warat (WARAT, Luis Alberto. O ofício do mediador, cit., p. 79), é o “ (...) caráter transformador dos sentimentos que, por graça da mediação, pode ocorrer nas relações sentimentalmente conflituosas, o que é ignorado no procedimento judicial e nos outros procedimentos alternativos de resolução dos conflitos judiciais.”

${ }^{186}$ MICHELON, Regina Maria Coelho. A mediação dos conflitos trabalhistas. In: OLIVEIRA, Ângela. Mediação: métodos de resolução de controvérsias. São Paulo: LTr, 1999. p. 158. Segundo a autora, "as partes devem estar livres para escolher a mediação como processo para solucionar o conflito e livres para escolher o mediador em que depositem confiança".
} 
recíproca, que implica na clareza e lealdade dos propósitos revelados pelas partes. Representa o dever ético de agir com honestidade e fidelidade.

- Poder de decisão das partes - como ressaltado em diversas oportunidades, o poder de decisão cabe sempre às partes. O mediador apenas facilita a comunicação, auxiliando as partes na resolução de seus conflitos, mas não os decide. Tal princípio reconhece que as partes têm a faculdade, o direito e o poder de definir suas questões, sendo responsáveis pelos termos de qualquer acordo que seja celebrado.

- Imparcialidade - é o princípio que garante o direito das partes a um processo de mediação justo e eqüitativo e à participação de um terceiro imparcial, escolhido ou aceito por estas, que se abstenha de todo favoritismo ou juízo de valor e possibilite a igualdade de oportunidade do diálogo entre os envolvidos. A imparcialidade confere legitimidade ao procedimento e é corolário do princípio de igualdade das partes. Christopher Moore $^{187}$ sugere uma declaração de imparcialidade e neutralidade, identificando a imparcialidade como isenção em relação às questões tratadas e neutralidade como isenção em relação às partes.

- Competência/idoneidade do mediador - o mediador deverá ter capacidade para mediar a controvérsia, além de ser diligente, cuidadoso e capaz de compreender a dinâmica do conflito. Ele deverá possibilitar o diálogo construtivo entre as partes, sem impor qualquer solução. Sua idoneidade é condição necessária à credibilidade do procedimento, não devendo existir qualquer predileção por uma das partes, nem posicionamento prévio sobre as questões debatidas.

- Informalidade do processo - inexistem regras rígidas no processo de mediação, o que permite uma maior descontração, garantindo a comunicação ilimitada para que as partes exerçam flexibilidade ao informar suas preocupações e prioridades básicas em relação à questão discutida.

- Confidencialidade - o princípio da confidencialidade já foi definido no item acima, mas é importante ressaltar que tal princípio não está restrito ao processo de mediação, vez que as partes e o mediador se comprometem a resguardar o que foi dito ou apresentado nas sessões de mediação mesmo após o término do procedimento. Assim, todas as comunicações ocorridas entre partes e mediadores devem ser resguardadas pelo

\footnotetext{
${ }^{187}$ MOORE, Christopher. op. cit., p. 174-175.
} 
sigilo, não se admitindo que o mediador seja arrolado como testemunha em eventual processo judicial.

\subsection{Formas de mediação}

Podemos observar a existência de três formas de mediação: a privada, institucionalizada ou relacionada a algum órgão público e a comunitária.

Na mediação privada, os serviços são prestados por mediadores independentes ou câmaras de conciliação organizadas por estatutos próprios. O pedido de instalação é feito por livre e espontânea vontade dos participantes, que resolvem tentar um acordo e desenvolver o procedimento por esta maneira. $\mathrm{O}$ consentimento é condição sine qua non para o início do processo de mediação. Funda-se, assim, no princípio da voluntariedade.

Nos serviços de mediação institucionalizados ou relacionados a órgãos públicos, a mediação pode ser de natureza administrativa ou judicial. Exemplo de mediação de natureza administrativa é a que ocorre perante os Ministérios do Trabalho. No tocante à mediação no âmbito do processo judicial, referido órgão pode sugerir ou recomendar que as partes compareçam a reuniões de mediação como parte do procedimento judicial $^{188}$.

A mediação comunitária visa desenvolver entre a população valores, conhecimentos e comportamentos destinados ao fortalecimento de uma convivência pacífica, contribuindo para um melhor entendimento de respeito e tolerância e para um tratamento adequado para as questões que perturbam a paz. É utilizada como ferramenta de acesso à justiça para a população de baixa renda no Brasil, a partir da sua implementação por meio de um projeto social, conduzido nos limites de uma organização nãogovernamental. O Programa de Justiça Comunitária, coordenado pelo Tribunal de Justiça do Distrito Federal e Territórios, é exemplo de mediação comunitária.

\footnotetext{
${ }^{188}$ Exemplos de tais serviços podem ser constatados pelo trabalho realizado pelo Projeto Íntegra Gênero e Família, que, em parceria com a Instituição Pró-Mulher, Família e Cidadania, possibilitou a instalação de núcleos de mediação interdisciplinar em crimes processados pela Lei 9099/95, em conflitos de gênero e família.; pelo Projeto "Porto Alegre" - implementado em outubro de 1993, para aconselhamento familiar junto ao Fórum Central de Porto Alegre; pelo NAF - Núcleo de Atendimento Familiar do Judiciário instalado no Fórum Central de Porto Alegre em 1997, que tem como objetivo contribuir para o encerramento rápido e adequado dos processos das Varas de Família e Sucessão, Infância e Juventude, bem como os casos remetidos pelo Projeto Conciliação.
} 


\subsection{Métodos de mediação}

São diversos os métodos ou técnicas utilizadas para estabelecer ou conduzir o procedimento da mediação. Não se pode falar em modelo certo ou errado, sendo que alguns são desenvolvidos pelos próprios mediadores, sem que se conheça a maneira como são praticados. O modelo estabelecerá alguns aspectos do procedimento de mediação. Há modelos focados no acordo (mediação satisfativa), que priorizam o problema concreto e objetivam o acordo e modelos focados na relação (circular-narrativo e transformativo), que priorizam a transformação da relação através da comunicação, da apropriação e do reconhecimento. Apresentaremos a seguir a classificação adotada por Marinès Suares ${ }^{189}$ :

- Modelo Tradicional-linear (Harvard) - decorre da aplicação do método da negociação cooperativa por um terceiro que auxilia as partes a descobrirem seus interesses e integrá-los em soluções de ganhos mútuos. É o mais importante no estudo da negociação, pois trabalha os caminhos possíveis para vencer cada obstáculo, introduzindo conceitos essenciais que foram incorporados à mediação, como: 1. noções de posições e interesses; 2. estímulo a soluções criativas; 3. avaliação objetiva das propostas apresentadas. Tem como objetivo principal a solução do problema pela obtenção de um acordo nos interesses das próprias partes, respeitando-se sempre a autonomia das partes. A comunicação é entendida no sentido linear, o mediador é imparcial e sua meta é o acordo. A principal função do mediador é facilitar o diálogo entre as partes, estimulando-as a propor soluções criativas, sem expressar sua convicção pessoal sobre os possíveis resultados de um eventual processo, nem sugerir ou recomendar os possíveis acordos.

Os aspectos subjetivos dos conflitos podem até ser abordados, mas são afastados da discussão principal, para que os aspectos objetivos possam ser tratados diretamente.

- Modelo Transformador de Bush y Folder - a obtenção do acordo não é o objetivo principal a ser buscado. As inter-relações entre as partes são consideradas em primeiro plano e a mediação objetiva a revisão das relações, a transformação da relação existente entre os envolvidos a partir do fortalecimento da autodeterminação e do

\footnotetext{
${ }^{189}$ SUARES, Marines. Mediación: conducción de disputas, comunicación y técnicas. Buenos Aires: Piados, 1997. p. 41-66.
} 
reconhecimento do outro. A comunicação tem um aspecto relacional e o acordo é secundário e invocado como um destaque mais retórico do que finalístico ${ }^{190}$. A causalidade é circular (incorpora novos paradigmas, não há uma causa única que determina um determinado resultado) e as partes são agentes e responsáveis pelas decisões. A meta principal é modificar a relação entre as partes para que possam alcançar, por elas próprias, uma solução satisfatória para ambas; as partes são responsáveis por suas próprias ações. $\mathrm{O}$ acordo surgirá naturalmente quando as pessoas envolvidas possam dialogar.

- Circular-narrativo (Sara Cobb) - a comunicação é o elemento chave para o seu desenvolvimento. Tem como meta fomentar a reflexão e a construção de uma reflexão crítica sobre a história das partes. Considera que não existe verdade ou mentira nas narrativas dos conflitos e a finalidade é transformar a história que as partes trazem inicialmente. Cada conflito terá suas características próprias e específicas dentro do contexto em que as partes estão envolvidas. Cada história é tomada como uma narrativa rígida a ser mudada através do reconhecimento da pluralidade de elementos intervenientes nos conflitos. Não há uma causa única; adota-se um sistema que aumenta as diferenças (o mediador provoca as manifestações das partes e faz com que elas apresentem a narrativa mais ampla do conflito, permitindo a exposição livre da história segundo os significados das próprias partes). As perguntas circulares são utilizadas para que as partes digam o que pensam a respeito das opiniões e expectativas da outra parte, possibilitando a confrontação das versões no caminho da construção de um discurso aproximativo.

O conhecimento das diversas técnicas e modelos são essenciais para a atividade do mediador e para o aprimoramento da própria mediação. É um equívoco limitar-se a apenas um modelo, pois a mediação deve ser dinâmica e incluir todas as correntes de pensamento, desde que enquadradas nos princípios destacados no tópico anterior.

\footnotetext{
${ }^{190}$ WARAT, Luis Alberto. O ofício do mediador, cit., p. 84. O autor sinaliza que a corrente transformadora "consiste na visualização do conflito como uma oportunidade para o oferecimento às partes da possibilidade de uma melhora na qualidade de vida, para o encontro consigo mesmo e para a melhora na satisfação dos vínculos".
} 


\subsection{Diferenças com outros meios alternativos de composição dos conflitos}

A procura por métodos alternativos para a resolução dos conflitos tem se intensificado bastante, sendo variados os mecanismos de solução utilizados para tal finalidade. Como já dissemos, as principais alternativas para a solução dos conflitos são a negociação, a conciliação, a mediação e a arbitragem, que possuem características próprias que os distinguem uns dos outros. A doutrina aponta as três primeiras como modalidades de autocomposição e a última como forma heterocompositiva de solução de conflito.

Vale esclarecer que a autocomposição é definida como "forma de solução, resolução ou decisão do litígio por obra dos próprios litigantes sem intervenção vinculativa de terceiro" ${ }^{\prime 191}$. Ou seja, a disputa é resolvida porque as partes encontram uma forma de adequação dos interesses originalmente contrapostos. Já na heterocomposição, a resolução é definida a partir de valores impostos por um terceiro (juiz ou árbitro).

A negociação é a forma mais antiga de resolução de disputas. Nela as partes se relacionam, com ou sem a ajuda de uma parte neutra, ou com a ajuda de facilitadores de cada lado, com o objetivo de construir um acordo. Maria Inês Correia de Cerqueira César Targa define negociação como a atividade não-adversarial de solução de conflitos, desenvolvida pelas próprias partes interessadas, sem o auxílio de terceiros, que dura um determinado período e se destina à construção de um acordo total, parcial ou temporário $^{192}$.

Na negociação, o negociador representa os interesses de uma das partes. O mediador, ao contrário, não se encontra envolvido e procura acompanhar a reflexão das duas partes, permitindo-lhes encontrar um acordo. Ele não atua como um simples facilitador da negociação; ele intervém na relação intersubjetiva, com o objetivo de promover sua transformação, "num processo de verdadeira construção comum de parâmetros de entendimento reconhecidos pelas partes como justos" ${ }^{193}$.

Os conceitos de conciliação e mediação nem sempre são diferenciados. Os dois institutos priorizam a autonomia das partes, com vistas a uma solução conciliada.

\footnotetext{
${ }^{191}$ AZEVEDO, André Gomma. Estudos em arbitragem, mediação e negociação, cit., p. 138.

${ }^{192}$ TARGA, Maria Inês Correia de Cerqueira César. Mediação em juízo. São Paulo: LTr, 2004. p. 113.

${ }^{193}$ FREITAS JÚNIOR, Antonio Rodrigues. op. cit. p. 233.
} 
Para Lília Maia de Moraes Sales ${ }^{194}$, o objetivo na conciliação é o acordo; as partes, ainda que adversárias, devem chegar a um acordo para evitar um processo judicial. Na mediação, "as partes não devem ser entendidas como adversárias e o acordo é conseqüência da real comunicação entre as partes”.

Christopher Moore esclarece que na prática a conciliação é um processo contínuo que ocorre durante toda a negociação e mediação e que "a conciliação é o componente psicológico da mediação, em que a terceira parte tenta criar uma atmosfera de confiança e cooperação que promova relacionamentos positivos e conduza às negociações",195.

André Gomma de Azevedo ${ }^{196}$, ao tratar dos conceitos de conciliação e mediação, esclarece que os dois conceitos são adotados como sinônimos relativos por não se produzirem efeitos jurídicos distintos decorrentes da utilização desses termos. Cabe registrar que essa terminação tem se mostrado como tendência moderna já adotada em diversos países como o Canadá, o Reino Unido, e a Austrália (Singer, L.R. Setting Disputes: Conflict Resolucion in Business, Families, and the Legal System. Couder, CO: Ed. Westview, 1990). No contexto brasileiro, quando o legislador buscou inspiração no direito comparado para incorporar ao nosso ordenamento jurídico estrutura semelhante aos small claims courts norte-americanos, introduziu com os juizados especiais (Lei $\mathrm{n}^{\circ}$ 9.099/95) o que nos EUA denominava-se mediation (mediação) usando o termo “conciliação", possivelmente por ser este o termo utilizado no Brasil desde as ordenações Filipinas até a Constituição Federal atual. Ressalte-se que nos EUA o termo "mediation" envolve desde a mediação facilitada ${ }^{197}$ até o que chamamos de mediação transformadora e o vocábulo conciliation equivale ao que chamamos de arbitramento.

\footnotetext{
${ }^{194}$ SALES, Lilia Maia de Morais. op. cit., p. 38. Para a autora, "na conciliação o mediador sugere, interfere, aconselha. Na mediação, o mediador facilita a comunicação, sem induzir as partes a um acordo".

${ }^{195}$ MOORE, Christopher. op. cit., p. 145.

${ }^{196}$ AZEVEDO, André Gomma. Processos construtivos: orientações prospectivas nos Juizados Especiais. Revista dos Juizados Especiais, Brasília, n. 16, jan./jun. 2004.

${ }^{197}$ Entende-se por mediação facilitada o novo modelo de mediação que valoriza e estimula a atuação avaliativa do mediador, que passa a ter as funções de alertar as partes sobre os possíveis resultados da demanda e de sugerir possíveis soluções de acordo e, em caso de impasse, destacar os possíveis resultados da demanda. A mediação deixa de se caracterizar como um processo de solução de conflitos centrado em técnicas de aproximação das partes, e passa a ser voltado para a matéria de fundo debatida. A diferença está em fazer determinadas afirmações, ressaltando que uma ou outra proposta deve ser aceita, ou indagar às partes sobre as possíveis consequiências de cada proposta. Esse tipo de mediação indica a necessidade de se nomear como mediador um profissional de reconhecida experiência na área debatida, para que as partes saibam a avaliação da questão para levá-la em consideração nas tratativas.
} 
Russomano esclarece que "a mediação consiste em se levar o conflito coletivo ao exame do mediador escolhido pelas partes. Nesse sentido, aproxima-se da conciliação. Mas, o mediador, ao contrário do conciliador, não desenvolve uma atividade apagada no processo de mediação: ele ouve, avalia, sugere e propõe ${ }^{\text {"198. }}$.

A conciliação não adentra nas questões subjetivas do conflito; quando utilizada judicialmente, é tratada como mera formalidade do processo. E mesmo quando tratada de maneira extra ou pré-processual, pelo fato de não trabalhar os conteúdos subjetivos dos conflitos, a conciliação soluciona apenas a parte aparente da questão, não permitindo que as partes trabalhem a relação intersubjetiva do conflito.

Finalmente, Antônio Rodrigues de Freitas Júnior adverte que na literatura sobre meios alternativos de tratamento de conflitos é comum a distinção conceitual de mediação e conciliação. A conciliação consiste na facilitação do diálogo e do entendimento de maneira objetiva e restrita aos aspectos externos do conflito, sem trabalhar a relação intersubjetiva que originou a situação conflitual, "podendo ser exitosa mesmo que dela não resultem efeitos modificadores das relações intersubjetivas em que o conflito se originara" ${ }^{199}$. Na mediação, o facilitador tenderá, por decorrência da ausência de poder decisório, a se ocupar da relação intersubjetiva em que o conflito se manifesta, em profundidade superior à presente no exercício da conciliação, e ela poderá ser efetuada com algum êxito, mesmo que dela não resulte um acordo das partes.

A mediação e a arbitragem são bem diferentes e a distinção essencial entre os dois institutos reside em quem toma a decisão que resolve a disputa. Enquanto na mediação as partes resolvem entre elas a solução, na arbitragem, a decisão é tomada por um árbitro, eleito de comum acordo. Assim, a arbitragem envolve uma decisão de um terceiro neutro ao litígio, enquanto na mediação a solução é tomada pelas próprias partes. A arbitragem ainda é um método adversarial, em que a decisão é imposta às partes por um árbitro.

\footnotetext{
${ }^{198}$ RUSSOMANO, Mozart Victor. Princípios gerais de direto sindical. 2. ed. Rio de Janeiro: Forense, 1995. p. 226.

${ }^{199}$ FREITAS JÚNIOR, Antonio Rodrigues. op. cit. p. 233 et seq., o autor esclarece ainda que a distinção não é unânime na literatura especializada em ADRs e acresce que "na literatura produzida no âmbito da teoria jurídica do processo, conciliação consiste na composição facilitada por terceiro a quem, por força de lei ou de contrato, assista o poder de decidir, julgando ou arbitrando o conflito".
} 
No conceito de Carlos Alberto Carmona ${ }^{200}$, a arbitragem é uma técnica para solução de controvérsias através da intervenção de uma ou mais pessoas que recebem seus poderes de uma convenção privada, decidindo com base nesta convenção, sem intervenção do Estado, sendo a decisão destinada a assumir eficácia de sentença judicial.

A decisão proferida pelo árbitro é imposta e de cumprimento obrigatório, em razão da adesão ao procedimento e obediência ao estabelecido na convenção de arbitragem. O árbitro normalmente determina o que está certo ou errado, enquanto o mediador, independentemente de qualquer juízo de valor, tenta levar as partes ao acordo ou à reconciliação.

Normalmente, a decisão do árbitro não permite contestação, tendo eficácia de sentença arbitral. Nesse sentido, Lília Maia de Moraes Sales ${ }^{201}$ esclarece que “o árbitro é juiz de fato e de direito e sua decisão arbitral não é sujeito à homologação ou passível de recurso no Poder Judiciário”. O árbitro deve ser um técnico ou especialista no assunto em discussão para dar um parecer e decidir a controvérsia, e o cumprimento de sua decisão é obrigatório.

Ainda, nas lições de Maurício Godinho Delgado ${ }^{202}$, o mediador não assume poderes decisórios perante as partes, as quais preservam toda a autonomia quanto à fixação da solução final para o litígio. Ele apenas contribui para o diálogo entre as partes, fornecendo-lhes subsídios, aparando divergências e instigando a resolução pacífica da controvérsia, não possuindo a prerrogativa de formular, isoladamente, a solução para o conflito.

Outro importante aspecto a ser observado é que tanto a conciliação como a arbitragem são aceitas e tipificadas no sistema jurídico nacional. Como exemplo, a primeira encontra-se claramente prevista nas Leis 9.099/95 (Juizados Especiais), Lei 9958/00 (Comissões de Conciliação Prévia), Lei 5869/73 (CPC), Consolidação das Leis do Trabalho etc, e a arbitragem possui lei específica (Lei 9.307/96).

\footnotetext{
${ }^{200}$ CARMONA, Carlos Alberto. A arbitragem no processo civil brasileiro. São Paulo: Malheiros Ed., 1993. p. 19.

${ }^{201}$ SALES, Lilia Maia de Morais. op. cit., p. 42.

${ }^{202}$ DELGADO, Maurício Godinho. op. cit., p. 668. Segundo o autor, o mediador “.. é figura, às vezes, chave na vida social, quer no âmbito das relações interindividuais ou microsociais, quer no âmbito comunitário mais amplo. É personagem, sem dúvida, importante no Direito Coletivo do Trabalho."
} 


\subsection{Judiciário e mediação: complementação em objetivos comuns (transformação social)}

A mediação corresponde não a um fenômeno da moda, mas a uma verdadeira necessidade de pensar e regular os litígios de maneira diferente da resposta judicial, que muitas vezes é insuficiente e inadaptada às necessidades das partes. A demora processual, o custo de um processo, o descompasso entre as decisões judiciais e a realidade das partes são alguns dos fatores que impedem a efetividade da Justiça.

O ensino jurídico, eminentemente técnico e formalista, que reconhece na lei a única expressão do Direito, torna os juízes distantes da sociedade e suas decisões meramente aplicações da lei ${ }^{203}$. Na mediação, além dos aspectos jurídicos do conflito, são colocados em evidência também os aspectos sociais e psicológicos do conflito, o que permite lidar com um objeto de trabalho maior que o processo judicial. Tal enfoque exige do mediador uma capacidade de atuação e análise que vai além da puramente jurídica. É necessária uma capacitação multidiscliplinar e especificamente voltada à teoria e prática da mediação.

A distância do Poder Judiciário em relação às partes ocorre principalmente com pessoas hipossuficientes, que não podem custear a demora da resolução, nem advogados capacitados para a necessária defesa. Tal fato é denunciado no artigo de Elio Gaspari, na Folha de São Paulo do dia 4 de fevereiro de 2007, que relata o estudo que dois advogados da Universidade de São Paulo fizeram no sentido de constatar que "quanto maior a desigualdade social numa região, maior é o conforto do poderoso, $^{, 204}$.

Em decorrência das mudanças e transformações que ocorrem continuamente na sociedade, o Poder Judiciário não pode ser considerado como o único local apropriado para a resolução dos conflitos que se apresentam. Corroboramos o entendimento de Daniele Ganância, no sentido de que "imaginar todas as vias para favorecer a mediação nos limites do judiciário constitui, para a justiça do amanhã, um desafio revelador de sua capacidade de adaptação à evolução de nossa sociedade” ${ }^{205}$.

\footnotetext{
${ }^{203}$ SALES, Lilia Maia de Morais. op. cit., p. 62.

${ }^{204}$ GASPARI, Elio. Folha de S. Paulo, São Paulo, 04 fev. 2007.

${ }^{205}$ GANÂNCIA, Danièle. Justiça e mediação familiar: uma parceria a serviço da co-parentalidade. Revista do Advogado, São Paulo, n. 62, p. 8, mar. 2001.
} 
A mediação permite aliviar o Judiciário, mas, sobretudo, tornar a resolução do conflito mais rápida, econômica e próxima dos cidadãos, permitindo resolver conflitos que, de alguma forma, sequer chegariam a ele. Ela pode ser considerada atividade jurídica em sentido amplo, principalmente se desenvolvida sob a supervisão do Poder Judiciário em serviços de mediação às varas judiciais específicas ${ }^{206}$.

Não podemos pretender que tal meio de resolução resolva os problemas do Judiciário, tampouco podemos criar uma outra espécie de justiça mais barata, de segunda categoria, destinada aos que não têm capacidades financeiras de recorrer ao sistema judicial. O que se pretende é oferecer novos mecanismos que possibilitem que as partes resolvam seus conflitos num ambiente onde o diálogo é estimulado e que funcione como fator de agregação social, preservando-se, assim, os relacionamentos entre as pessoas. A mediação possibilita a composição do conflito num ambiente mais colaborativo, podendo atuar de forma complementar ao processo na realização do escopo da pacificação social. A estrutura não-impositiva encontrada na mediação e o estímulo ao desenvolvimento da autodeterminação das partes constituem um diferencial que impulsiona todo o movimento mundial em prol da mediação.

\footnotetext{
${ }^{206}$ Nesse sentido a mediação tem sido empregada em alguns Tribunais, como ocorre no Projeto Íntegra Gênero e Família, que foi custeado pela iniciativa privada e, em parceria com a Instituição Pró-Mulher, Família e Cidadania, possibilitou a instalação de núcleos de mediação interdisciplinar em crimes processados pela Lei 9099/95, em conflitos de gênero e família.
} 


\section{CAPÍtUlO 4. MEDIAÇÃO NOS CONFLITOS COLETIVOS DE TRABALHO}

Pelo que se descreveu da mediação e pela abordagem diferenciada que ela emprega ao entendimento das circunstâncias subjacentes ao conflito, ela é especialmente recomendada aos casos em que envolvem relações interpessoais continuadas, como ocorre nas relações coletivas de trabalho.

A regular utilização da mediação na solução dos conflitos coletivos de trabalho permitirá uma nova forma de equilibrar as relações sociais, ampliando o acesso à justiça e aumentando a responsabilidade dos agentes sociais, especialmente dos sindicatos. Suas técnicas permitem que a solução seja conquistada pelas próprias partes, possibilitando um grau maior de satisfação e, conseqüentemente, uma maior efetividade na solução ajustada.

Os conflitos coletivos de trabalho envolvem uma relação continuada no tempo. A forma como são solucionados se reveste de vital importância para os atores envolvidos. Assim, deve ser buscada uma solução que promova a celeridade e a eficácia dos resultados; que reduza o desgaste emocional; que mitigue a reincidência do conflito; que atenue o custo financeiro; que facilite a comunicação, propiciando ambientes cooperativos.

Como observa Sala Franco ${ }^{207}$, nem todas as controvérsias laborais são suscetíveis de intervenção judicial e, nos casos em que a discussão jurídica carrega uma carga de conflitos de interesses encoberta, o Juiz não poderá solucionar o autêntico problema sem ferir as normas processuais. E nesse sentido, possivelmente por não encontrar outra maneira de solução, as partes exteriorizam numerosos conflitos de interesses como se fossem jurídicos, com o objetivo de obter uma solução judicial, que, nestes casos, será inadequada.

Muitas das manifestações decorrem de um conflito com dimensões objetivas e subjetivas, sendo certo que na maioria das vezes o não-reconhecimento da dimensão subjetiva representa um óbice à solução do conflito. Assim, é indispensável o instrumento técnico da mediação como complemento de pacificação dos conflitos coletivos

\footnotetext{
${ }^{207}$ SALA FRANCO, Tomas. Los procedimentos extrajudiciales de solucion de los conflictos laborales estabelecidos em la negociacion coletiva. Valencia: Tirant lo Blanch, 1996. p. 19.
} 
do trabalho. A mediação que apresentamos é diferente da mediação realizada pelo Ministério Público do Trabalho que, como veremos adiante, apresenta características específicas decorrentes do modelo jurisdicional trabalhista.

O campo de aplicação da mediação é vasto e o único empecilho é o direito indisponível, aquele sobre o qual o titular não pode dispor como bem lhe convier (ex. direito à vida, ao estado pessoal). O Direito do Trabalho é dotado de normas cogentes, de ordem pública e natureza tutelar, e o instituto ainda é visto com reservas no âmbito do direito individual.

Mas o princípio da irrenunciabilidade dos direitos trabalhistas não possui um caráter absoluto e o instituto da conciliação torna transigíveis quase todos os direitos. Observe-se que nem mesmo no âmbito judicial é permitida a transigência de todos os direitos, como a homologação de acordo isentando a empresa de cumprir as obrigações alusivas à segurança e medicina do trabalho, a assinatura de carteira e as questões relativas aos direitos sindicais.

Não pretendemos esgotar o assunto relacionado ao princípio de irrenunciabilidade aplicado no direito do trabalho. Mas é importante destacar a existência de três espécies de normas no Direito do Trabalho, quais sejam: 1. Normas de conteúdo imperativo e de alcance geral: são aquelas de interesse mais social do que individual, cuja infração poderá ou não acarretar ao infrator punição pecuniária. Elas formam uma relação entre o infrator e a Administração Pública. Como exemplo, teríamos as multas pela nãoassinatura da Carteira de Trabalho; 2. Normas de natureza imperativa: são aquelas que compõem o conteúdo dos contratos de trabalho. Sua infração tem por conseqüência a punição administrativa e indenização (ou simples reparação ao trabalhador lesado); 3. Normas dispositivas ou supletivas: são aquelas que podem ser derrogadas pelo contrato.

Apenas as primeiras são irrenunciáveis e intransigíveis. Não podem ser objeto de acordo entre empregado e patrão, nem quando a questão já está sub judice. As demais podem ser transigidas pelas partes, a exemplo do que ocorre nas Comissões de Conciliação do Trabalho e nas próprias audiências trabalhistas.

No campo do direito coletivo, a mediação deve ser estimulada e não pode ser vista com reservas, pois o parágrafo $2^{\circ}$ do artigo 114 da Constituição Federal determina a necessidade de tentativa de negociação coletiva antes da propositura do dissídio coletivo. Os direitos coletivos se mostram renunciáveis quando a negociação é 
realizada por meio do Sindicato de Classe. E nesse sentido, o artigo $7^{\circ}$, inciso XXXV, da Constituição Federal, reconhece os acordos e convenções coletivas de trabalho. Ainda, como já ressaltado no presente trabalho, a negociação é amplamente estimulada no âmbito das relações coletivas de trabalho e a mediação apresenta-se como instrumento facilitador e promotor da negociação coletiva. Configura-se, assim, como o meio mais indicado de atuação para incentivar a aproximação das partes envolvidas ${ }^{208}$.

\subsection{Histórico de Institucionalização da Mediação no Brasil}

O desenvolvimento da mediação ainda é incipiente no Brasil, mas já existe grande preocupação em relação à institucionalização de tal forma de resolução de disputas no contexto jurídico nacional. Além disso, existem diversas propostas legislativas em andamento ${ }^{209}$ que buscam regular seu procedimento, o que denota a importância do tema e a necessidade na regularização da matéria. Destacaremos algumas delas:

- Projeto de Lei n ${ }^{\circ} 4.827 / 98$, substitutivo ao Projeto de Lei da Câmara ${ }^{\circ}$ 94/2002 que "institucionaliza e disciplina a mediação, como método de prevenção e solução consensual de conflitos". Elaborado pela Deputada Federal Zulaiê Cobra, o projeto iniciou sua longa trajetória legislativa junto ao Congresso Nacional no ano de 1998. Inicialmente continha apenas sete artigos, mas sofreu alterações diversas ao longo de sua jornada.

No dia 21 de junho de 2006, a Comissão de Constituição, Justiça e Cidadania (CCJ) do Senado aprovou o PL 94/2002 e, posteriormente, o Plenário do Senado Federal confirmou a aprovação do texto. Em novembro de 2006, o Deputado José Eduardo Cardozo apresentou parecer pela aprovação do Substitutivo do Senado ${ }^{210}$ e desde março de 2007 encontra-se parado na Câmara dos Deputados, em razão das alterações sofridas.

\footnotetext{
${ }^{208}$ AMARAL, Lídia Miranda de Lima. Mediação e arbitragem: uma solução para os conflitos trabalhistas no Brasil. São Paulo: LTr, 1994. p. 24. Segundo a autora, “o mediador intervém quando os recursos das partes em termos de conhecimento, persuasão e, em alguns casos, violência econômica (greve ou lockout), não conseguiram que se chegasse a uma solução. Cabe-lhe, então, apresentar algo de novo ou diferente às muitas possibilidades levadas em conta pelas próprias partes, podendo estimular ou mesmo ajudar os próprios interessados para que façam ofertas e propostas com base para chegarem a um acordo. Fica ele diante da necessidade de sugerir soluções para situações consideradas, às vezes, impossíveis."

${ }^{209}$ Os projetos de lei seguem anexos ao presente trabalho.

${ }^{210}$ Interessante observar que em seu voto pela aprovação do Substitutivo do Senado, o Deputado lança críticas ao próprio conceito de mediação: "apesar de entendermos que o conceito de mediação é muito mais abrangente do que aquele delimitado no presente projeto, conforme oportunamente lembrado pelo Instituto
} 
O referido Projeto pretende criar a mediação paraprocessual, obrigatória para quem pretende demandar em juízo, tornando requisito obrigatório ao desenvolvimento regular de todo processo de conhecimento de natureza civil. Para cumprimento desse requisito obrigatório, poderá se optar por uma mediação prévia, que é anterior à propositura da ação ou incidental, que ocorre no curso do processo, devendo o juiz suspender o feito para tal fim. Ambas podem ser judiciais, quando se utilizarem de mediadores advogados, com três anos de experiência, aprovados para essa finalidade e integrantes do "Registro de Mediadores" dos Tribunais de Justiça ou extrajudiciais, quando fizerem uso de instituições de mediação ou mediadores independentes. Ele não exclui a possibilidade de mediação nos conflitos trabalhistas, mas seria importante inserir tal possibilidade no seu artigo $1^{\circ}$.

- Projeto de Lei $n^{\circ}$ 1345/2003, que institui instância conciliatória nos Tribunais;

- Projeto de Lei $n^{\circ}$ 4948/05, que altera o artigo 1571 do Código Civil para inserir a recomendação na regulação dos efeitos da separação e divórcio;

- Projeto de Lei ${ }^{\circ}$ 4891/2005, que regula o exercício das profissões de Árbitro e Mediador;

- Anteprojeto de Lei sobre Mediação encampado pela OAB do Brasil ${ }^{211}$;

- Projeto de Lei Estadual no 632/2007, que disciplina a criação dos Setores de Conciliação para as Varas Cíveis e de Família, em fase processual ou extraprocessual.

Ainda, o instituto da mediação tem sido desenvolvido por meio de programas de acesso à justiça e de justiça comunitária e implementados por Tribunais e ONGs. Alguns deles serão abaixo destacados:

- Instituto Pró-Mulher, Família e Cidadania é uma Instituição sem fins lucrativos, fundada em 11/11/1977, que presta atendimento gratuito em Mediação, nas áreas jurídica, psicológica e social à população de baixa renda. Suas principais atuações estão voltadas para a área de violência doméstica, de gênero e urbana. Pratica intervenção direta à população em sua sede, na sede da PAJ-Procuradoria de Assistência Judiciária do

Brasileiro de Direito de Família, representado pelas Doutoras Giselle Groeninga e Águida Barbosa, o que deverá ser levado em conta nas regulamentações futuras sobre essa matéria, parece-nos que o substitutivo apresentado pelo Senado melhorou substancialmente o projeto inicial aprovado pela Câmara."

${ }^{211}$ Texto publicado no Boletim da Associação dos Advogados de São Paulo, São Paulo, n. 2.180, 9 a 15 out. 2000. p. 3-7. 
Estado de São Paulo e no COJE-Centro de Orientação Jurídica e encaminhamento à Mulher da Procuradoria Geral do Estado. Recebe casos decorrentes de processos-crime de gênero e família processados pela Lei 9.099/95 do JECRIFAM - Juizado Especial Criminal da Família Central, para mediação em sua sede ${ }^{212}$;

- Projeto Íntegra Gênero e Família, que foi custeado pela iniciativa privada e, em parceria com a Instituição Pró-Mulher, Família e Cidadania, possibilitou a instalação de núcleos de mediação interdisciplinar em crimes processados pela Lei 9099/95, em conflitos de gênero e família;

- Projeto "Porto Alegre" - implementado em outubro de 1993, para aconselhamento familiar junto ao Fórum Central de Porto Alegre. Previa a atuação de um Juiz de Direito aposentado, advogados e profissionais da área de assistência social ${ }^{213}$;

- NAF - Núcleo de Atendimento Familiar do Judiciário - instalado no Fórum Central de Porto Alegre em 1997, tem como objetivo contribuir para o encerramento rápido e adequado dos processos das Varas de Família e Sucessão, Infância e Juventude, bem como os casos remetidos pelo Projeto Conciliação;

- Programa de Estímulo à Mediação do Tribunal de Justiça do Distrito Federal - a Resolução n. 02 de 22 de março de 2002, instituiu o Serviço de Mediação Forense, representando uma ação específica do Tribunal de Justiça do DF para a implantação e utilização de métodos alternativos de resolução de disputa no processo judicial, aplicando técnicas de negociação da Universidade de Harvard, aliadas às técnicas empíricas da conciliação e algumas teorias da mediação ${ }^{214}$;

- Projeto de Mediação da Vara da Infância e Juventude de Guarulhos, que teve como finalidade realizar e estudar os resultados de Mediação em casos de conflitos familiares e atos infracionais de menor gravidade ${ }^{215}$.

Destaque-se, ainda, a importância do núcleo de estudos e debates do CEBEPEJ - Centro Brasileiro de Estudos e Pesquisas Judiciais ${ }^{216}$, que atualmente estuda

\footnotetext{
${ }^{212}$ FREITAS JÚNIOR, Antonio Rodrigues. op. cit. p. 271.

${ }^{213}$ TARGA, Maria Inês Correia de Cerqueira César. op. cit., p. 191.

${ }^{214}$ Interessante conhecer a página na internet sobre o PROGRAMA de Estímulo à Mediação. Tribunal de Justiça do Distrito Federal. Disponível em: <http://www.tjdft.gov.br/tribunal/institucional/prog_estimulo_mediacao/guia/guia.pdf>.

${ }^{215}$ ISSLER, Daniel. O Projeto de Mediação da Vara da Infância e Juventude de Guarulhos-SP (Parceria Unimesp/FIG). In: GRINOVER, Ada Pelegrini; WATANABE, Kazuo, LAGRASTA NETO, Caetano. op. cit., p. 84-86.

${ }^{216}$ O CEBEPEJ é uma associação civil, não-governamental, fundada em abril de 1999 e sem fins lucrativos que tem como objetivo desenvolver estudos e pesquisas sobre a Justiça brasileira. Interessante consultar informações sobre sua criação, suas finalidades institucionais, objetivos e conteúdo disponibilizado no site
} 
novos modelos de gerenciamento de processos judiciais, sendo que a utilização de meios alternativos de resolução faz parte de uma das perspectivas de tais estudos. Desde 2004, referido órgão trabalha juntamente com o Tribunal de Justiça do Estado de São Paulo em iniciativas voltadas à utilização de meios consensuais de solução de conflitos junto ao Poder Judiciário $^{217}$. E nesse sentido foram realizadas experiências-piloto nas comarcas de Patrocínio Paulista e Serra Negra, onde foram instaladas duas unidades de mediação, uma voltada às ações envolvendo direito de família, questões relacionadas à área da infância e juventude e outra destinada aos casos cíveis em geral. Em ambas é possível o agendamento de sessões destinadas à mediação tanto na fase pré-processual quanto na fase processual. Tal experiência teve a aprovação do Tribunal de Justiça do Estado de São Paulo e foi regulamentada pelo Provimento 894/2004 e, posteriormente, substituída e aperfeiçoada pelo Provimento 953/2005 218 .

Dada a importância do tema e a necessidade de uma maior comunicação e contato entre as diversas entidades que cuidam da mediação, em setembro de 2007 foi instituído o Fórum Nacional de Mediação - FONAME, integrado, voluntariamente, por entidades de qualquer natureza ou núcleos regularmente constituídos, que se dedicam ao aperfeiçoamento, à divulgação e à prática da mediação de $\operatorname{conflitos}^{219}$. O FONAME é composto atualmente por dois coordenadores (Célia Regina Zapparolli e Adolfo Braga Netto) e Comitê Executivo composto por cinco membros (Kazuo Watanabe, Caetano Lagrasta Neto, Rosane Mantilla, Mônica Galano e Antonio Rodrigues de Freitas Júnior).

\footnotetext{
CENTRO BRASILEIRO DE ESTUDOS E PESQUISAS JUDICIAIS. Disponível em: $<$ Www.cebepej.org.br.>.

${ }^{217}$ GRINOVER, Ada Pelegrini; WATANABE, Kazuo, LAGRASTA NETO, Caetano. op. cit. Importante esclarecer que a obra citada é fruto de estudos e colaboração de vários membros do Núcleo de Estudos e Debates do CEBEPEJ.

${ }^{218}$ Conforme anexos ao presente trabalho.

${ }^{219} \mathrm{O}$ Regulamento do FONAME (anexo ao presente trabalho) não realizará apresenta as atividades de mediação, formação, nem capacitação de mediadores e apresenta os seguintes objetivos:

"Art. $2^{\circ}$. O FONAME tem por objetivo:

I - difundir a cultura da paz;

II- - promover a contínua troca de idéias e o intercâmbio de experiências entre profissionais e estudiosos da mediação e de outros meios de solução pacífica de conflitos;

III- formular e definir critérios ou indicadores destinados a constituir parâmetros, mínimos e/ou ótimos a serem observados:

a) na capacitação, na formação e na sensibilização para meios de solução pacífica de conflitos;

b) na qualificação de profissionais em meios de solução pacífica de conflitos;

c) na orientação quanto a preceitos e procedimentos éticos, a serem observados por profissionais, voluntários, servidores e estudiosos devotados à promoção de meios de solução pacífica de conflitos.

IV - - promover eventos que se ocupem dos meios de solução pacífica de conflitos.

IV - opinar sobre proposituras legislativas e contribuir para a produção normativa sobre meios de solução pacífica de conflitos".
} 


\subsection{Institucionalização da Mediação no Direito Coletivo de Trabalho}

Em relação aos conflitos coletivos, são inúmeras as disciplinas jurídicas que possibilitam a realização da mediação. Como já salientado, o artigo 114 , parágrafo $1^{\circ}$, da Constituição Federal, incentiva a negociação coletiva e a mediação é um dos instrumentos apropriados para tal função. A Instrução Normativa $n^{\circ}$ 04/93, do Tribunal Superior do Trabalho, reafirma a necessidade de esgotamento da tentativa prévia de autocomposição antes do ajuizamento do dissídio coletivo.

A mediação coletiva realizada pelo Ministério do Trabalho é praticada há muito tempo. Atualmente, ela está regulamentada pelo Decreto $\mathrm{n}^{\circ} 1.572$, de 28 de julho de 1995 e pela Portaria $n^{\circ}$ 817, de 30 de agosto de 1995, do Ministério do Trabalho, que estabelece critérios para a participação do mediador nos conflitos de negociação coletiva. A Portaria $\mathrm{n}^{\circ}$ 818, de 30 de agosto de 1995, também do Ministério do Trabalho, estabelece critérios para o credenciamento do mediador perante as Delegacias Regionais do Trabalho.

A Lei 10.192 , de $14.02 .2001^{220}$ estabeleceu providências complementares ao Plano Real e determinou expressamente a solução de questões referentes a salário e condições de trabalho por meio da negociação coletiva, promovida diretamente pelas partes ou as partes podem, de comum acordo, escolher mediador privado ou solicitar a indicação de mediador público do Ministério do Trabalho.

Fruto de uma medida provisória, cuja primeira edição data de 1994, a lei 10.101, de 19 de dezembro de 2000, que disciplina a participação dos trabalhadores nos lucros ou resultados da empresa, optou pelo incentivo à negociação coletiva, facultando às partes, em caso de tentativa frustrada de negociação, a utilização da mediação ou da arbitragem. Seu objetivo é melhorar as atividades das empresas e, com isso, a própria remuneração de seus empregados, auxiliado por um sistema inovador de resolução de disputas. Ela dispõe sobre a participação dos trabalhadores nos lucros e resultados das empresas, prevendo, em seu artigo $4^{\circ}$, que neste tipo de negociação entre empregado e empregador, caso ocorra impasse, se estabeleça a possibilidade de utilização da mediação, coordenada por mediador independente, pertencente ao quadro oficial do Ministério do

\footnotetext{
${ }^{220} \mathrm{O}$ artigo 11 estabelece o seguinte: “Art. 11 Frustrada a negociação entre as partes, promovida diretamente ou através de mediador, poderá ser ajuizada a ação de dissídio coletivo”.
} 
Trabalho ou ainda mediador vinculado a alguma instituição privada, escolhido de comum acordo entre as partes.

Em decorrência da implementação das medidas econômicas trazidas pelo Plano Real, a Lei $\mathrm{n}^{\circ} 10.192$, de 14 de fevereiro de 2001, determina o reajuste anual dos salários com base na variação do IPC-r acumulado dos últimos doze meses até a database anterior, porém exigindo que sejam entabuladas negociações para o regramento das relações capital-trabalho da categoria. Estabelece a possibilidade de, uma vez frustrada a negociação, as partes utilizarem mediador, inclusive do Ministério do Trabalho, para estimular uma solução negocial no prazo máximo de 30 dias. Não havendo consenso, prevê a lavratura de ata com as causas motivadoras do conflito e as reivindicações econômicas, documento este que instruirá a representação para que ambas as partes possam instaurar o dissídio coletivo.

As alterações legislativas anteriormente referidas buscaram implementar um papel mais ativo na solução de controvérsias trabalhistas para o Ministério do Trabalho e Ministério Público do Trabalho, que vêm exercendo um papel importante na administração dos conflitos no âmbito das relações coletivas de trabalho, embora se encontram limitados à rigidez prevista na legislação e a restrição a eventuais parcelamentos de débitos trabalhistas.

Ainda, a Convenção 154 da OIT, ratificada pelo Brasil em 10/7/93 e aprovada pelo Decreto Legislativo $\mathrm{n}^{\circ}$ 22, de 12/5/92 também traça os parâmetros para a promoção e o incentivo da negociação coletiva para resolução dos conflitos de trabalho. $\mathrm{O}$ artigo $5^{\circ}$ da referida Convenção dispõe que "deverão ser adotadas medidas adequadas às condições nacionais no estímulo à negociação coletiva", sendo que o parágrafo $2^{\circ}$ de tal artigo menciona a necessidade de mecanismos que "tomem parte voluntariamente as partes na negociação coletiva". $\mathrm{O}$ artigo $8^{\circ}$ ressalta que essas medidas "não deverão ser concebidas ou aplicadas de modo a restringir a liberdade de negociação coletiva” ${ }^{221}$. A Recomendação 163 da OIT declara que o direito de negociação deve ser amplo, assegurado a todas as organizações e assinala a conveniência da disponibilidade de informações facilitadas entre as partes para que ambas possam negociar conhecendo a situação da outra, e também pelo Estado que dispõe de dados econômicos e sociais globais do país. O mesmo documento sugere que conste das convenções coletivas a previsão de mecanismos que

${ }^{221}$ ORGANIZAÇÃO INTERNACIONAL DO TRABALHO - OIT. A liberdade sindical. Trad. Edílson Alkmin Cunha. São Paulo: LTr, 1993. p. 95. 
serão adotados pelas partes para a solução das controvérsias que resultarem da sua aplicação, como a mediação e a arbitragem $\operatorname{privada}^{222}$.

Passaremos a analisar a figura do mediador, suas funções, objetivos e condutas de acordo com um Código de Ética, estabelecendo um paralelo entre o procedimento da mediação até então descrito e as atividades de mediação realizadas pelo Ministério do Trabalho e Emprego.

\subsection{Mediador - Funções, Papéis e Código de Ética e Mediação pelo Ministério do Trabalho e Ministério Público do Trabalho}

O conhecimento da teoria e das técnicas da Mediação é de suma importância para a compreensão das mudanças e transformação dos conflitos. Amplia a eficácia do instituto da mediação, priorizando a manutenção das relações.

Partindo do ponto de vista de cada uma das partes, o mediador deve fazer uma primeira avaliação, identificando os fatos, as peculiaridades, as posições e os interesses das partes. Num segundo momento, ele avalia a atitude das partes, com vistas a melhorar a comunicação, encoraja as opções, cria novas idéias, testa a validade das soluções propostas, buscando diminuir a diferença entre elas. Para isso, o mediador deve ser uma pessoa neutra e despida de qualquer poder decisório. Ele tem que ser capaz de observar a disputa, sem perder a capacidade de reflexão e sem tomar qualquer partido ou apresentar prognósticos sobre a questão debatida.

O mediador é, assim, peça fundamental para a mediação, capaz de coordenar os conflitos entre as partes com técnicas apropriadas e aplicação de ciências de origens diversas. Sua principal função é auxiliar as partes, para que estas tomem suas decisões de maneira consciente, livre e responsável. O protagonismo das partes deve ser sempre estimulado, legitimando-se a participação de todos os presentes à sessão de mediação.

O mediador deve compreender os diferentes valores e percepções das partes envolvidas no conflito, sem avaliar a questão com base em seus próprios préconceitos e paradigmas. Necessário, assim, para que a abordagem dos conflitos seja feita

\footnotetext{
${ }^{222}$ NASCIMENTO, Amauri Mascaro. O debate sobre negociação coletiva. LTr: revista legislação do trabalho,
} São Paulo, v. 64, n. 9, p. 1115, set. 2000. 
de maneira completa, aprender a ouvir e respeitar o conjunto de todos os elementos que formam as concepções das partes, como exemplo, seus valores morais, sociais, econômicos e profissionais, sem tomar qualquer juízo de valor. Deverá valer-se da independência, no sentido de ter capacidade de agir livre de toda e qualquer influência.

Se a questão debatida envolver aspectos que dependam de conhecimentos técnicos específicos, o mediador poderá interromper os trabalhos de mediação para que as partes busquem as informações necessárias à continuidade das discussões ou requerer um co-mediador para realizar a atuação conjunta com outro profissional especializado na área do conhecimento subjacente ao litígio ${ }^{223}$.

Todas as funções do mediador devem ser exercidas de forma imparcial, garantindo-se aos mediados o tratamento com igualdade e isenção de ânimos, o que garante a confiança das partes, fundamental para um bom resultado na negociação. Como ressaltado anteriormente, o mediador deverá ter capacidade para mediar a controvérsia, além de ser diligente, cuidadoso e capaz de compreender a dinâmica do conflito. Ele deverá possibilitar o diálogo construtivo entre as partes, sem impor qualquer solução. Sua idoneidade é condição necessária à credibilidade do procedimento, não devendo existir qualquer predileção por uma das partes, nem posicionamento prévio sobre as questões debatidas.

Deverá, ainda, ser diligente, no sentido de dedicar-se ao caso concreto, de assumir compromissos compatíveis com sua capacitação e de acordo com os princípios da mediação já narrados anteriormente. É seu dever, ainda, garantir o sigilo de tudo o que foi discutido nas sessões de mediação, garantindo-se, assim, o princípio da confidencialidade.

O mediador deve observar alguns parâmetros mínimos de conduta, fundamentais à atuação nos referidos procedimentos voluntários. Jean-François Six $^{224}$ enumera os seguintes deveres éticos do mediador: coragem, prudência e justeza. Coragem no sentido de resistir às pressões de resolução rápida do conflito, de evitar o imediatismo, de agir em nome da paz, não em nome de um poder. A prudência diz respeito à cautela que

\footnotetext{
${ }^{223}$ Nesse sentido, dispõe o Projeto de Lei no $94 / 02$, art. 16, na forma do Substitutivo aprovado pela Comissão de Constituição, Justiça e Cidadania do Senado Federal. Enquanto o caput e o $\S 2^{\circ}$ contempla a autonomia da vontade das partes ou do mediador no tocante à participação ou não de co-mediador, o $\S 1^{\circ}$ estabelece $\mathrm{a}$ obrigatoriedade da co-mediação e exige a presença de psiquiatra, psicólogo ou assistente social nas ações que versem sobre o estado da pessoa e Direito da Família.

${ }^{224}$ SIX, Jean-François. Dinâmica da mediação. Tradução de Águida Arruda Barbosa, Eliana Riberti Nazareth, Giselle Groeninga. Belo Horizonte: Del Rey, 2001. p. 242-252.
} 
o mediador deve ter de estar sempre à escuta, não se inclinando aos sentimentalismos nem às expectativas; seria o bom senso do mediador, sempre de acordo com a boa vontade $\mathrm{e}$ inteligência. Justeza no sentido de permitir que as partes alcancem o melhor caminho.

Cada instituição de mediação possui o seu Código de Ética. A análise das diferentes determinações éticas em diversos países ${ }^{225}$ e instituições, leva-nos à conclusão de que a maioria dos princípios é equivalente. No Brasil, o Código de Ética do Conselho Nacional das Instituições de Mediação e Arbitragem - CONIMA ${ }^{226}$, estabelece os seguintes princípios a serem adotados pelo mediador:

- Independência: diz respeito às condições objetivas do mediador e não ao aspecto subjetivo. $\mathrm{O}$ mediador deve ser pessoa sem vínculo com as partes; não pode ser parente, amigo, empregador;

- Imparcialidade: nos termos narrados no item anterior;

- Credibilidade: o mediador deve ser idôneo e merecer a confiança das partes. Como já ressaltado, deverá agir com boa-fé observando sempre os valores de honestidade e altruísmo;

- Aptidão: diz respeito à capacidade técnica do mediador em atuar no conflito para o qual foi escolhido. Rosane Mantilla de Souza ${ }^{227}$ esclarece que a mediação exige uma sabedoria e práticas multidisciplinares e as teorias que remetem à sua organização são provenientes de diversos domínios científico-técnicos, como a teoria da comunicação, dos conflitos, da negociação, dos jogos. Com maior ou menor domínio, ou nem sequer conhecimento dessas teorias, o mediador é treinado no uso de um método. Necessária a formação ou capacitação de mediadores e atualmente existem diversos cursos com tal finalidade, daí a importância do citado FONAME, que tem como um dos seus objetivos a formulação e definição de critérios ou indicadores destinados a constituir parâmetros, mínimos e/ou ótimos a serem observados na capacitação e na formação de mediadores;

${ }^{225}$ Códigos de Ética de Mediadores da França e Canadá encontra-se anexado no presente trabalho.

${ }^{226} \mathrm{O}$ Conima é uma entidade sem fins lucrativos, fundada em 24 de novembro de 1997, que tem como objetivo principal congregar e representar as entidades de mediação e arbitragem. Para conferir seus objetivos e conhecimento de seus trabalhos e Código de Ética dirigido ao mediador, consultar o site CONIMA - Conselho Nacional das Instituições de Mediação e Arbitragem. Disponível em: $<$ Www.conima.org.br>.

${ }^{227}$ SOUZA, Rosane Mantilla de. Mediação social: uma experiência de trabalho em comunidade de baixa renda. In: MUSZKAT, Malvina Ester (Org.). Mediação de conflitos: pacificando e prevenindo a violência. São Paulo: Summus, 2003. p. 90. 
- Confidencialidade: diz respeito à obrigação de guardar sigilo a respeito de tudo o que foi revelado na mediação. A observação de tal princípio propicia a criação de maior credibilidade e liberdade para as partes debateram suas posições e divergências. É fundamental para a exploração dos melhores caminhos possíveis para a solução de seus litígios. Tais informações devem ser resguardadas, mesmo diante de um futuro processo judicial e o que foi dito numa sessão de mediação não pode ter natureza probatória;

- Diligência: o mediador deve realizar suas tarefas com o máximo de dedicação, atendendo as partes da forma mais completa possível, respeitando seus interesses e decisões e conduzindo as sessões num prazo razoável e de acordo com os interesses das partes e desenvolvimento das discussões, sem qualquer tipo de pressão para a celebração de um acordo.

Referidas normas de conduta estão diretamente ligadas ao próprio conceito de mediação apresentado no presente trabalho e expressam apenas um padrão mínimo de conduta a ser respeitado e observado pelos mediadores.

Observamos que, embora o Decreto $\mathrm{n}^{\circ} 1.572 / 95$ estipule em seu artigo $2^{\circ}, \S 3^{\circ}$, letra $a$, a designação de mediador privado, desde que credenciado junto ao Ministério do Trabalho ${ }^{228}$, para atuar na composição do conflito, na prática a utilização ocorre apenas por meio dos mediares públicos, que são os fiscais do trabalho. Ocorre que quando a mediação é realizada dessa maneira, as partes, principalmente a empresa, não se sentem muito à vontade para expor todos os seus problemas, sob o risco de incidir, futuramente, uma ação fiscalizadora diante do conhecimento das causas geradoras do conflito. Como ressalta Aparício Querino Salomão ${ }^{229}$, ocorre uma coerção indireta, o que descaracteriza o procedimento de mediação ora proposto.

Citado autor acrescenta, ainda, que a mediação do Ministério do Trabalho normalmente ocorre por iniciativa de uma das partes, que convida a outra a comparecer à reunião (mesa redonda), e, diante da ausência da parte suscitada é lavrado um termo que surtirá os seguintes efeitos: 1. se for negociação coletiva de data-base, o termo de ausência servirá como documento comprobatório de tentativa de negociação e habilitará o sindicato a ajuizar o dissídio coletivo; 2. se for o descumprimento da norma coletiva, a ausência da empresa suscitada poderá dar ensejo a procedimento fiscalizatório,

\footnotetext{
${ }^{228}$ A Portaria 818 do Ministério do Trabalho, de 30 de agosto de 1995, estabelece critérios para o credenciamento do mediador perante as DRTs.

${ }^{229}$ SALOMÃO, Aparício Quirino. A mediação de conflitos coletivos no Ministério do Trabalho. LTr: legislação do trabalho. Suplemento trabalhista, São Paulo, n. 113, p. 521-523, 1998.
} 
além do ajuizamento, por parte do sindicato suscitante, da competente ação de cumprimento.

A mediação praticada no Ministério do Trabalho possui peculiaridades próprias do ambiente em que se desenvolve, que não parece ser o mais imparcial, exatamente pela função fiscalizadora de referido órgão, que possui, como atividade precípua, a fiscalização e o zelo pela correta observância das normas trabalhistas. Assim, inexiste plena efetividade do serviço de mediação prestada pelo Ministério do Trabalho, vez que as questões intersubjetivas dos conflitos não são tratadas de maneira a levar uma reconstrução do relacionamento. Além disso, pelo próprio risco da exposição num ambiente fiscalizatório, as partes deixam de expor com sinceridade todos os fatos e circunstâncias discutidos no conflito, desfavorecendo o efetivo diálogo cooperativo.

Não obstante a disposição prevista no artigo $2^{\circ}$ do Decreto 1.572 , de 28.07.1995, que prevê que as partes poderão escolher um mediador de comum acordo para a solução do conflito, observamos que tal prática não é desenvolvida adequadamente, uma vez que a mediação realizada em alguns casos pelo Ministério do Trabalho é insuficiente para a solução do conflito. Trata-se, na verdade, de mais uma ficção jurídica do que um instituto realmente existente na prática. Sua estrutura não permite, por exemplo, que as partes sejam realmente esclarecidas sobre a situação econômica da empresa, sobre o mercado de trabalho. Nessas condições, as alternativas e as bases para uma boa negociação são extremamente limitadas.

Como exemplo, o Ministério do Trabalho e Emprego implantou, por meio da Portaria $\mathrm{n}^{\mathrm{o}}$ 282, de 6 de agosto de 2007, o Sistema de Negociações Coletivas de Trabalho - Mediador, que cria inúmeras regras para fins de elaboração, transmissão, registro e arquivo, via eletrônica, dos instrumentos coletivos de trabalho e a Instrução Normativa $\mathrm{n}^{\circ} 6$, editada no mesmo dia, procura informatizar o registro de acordos e convenções coletivas previsto no art. 614 da CLT. O próprio nome do sistema criado Mediador - já contraria o conceito de mediador até então adotado ${ }^{230}$. Não bastasse, o excessivo sistema burocrático ofende a ampla liberdade de negociação e a própria autonomia sindical.

Como se pode observar, o artigo $9^{\circ}$ de referida Instrução Normativa disciplina que as convenções e os acordos coletivos serão analisados em sua forma e

\footnotetext{
${ }^{230}$ Mediador é o terceiro, escolhido ou aceito pelas partes, que procura aproximá-las na busca de uma solução amistosa.
} 
conteúdo $^{231}$, permitindo que o analista ministerial vete o conteúdo do instrumento ${ }^{232}$ e invalide o que entende ser formalmente irregular ou nulo no seu conteúdo. E para piorar, o parágrafo $4^{\circ}$ do referido artigo $^{233}$ contraria o disposto no artigo $614, \S 1^{\circ}$ da CLT, que disciplina que as convenções ou os acordos coletivos entram em vigor três dias após a data da entrega nos órgãos regionais do Ministério do Trabalho. Ainda, a recente Instrução Normativa atrita-se com o entendimento do Tribunal Superior do Trabalho, que, por meio da Resolução n 116, de 20 de março de 2003, cancelou sua Instrução Normativa $n^{\circ}$ 4, de 14 de junho de 1993, que inviabilizava o dissídio coletivo mediante exigências de natureza formal.

E, no tocante ao conteúdo das convenções e acordos coletivos, o disposto no artigo 614 da CLT leva-nos ao entendimento de que o Ministério do Trabalho não tem competência para interferir, nem para julgar as cláusulas estipuladas pelas partes. Não obstante, como se extrai do atual Manual do Mediador, além das condições acima narradas, as partes não poderão sequer determinar a ordem das cláusulas ajustadas, vez que terão que se adaptar conforme os grupos ou sub-grupos determinados pelos técnicos do Ministério do Trabalho, sendo que o sistema fará automaticamente a numeração de tais cláusulas. Evidente, assim, que a mediação realizada no Ministério do Trabalho não é harmônica aos procedimentos próprios de mediação preconizados no presente trabalho.

Não podemos deixar de mencionar que o Ministério Público também pode, por definição legal, atuar como mediador de conflito. O Termo de Ajuste de Conduta previsto no artigo $5^{\circ}$ da Lei 7.347/85 (Lei da Ação Civil Pública) e a Lei n ${ }^{\text {9.958/2000, }}$ que alterou o artigo 876 da CLT, consolidam a possibilidade de utilização do mecanismo extrajudicial de solução de interesses coletivos e difusos. Mas, como acenado anteriormente e sem pretender desconsiderar o prestígio e a boa intenção dos Procuradores do Trabalho, observa-se que, da mesma forma que ocorre nas Delegacias Regionais do Trabalho, o ambiente em que se desenvolve a mediação não parece ser o mais imparcial, vez que, pela própria competência de atuação do Ministério Público, determinada pelo artigo 127 da Constituição Federal, restrita à defesa da ordem jurídica e dos direitos sociais

\footnotetext{
${ }^{231}$ Art. 9o: "Após o protocolo do requerimento de registro do instrumento transmitido via internet ao Ministério do Trabalho e do Emprego por meio do sistema Mediador, o serviço competente deverá cadastrar o seu depósito no módulo desse Sistema e informar a data do protocolo e o número do processo e iniciar a sua análise formal".

${ }^{232}$ Art. $9^{\circ}, \S 3^{\circ}$ : “Em caso de nulidade, o servidor deverá promover o arquivamento sem registro do instrumento coletivo, justificando seu ato, e informar aos interessados por meio de ofício".

${ }^{233}$ Art. $9^{\circ}$, $\$ 4^{\circ}$ : "Expirada a vigência do instrumento coletivo sem que tenham sido efetuadas as retificações necessárias, o processo será arquivado sem registro”.
} 
e individuais indisponíveis, percebe-se que muitas questões intersubjetivas dos conflitos podem não ser demonstradas claramente, dificultando-se o efetivo diálogo cooperativo. Além disso, as partes não podem livremente, escolher o mediador que participará das sessões.

\subsection{Experiências no Direito Estrangeiro}

A mediação tem apresentado alto índice de ascensão e aceitação em vários países. É praticada há vários anos nos Estados Unidos e Canadá, também muito utilizada na França e na Argentina. A mediação possui particularidades nesses países, que serão a seguir desenvolvidas.

Apesar de o nosso sistema jurídico se filiar à tradição romanogermânica, com sua formulação realizada em Leis e Códigos, tem recebido fortes influências da tradição anglo-saxônica, onde o Direito é formulado por meio da jurisprudência (common law). Exemplo disso é a edição de Súmulas que direcionam o julgamento de muitos juízes de instâncias inferiores.

\subsubsection{Argentina}

No direito positivo argentino, o embrião da mediação foi a edição da Resolução n ${ }^{\circ}$ 297/91 do Ministério da Justiça, que criou uma comissão com o propósito de elaborar um projeto de Lei de Mediação. Em 19 de agosto de 1992, foi editado o Decreto $\mathrm{n}^{\circ}$ 1.480/97, que estabeleceu os princípios básicos a serem adotados. Tal decreto não introduziu a mediação no sistema argentino, apenas propiciou a promulgação das leis sobre o tema. Por força de tal decreto, a mediação deveria ser um procedimento voluntário.

Em 14 de outubro de 1995 foi promulgada a Lei Federal argentina $n^{\circ}$ 24.573 (texto em anexo), que tornou a mediação obrigatória ${ }^{234}$. Por tal sistema, a mediação pode ser "libre o convencional", quando as partes escolhem um mediador dentre aqueles

\footnotetext{
${ }^{234}$ Art. $1^{\circ}$ : Art. $1^{\text {o: }}$ : Institúyese con carácter obligatorio la mediación previa a todo juicio, la que se regirá por las disposiciones de la presente ley. Este procedimiento promoverá la comunicación directa entre las partes la solución extrajudicial de la controvérsia".
} 
registrados no Ministério da Justiça $\left(\operatorname{art.} 1^{\circ}\right)^{235}$; ou legal, quando o procedimento é feito de acordo com o artigo $5^{\circ}$, onde a escolha do mediador é feita por sorteio entre os mediadores $^{236}$.

Para a referida lei, os mediadores são habilitados entre os advogados ${ }^{237}$ e o quadro de mediadores é subordinado ao Ministério de Justiça ${ }^{238}$. Os honorários do mediador são fixos e estabelecidos segundo critérios criados por normas editadas pelo Governo Federal.

$\mathrm{O}$ artigo $16^{\circ}$ da referida lei restringiu a habilitação do mediador à categoria dos advogados, o que a nosso ver não representa a melhor opção legislativa porquanto a Mediação é prática interdisciplinar em que a formação do mediador engloba conhecimentos de Psicologia, Sociologia, Administração e do Direito, pois o importante é que o mediador tenha conhecimento das origens e desdobramentos dos conflitos, tendo condições de auxiliar na compreensão dos mais variados níveis do conflito. O mediador deverá dispor, ainda, de instalações com ambiente adequado para a realização das sessões da mediação.

É grande a importância e o sucesso da mediação obrigatória na Argentina. Maria Inês Corrêa de Cerqueira César Targa nos informa que

em 1998, no Fórum Cível de Buenos Aires, foram propostas 134.984 ações, das quais 33.663 foram encaminhadas para mediação, tendo retornado ao sistema judiciário, para solução do litígio pelo meio da prolação da sentença, apenas 5.785 casos. O restante dos litígios foi encerrado pela efetivação de um acordo, derivado do processo de mediação, que pode utilizar até 60 dias. Realizado o acordo, o mesmo é homologado pelo Juiz e se transforma em Coisa Julgada. Não realizado o acordo, consigna-se singelamente na ata que ele não foi possível, não se registrando os motivos que o impediram, mantendo-se, assim, o sigilo necessário ao procedimento de mediação. ${ }^{239}$

\footnotetext{
${ }^{235}$ Art $1^{\text {o: }}$ "Las partes quedarán exentas del cumplimiento de este trámite si acreditaren que antes del inicio de la causa, existió mediación ante mediadores registrados por el Ministerio de Justicia".

${ }^{236}$ Art. 5 - "La mesa general de entradas entregará el formulario debidamente intervenido al presentante quien deberá remitirlo al mediador designado dentro del plazo de tres dias".

${ }^{237}$ LFA, Art. 16: "Para ser mediador será necesario poseer título de abogado y adquirir la capacitación requerida y restantes exigencias que se establezcan reglamentariamente".

${ }^{238}$ LFA, Art. 15: “Créase el Registro de Mediadores cuya constitución, organización, actualización, y administración será responsabilidad del Ministerio de Justicia de la Nación".

${ }^{239}$ TARGA, Maria Inês Correia de Cerqueira César. op. cit., p. 139.
} 


\subsubsection{França}

Antes da Lei de 8 de janeiro de 1995, que sistematizou a mediação na França, juízes inovadores introduziram a mediação no processo judicial fundamentando-se no art. 21 do novo Código de Processo Civil da França, que dá ao juiz a missão de conciliar as partes. A Corte de Cassação homologou tal prática da seguinte maneira: " $a$ mediação que permite assegurar, com a ajuda de um profissional, a confrontação dos respectivos pontos de vista das partes, para se alcançar um acordo, é uma modalidade do processo de conciliação ${ }^{240}$."

Com base em tal princípio, os Juízes de Família do Tribunal de Grande Instância de Nanterre decidiram, desde 1994, instalar dentro do Tribunal uma associação de mediação. Posteriormente, a Lei 95-125 de 8 de fevereiro de 1995, depois o Decreto de 22 de julho de 1996, trouxeram a base institucional para tal prática ${ }^{241}$.

Referida lei dispõe, ainda, que o custo da mediação é pago pelas partes, caso não haja outra convenção pré-estabelecida entre os interessados e o Juiz fixa o prazo no qual a mediação será tentada, período que pode ser prorrogado ou encerrado antes de seu termo, a requerimento das partes ou do mediador, ou, ainda, de ofício pelo Juiz.

A exemplo do que ocorre na lei da Argentina, o mediador se obriga a manter sigilo das informações recebidas no curso da mediação e, obtido o acordo, ele é submetido à homologação judicial.

No sistema francês, o mediador deverá ter conhecimento das técnicas de mediação, bem como rigoroso comportamento ético (pessoal e profissional), devendo atuar com independência, prudência e ampla dignidade no tratamento dispensado às partes. $\mathrm{O}$ anexo que acompanha o presente trabalho traz o Código de ética que deve ser respeitado.

\footnotetext{
${ }^{240}$ GANANCIA, Danièle. op. cit., p. 8.

${ }^{241}$ SIX, Jean-François. op. cit., p. 143-144. Segundo o autor, o artigo 21 da Lei 95-125 dispõe:

O juiz pode, depois de ter obtido o acordo das partes, designar uma terceira pessoa, que preencha as condições fixadas pelo decreto do Conselho de Estado para proceder:

1) Seja às tentativas prévias de conciliação prescritas pela lei, salvo em matéria de divórcio e separação de corpos;

2) Seja a uma mediação, em qualquer tempo do processo, compreendido em recurso de urgência, para tentar chegar a um acordo entre as partes

o juiz fixa o montante da provisão de remuneração do mediador e designa à ou às partes que consignarão a provisão dentro do prazo que ele determinar.

A designação do mediador caduca na falta de consignação dentro do prazo e segundo modalidades impostas. Prossegue-se, então, na instância.
} 


\subsubsection{Canadá}

No Canadá, a mediação pode ser realizada como audiência preliminar e é feita por um juiz diverso do que julgará a causa. A mediação pode ser voluntária ou obrigatória e o mediador é escolhido entre aqueles pertencentes aos quadros do Tribunal ou perante mediadores particulares. Os problemas de família são submetidos a serviços de mediação desde a década de 70, embora a lei referente a esse tipo de resolução só tenha sido promulgada em 1985. A exemplo do que ocorre na França, os mediadores sujeitam-se a um Código de Ética.

\subsubsection{Estados Unidos}

Nos Estados Unidos, o assunto já é mais antigo, existindo, inclusive, centros de excelência acadêmica como o Harvard Negotiation Project e o National Institute for Dispute Resolution, ambos localizados em Washington. Em 1980 o Congresso Americano aprovou o Dispute Resoluction Act, determinando, sob a administração do Departamento de Justiça, o estabelecimento de programas alternativos de solução em nível nacional, inclusive em Tribunais.

A utilização dos meios alternativos de solução dos conflitos surgiu como alternativa ao processo judicial, que demorava muito para ser resolvido. Como esclarece Edward P. Davis ${ }^{242}$, nos anos entre 1970 e 1980 houve um surto de processos nos Estados Unidos e as cortes americanas ficaram abarrotadas; as questões levavam mais de cinco anos para serem resolvidas na primeira instância. Como consequiência, os juízes, advogados e, principalmente, os litigantes ficavam cada vez mais frustrados com a demora na resolução de suas disputas e, conseqüentemente, a confiança no sistema judicial começou a perecer. Surgiu-se, assim, a onda das ADRs, alternative dispute resolution.

No entanto, como observa Petrônio Calmon ${ }^{243}$, formalmente, a experiência precursora com mecanismos para obtenção da autocomposição nos Estados Unidos ocorreu em 1913, com a criação do Departamento de Trabalho, onde foram

\footnotetext{
${ }^{242}$ DAVIS, Edward P. Mediação no direito comparado. Cadernos CEJ, n. 22, p. 16. Disponível em: $<$ http://www.cjf.gov.br/revista/seriecadernos/vol22/artigo02.pdf>.

${ }^{243}$ CALMON, Petrônio. op. cit., p. 175 e ss.
} 
instituídas comissões de conciliação para atender aos conflitos entre empregados e empregadores. Posteriormente, as referidas comissões se converteram no Serviço de Conciliação dos Estados Unidos, que, em 1947, foi transformado no Serviço Federal de Mediação e Conciliação ${ }^{244}$.

A utilização federal da mediação nos conflitos trabalhistas tornou-se exemplo seguido em muitos estados, que aprovaram leis e desenvolveram regulamentos e quadros de mediadores para resolver os conflitos trabalhistas locais. Como ressalta o autor acima referido, o setor privado também promoveu a mediação entre capital e trabalho e as relações comerciais. Como exemplo, a Associação Americana de Arbitragem, fundada em 1926, ocupava-se da mediação, antes de qualquer decisão heterocompositiva.

Desde os anos de 80, os programas de ADRs são implantados pelos tribunais estaduais norte-americanos e, atualmente, quase todos os Estados são atingidos. Com o objetivo de substituir o excessivo número de estatutos estaduais e federais referentes à mediação de conflitos, aproximadamente 2.500, firmou-se, em agosto de 2001, o Uniform Mediation Act - UMA, com o objetivo de regulamentar de maneira uniforme a mediação de $\operatorname{conflitos}^{245}$.

Os mecanismos privados de resolução de conflitos são praticados por profissionais liberais ou por instituições especializadas, que reúnem pessoas gabaritadas para essa tarefa. As instituições AAA-American Arbitration Association e JAMS - Judicial Arbitration e Mediation Services responsabilizam-se por todo o serviço de ADR. Tais entidades, como esclarece Petrônio Calmon, fornecem além de guias e regras, um catálogo de profissionais aos interessados. Possibilitam, ainda, o desenvolvimento do procedimento das ADRs em seus próprios prédios. Normalmente, um gestor de conflitos é nomeado por tais entiddes, com a finalidade de supervisionar o curso do procedimento.

Os mecanismos alternativos instalados nos tribunais federais são, ao contrário do que ocorre nas iniciativas privadas, amplamente estruturados e

\footnotetext{
${ }^{244}$ Segundo o autor, a justificativa foi impulsionar uma "paz industrial sólida e estável"e a "acomodação das relações entre empregadores e empregados mediante a negociação coletiva", com vistas a evitar a greve, melhorando a seguridade, o bem-estar e a riqueza dos norte-americanos.

${ }^{245}$ SALES, Lilia Maia de Morais. op. cit., p. 125. Ainda, como observa Petrônio Calmon na obra acima citada, "o objetivo da UMA é a difusão da mediação, encorajando as pessoas envolvidas em conflito a tomarem para si a responsabilidade e o poder de decidir seus próprios conflitos. A UMA trata particularmente das regras sobre o sigilo da mediação, orientando as partes a fixarem o compromisso de não revelarem o conteúdo das informações trocadas durante a mediação em eventual processo judicial sucessivo, bem como das regras de suspeição e impedimento do mediador e do direito à assistência de advogado, não obrigatória".
} 
regulamentados. No ano de 1990, foi editado pelo Congresso dos Estados Unidos o Civil Justice Reform Act, que determinou que os tribunais distritais federais desenvolvessem um plano objetivo para reduzir o tempo e as despesas dos processos no prazo de três anos. Cada distrito deveria designar um grupo, formado por advogados e litigantes, para identificar as causas e tendências do custo e demora do processo. Posteriormente, seriam definidas as diretrizes a serem seguidas pelos planos.

Em 1998 foi aprovado o Alternative Dispute Resolution Act, que determinou a adoção das ADRS pelos tribunais federais em todas as ações cíveis, dispondo, basicamente, que ao menos um tipo de ADR (mediação, arbitragem ou avaliação neutra) deve ser oferecido por cada tribunal, sendo obrigatório o oferecimento do mecanismo alternativo às partes, que, no entanto, não são obrigadas a participar. Funcionários específicos de cada Tribunal são encarregados de difundir os mecanismos oferecidos, além de recrutar e treinar os terceiros imparciais que neles atuarão. 


\section{CONCLUSÕES}

Pelo que foi desenvolvido no presente estudo, podemos concluir que os conflitos coletivos de trabalho são inerentes à própria relação e devem ser entendidos como naturais, e não como mera decorrência da chamada luta de classes. Eles não devem ser vistos como fator de desarmonia social, e sim como um meio que pode acarretar modificações e progressos nas relações capital/trabalho. As peculiaridades de tais conflitos exigem resoluções diferenciadas, que objetivam não apenas a solução da disputa, mas a efetiva pacificação dos envolvidos e, consequientemente, a permanência da relação continuada.

É necessário o desenvolvimento de novos modelos que possibilitem que as partes, por meio de um procedimento próprio e participativo, resolvam ou administrem suas disputas de maneira construtiva, inovadora, fortalecendo suas relações sociais, identificando interesses subjacentes ao conflito e explorando estratégias que possam prevenir ou resolver futuras controvérsias. A mediação, como forma de solução de conflitos voltada à autonomia das partes e ao incentivo da cultura da paz, pode ser validamente inserida e desenvolvida em tal âmbito.

Como ficou demonstrado, o conflito solucionado pelo sistema Judiciário pátrio, com sua lógica binária, não tem condições de compreender todos os aspectos dos problemas envolvidos, pois a racionalidade sistêmica manifestada pelo Poder Judiciário reduz a comunicação entre as partes conflitantes a uma linguagem técnica, que impede qualquer possibilidade de viver e entender a real dimensão do conflito. É necessário mudar o espírito do sistema jurídico, priorizando a lógica da comunicação e da negociação no lugar da lógica de confronto judicial, que normalmente exacerba o próprio conflito. A cultura jurídica que privilegia o paradigma ganhar/perder não é dirigida para neutralizar o dissenso e limita o espectro de soluções.

Assim, o modelo tradicional de jurisdição não resolve a lide sociológica; quando muito resolve a lide processual, já que as questões postas são dirimidas pontualmente. E quando não se atinge o cerne dos conflitos intersubjetivos, aumentam-se as chances de aparecerem novas disputas perante o Judiciário. 
A abordagem do conflito coletivo de trabalho num processo de mediação possibilita não apenas uma análise mais detalhada e real dos aspectos sócioeconômicos que interferem nas relações dos envolvidos, como também o exercício da autonomia e representatividade dos sujeitos coletivos. A administração dos conflitos de trabalho em um procedimento de mediação estimula a consciência coletiva, que é a base do movimento sindical e atua de forma educativa, de modo que os sujeitos envolvidos possam entender melhor suas aspirações, evitando futuros conflitos ou mantendo o diálogo entre as partes para que possam buscar soluções para próximas disputas.

O incentivo da mediação, como instrumento para resolução dos conflitos coletivos de trabalho pelos próprios interlocutores sociais, reflete o fortalecimento da autonomia sindical, com o conseqüente desafogo do judiciário trabalhista. Colabora, ainda, para a formação da cultura de pacificação dos conflitos, elementar às relações continuadas. Assim, mediante tal procedimento busca-se alinhar uma visão muito mais voltada para as relações interpessoais, tendo como premissa básica o relacionamento pós-conflito, diferente da visão mais comum do processo judicial, que visa ao passado e à resolução da controvérsia em si mesma.

Já está amplamente demonstrado, não só no Brasil como em outros países mais desenvolvidos, que o Estado não está aparelhado para atender as atuais necessidades da sociedade na solução de seus conflitos e para atuar como único agente de pacificação social. As modalidades alternativas para solução de conflitos têm crescido em todo o mundo e percebe-se que os países mais desenvolvidos, como os EUA, França e Canadá, entre outros, oferecem larga experiência na prática da utilização da mediação na prática da solução dos conflitos entre capital e trabalho.

Atualmente, o acesso à Justiça não está limitado ao acesso ao Poder Judiciário. O direito ao acesso à Justiça é, constitucionalmente, um direito fundamental que pode servir de ferramenta às organizações da sociedade civil para pressionar o Estado na busca da realização de políticas públicas eficientes, com vistas a disponibilizar à sociedade os instrumentos jurídicos necessários à aproximação do Direito da idéia de Justiça como força transformadora dos conflitos. Para existir uma efetiva proteção ao acesso à Justiça, é necessário o desenvolvimento de políticas públicas visando conscientizar a sociedade de seus direitos e deveres, estimulando-se, num ambiente pluralista, a utilização de formas alternativas de resolução dos conflitos. 
Mas o desenvolvimento da mediação, em todos os campos da vida social, não deve ser apresentado apenas como uma alternativa ao Judiciário, e sim como um novo modo de regulação social que prioriza a reconstrução das relações futuras e o respeito às suas necessidades específicas. E a profissionalização de seu procedimento, com a formação de mediadores com preparo técnico e eqüidistância, é condição que se faz necessária para aprimorar o papel que, atualmente, é basicamente cumprido pelo Poder Judiciário.

A convenção ou o acordo coletivo de trabalho obtido por meio da mediação exige um maior comprometimento das entidades sindicais, já que seus representantes necessitam intervir diretamente na busca da administração de seus conflitos. Tal procedimento possibilita uma maior aproximação das partes, uma vez que o mediador, pautando-se em suas técnicas, habilidades, princípios e condutas éticas, permite que os conflitos sejam tratados com uma maior compreensão em todos os seus aspectos, favorecendo que as discussões ocorram num ambiente propício e possibilitando um melhor atendimento das necessidades da classe trabalhadora e empresarial.

É importante e necessário atentar-se para a qualidade dos serviços de mediação, para que tal instituto não seja desacreditado, a exemplo do ocorre em relação às conciliações realizadas em algumas comissões de conciliação prévia. Por tal motivo, é fundamental o desenvolvimento de programas de capacitação de mediadores, da existência de instituições que promovam a fiscalização e o controle da qualidade dos serviços de mediação oferecidos, além de uma nova cultura nos próprios meios acadêmicos, voltada ao espírito do consenso.

Não basta a simples previsão legal para instituição de meios extrajudiciais de solução dos conflitos. É primordial a participação dos movimentos sindicais e dos próprios operadores do direito, para que todos tenham a consciência dos principais aspectos norteadores da mediação, principalmente no que diz respeito ao fato de que esta não será utilizada em substituição ao Judiciário. Ao contrário, um Judiciário forte e atuante é condição para que todos tenham plena autonomia de optar, ou não, pela utilização de tal meio autocompositivo.

Para tanto, é necessário o desenvolvimento de uma política nacional de incentivo à mediação voltada à construção de uma cultura da paz e ao efetivo acesso à Justiça, transformando o papel do Estado de extremo intervencionista, para o de incentivador e supervisor do diálogo dos envolvidos nos conflitos. Tal incentivo reforça a 
comunicação das partes e representa uma contribuição para o crescimento, para uma mudança nas condutas sociais e para a manutenção das relações continuadas. 


\section{REFERÊNCIAS BIBLIOGRÁFICAS}

ALCALÁ-ZAMORA Y CASTILLO, Niceto. Proceso, autocomposición y autodefensa: contribución al estudio de los fines del proceso. México: Ed. Universidad Autônoma Nacional do México, 1991.

AMARAL, Lídia Miranda de Lima. Mediação e arbitragem: uma solução para os conflitos trabalhistas no Brasil. São Paulo: LTr, 1994.

ANTEPROJETO de Lei sobre Mediação encampado pela OAB do Brasil. Boletim da Associação dos Advogados de São Paulo, São Paulo, n. 2.180, 9 a 15 p. 3-7, out. 2000.

ANTUNES, Ricardo L. C. O que é sindicalismo. São Paulo: Abril Cultural, 1985.

AZEVEDO, André Gomma. Estudos em arbitragem, mediação e negociação. Brasília: Ed. Grupos de Pesquisa, 2004. v. 3.

. O processo de negociação: uma breve apresentação de inovações epistemológicas em meios autocompositivos. Revista dos Juizados Especiais, Brasília, v. 5, n. 11, p. 13-24, jul./dez. 2001.

Processos construtivos: orientações prospectivas nos Juizados Especiais. Revista dos Juizados Especiais, Brasília, n. 16, jan./jun. 2004.

(Org.). Estudos em arbitragem, mediação e negociação. Brasília: Ed. Grupos de Pesquisa, 2004. v. 3.

BASTOS, Aurélio Wander. Conflitos sociais e limites do Poder Judiciário: subsídio metodológico para a compreensão do procedimento judiciário. Rio de Janeiro: Eldorado, 1975.

BELTRAN, Ari Possidonio. A autotutela nas relações de trabalho. São Paulo: LTr, 1996.

BERNARDES, Hugo Gueiros. O desenvolvimento da negociação coletiva no Brasil. LTr: revista legislação do trabalho. São Paulo, v. 54, n. 12, p. 1445-1449, dez. 1990.

. Princípios da negociação coletiva. In: TEIXEIRA FILHO, J. L. (Coord.). Relações coletivas de trabalho: estudos em homenagem ao Ministro Arnaldo Süssekind. São Paulo: LTr, 1989. p. 357-369. 
BOBBIO, Norberto; MATTEUCCI, Nicola; PASQUINO, Gianfranco. 12. ed. Dicionário de política. Brasília: Ed. da UnB, 2004. v. 1 e v. 2.

BOUDON, Raymond. Efeitos perversos e ordem social. Rio de Janeiro: Zahar, 1979.

BRITO FILHO, José Cláudio Monteiro de. Mediação e arbitragem como meios de solução de conflitos coletivos de trabalho: atuação do Ministério Publico do Trabalho. LTr: revista legislação do trabalho, São Paulo, v. 62, n. 3, p. 345-351, mar. 1998.

BUITONI, Ademir. A ilusão do normativismo e a mediação. Revista do Advogado, São Paulo, v. 26, n. 87, p. 109-114, set. 2006.

CALMON, Petrônio. Fundamentos da mediação e da conciliação. Rio de Janeiro: Forense, 2007.

CAPPELLETTI, Mauro. Os métodos alternativos de solução de conflitos no quadro do movimento universal de acesso a justiça. Tradução do inglês por J. C. Barbosa Moreira. Revista de Processo, São Paulo, v. 19, n. 74, p. 82-97, abr./jun. 1994.

Problemas de reforma do processo civil nas sociedades contemporâneas. Revista de Processo, São Paulo, v. 17, n. 65, p. 127-143, jan./mar. 1992.

; GARTH, Bryant. Acesso à justiça. Tradução de Ellen Gracie Northfleet. Porto Alegre: Fabris, 1998.

CARMONA, Carlos Alberto. A arbitragem no processo civil brasileiro. São Paulo: Malheiros Ed., 1993.

CARRION, Valentin. Comentários à CLT. 26. ed. São Paulo: Saraiva, 2001.

CENTRO BRASILEIRO DE ESTUDOS E PESQUISAS JUDICIAIS. Disponível em: $<w w w . c e b e p e j . o r g . b r .>$.

CINTRA, Antônio Carlos Araújo; DINAMARCO, Cândido Rangel; GRINOVER, Ada Pelegrini. Teoria geral do processo. 14. ed. São Paulo: Malheiros Ed., 1998.

COMITÊ PAULISTA PARA A DÉCADA DA CULTURA DE PAZ. Disponível em: <http://www.comitepaz.org.br/a_cultura_de_p.htm>. Acesso em: 12 dez. 2006.

CONIMA - Conselho Nacional das Instituições de Mediação e Arbitragem. Disponível em: $<$ www.conima.org.br>. 
CONSELHO NACIONAL DE JUSTIÇA. Movimento pela conciliação. Projeto Conciliar. Disponível em: <http://www.conciliar.cnj.gov.br/cms/verTexto.asp?pagina=projeto>.

CÓRDOBA, Éfren. As relações coletivas do trabalho na América Latina. São Paulo: LTr, 1985.

DAHRENDORF, Ralf. Las classes sociales e su conflicto en la sociedad industrial. Madrid: Ediciones Rialp, 1970.

. Elementos para uma teoria do conflito social. In: Sociedade e liberdade. Brasília: Ed. da UnB, 1981.

DAVIS, Edward P. Mediação no direito comparado. Cadernos CEJ, n. 22, p. 16. Disponível em: <http://www.cjf.gov.br/revista/seriecadernos/vol22/artigo02.pdf>.

DELGADO, Maurício Godinho. Arbitragem, mediação e comissão de conciliação prévia no direito do trabalho brasileiro. LTr: revista legislação do trabalho, São Paulo, v. 66, n. 6, p. 663-670, jun. 2002.

DINAMARCO, Cândido Rangel. Instituições de direito processual civil. São Paulo : Malheiros Ed., 2003.

A instrumentalidade do processo. 12. ed. São Paulo: Malheiros Ed., 2005.

FARIA, José Eduardo. Os novos desafios da justiça do trabalho. São Paulo: LTr, 1995. (Org.) Direito e justiça: a função social do Judiciário. São Paulo: Ática, 1989. . A crise do Judiciário no Brasil: algumas notas para discussão. Separata da Revista do Ministério Público, Lisboa, n. 89, 2002.

FAVA, Marcos Neves. Comissões de conciliação prévia e crime de frustração de direito trabalhista. Disponível em: <http://www.trt02.gov.br/geral/tribunal2/Legis/CLT/Doutrina>. Acesso em: 10 jan. 2007.

FIGUEIROA JUNIOR, Narciso. As recentes alterações na legislação trabalhista: leis ns. 9.957 e 9.958 de 12 de janeiro de 2000. LTr: revista legislação do trabalho, São Paulo, v. 64, n. 2, p. 197-200, fev. 2000. 
FIORELLI, José Osmir; MALHADAS JÚNIOR, Marcos Júlio Olivé. Psicologia nas relações do trabalho: uma nova visão para advogados, juízes do trabalho, administradores e psicólogos. São Paulo: LTr, 2003.

; ___ _ MORAES, Daniel Lopes de. Psicologia na mediação: inovando a gestão de conflitos interpessoais e organizacionais. São Paulo: LTr, 2004.

FOLBERG, J., TAYLOR, A. Mediación: resolución de conflictos sin litigio. Buenos Aires: Noriega, 1984.

FREITAS JÚNIOR, Antonio Rodrigues. Direito sindical e controle corporativo: a insuficiência das proposições atualmente em debate. In: Os direitos sociais e a Constituição de 1988: economia e políticas de bem-estar”. Rio de Janeiro: Forense, 1993.

Mediação de conflitos: (Justiça pública não-judiciária e promoção da cultura da paz). Revista do Departamento de Direito do Trabalho e da Seguridade Social, São Paulo, v. 1, n. 2, 2006.

Sindicato: domesticação e ruptura: um estudo da representação sindical no direito brasileiro. São Paulo: Ordem dos Advogados do Brasil, Departamento Editorial, 1989.

GAJARDONI, Fernando da Fonseca. Técnicas de aceleração do processo. São Paulo: Lemos \& Cruz, 2003.

GANANCIA, Danièle. Justiça e mediação familiar: uma parceria da co-parentalidade. Revista do Advogado, São Paulo, n .62, p. 7-15, mar. 2001.

GASPARI, Elio. Folha de S. Paulo, São Paulo, 04 fev. 2007.

GIGLIO, Wagner. Direito processual do trabalho. São Paulo: LTr, 1994.

GIUGNI, Gino. Giuridificazione e deregolazione nel diritto del lavoro italiano. In: Lavoro legge: contratti. Bologna: Il Mulino, 1989. p. 317-241.

GRAU, Eros Roberto. O direito posto e o direito pressuposto. São Paulo: Malheiros Ed., 1996.

GRINOVER, Ada Pelegrini. Modernidade do direito processual brasileiro. Revista da Faculdade de Direito da Universidade de São Paulo, São Paulo, v. 88, p. 273-298, jan./dez. 1993. 
GRINOVER, Ada Pelegrini. Os fundamentos da justiça conciliativa. In: WATANABE, Kazuo, LAGRASTA NETO, Caetano. Mediação e gerenciamento do processo: revolução na prestação jurisdicional: guia prático para a instalação do setor de conciliação e arbitragem. São Paulo: Atlas, 2007.

HABERMAS, Jürgen. Teoría de la acción comunicativa. 4. ed. Madrid: Taurus, 2003. v. 1 e 2 .

HUSEK, Carlos Roberto. Jornal Gazeta, out. 2000.

ISSLER, Daniel. O Projeto de Mediação da Vara da Infância e Juventude de GuarulhosSP (Parceria Unimesp/FIG). In: GRINOVER, Ada Pelegrini; WATANABE, Kazuo, LAGRASTA NETO, Caetano. Mediação e gerenciamento do processo: revolução na prestação jurisdicional: guia prático para a instalação do setor de conciliação e arbitragem. São Paulo: Atlas, 2007. p. 84-86.

MAGANO, Octavio Bueno. Manual de direito do trabalho: direito coletivo do trabalho. 2. tir. São Paulo: LTr, 1986. v. 3.

; MALLET, Estêvão. O direito do trabalho na Constituição. Rio de Janeiro: Forense, 1993.

MANUAL do Mediador. Brasília: MTb, SRT, 1996.

MARTINS, José Celso. Arbitragem, mediação e conflitos coletivos do trabalho. LTr: São Paulo, 2005.

MAYER, Bernard. The dynamics of conflitct resolution: a practticioner's guide. San Francisco: Jossey-Bass, 2000.

MICHELON, Regina Maria Coelho. A mediação dos conflitos trabalhistas. In: OLIVEIRA, Ângela. Mediação: métodos de resolução de controvérsias. São Paulo: LTr, 1999.

MOORE, Christopher. O processo de mediação. Trad. Magda França Lopes. Porto Alegre: ED. Artmed, 1998.

NASCIMENTO, Amauri Mascaro. Compêndio de direito sindical. São Paulo: LTr, 2005. Compêndio de direito sindical. 4. ed. São Paulo: LTr, 2006. 
NASCIMENTO, Amauri Mascaro. Conflitos coletivos de trabalho. São Paulo: Saraiva, 1978.

. O debate sobre negociação coletiva. LTr: revista legislação do trabalho, São Paulo, v. 64, n. 9, p. 1105-1122, set. 2000.

Iniciação do direito do trabalho. 6. ed. São Paulo: LTr, 1980.

ORGANIZAÇÃO INTERNACIONAL DO TRABALHO - OIT. A liberdade sindical. Trad. Edílson Alkmin Cunha. São Paulo: LTr, 1993.

. Negociações coletivas. São Paulo: LTr; Brasília: OIT, 1994.

PAOLI, Maria Célia. Revista USP.

PINTO, José Augusto Rodrigues. Direito sindical e coletivo do trabalho. São Paulo: LTr, 1998.

PLÁ RODRIGUES, Américo. A solução dos conflitos trabalhistas: perspectivas iberoamericanas. Coord. Nestor de Buen). São Paulo: LTr, 1986.

PROGRAMA de Estímulo à Mediação. Tribunal de Justiça do Distrito Federal. Disponível em: <http://www.tjdft.gov.br/tribunal/institucional/prog_estimulo_mediacao/guia/guia.pdf>.

RAIFFA, H.; RICHARDSON, J.; METCALFE, D. Negotiation análisis: the sciense and art of collaborative decisión making. Cambridge: Harvard University Press, 2002.

RAMOS FILHO, Wilson. O fim do poder normativo e a arbitragem. São Paulo: LTr, 1999.

RANDS, Mauricio. As comissões de conciliação previa. LTr: revista legislação do trabalho. São Paulo, v. 64, n. 4, p. 465-467, abr. 2000.

ROMITA, Arion Sayão. Equidade e dissídios coletivos. Rio de Janeiro: Ed. Brasília, 1976. O poder normativo da Justiça do Trabalho: a necessária reforma. Disponível em: <www.planalto.gov.br/ccivil_03/revista/Rev_22/artigos/art_arion.htm>. Acesso em: 3 jan. 2008 .

RUPRECHT, Alfredo. Conflitos coletivos de trabalho. Trad. José Luiz Ferreira Prunes. São Paulo: LTr, 1979. 
RUSSOMANO, Mozart Victor. Comentários à Consolidação das Leis do Trabalho. 16. ed. Rio de Janeiro: Forense, 1994. v. 2.

. Conflitos coletivos de trabalho. São Paulo: Ed. Revista dos Tribunais, 1979. Princípios gerais de direto sindical. 2. ed. Rio de Janeiro: Forense, 1995.

SÁ, Maria Cristina Haddad de. Negociação coletiva de trabalho no Brasil. São Paulo: LTr, 2002 .

SADEK, Maria Tereza. Judiciário: mudanças e reformas. Estudos Avançados, São Paulo, v. 18, n. 51, p. 79-101, maio/ago. 2004.

SALA FRANCO, Tomas. Los procedimentos extrajudiciales de solucion de los conflictos laborales estabelecidos em la negociacion coletiva. Valencia: Tirant lo Blanch, 1996.

SALES, Lilia Maia de Morais. Justiça e mediação de conflitos. Belo Horizonte: Del Rey, 2004.

SALOMÃO, Aparício Quirino. A mediação de conflitos coletivos no Ministério do Trabalho. LTr: legislação do trabalho. Suplemento trabalhista, São Paulo, n. 113, p. 521$523,1998$.

SANTOS, Enoque Ribeiro dos. Direitos humanos na negociação coletiva: teoria e prática jurisprudencial. São Paulo: LTr, 2004.

SERPA, Maria de Nazareth. Teoria e prática da mediação de conflitos. Rio de Janeiro: Lúmen Júris, 1999.

SILVA, Otávio Pinto e. A contratação coletiva como fonte de direito do trabalho. São Paulo: LTr, 1998.

—. Subordinação, autonomia e parassubordinação nas relações coletivas de trabalho. São Paulo: LTr, 2004.

SILVA, Ovídio A. Baptista. Democracia moderna e processo civil. In: GRINOVER, Ada Pelegrini; DINAMARCO, Cândido Rangel; WATANABE, Kazuo (Coords.). Processo e participação. São Paulo: Ed. Revista dos Tribunais, 1988.

SIMITS, Spiros. La giuridificazione dei rapporti di lavoro. DLRI, n. 30, p. 215-276, 1986. 
SIQUEIRA NETO, José Francisco. Contrato coletivo de trabalho: perspectiva de rompimento com a legalidade repressiva. São Paulo: LTr, 1991.

Direito do trabalho \& democracia: apontamento e pareceres. São Paulo: LTr, 1996.

A modernidade necessária. In: FÓRUM NACIONAL SOBRE CONTRATO

COLETIVO E RELAÇÕES DO TRABALHO NO BRASIL. Brasília: Ministério do

Trabalho, 1994.

SIX, Jean-François. Dinâmica da mediação. Tradução de Águida Arruda Barbosa, Eliana Riberti Nazareth, Giselle Groeninga. Belo Horizonte: Del Rey, 2001.

SOUZA, Rosane Mantilla de. Mediação social: uma experiência de trabalho em comunidade de baixa renda. In: MUSZKAT, Malvina Ester (Org.). Mediação de conflitos: pacificando e prevenindo a violência. São Paulo: Summus, 2003.

SUARES, Marines. Mediación: conducción de disputas, comunicación y técnicas. Buenos Aires: Piados, 1997.

TARGA, Maria Inês Correia de Cerqueira César. Mediação em juízo. São Paulo: LTr, 2004.

TEIXEIRA FILHO, João de Lima; SÜSSEKIND, Arnaldo; MARANHÃO, Délio; VIANNA, Segadas. Instituições de direito do trabalho. São Paulo: LTr, 2000. v. 2.

URY, William; PATTON, Bruce. Como chegar ao sim: negociação de acordos sem concessões. Tradução Vera Ribeiro \& Ana Luiza Borges. 2. ed. Rio de Janeiro: Imago Ed., 1994.

VEZZULA, J. Teoria e prática da mediação. Florianópolis: IMAB, 2001.

VOESE, Ingo. Mediação dos conflitos como negociação de sentidos. Curitiba: Juruá, 2005.

WARAT, Luis Alberto. Em nome do acordo: a mediação no direito. In: (Org.). Ecologia, psicanálise e mediação. Buenos Aires: Associação Latino- Americana de Mediação, Metodologia e Ensino do Direito, 1999. O ofício do mediador. Florianópolis: Habitus, 2001. v. 1. 
WATANABE, Kazuo. Cultura da sentença e cultura da pacificação. In: TARSHELL, Flávio Luiz; MORAES, Maurício Zanoide de (Orgs.). Estudos em Homenagem à Professora Ada Pellegrini Grinover. São Paulo: Ed. DPJ, 2005.

WEBER, Max. Economia e sociedade. 3. ed. Trad. Régis Barbosa e Karen Elsabe Barbosa. 5. ed. Brasília: Ed. da UnB, 1994. v. 1.

ZAPPAROLLI, Célia Regina. A experiência pacificadora da mediação: uma alternativa contemporânea para a implementação da cidadania e da justiça. In: MUSZKAT, Malvina Ester (Org.). Mediação de conflitos: pacificando e prevenindo a violência. São Paulo: Summus, 2003. 

Ofício $\mathrm{n}^{\circ} \quad 4312$
(SF)
Brasília, em $/ 2$ de julho de 2006.

A Sua Excelência o Senhor Deputado Inocêncio Oliveira

Primeiro-Secretário da Câmara dos Deputados

Assunto: Substitutivo do Senado a Projeto de Lei da Câmara.

Senhor Primeiro-Secretário,

Comunico a Vossa Excelência que o Senado Federal aprovou, em revisão, nos termos do substitutivo em anexo, o Projeto de Lei da Câmara ${ }^{\circ} 94$, de 2002 (PL n ${ }^{\circ} 4.827$, de 1998, nessa Casa), que "Institucionaliza e disciplina a mediação, como método de prevenção e solução consensual de conflitos", que ora encaminho para apreciação dessa Casa.

Atenciosamente,

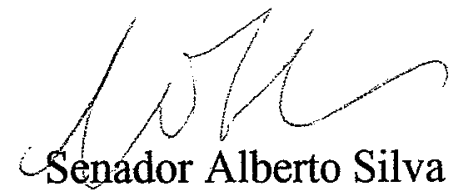

no exercício da Primeira Secretaria

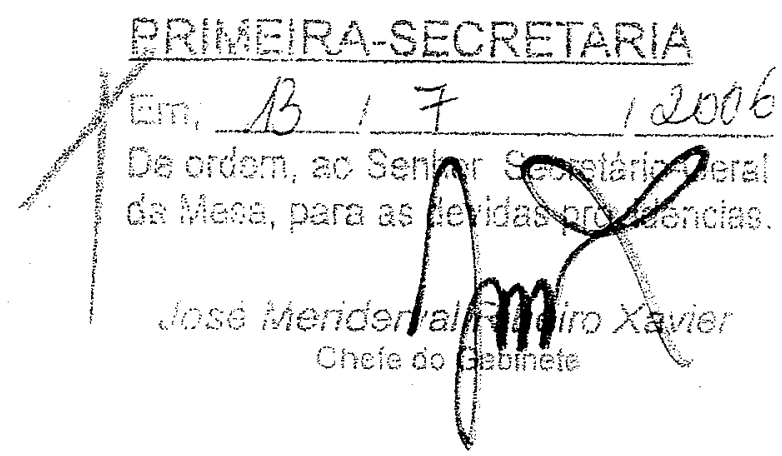


Substitutivo do Senado ao Projeto de Lei da Câmara no 94, de 2002 (PL n 4.827, de 1998, na Casa de origem) que "Institucionaliza e disciplina a mediação, como método de prevenção e solução consensual de conflitos".

Substitua-se o Projeto pelo seguinte:

Institucionaliza e disciplina a mediação, como método de prevenção e solução consensual de conflitos na esfera civil, e dá outras providências.

\section{O Congresso Nacional decreta:}

\section{CAPÍTULO I \\ DISPOSIÇÕES GERAIS} natureza civil.

Art. $1^{\circ}$ Esta Lei institui e disciplina a mediação paraprocessual nos conflitos de

Art. $2^{\circ}$ Para fins desta Lei, mediação é a atividade técnica exercida por terceiro imparcial que, escolhido ou aceito pelas partes interessadas, as escuta, orienta e estimula, sem apresentar soluções, com o propósito de lhes permitir a prevenção ou solução de conflitos de modo consensual.

Art. $3^{\circ} \mathrm{A}$ mediação paraprocessual será prévia ou incidental, em relação ao momento de sua instauração, e judicial ou extrajudicial, conforme a qualidade dos mediadores.

Art. $4^{0}$ É lícita a mediação em toda matéria que admita conciliação, reconciliação, transação ou acordo de outra ordem.

Art. $5^{\circ}$ A mediação poderá versar sobre todo o conflito ou parte dele.

Art. $6^{\circ}$ A mediação será sigilosa, salvo estipulação expressa em contrário pelas partes, observando-se, em qualquer hipótese, o disposto nos arts. 13 e 14.

Art. $7^{\circ} \mathrm{O}$ acordo resultante da mediação se denominará termo de mediação e deverá ser subscrito pelo mediador, judicial ou extrajudicial, pelas partes e advogados, constituindo-se título executivo extrajudicial.

Parágrafo único. A mediação prévia, desde que requerida, será reduzida a termo e homologada por sentença, independentemente de processo.

Art. $8^{\circ}$ A pedido de qualquer um dos interessados, o termo de mediação obtido na mediação prévia ou incidental, poderá ser homologado pelo juiz, caso em que terá eficácia de título executivo judicial. 


\section{CAPÍTULO II DOS MEDIADORES}

Art. $9^{\circ}$ Pode ser mediador qualquer pessoa capaz, de conduta ilibada e com formação técnica ou experiência prática adequada à natureza do conflito, nos termos desta Lei.

Art. 10. Os mediadores serão judiciais ou extrajudiciais.

Art. 11. São mediadores judiciais os advogados com pelo menos 3 (três) anos de efetivo exercício de atividades jurídicas, capacitados, selecionados e inscritos no Registro de Mediadores, na forma desta Lei.

Art. 12. São mediadores extrajudiciais aqueles independentes, selecionados e inscritos no respectivo Registro de Mediadores, na forma desta Lei.

Art. 13. Na mediação paraprocessual, os mediadores judiciais ou extrajudiciais e os co-mediadores são considerados auxiliares da justiça, e, quando no exercício de suas funções, e em razão delas, são equiparados aos funcionários públicos, para os efeitos da lei penal.

Art. 14. No desempenho de suas funções, o mediador deverá proceder com imparcialidade, independência, aptidão, diligência e confidencialidade, salvo, no último caso, por expressa convenção das partes.

Art. 15. Caberá, em conjunto, à Ordem dos Advogados do Brasil, ao Tribunal de Justiça, à Defensoria Pública e às instituições especializadas em mediação devidamente cadastradas na forma do Capítulo III, a formação e seleção de mediadores, para o que serão implantados cursos apropriados, fixando-se os critérios de aprovação, com a publicação do regulamento respectivo.

Art. 16. É lícita a co-mediação quando, pela natureza ou pela complexidade do conflito, for recomendável a atuação conjunta do mediador com outro profissional especializado na área do conhecimento subjacente ao litígio.

$\S 1^{\circ} \mathrm{A}$ co-mediação será obrigatória nas controvérsias submetidas à mediação que versem sobre o estado da pessoa e Direito de Família, devendo dela necessariamente participar psiquiatra, psicólogo ou assistente social.

$\S 2^{\circ}$ A co-mediação, quando não for obrigatória, poderá ser requerida por qualquer dos interessados ou pelo mediador.

\section{CAPÍTULO III \\ DO REGISTRO DE MEDIADORES E DA FISCALIZAÇÃO E CONTROLE DA ATIVIDADE DE MEDIAÇÃO}

Art. 17. O Tribunal de Justiça local manterá Registro de Mediadores, contendo relação atualizada de todos os mediadores habilitados a atuar prévia ou incidentalmente no âmbito do Estado.

$\S 1^{\circ}$ Os Tribunais de Justiça expedirão normas regulamentando o processo de inscrição no Registro de Mediadores. 
$\S 2^{\circ} \mathrm{A}$ inscrição no Registro de Mediadores será requerida ao Tribunal de Justiça local, na forma das normas expedidas para este fim, pelos que tiverem cumprido satisfatoriamente os requisitos do art. 15 desta Lei.

$\S 3^{\circ}$ Do registro de mediadores constarão todos os dados relevantes referentes à atuação do mediador, segundo os critérios fixados pelo Tribunal de Justiça local.

$\S 4^{\circ}$ Os dados colhidos na forma do $\S 3^{\circ}$ serão classificados sistematicamente pelo Tribunal de Justiça, que os publicará anualmente para fins estatísticos.

$\S 5^{\circ}$ No caso de atuação de defensor público como mediador, o registro, a fiscalização e o controle da atividade serão realizados pela Defensoria Pública.

Art. 18. Na mediação extrajudicial, a fiscalização das atividades dos mediadores e co-mediadores competirá sempre ao Tribunal de Justiça do Estado, na forma das normas específicas expedidas para este fim.

Art. 19. Na mediação judicial, a fiscalização e controle da atuação do mediador será feita pela Ordem dos Advogados do Brasil, por intermédio de suas seccionais; a atuação do co-mediador será fiscalizada e controlada pelo Tribunal de Justiça.

Art. 20. Se a mediação for incidental, a fiscalização também caberá ao juiz da causa, que, verificando a atuação inadequada do mediador ou do co-mediador, poderá afastá-lo de suas atividades relacionadas ao processo, e, em caso de urgência, tomar depoimentos e colher provas, dando notícia, conforme o caso, à Ordem dos Advogados do Brasil ou ao Tribunal de Justiça, para as medidas cabíveis.

Art. 21. Aplicam-se aos mediadores e co-mediadores os impedimentos previstos nos arts. 134 e 135 do Código de Processo Civil.

$\S 1^{\circ}$ No caso de impedimento, o mediador devolverá os autos ao distribuidor, que designará novo mediador; se a causa de impedimento for apurada quando já iniciado o procedimento de mediação, o mediador interromperá sua atividade, lavrando termo com o relatório do ocorrido e solicitará designação de novo mediador ou co-mediador.

$\S 2^{\circ} \mathrm{O}$ referido relatório conterá:

I - nomes e dados pessoais das partes envolvidas;

II - indicação da causa de impedimento ou suspeição;

III - razões e provas existentes pertinentes do impedimento ou suspeição.

Art. 22. No caso de impossibilidade temporária do exercício da função, o mediador informará o fato ao Tribunal de Justiça, para que, durante o período em que subsistir a impossibilidade, não lhe sejam feitas novas distribuições.

Art. 23. O mediador fica absolutamente impedido de prestar serviços profissionais a qualquer das partes, em matéria correlata à mediação; o impedimento terá o prazo de 2 (dois) anos, contados do término da mediação, quando se tratar de outras matérias.

Art. 24. Considera-se conduta inadequada do mediador ou do co-mediador a sugestão ou recomendação acerca do mérito ou quanto aos termos da resolução do conflito, assessoramento, inclusive legal, ou aconselhamento, bem como qualquer forma explícita ou implícita de coerção para a obtenção de acordo.

Art. 25. Será excluído do Registro de Mediadores aquele que:

I - assim o solicitar ao Tribunal de Justiça, independentemente de justificação; 
suspeição;

II - agir com dolo ou culpa na condução da mediação sob sua responsabilidade;

III - violar os princípios de confidencialidade e imparcialidade;

IV - funcionar em procedimento de mediação mesmo sendo impedido ou sob

$\mathrm{V}$ - sofrer, em procedimento administrativo realizado pela Ordem dos Advogados do Brasil, pena de exclusão do Registro de Mediadores;

VI - for condenado, em sentença criminal transitada em julgado.

$\S 1^{\circ}$ Os Tribunais de Justiça dos Estados, em cooperação, consolidarão mensalmente relação nacional dos excluídos do Registro de Mediadores.

$\S 2^{\circ}$ Salvo no caso do inciso $I$, aquele que for excluído do Registro de Mediadores não poderá, em hipótese alguma, solicitar nova inscrição em qualquer parte do território nacional ou atuar como co-mediador.

Art. 26. O processo administrativo para averiguação de conduta inadequada do mediador poderá ser iniciado de ofício ou mediante representação e obedecerá ao procedimento estabelecido pelo Tribunal de Justiça local.

Art. 27. O processo administrativo conduzido pela Ordem dos Advogados do Brasil obedecerá ao procedimento previsto no Título III da Lei $n^{\circ} 8.906$, de 4 de julho de 1994, podendo ser aplicada desde a pena de advertência até a exclusão do Registro de Mediadores.

Parágrafo único. $\mathrm{O}$ processo administrativo a que se refere o caput será concluído em, no máximo, 90 (noventa) dias, e suas conclusões enviadas ao Tribunal de Justiça para anotação no registro do mediador ou seu cancelamento, conforme o caso.

Art. 28. O co-mediador afastado de suas atividades nos termos do art. 19, desde que sua conduta inadequada seja comprovada em regular procedimento administrativo, fica impedido de atuar em novas mediações pelo prazo de 2 (dois) anos.

\section{CAPÍTULO IV \\ DA MEDIAÇÃO PRÉVIA}

Art. 29. A mediação prévia pode ser judicial ou extrajudicial.

Parágrafo único. O requerimento de mediação prévia interrompe a prescrição e deverá ser concluído no prazo máximo de 90 (noventa) dias.

Art. 30. $O$ interessado poderá optar pela mediação prévia judicial, caso em que o requerimento adotará formulário padronizado, subscrito por ele ou por seu defensor público ou advogado, sendo, no último caso, indispensável a juntada do instrumento de mandato. imediatamente.

$\S 1^{\mathrm{o}}$ Distribuído ao mediador, o requerimento ser-lhe-á encaminhado

$\S 2^{\circ}$ Recebido o requerimento, o mediador designará dia, hora e local onde realizará a sessão de mediação, dando ciência aos interessados por qualquer meio eficaz e idôneo de comunicação.

$\S 3^{\circ} \mathrm{A}$ cientificação ao requerido conterá a recomendação de que deverá comparecer à sessão acompanhado de advogado, quando a presença deste for indispensável. Neste caso, não tendo o requerido constituído advogado, o mediador solicitará à Defensoria 
Pública ou, na falta desta, à Ordem dos Advogados do Brasil a designação de advogado dativo. Na impossibilidade de pronto atendimento à solicitação, o mediador imediatamente remarcará a sessão, deixando os interessados já cientificados da nova data e da indispensabilidade dos advogados.

$\S 4^{\circ}$ Os interessados, de comum acordo, poderão escolher outro mediador, judicial ou extrajudicial.

$\S 5^{\circ}$ Não sendo encontrado o requerido, ou não comparecendo qualquer das partes, estará frustrada a mediação.

Art. 31. Obtido ou não o acordo, o mediador lavrará o termo de mediação, descrevendo detalhadamente todas as cláusulas do mesmo ou consignando a sua impossibilidade.

Parágrafo único. $\mathrm{O}$ mediador devolverá o requerimento ao distribuidor, acompanhado do termo de mediação, para as devidas anotações.

Art. 32. A mediação prévia extrajudicial, a critério dos interessados, ficará a cargo de mediador independente ou daquele ligado à instituição especializada em mediação.

Art. 33. Em razão da natureza e complexidade do, conflito, o mediador judicial ou extrajudicial, a seu critério ou a pedido de qualquer das partes, prestará seus serviços em regime de co-mediação com profissional especializado em outra área que guarde afinidade com a natureza do conflito.

\section{CAPÍTULO V \\ DA MEDIAÇÃO INCIDENTAL}

Art. 34. A mediação incidental será obrigatória no processo de conhecimento, salvo nos seguintes casos:

I - na ação de interdição;

II - quando for autora ou ré pessoa de direito público e a controvérsia versar sobre direitos indisponíveis;

III - na falência, na recuperação judicial e na insolvência civil;

IV - no inventário e no arrolamento;

$\mathrm{V}$ - nas ações de imissão de posse, reivindicatória e de usucapião de bem imóvel;

VI - na ação de retificação de registro público;

VII - quando o autor optar pelo procedimento do juizado especial ou pela arbitragem;

VIII - na ação cautelar;

IX - quando na mediação prévia, realizada na forma do Capítulo IV, tiver ocorrido sem acordo nos 180 (cento e oitenta) dias anteriores ao ajuizamento da ação.

Parágrafo único. A mediação deverá ser realizada no prazo máximo de 90 (noventa) dias e, não sendo alcançado o acordo, dar-se-á continuidade ao processo.

Art. 35. Nos casos de mediação incidental, a distribuição da petição inicial ao juízo interrompe a prescrição, induz litispendência e produz os demais efeitos previstos no art. 263 do Código de Processo Civil.

$\S 1^{\circ}$ Havendo pedido de liminar, a mediação terá curso após a respectiva decisão. 

de mediação.

$\S 2^{\circ}$ A interposição de recurso contra a decisão liminar não prejudica o processo

Art. 36. A designação inicial será de um mediador, judicial ou extrajudicial, a quem será remetida cópia dos autos do processo judicial.

Parágrafo único. As partes, de comum acordo, poderão escolher outro mediador, judicial ou extrajudicial.

Art. 37. Cabe ao mediador intimar as partes por qualquer meio eficaz e idôneo de comunicação, designando dia, hora e local para seu comparecimento.

$\S 1^{\circ} \mathrm{A}$ intimação deverá conter a recomendação de que as partes deverão se fazer acompanhar de advogados, quando indispensável à assistência judiciária.

$\S 2^{\circ}$ Se o requerido não tiver sido citado no processo judicial, a intimação para a sessão de mediação constitui-lo-á em mora, tornando prevento o juízo, induzindo litispendência, fazendo litigiosa a coisa e interrompendo a prescrição.

$\S 3^{\circ} \mathrm{Se}$ qualquer das partes não tiver advogado constituído nos autos do processo judicial, o mediador procederá de acordo com o disposto na parte final do $\S 3^{\circ}$ do art. 30 .

$\S 4^{\circ}$ Não sendo encontrado o requerido, ou não comparecendo qualquer das partes, estará frustrada a mediação.

Art. 38. Na hipótese de mediação incidental, ainda que haja pedido de liminar, a antecipação das despesas do processo, a que alude o art. 19 do Código de Processo Civil, somente será devida após a retomada do curso do processo, se a mediação não tiver resultado em acordo ou conciliação.

Parágrafo único. O valor pago a títulos de honorários do mediador, na forma do art. 19 do Código de Processo Civil, será abatido das despesas do processo.

Art. 39. Obtido ou frustrado o acordo, o mediador lavrará o termo de mediação descrevendo detalhadamente todas as cláusulas do acordo ou consignando sua impossibilidade.

$\S 1^{\circ} \mathrm{O}$ mediador devolverá a petição inicial ao juiz da causa, acompanhada do termo, para que seja dado prosseguimento ao processo.

$\S 2^{\circ}$ Ao receber a petição inicial acompanhada do termo de transação, o juiz determinará seu imediato arquivamento ou, frustrada a transação, providenciará a retomada do processo judicial.

Art. 40. Havendo acordo, o juiz da causa, após verificar o preenchimento das formalidades legais, homologará o acordo por sentença.

Parágrafo único. Se o acordo for obtido quando o processo judicial estiver em grau de recurso, a homologação do mesmo caberá ao relator.

\section{CAPÍTULO VI \\ DISPOSIÇÕES FINAIS}

Art. 41. A mediação será sempre realizada em local de fácil acesso, com estrutura suficiente para atendimento condigno dos interessados, disponibilizado por entidade pública ou particular para o desenvolvimento das atividades de que trata esta Lei. 
Parágrafo único. O Tribunal de Justiça local fixará as condições mínimas a que se refere este artigo.

Art. 42. Os serviços do mediador serão sempre remunerados, nos termos e segundo os critérios fixados pela norma local.

Parágrafo único. Nas hipóteses em que for concedido o benefício da assistência judiciária, estará a parte dispensada do recolhimento dos honorários, correndo as despesas às expensas de dotação orçamentária do respectivo Tribunal de Justiça.

Art. 43. O art. 331 da Lei $\mathrm{n}^{\circ}$ 5.869, de 1973, Código de Processo Civil, passa a vigorar com a seguinte redação:

"Art. 331. Se não se verificar qualquer das hipóteses previstas nas seções precedentes, o juiz designará audiência preliminar, a realizar-se no prazo máximo de 30 (trinta) dias, para a qual serão as partes intimadas a comparecer, podendo fazer-se representar por procurador ou preposto, com poderes para transigir.

$\S 1^{\circ} \mathrm{Na}$ audiência preliminar, o juiz ouvirá as partes sobre os motivos e fundamentos da demanda e tentará a conciliação, mesmo tendo sido realizada a tentativa de mediação prévia ou incidental.

$\S 2^{\circ}$ A lei local poderá instituir juiz conciliador ou recrutar conciliadores para auxiliarem o juiz da causa na tentativa de solução amigável dos conflitos.

$\S 3^{\circ}$ Segundo as peculiaridades do caso, outras formas adequadas de solução do conflito poderão ser sugeridas pelo juiz, inclusive a arbitragem, na forma da lei, a mediação e a avaliação neutra de terceiro.

$\S 4^{\circ}$ A avaliação neutra de terceiro, a ser obtida no prazo a ser fixado pelo juiz, é sigilosa, inclusive para este, e não vinculante para as partes, sendo sua finalidade exclusiva a de orientá-las na tentativa de composição amigável do conflito. juiz.

$\S 5^{\circ}$ Obtido o acordo, será reduzido a termo e homologado pelo

$\S 6^{\circ} \mathrm{Se}$, por qualquer motivo, a conciliação não produzir resultados e não for adotado outro meio de solução do conflito, o juiz, na mesma audiência, fixará os pontos controvertidos, decidirá as questões processuais pendentes e determinará as provas a serem produzidas, designando audiência de instrução e julgamento, se necessário." (NR)

Art. 44. A Lei $\mathrm{n}^{\circ}$ 5.869, de 1973 - Código de Processo Civil, passa a vigorar acrescida do seguinte art. 331-A:

"Art. 331-A. Em qualquer tempo e grau de jurisdição, poderá o juiz ou tribunal adotar, no que couber, as providências do art. 331."

Art. 45. Os Tribunais de Justiça dos Estados, no prazo de 180 (cento e oitenta) dias, expedirão as normas indispensáveis à efetivação do disposto nesta Lei.

Art. 46. O termo de mediação, de qualquer natureza, frustrado ou não o acordo, conterá expressamente a fixação dos honorários do mediador, ou do co-mediador, se for 0 caso. 
Parágrafo único. Fixando as partes os honorários do mediador, no termo de mediação, este constituirá título executivo extrajudicial; não havendo tal estipulação, o mediador requererá ao Tribunal de Justiça que seria competente para julgar, originariamente, a causa, que os fixe por sentença.

Art. 47. Esta Lei entra em vigor 4 (quatro) meses após a data de sua publicação.

Senado Federal, em 12 de julho de 2006.

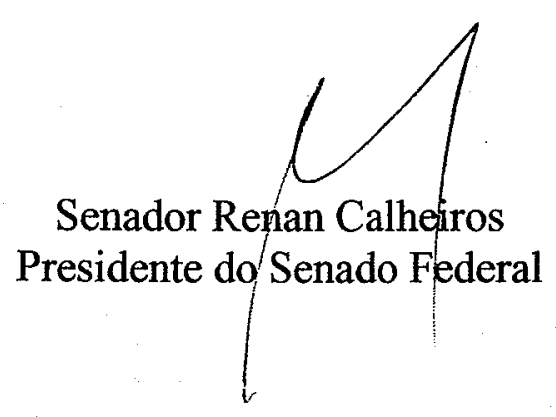




\section{PARECER N ${ }^{\circ}$, DE 2006}

Da COMISSÃO DE CONSTITUIÇÃO, JUSTIÇA E CIDADANIA, sobre o Projeto de Lei da Câmara $n^{\circ}$ 94, de 2002 ( $\mathrm{n}^{\circ} 4.827$, de 1998, na Casa de origem), que institucionaliza e disciplina a mediação, como método de prevenção e solução consensual de conflitos.

\section{RELATOR: Senador PEDRO SIMON}

\section{I - RELATÓRIO}

Vem ao exame desta Comissão o Projeto de Lei da Câmara ${ }^{\circ}$ 94, de $\$ 002$ ( $\mathrm{n}^{\circ} 4.827$, de 1998, na Casa de origem), de autoria da Deputada Zulaiê Cobra, que institucionaliza e disciplina a mediação, como método de prevenção e solução consensual de conflitos.

A proposição traz a disciplina jurídica da mediação - judicial ou extrajudicial -, definida como atividade técnica exercida por terceira pessoa, que, escolhida ou aceita pelas partes interessadas, as escuta e orienta com o propósito de lhes permitir que, de modo consensual, previnam ou solucionem conflitos.

O projeto contempla a possibilidade de mediação em toda matéria que a lei civil ou penal admita conciliação, reconciliação ou transação, apontando como mediadores, tanto pessoas físicas quanto pessoas jurídicas, que, nos termos de seu objeto social, se dediquem ao exercício da mediação.

Na Câmara dos Deputados, o projeto foi aprovado pela Comissão de Constituição, Justiça e Redação, não tendo sido interposto o recurso a que alude o inciso I, do $\S 2^{\circ}$ do art. 58 da Constituição Federal, sendo então remetido a esta Câmara Alta para revisão, a teor do que dispõe o art. 65 da Constituição da República.

Nesta Casa, a proposição não recebeu emendas. Entretanto, o Senador Eduardo Suplicy, apresentou na última reunião da CCJ (08/03/2006) Voto em Separado, que também constituirá objeto desta análise.

\section{II - ANÁLISE}

Os requisitos formais e materiais de constitucionalidade são atendidos pelo Projeto de Lei da Câmara $\mathrm{n}^{\circ}$ 94, de 2002, merecendo registro que é competência privativa da União legislar sobre direito processual (CF/88, art. 22, inciso I). Da mesma forma, no que concerne à juridicidade, a proposta se revela isenta da necessidade de reparos.

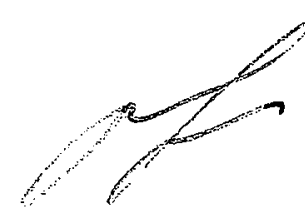


Quanto ao mérito, porém, cremos que o avanço trazido pela proposição afigura-se tímido. Cabe salientar que, hoje, se vive no Brasil momento especialmente favorável às iniciativas que buscam desafogar o Poder Judiciário, trazendo à luz mecanismos modernos de solução alternativa de conflitos.

Não podemos nos furtar à menção do novíssimo inciso LXXVIII do art. $5^{\circ}$ da Constituição Federal (introduzido pela Emenda Constitucional ${ }^{\circ} 45$, de 2004 - Reforma do Judiciário), que estatui que "a todos, no âmbito judicial $e$ administrativo, são assegurados a razoável duração do processo e os meios que garantam a celeridade de sua tramitação". Ora, essa norma programática é que nos anima a perseguir avanços ainda maiores na legislação acerca da mediação.

Nesse sentido, mantivemos intenso diálogo com instituições públicas e representantes da sociedade civil, e recebemos diversas sugestões de aperfeiçoamento da proposta ora relatada, merecendo destaque as sugestões do Conselho Regional de Administração do Rio Grande do Sul, da Secretaria de Reforma do Judiciário do Ministério da Justiça, do Grupo de Pesquisa e Trabalho em Arbitragem, Mediação e Negociação da Universidade de Brasília, do Instituto de Mediação e Arbitragem do Brasil e do Centro de Administração de Conflitos.

As sugestões diferem parcialmente do projeto aprovado pela Câmara dos Deputados, justamente por avançar na disciplina jurídica da mediação, classificando-a em judicial ou extrajudicial e prévia ou incidental. Outrossim, as sugestões contemplam a formação e seleção dos mediadores, trazendo linhas gerais sobre o Registro de Mediadores, que dará aos interessados - e à sociedade, em última análise - $\mathbf{a}$ indispensável segurança para eleger mediadores, com a garantia de que a pessoa ou instituição escolhida goza de reputação ilibada e vasta experiência na atividade.

Como fruto dessa interação, apresentamos substitutivo, que entendemos disciplinar de forma mais abrangente o instituto da mediação, avançando em alguns pontos que o projeto original aprovado pela Câmara dos Deputados não contemplava, mas sem atentar contra o seu espírito, ressalva feita à mediação penal, que não concordamos deva integrar o texto.

Especificamente quanto à mediação em matéria penal, deve ser feito o registro de que vige nesta seara o princípio da obrigatoriedade da ação penal, que, embora sofra temperamentos, merece um detalhamento incompatível com o texto aprovado pela Câmara dos Deputados. Em verdade, o membro do Ministério Público, que é o dominus litis da ação penal pública, dispõe de "discricionariedade vinculada" quanto à transação penal ou à suspensão condicional do processo, de modo que, para o seu efetivo exercício, é indispensável que a lei traga de forma minuciosa as suas hipóteses de cabimento. 
Nosso substitutivo é estruturado em seis capítulos: I - modalidades de mediação; II - dos mediadores; III - do registro dos mediadores e da fiscalização e controle da atividade de mediação; IV - da mediação prévia; V - da mediação incidental; e VI - disposições finais.

No Capítulo I, definimos a atividade de mediação, e estabelecemos suas modalidades em prévia ou incidental e judicial ou extrajudicial (art. $3^{\circ}$ ), assentando que ela será sempre sigilosa, salvo convenção das partes (art. $6^{\circ}$ ) e que o termo de transação lavrado pelo mediador e assinado por ele e pelos interessados poderá ser homologado pelo juiz e consistirá em título executivo judicial. (art. $7^{\circ}$ ).

No Capítulo II, trouxemos a disciplina jurídica dos mediadores, assentando quem pode ser mediador judicial (art. 10) e extrajudicial (art. 11) e comediador (art. 15), outorgando atribuições à Ordem dos Advogados do Brasil, aos Tribunais de Justiça dos Estados e às instituições especializadas previamente credenciadas pelos Tribunais de Justiça para treinar e selecionar candidatos à função de mediador (art. 14).

Este, sem dúvida, é ponto sensível para o sucesso da mediação, pois é fundamental a habilidade pessoal do mediador para apaziguar os ânimos e buscar uma solução consensuada do conflito.

O Capítulo II, outrossim, equipara os mediadores, quando no exercício de suas atribuições, aos funcionários públicos para fins penais (art. 12, in fine), e aos auxiliares da justiça, para todos os fins (art. 12), impondo-lhes os deveres de imparcialidade, independência, aptidão, diligência e confidencialidade (art. 13).

No Capítulo III, tratamos do Registro de Mediadores, mantido pelos Tribunais de Justiça (art. 16), a quem caberá normatizar o processo de inscrição dos mediadores que atuarão no âmbito de sua jurisdição (art. $16, \S 1^{\circ}$ ). Ademais, inserimos disposição que impõe aos Tribunais de Justiça a sistematização dos dados dos mediadores e a sua publicação para fins estatísticos (art. 16, $\S 4^{\circ}$ ).

Neste ponto, optamos por tornar a inscrição no Registro de Mediadores obrigatória para o exercício da atividade de mediação, seja judicial ou extrajudicial. Tal fato se deve à necessidade de se ter o efetivo controle do trabalho dos mediadores, de modo a assegurar aos que optarem pela prevenção ou solução de seus conflitos pela mediação, que o terceiro que escolherem para conduzir os trabalhos gozará dos atributos que a lei exige. Tal providência será útil, ainda, para que haja rigoroso controle estatístico.

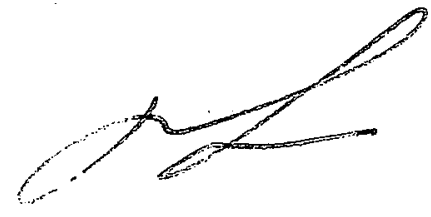


Além disso, com o controle do Registro de Mediadores pelo Tribunal de Justiça do Estado, será possível punir efetivamente os mediadores que apresentarem desvios de conduta e bani-los do exercício da atividade de mediação, impedindo que maus mediadores inviabilizem a incorporação da mediação na cultura dos brasileiros.

Ademais, está descrita a forma de fiscalização e controle da atividade de mediação. Aqui, arrolamos hipóteses de impedimento dos mediadores e condutas passíveis de censura (arts. 20 a 24), trazendo linhas gerais sobre o processo administrativo a que se submeterão os mediadores (art. 25). Cabe registrar a disciplina especial trazida para os mediadores judiciais, que submeterse-ão ao controle efetuado pela Ordem dos Advogados do Brasil (art. 18).

Outrossim, no Capítulo III estão enumeradas as hipóteses de exclusão do Registro de Mediadores, e a cláusula de vedação de recadastramento do mediador excluído por conduta inadequada, em qualquer local do território nacional (art. $24, \S 2^{\circ}$ ).

No Capítulo IV, acolhendo quase integralmente as propostas da Secretaria de Reforma do Judiciário do Ministério da Justiça, do Conselho Regional de Administração do Rio Grande do Sul e do Grupo de Pesquisa e Trabalho em Arbitragem, Mediação e Negociação da Universidade de Brasília, disciplinamos a mediação prévia.

No Capítulo V, contribuiu a solidez dos argumentos esposados nas sugestões da Secretaria de Reforma do Judiciário do Ministério da Justiça e do Conselho Regional de Administração do Rio Grande do Sul, no sentido de tornar obrigatória a tentativa de mediação incidental. Neste sentido, a obrigatoriedade da mediação incidental pode ter o condão de estimular a auto-composição e desafogar as varas de primeira instância.

Por fim, o Capítulo VI traz disposições finais, de caráter geral, estatuindo que a atividade do mediador será sempre remunerada e estabelecendo o prazo de 180 dias para os Tribunais de Justiça expedirem as normas regulamentadoras que viabilizem o início das atividades.

Como já foi dito, foi apresentado, na última reunião desta Comissão, relatório substitutivo de autoria do ilustre senador Eduardo Suplicy, espelhando posicionamento do Ministério da Justiça e, conforme acordado com o nobre colega, reapresento meu parecer com nova redação contemplando e acatando em parte as propostas ora apresentadas.

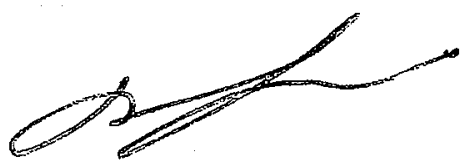


III - VOTO

Com as considerações precedentes de que ressaltam a constitucionalidade, juridicidade, oportunidade e conveniência da proposta, votamos pela aprovação do Projeto de Lei da Câmara $n^{\circ}$ 94, de $2002\left(n^{\circ} 4.827\right.$, de 1998, na origem), na forma do substitutivo a seguir:

$$
\begin{aligned}
\text { EMENDA No } & \mathbb{1} \text { - CCJ (SUBSTITUTIVO) } \\
& \text { Institucionaliza e disciplina a mediação, } \\
& \text { como método de prevenção e solução } \\
& \text { consensual de conflitos na esfera civil, e dá } \\
& \text { outras providências. }
\end{aligned}
$$

\section{O CONGRESSO NACIONAL decreta:}

\section{CAPÍTULO I DISPOSIÇÕES GERAIS}

conflitos de natureza civil.

Art. $1^{\circ}$ Esta Lei institui e disciplina a mediação paraprocessual nos

Art. $2^{\circ}$ Para fins desta Lei, mediação é a atividade técnica exercida por terceiro imparcial que, escolhido ou aceito pelas partes interessadas, as escuta, orienta e estimula, sem apresentar soluções, com o propósito de lhes permitir a prevenção ou solução de conflitos de modo consensual.

Art. $3^{0}$ A mediação paraprocessual será prévia ou incidental, em relação ao momento de sua instauração, e judicial ou extrajudicial, conforme a qualidade dos mediadores.

Art. $4^{0}$ É lícita a mediação em toda matéria que admita conciliação, reconciliação, transação ou acordo de outra ordem.

Art. $5^{\circ}$ A mediação poderá versar sobre todo o conflito ou parte dele.

Art. $6^{0}$ A mediação será sigilosa, salvo estipulação expressa em contrário pelas partes, observando-se, em qualquer hipótese, o disposto nos arts. 13 e 14.

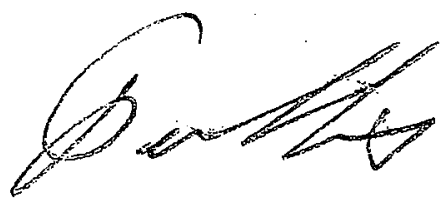


Art. $7^{\circ} \mathrm{O}$ acordo resultante da mediação se denominará termo de mediação e deverá ser subscrito pelo mediador, judicial ou extrajudicial, pelas partes e advogados, constituindo-se título executivo extrajudicial.

Parágrafo único. A mediação prévia, desde que requerida, será reduzida a termo e homologada por sentença, independentemente de processo.

Art. $8^{\circ}$ A pedido de qualquer um dos interessados, o termo de mediação obtido na mediação prévia ou incidental, poderá ser homologado pelo juiz, caso em que terá eficácia de título executivo judicial.

\section{CAPÍTULO II DOS MEDIADORES}

Art. $9^{\circ}$ Pode ser mediador qualquer pessoa capaz, de conduta ilibada e com formação técnica ou experiência prática adequada à natureza do conflito, nos termos desta Lei.

Art. $1^{\circ}$ Os mediadores serão judiciais ou extrajudiciais.

Art. 11. São mediadores judiciais os advogados com pelo menos três anos de efetivo exercício de atividades jurídicas, capacitados, selecionados e inscritos no Registro de Mediadores, na forma desta Lei.

Art. 12. São mediadores extrajudiciais aqueles independentes, selecionados e inscritos no respectivo Registro de Mediadores, na forma desta Lei.

Art. 13. Na mediação paraprocessual, os mediadores judiciais ou extrajudiciais e os co-mediadores são considerados auxiliares da justiça, e, quando no exercício de suas funções, e em razão delas, são equiparados aos funcionários públicos, para os efeitos da lei penal.

Art. 14. No desempenho de suas funções, o mediador deverá proceder com imparcialidade, independência, aptidão, diligência e confidencialidade, salvo, no último caso, por expressa convenção das partes.

Art. 15. Caberá, em conjunto, à Ordem dos Advogados do Brasil, aos Tribunais de Justiça dos Estados e às pessoas jurídicas especializadas em mediação, nos termos de seu estatuto social, desde que, no último caso, devidamente autorizadas pelo Tribunal de Justiça do Estado em que estejam localizadas, a formação e seleção de mediadores, para o que serão implantados cursos apropriados, fixando-se os critérios de aprovação, com a publicação do regulamento respectivo.

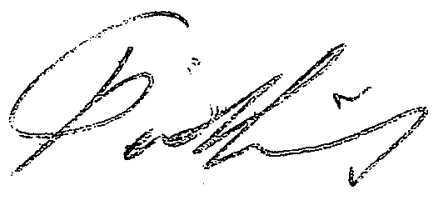


Art. 16. É lícita a co-mediação quando, pela natureza ou pela complexidade do conflito, for recomendável a atuação conjunta do mediador com outro profissional especializado na área do conhecimento subjacente ao litígio.

$\S 1^{\circ}$ A co-mediação será obrigatória nas controvérsias submetidas à mediação que versem sobre o estado da pessoa e Direito de Família, devendo dela necessariamente participar psiquiatra, psicólogo ou assistente social.

$\S 2^{\circ}$ A co-mediação, quando não for obrigatória, poderá ser requerida por qualquer dos interessados ou pelo mediador.

\section{CAPÍTULO III \\ DO REGISTRO DE MEDIADORES E DA FISCALIZAÇÃO E CONTROLE DA ATIVIDADE DE MEDIAÇÃO}

Art. 17. O Tribunal de Justiça local manterá Registro de Mediadores, contendo relação atualizada de todos os mediadores habilitados a atuar prévia ou incidentalmente no âmbito do Estado.

$\S 1^{\circ}$ Os Tribunais de Justiça expedirão normas regulamentando o processo de inscrição no Registro de Mediadores.

$\S 2^{\circ} \mathrm{A}$ inscrição no Registro de Mediadores será requerida ao Tribunal de Justiça local, na forma das normas expedidas para este fim, pelos que tiverem cumprido satisfatoriamente os requisitos do art. 15 desta Lei.

$\S 3^{\circ}$ Do registro de mediadores constarão todos os dados relevantes referentes à atuação do mediador, segundo os critérios fixados pelo Tribunal de Justiça local.

$\S 4^{\circ}$ Os dados colhidos na forma do parágrafo anterior serão classificados sistematicamente pelo Tribunal de Justiça, que os publicará anualmente para fins estatísticos.

Art. 18. Na mediação extrajudicial, a fiscalização das atividades dos mediadores e co-mediadores competirá sempre ao Tribunal de Justiça do Estado, na forma das normas específicas expedidas para este fim.

Art. 19. Na mediação judicial, a fiscalização e controle da atuação do mediador será feita pela Ordem dos Advogados do Brasil, por intermédio de suas seccionais; a atuação do co-mediador será fiscalizada e controlada pelo Tribunal de Justiça.

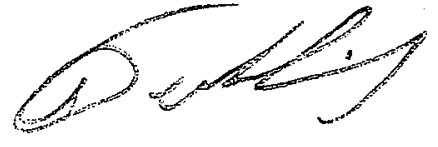


Art. 20. Se a mediação for incidental, a fiscalização também caberá ao juiz da causa, que, verificando a atuação inadequada do mediador ou do comediador, poderá afastá-lo de suas atividades relacionadas ao processo, e, em caso de urgência, tomar depoimentos e colher provas, dando notícia, conforme o caso, à Ordem dos Advogados do Brasil ou ao Tribunal de Justiça, para as medidas cabíveis.

Art. 21. Aplicam-se aos mediadores e co-mediadores os impedimentos previstos nos artigos 134 e 135 do Código de Processo Civil.

$\S 1^{\circ}$ No caso de impedimento, o mediador devolverá os autos ao distribuidor, que designará novo mediador; se a causa de impedimento for apurada quando já iniciado o procedimento de mediação, o mediador interromperá sua atividade, lavrando termo com o relatório do ocorrido e solicitará designação de novo mediador ou co-mediador.

$\S 2^{\circ} \mathrm{O}$ referido relatório conterá:

a) nomes e dados pessoais das partes envolvidas;

b) indicação da causa de impedimento ou suspeição;

c) razões e provas existentes pertinentes do impedimento ou suspeição.

Art. 22. No caso de impossibilidade temporária do exercício da função, o mediador informará o fato ao Tribunal de Justiça, para que, durante o período em que subsistir a impossibilidade, não lhe sejam feitas novas distribuições.

Art. 23. O mediador fica absolutamente impedido de prestar serviços profissionais a qualquer das partes, em matéria correlata à mediação; o impedimento terá o prazo de dois anos, contados do término da mediação, quando se tratar de outras matérias.

Art. 24. Considera-se conduta inadequada do mediador ou do comediador a sugestão ou recomendação acerca do mérito ou quanto aos termos da resolução do conflito, assessoramento, inclusive legal, ou aconselhamento, bem como qualquer forma explícita ou implícita de coerção para a obtenção de acordo.

Art. 25. Será excluído do Registro de Mediadores aquele que: justificação;

I - assim o solicitar ao Tribunal de Justiça, independentemente de II - agir com dolo ou culpa na condução da mediação sob sua responsabilidade;

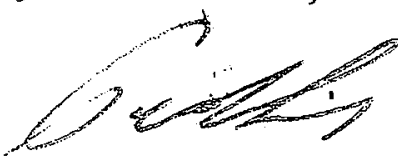


ou sob suspeição;

III - violar os princípios de confidencialidade e imparcialidade;

IV - funcionar em procedimento de mediação mesmo sendo impedido

$\mathrm{V}$ - sofrer, em procedimento administrativo realizado pela Ordem dos Advogados do Brasil, pena de exclusão do Registro de Mediadores;

VI - for condenado, em sentença criminal transitada em julgado.

$\S 1^{\circ}$ Os Tribunais de Justiça dos Estados, em cooperação, consolidarão mensalmente relação nacional dos excluídos do Registro de Mediadores.

$\S 2^{\circ}$ Salvo no caso do inciso I, aquele que for excluído do Registro de Mediadores não poderá, em hipótese alguma, solicitar nova inscrição em qualquer parte do território nacional ou atuar como co-mediador.

Art. 26. O processo administrativo para averiguação de conduta inadequada do mediador poderá ser iniciado de ofício ou mediante representação e obedecerá ao procedimento estabelecido pelo Tribunal de Justiça local.

Art. 27. O processo administrativo conduzido pela Ordem dos Advogados do Brasil obedecerá ao procedimento previsto no Título III da Lei $\mathrm{n}^{\circ}$ 8.906, de 1994, podendo ser aplicada desde a pena de advertência até a exclusão do Registro de Mediadores.

Parágrafo único. O processo administrativo a que se refere o caput será concluído em, no máximo, noventa dias, e suas conclusões enviadas ao Tribunal de Justiça para anotação no registro do mediador ou seu cancelamento, conforme o caso.

Art. 28. O co-mediador afastado de suas atividades nos termos do art. 19, desde que sua conduta inadequada seja comprovada em regular procedimento administrativo, fica impedido de atuar em novas mediações pelo prazo de dois anos.

\section{CAPÍTULO IV DA MEDIAÇÃO PRÉVIA}

Art. 29. A mediação prévia pode ser judicial ou extrajudicial.

Parágrafo único. O requerimento de mediação prévia interrompe a prescrição e deverá ser concluído no prazo máximo de 90 dias.

Art. 30. O interessado poderá optar pela mediação prévia judicial. Neste caso, o requerimento adotará formulário padronizado, subscrito por ele ou

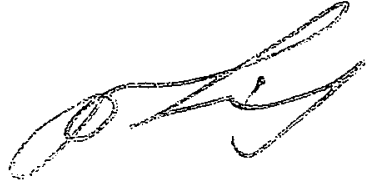


por seu advogado, sendo, neste caso, indispensável à juntada do instrumento de mandato. imediatamente.

$\S 1^{\circ}$ Distribuído ao mediador, o requerimento ser-lhe-á encaminhado

$\S 2^{\circ}$ Recebido o requerimento, o mediador designará dia, hora e local onde realizará a sessão de mediação, dando ciência aos interessados por qualquer meio eficaz e idôneo de comunicação.

$\S 3^{\circ}$ A cientificação ao requerido conterá a recomendação de que deverá comparecer à sessão acompanhado de advogado, quando a presença deste for indispensável. Neste caso, não tendo o requerido constituído advogado, o mediador solicitará à Defensoria Pública ou, na falta desta, à Ordem dos Advogados do Brasil a designação de advogado dativo. Na impossibilidade de pronto atendimento à solicitação, o mediador imediatamente remarcará a sessão, deixando os interessados já cientificados da nova data e da indispensabilidade dos advogados.

$\S 4^{\circ}$ Os interessados, de comum acordo, poderão escolher outro mediador, judicial ou extrajudicial.

$\S 5^{\circ}$ Não sendo encontrado o requerido, ou não comparecendo qualquer das partes, estará frustrada a mediação.

Art. 31. Obtido ou não o acordo, o mediador lavrará o termo de mediação, descrevendo detalhadamente todas as cláusulas do mesmo ou consignando a sua impossibilidade.

Parágrafo único. $\mathrm{O}$ mediador devolverá o requerimento ao distribuidor, acompanhado do termo de mediação, para as devidas anotações.

Art. 32. A mediação prévia extrajudicial, a critério dos interessados, ficará a cargo de mediador independente ou daquele ligado à instituição especializada em mediação.

Art. 33. Em razão da natureza e complexidade do conflito, o mediador judicial ou extrajudicial, a seu critério ou a pedido de qualquer das partes, prestará seus serviços em regime de co-mediação com profissional especializado em outra área que guarde afinidade com a natureza do conflito.
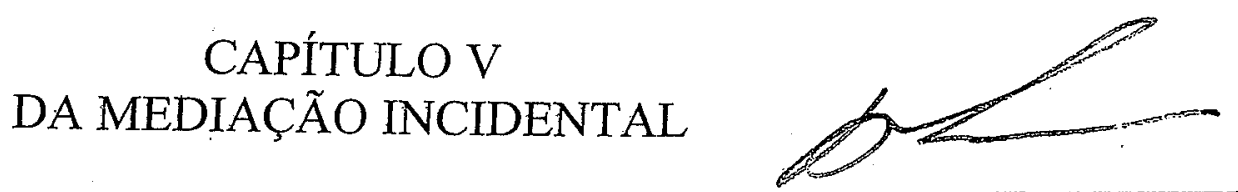
Art. 34. A mediação incidental será obrigatória no processo de conhecimento, salvo nos seguintes casos:

I - na ação de interdição;

II - quando for autora ou ré pessoa de direito público e a controvérsia versar sobre direitos indisponíveis;

III -- na falência, na recuperação judicial e na insolvência civil;

IV - no inventário e no arrolamento; bem imóvel;

$\mathrm{V}$ - nas ações de imissão de posse, reivindicatória e de usucapião de

VI - na ação de retificação de registro público; pela arbitragem;

VII - quando o autor optar pelo procedimento do juizado especial ou

VIII - na ação cautelar;

IX - quando na mediação prévia, realizada na forma da seção anterior, tiver ocorrido sem acordo nos cento e oitenta dias anteriores ao ajuizamento da ação.

Parágrafo único. A mediação deverá ser realizada no prazo máximo de 90 dias e, não sendo alcançado o acordo, dar-se-á continuidade ao processo, .

Art. 35. Nos casos de mediação incidental, a distribuição da petição inicial ao juízo interrompe a prescrição, induz litispendência e produz os demais efeitos previstos no art. 263 do Código de Processo Civil. respectiva decisão.

$\S 1^{\circ}$ Havendo pedido de liminar, a mediação terá curso após a

$\S 2^{\circ}$ A interposição de recurso contra a decisão liminar não prejudica o processo de mediação.

Art. 36. A designação inicial será de um mediador, judicial ou extrajudicial, a quem será remetida cópia dos autos do processo judicial.

Parágrafo único. As partes, de comum acordo, poderão escolher outro mediador, judicial ou extrajudicial.

Art. 37. Cabe ao mediador intimar as partes por qualquer meio eficaz e idôneo de comunicação, designando dia, hora e local para seu comparecimento.

$\S 1^{\circ}$ A intimação deverá conter a recomendação de que as partes deverão se fazer acompanhar de advogados, quando indispensável à assistência judiciária.

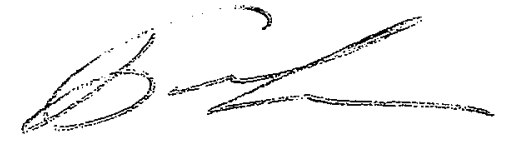


$\S 2^{\circ}$ Se o requerido não tiver sido citado no processo judicial, a intimação para a sessão de mediação constitui-lo-á em mora, tornando prevento o juízo, induzindo litispendência, fazendo litigiosa a coisa e interrompendo a prescrição.

$\S 3^{\circ}$ Se qualquer das partes não tiver advogado constituído nos autos do processo judicial, o mediador procederá de acordo com o disposto na parte final do $\S 3^{\circ}$ do art. 30 .

$\S 4^{\circ}$ Não sendo encontrado o requerido, ou não comparecendo qualquer das partes, estará frustrada a mediação.

Art. 38. Na hipótese de mediação incidental, ainda que haja pedido de liminar, a antecipação das despesas do processo, a que alude o art. 19 do Código de Processo Civil, somente será devida após a retomada do curso do processo, se a mediação não tiver resultado em acordo ou conciliação.

Parágrafo único. O valor pago a títulos de honorários do mediador, na forma do art. 19 do Código de Processo Civil, será abatido das despesas do processo.

Art. 39. Obtido ou frustrado o acordo, o mediador lavrará o termo de mediação descrevendo detalhadamente todas as cláusulas do acordo ou consignando sua impossibilidade.

$\S 1^{\circ} \mathrm{O}$ mediador devolverá a petição inicial ao juiz da causa, acompanhada do termo, para que seja dado prosseguimento ao processo.

$\S 2^{\circ}$ Ao receber a petição inicial acompanhada do termo de transação, o juiz determinará seu imediato arquivamento ou, frustrada a transação, providenciará a retomada do processo judicial.

Art. 40. Havendo acordo, o juiz da causa, após verificar o preenchimento das formalidades legais, homologará o acordo por sentença.

Parágrafo único. Se o acordo for obtido quando o processo judicial estiver em grau de recurso, a homologação do mesmo caberá ao relator.

\section{CAPÍTULO VI DISPOSIÇÕES FINAIS}


Art. 41. A mediação será sempre realizada em local de fácil acesso, com estrutura suficiente para atendimento condigno dos interessados, disponibilizado por entidade pública ou particular para o desenvolvimento das atividades de que trata esta Lei.

Parágrafo único. O Tribunal de Justiça local fixará as condições mínimas a que se refere este artigo.

Art. 42. Os serviços do mediador serão sempre remunerados, nos termos e segundo os critérios fixados pela norma local.

$\S 1^{\circ}$ Nas hipóteses em que for concedido o benefício da assistência judiciária, estará a parte dispensada do recolhimento dos honorários, correndo as despesas às expensas de dotação orçamentária do respectivo Tribunal de Justiça.

Art. 43. O art. 331 e parágrafos da Lei n ${ }^{\circ} 5.869$, de 1973, Código de Processo Civil, passam a vigorar com a seguinte redação:

“Art. 331. Se não se verificar qualquer das hipóteses previstas nas seções precedentes, o juiz designará audiência preliminar, a realizar-se no prazo máximo de trinta dias, para qual serão as partes intimadas a comparecer, podendo fazer-se representar por procurador ou preposto, com poderes para transigir.

$\S 1^{\circ} \mathrm{Na}$ audiência preliminar, o juiz ouvirá as partes sobre os motivos e fundamentos da demanda e tentará a conciliação, mesmo tendo sido realizada a tentativa de mediação prévia ou incidental.

$\S 2^{\circ}$ A lei local poderá instituir juiz conciliador ou recrutar conciliadores para auxiliarem o juiz da causa na tentativa de solução amigável dos
conflitos.

$\S 3^{\circ}$ Segundo as peculiaridades do caso, outras formas adequadas de solução do conflito poderão ser sugeridas pelo juiz, inclusive a arbitragem, na forma da lei, a mediação e a avaliação neutra de terceiro.

$\S 4^{\circ}$ A avaliação neutra de terceiro, a ser obtida no prazo a ser fixado pelo juiz, é sigilosa, inclusive para este, e não vinculante para as partes, sendo sua

$\S 5^{\circ}$ Obtido o acordo, será reduzido a termo e homologado pelo juiz.

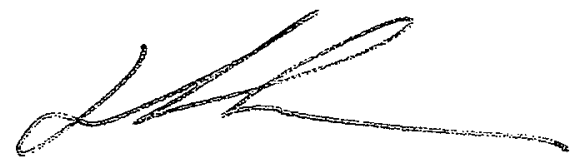


$\S 6^{\circ} \mathrm{Se}$, por qualquer motivo, a conciliação não produzir resultados e não for adotado outro meio de solução do conflito, o juiz, na mesma audiência, fixará os pontos controvertidos, decidirá as questões processuais pendentes e determinará as provas a serem produzidas, designando audiência de instrução e julgamento, se necessário" (NR)

Art. 44. Fica acrescentado à Lei $\mathrm{n}^{\circ}$ 5.869, de 1973, Código de Processo Civil, o art. 331-A, com a seguinte redação:

“Art. 331 - A. Em qualquer tempo e grau de jurisdição, poderá o juiz ou tribunal adotar, no que couber, as providências no artigo anterior".

Art. 45. Os Tribunais de Justiça dos Estados, no prazo de 180 dias, expedirão as normas indispensáveis à efetivação do disposto nesta Lei.

Art. 46. O termo de mediação, de qualquer natureza, frustrado ou não o acordo, conterá expressamente a fixação dos honorários do mediador, ou do co-
mediador, se for o caso.

Parágrafo único. Fixando as partes os honorários do mediador, no termo de mediação, este constituirá título executivo extrajudicial; não havendo tal estipulação, o mediador requererá ao Tribunal de Justiça que seria competente para julgar, originariamente, a causa, que os fixe por sentença.

Art. 47. Esta Lei entra em vigor na data de sua publicação.

Sala da Comissão, 21 de jumho de 2006.

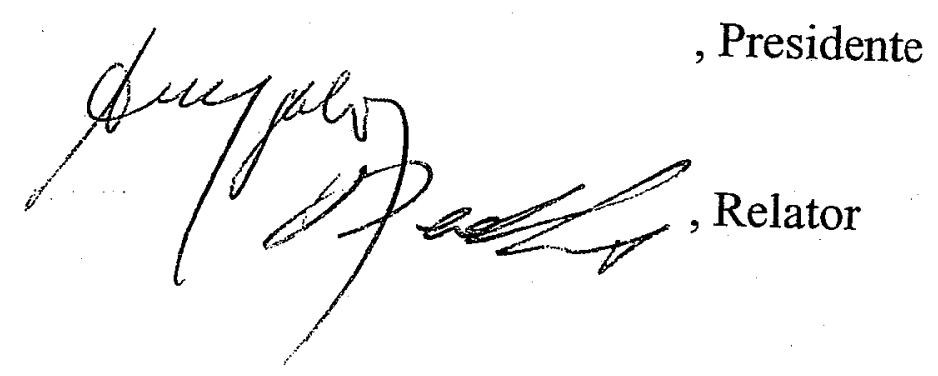




\section{Texto integral de Proposições}

\section{EMENDA No 04}

(ao PLC no 94 de 2002)

Dê-se ao Art. 47 do PLC no 94, de 2002 a seguinte redação:

"Art. 47. Esta Lei entra em vigor quatro meses após a data de sua publicação."

\section{JUSTIFICATIVA}

Para que as partes comecem a fazer uso da mediação, nos termos previstos no presente projeto, é essencial que os Tribunais primeiramente realizem os procedimentos necessários para o cadastro e para a regulamentação dos cadastros de mediadores.

Por isso é necessário estabelecer um prazo de vacância para que os tribunais organizem sua estrutura para cumprir instaurar o procedimento de mediação.

Sala da Comissão, em 21 de junho de 2006.

Senador ALOIZIO MERCADANTE

\section{Fonte:}

Secretaria-Geral da Mesa

Dúvidas, reclamações e informações: $\underline{\text { Secretaria-Geral da Mesa }}$ 


\section{EMENDA No 02}

(ao PLC no 94, de 2002)

Acresça-se, ao art. 17 do Substitutivo do Relator ao PLC no 94, de 2002, § 50 com a seguinte redação:

"Art. 17.

$\S 5^{\circ}$ No caso de atuação de defensor público como mediador, o registro, a fiscalização e o controle da atividade serão realizados pela Defensoria Pública."

\section{JUSTIFICAÇÃO}

A presente emenda visa a atribuir efetiva participação à Defensoria Pública como agente condutor das formas extrajudiciais de solução de litígios, fortalecendo a sua atuação institucional. É importante registrar, nesse particular, que diversos projetos de mediação vêm sendo patrocinados, com sucesso, pelas Defensorias Públicas de diversos estados do País, o que torna a sua participação imprescindível.

Assim, propomos o acolhimento desta emenda com a finalidade de aperfeiçoar o texto do PLC no 94, de 2002.

Sala da Comissão,

\section{Senador JUVÊNCIO DA FONSECA}

\section{Fonte:}

Secretaria-Geral da Mesa

Dúvidas, reclamações e informações: Secretaria-Geral da Mesa 


\section{EMENDA NO 03}

(ao PLC no 94, de 2002)

Dê-se ao art. 30 do Substitutivo do Relator ao PLC no 94, de 2002, a seguinte redação:

"Art. 30. O interessado poderá optar pela mediação prévia judicial, caso em que o requerimento adotará formulário padronizado, subscrito por ele ou por seu defensor público ou advogado, sendo, no último caso, indispensável à juntada do instrumento de mandato.

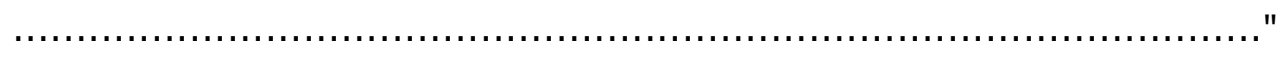

\section{JUSTIFICAÇÃO}

A presente emenda visa a atribuir efetiva participação à Defensoria Pública como agente condutor das formas extrajudiciais de solução de litígios, fortalecendo a sua atuação institucional. É importante registrar, nesse particular, que diversos projetos de mediação vêm sendo patrocinados, com sucesso, pelas Defensorias Públicas de diversos Estados do País, o que torna a sua participação imprescindível.

Assim, propomos o acolhimento desta emenda com a finalidade de aperfeiçoar o texto do PLC no 94, de 2002.

Sala da Comissão,

\section{Senador JUVÊNCIO DA FONSECA}

bd0619h9-200603700

\section{Fonte:}

Secretaria-Geral da Mesa

Dúvidas, reclamações e informações: $\underline{\text { Secretaria-Geral da Mesa }}$ 


\section{EMENDA NO 04}

(ao PLC no 94 de 2002)

Dê-se ao Art. 47 do PLC no 94, de 2002 a seguinte redação:

"Art. 47. Esta Lei entra em vigor quatro meses após a data de sua publicação."

\section{JUSTIFICATIVA}

Para que as partes comecem a fazer uso da mediação, nos termos previstos no presente projeto, é essencial que os Tribunais primeiramente realizem os procedimentos necessários para o cadastro e para a regulamentação dos cadastros de mediadores.

Por isso é necessário estabelecer um prazo de vacância para que os tribunais organizem sua estrutura para cumprir instaurar o procedimento de mediação.

Sala da Comissão, em 21 de junho de 2006.

Senador ALOIZIO MERCADANTE

Fonte:

Secretaria-Geral da Mesa

Dúvidas, reclamações e informações: $\underline{\text { Secretaria-Geral da Mesa }}$ 


\section{INSTITUTO BRASILEIRO DE DIREITO PROCESSUAL ESCOLA NACIONAL DA MAGISTRATURA VERSÃO CONSENSUADA (17.09.03) PROJETO DE LEI SOBRE}

\section{A MEDIAÇÃO E OUTROS MEIOS DE PACIFICAÇÃO EXPOSIÇÃ̃O DE MOTIVOS}

O presente Projeto de Lei divide-se em duas vertentes: a - a instituição da mediação no processo

civil e b - a introdução de outros mecanismos de pacificação, na audiência preliminar.

A - DA MEDIAÇÃO. 1. O avanço dos mecanismos extrajudiciais de prevenção e solução de controvérsias é inegável no Brasil: a partir da vitoriosa experiência dos Juizados Informais de Conciliação, ficou clara a aspiração social por métodos que pudessem servir para a resolução dos conflitos sociais fora dos meandros do Poder Judiciário, cujos órgãos estão sabidamente sobrecarregados e cuja atuação dificilmente consegue a pacificação das partes.

2. O legislador não ficou insensível ao clamor social: procurou, de um lado, fortalecer a vertente extrajudicial de solução de controvérsias, o que se concretizou com a edição da Lei 9.307/96, que revitalizou a arbitragem; de outra parte, na vertente judicial, reforçou os poderes conciliatórios do juiz, estimulando essa atividade no curso do processo, como se viu com a edição da Lei 8.952/94 que alterou, entre outros, os artigos 125 e 331 do Código de Processo Civil.

3. Mas ainda não era o bastante. A conciliação judicial sofre atualmente uma série considerável de pressões adversas, de modo a tornar limitados seus resultados práticos: as pautas dos juízes estão lotadas, de tal sorte que estes não podem dedicar-se ao trabalho naturalmente lento da mediação; a atividade desenvolvida pelo juiz na conciliação não é reconhecida para efeito de promoção por merecimento; o juiz é voltado para a cultura da solução adjudicada do conflito e não para sua pacificação; as partes mostram a 2 inibição e o receio de avançar posições, que podem posteriormente desfavorecê-las no julgamento da causa. Na realidade, sem maiores estímulos, a práxis forense fez com que a tentativa de conciliação prevista no art. 331 do Código de Processo Civil ficasse reduzida a mera formalidade, o que levou até mesmo a seu recente redimensionamento legislativo, com a nova redação que lhe foi dada.

4 - Estas dificuldades já haviam sido notadas pelo legislador, que procurou mitigá-las quando editou a lei 7.244/84 (que implantou os Juizados Especiais de Pequenas Causas), valorizando o papel dos conciliadores. O sucesso da iniciativa foi notável, consolidando-se a posição dos conciliadores na lei 9.099/95, que hoje disciplina os Juizados Especiais Cíveis e Criminais

5. Paralelamente, a iniciativa da mediação tomou impulso no Brasil. A criação de centros de arbitragem, impulsionados pela Lei 9.307/96, também ocasionou a abertura dessas instituições à mediação, que floresceu em todo o país, cultivada por instituições e entidades 
especializadas em mediação e por mediadores independentes. Embora próximas, por tenderem ambas à auto-composição (e apartando-se, assim, da arbitragem, que é um meio de heterocomposição de controvérsias, em que o juiz privado substitui o juiz togado), conciliação e mediação distinguem-se porque, na primeira, o conciliador, após ouvir os contendores, sugere a solução consensual do litígio, enquanto na segunda o mediador trabalha mais o conflito, fazendo com que os interessados descubram as suas causas, removam-nas e cheguem assim, por si só, à prevenção ou solução da controvérsia.

\section{6 - O presente Projeto de Lei é o resultado da harmonização de duas propostas} legislativas: o Projeto de Lei n. 94, de 2.002, de autoria da Deputada Zulaiê Cobra, aprovado pela Câmara dos Deputados e atualmente na Comissão de Constituição e Justiça do Senado; e o Anteprojeto de Lei do Instituto Brasileiro de Direito Processual e Escola Nacional da Magistratura, apresentado ao Ministro da Justiça Dr. Márcio Thomas Bastos, no mesmo ano. A Deputada Zulaiê Cobra, o Instituto Brasileiro de Direito Processual e a Escola Nacional da Magistratura trabalharam em conjunto, chegando à versão consensuada de um novo Projeto, que recolhe as idéias fundamentais do Projeto e do Anteprojeto acima indicados, tornando mais completo e satisfatório o resultado final. Por iniciativa do Dr. Sérgio Renault, Secretário da Reforma do Judiciário junto ao Ministério da Justiça, o Projeto consensuado foi apresentado e amplamente debatido em audiência pública, aos17/09/03, na presença dos autores dos primitivos Projeto e Anteprojeto e de membros do Poder Judiciário, da Advocacia e das instituições, entidades e pessoas especializadas em mediação. Muitas das sugestões apresentadas foram acolhidas pela comissão conjunta, que as incorporou ao texto final.

7 - Cumpre notar, ainda, que o novo Projeto incorpora princípios e normas do Projeto Zulaiê Cobra, complementando-as com regras mais detalhadas - de modo a dispensar a regulamentação pelo Poder Executivo, sugerida pelo Relator do referido Projeto, Senador Pedro Simon, em face da verificação da ausência de normas específicas; e, de outro lado, ao mesmo tempo em que incentiva a mediação extrajudicial, preservando plenamente a atuação das instituições, entidades e pessoas especializadas, preocupa-se em trazer a mediação para dentro do Poder Judiciário, por intermédio do que denomina de "mediação paraprocessual" (para=ao lado de, elemento acessório ou subsidiário).

8. O Projeto ora apresentado investe em duas modalidades de mediação: a primeira, denominada mediação prévia (que será sempre facultativa), poderá ser extrajudicial ou judicial, incentivando os interessados a buscar o meio consensual da mediação.; a segunda, incidental (e cuja tentativa é obrigatória), terá lugar sempre que for distribuída demanda (excepcionadas as causas arroladas no art. 6o) sem prévia tentativa de mediação, extrajudicial ou judicial, de sorte que, obtido o acordo, não haverá necessidade de intervenção do juiz estatal.

9. A tentativa obrigatória de mediação incidental não fere o disposto no art.5o, inciso XXXV, da Constituição Federal, que dispõe a respeito da inafastabilidade do acesso aos tribunais porque, diversamente do que ocorre com outros diplomas legislativos, ela ocorrerá após o ajuizamento da demanda, com o que se puderam conferir à distribuição desta e à intimação dos litigantes efeitos que, pelo Código de Processo Civil, são próprios da citação (arts. 7o e 9o, §1o); e ainda porque a parte interessada poderá solicitar a retomada do 
processo judicial, decorrido o prazo de 90 (noventa dias) da data do início do procedimento de mediação (art. 10, §3o).

10. Ainda com relação à tentativa obrigatória de mediação, vale outra observação: a facultatividade tem sido sublinhada como um dos princípios fundamentais da mediação. No entanto, também tem sido apontada a necessidade de se operar uma mudança de mentalidade, para que a via consensual seja mais cultivada do que a litigiosa, o que é um dado essencial para o êxito das vias consensuais, que compreendem a mediação. E o que é obrigatório, no projeto, é a tentativa de mediação e não o acordo. Assentado que os chamados meios alternativos de solução das controvérsias, mais do que uma alternativa ao processo, configuram instrumentos complementares, "multi-portas" mais idôneas do que o processo para a pacificação, é preciso estimular a sedimentação de uma cultura que permita seu vicejar. E, para tanto, a tentativa obrigatória parece constituir o único caminho para alimentar a cultura da mediação.

11. Pelo Projeto ora apresentado, os mediadores serão preparados para o serviço que prestarão à sociedade: para tanto, a contribuição dos Tribunais de Justiça, da Ordem dos Advogados do Brasil e das instituições e entidades especializadas em mediação será imprescindível, pois a capacitação e seleção dos mediadores é ponto sensível para o êxito da iniciativa. E o controle de suas atividades será exercido pelo Tribunal, pelo juiz, e pelos órgãos profissionais oficiais. Os interessados em atuar como mediadores serão advogados, com experiência profissional mínima de três anos e deverão submeter-se a curso preparatório, ao término do qual estarão, se aprovados, sujeitos a regras procedimentais adequadas para auxiliar as partes na busca de uma solução consensual para seu litígio. As partes, de comum acordo, poderão escolher como mediador profissional de outra área. A co-mediação também está prevista no Projeto, sendo obrigatória quando se tratar de controvérsias atinentes ao Direito de Família, quando deverá necessariamente atuar um psiquiatra, psicólogo ou assistente social (arts. 11-14).

12. Também a esse propósito, cabe um esclarecimento: na mediação tradicional os mediadores têm sempre preparação multidisciplinar e são originários de diversos campos profissionais. Mas o que tem que se ter em mente é que o projeto trata da mediação trazida para o processo civil e para este voltada, sendo aconselhável que seja ela conduzida por um profissional do direito, especialmente treinado, para que as partes possam chegar a um acordo que se revista das indispensáveis formalidades jurídicas, uma vez que a transação constituirá, sempre, título executivo extrajudicial e poderá, a pedido das partes e uma vez homologada pelo juiz, ter eficácia de título executivo judicial. Por outro lado, cumpre notar que o Projeto permite a escolha, pelos interessados, do mediador, advogado ou não, cuidando também da co-mediação.

13. Naturalmente a atividade de mediação paraprocessual não estará desligada do controle do Poder Judiciário: para tanto, o Tribunal de Justiça de cada Estado da Federação manterá: a) Registro dos mediadores, por categoria profissional; e b) Cadastro das instituições e entidades especializadas em mediação e de mediadores independentes. Este último cadastro não é obrigatório, podendo as referidas entidades e pessoas continuar exercendo suas atividades de mediação independentemente dele; mas o cadastro será necessário para os fins do inciso $\mathrm{X}$ do art. 6o (dispensa da tentativa obrigatória de mediação incidental, se a 
prévia tiver ocorrido, sem resultado, no prazo de 180 dias anteriores ao processo) e do 4 art.11 (escolha de mediador na mediação incidental) $\mathrm{O}$ controle das atividades do mediador será exercido pela $\mathrm{OAB}$ ou por outros órgãos profissionais oficiais, conforme o caso, e, na mediação incidental, também pelo juiz. Verificada a atuação inadequada de qualquer mediador, poderá o juiz estatal afastá-lo de sua atividade, mandando averiguar a conduta indesejável em regular processo administrativo (art. 18) Também estão previstos os casos de exclusão do Registro ou Cadastro de Mediadores (art.19).

14. A atividade do mediador será sempre remunerada, nos termos e segundo os critérios fixados pela norma local. Esta poderá adotar técnicas que permitam abater os honorários do mediador das taxas judiciárias ou que, nos casos de mediação obrigatória incidental, prevejam que o recolhimento das custas só ocorra após a tentativa frustrada de mediação. Seja como for, o Projeto prevê a dispensa de qualquer pagamento no caso de concessão, pelo juiz, do benefício de gratuidade.

15. Saliente-se, ainda, que o Projeto prestigia e reforça a mediação extrajudicial, conferindo ao acordo natureza de título executivo, judicial ou extrajudicial, conforme seja, ou não, levado à homologação do juiz.

16 - Por último, cabe observar que a mediação paraprocessual, operada dentro do Poder Judiciário, é instituto inovador em nosso direito, de modo que se entendeu oportuno, ao menos por ora, excluir do Projeto as Justiças federal e trabalhista, que têm peculiaridades próprias: a federal, onde a remuneração dos serviços do mediador poderia ficar dificultada; a trabalhista, por ter esquemas conciliativos próprios, recentemente aprovados. A avaliação dos resultados que resultarem da implantação das regras propostas pelo Projeto possibilitará, com maior segurança, sua extensão às duas Justiças acima mencionadas, conforme ocorreu, aliás, com os Juizados Especiais, implantados primeiro no plano estadual e, depois, no federal.

\section{B - DA AUDIÊNCIA PRELIMINAR}

17 - A segunda parte do Projeto (art. 24), dando nova redação ao art. 331 e parágrafos do Código de Processo Civil, pretende recuperar e aperfeiçoar a idéia original da reforma, introduzida pela lei n. 8.952/94, que era fundamentalmente a de fazer com que o juiz assumisse a direção efetiva do processo, colocando-se em contato as partes e ouvindo suas razões e os fundamentos da demanda, e assim buscasse a conciliação. A aplicação superficial do dispositivo na prática forense, encampada pela reforma que lhe deu nova redação, desvirtuou o espírito da norma, gerando a cultura da sentença, até porque o trabalho do juiz só é levado em consideração pelos tribunais em razão do número de sentenças prolatadas.

18 - Mas o ativismo do juiz brasileiro não pode se limitar à condução da causa em direção à decisão adjudicada. Deve ele exercer seus poderes por inteiro na gestão do processo, abrangendo a iniciativa para impulsionar outras formas de solução do conflito, com preferência à pacificação das partes pelos meios consensuais.

19 - Para tanto, o Projeto remodela a audiência preliminar, sempre necessária, abrindo ao 
juiz um leque de opções, que configuram as "multi-portas" representadas por uma série de técnicas de solução do conflito, diversas da sentença autoritativa do poder estatal. E para que o juiz se sinta motivado a dedicarse a esse viés, prevê-se expressamente que essa atuação seja reputada de relevante valor social e considerada para efeito de promoção por merecimento.

20 - Assim, na audiência preliminar, não só se oferece ao juiz o incentivo para uma séria e dedicada tentativa de conciliação, como ainda lhe se abre a possibilidade de sugerir às partes o caminho da 5 arbitragem, da mediação e da avaliação neutra de terceiro, vistas como integrantes da própria técnica da justiça e inseridas num amplo quadro de política judiciária.

21 - A avaliação neutra de terceiro, que consiste no acordo entre as partes para a escolha de um operador do direito com experiência no tema específico, leva ao assentamento das questões relevantes e à avaliação acurada do possível desfecho da causa. Desse modo, as partes poderão compreender melhor suas respectivas posições e o provável resultado do processo, se insistirem no litígio. Fica claro, no Projeto, que a avaliação neutra tem como único objetivo o de orientar os litigantes na tentativa de composição amigável do conflito, sendo sigilosa inclusive com relação ao juiz e não vinculante para as partes.

22 - E ainda, como conseqüência natural do necessário conhecimento dos autos pelo juiz, a partir do momento da audiência preliminar, terá ele condições - caso a tentativa de conciliação e a busca de outros meios de solução do conflito não tiverem êxito - de fixar imediatamente os pontos controvertidos, decidir as questões processuais pendentes e determinar as provas a serem produzidas, designando desde logo audiência de instrução e julgamento, se for o caso. O que também representa uma racionalização do trabalho do juiz e um forte impulso à oralidade.

23 - Por último, cabe dizer que o juiz ou tribunal poderão adotar, em qualquer tempo e grau de jurisdição, no que couber, as providências previstas para a audiência preliminar (art.25). Em conclusão, pode-se afirmar que o Projeto ora apresentado é profundamente inovador, voltandose a transformar a cultura do conflito em cultura de pacificação, único caminho a ser perseguido para uma verdadeira reforma da política judiciária em nosso país. E não é de se desprezar o estímulo que a lei poderá representar até em relação à mediação extrajudicial, conferindo-lhe maior visibilidade e transformando-se num instrumento de sensibilização. Aliás, é de todo oportuno notar que o Brasil, após a reunião de Presidentes dos Tribunais de Justiça latino-americanos, realizada em Margarita em 1999, se comprometeu a implementar os instrumentos complementares de prevenção e solução de litígios; e que praticamente todos os países latino-americanos, com exceção do Brasil, já promulgaram leis sobre a mediação.

6

PROJETO DE LEI DE MEDIAÇÃO

PROJETO DE LEI N. , de de 2.003

Institui e disciplina a mediação paraprocessual como mecanismo complementar de prevenção e solução de conflitos no processo civil e dá nova redação ao artigo 331 e parágrafos do Código de Processo Civil - Lei n. 5.869 de 11 de janeiro de1973. 


\section{O CON G R ES S O A C I O N A d e cre t a : CAPÍTULO I MODALIDADES DE MEDIAÇÃO}

Art. $1^{\circ}$. Para os fins desta lei, mediação é a atividade técnica exercida por terceira pessoa que,

escolhida ou aceita pelas partes interessadas, as escuta e as orienta com o propósito de lhes permitir que,

de modo consensual, previnam ou solucionem conflitos.

§. 1o : É lícita a mediação em toda matéria que admita conciliação, reconciliação, transação ou

acordo de outra ordem.

$\S 20$. A mediação poderá versar sobre todo o conflito ou parte dele.

$\S 3^{\circ}$. A mediação paraprocessual será prévia ou incidental.

$\S 4^{\circ}$. A transação, subscrita pelo mediador, pelos transatores e advogados, constitui título executivo extrajudicial.

§50. A pedido dos interessados, a transação, obtida na mediação prévia ou incidental, poderá

ser homologada pelo juiz, caso em que terá eficácia de título executivo judicial.

§6o. Na mediação prévia, a homologação, desde que requerida, será reduzida a termo e homologada por sentença, independentemente de processo.

7

CAPÍTULO II

SEÇÃO I

DA MEDIAÇÃO PRÉVIA

Art.2o . A mediação prévia é sempre facultativa, podendo ser judicial ou extrajudicial.

Art. $3^{\circ}$. O interessado poderá optar pela mediação prévia judicial, devendo, neste caso, o requerimento ser instrumentalizado por meio de formulário padronizado, que será subscrito por ele e seu

advogado.

$\S 1^{\circ}$. A procuração instruirá o requerimento, facultada a exibição de provas pré-constituídas no

curso do procedimento da mediação.

$\S 2^{\circ}$.O requerimento de mediação prévia será distribuído ao mediador e a ele imediatamente encaminhado.

$\S 3^{\circ}$. Recebido o requerimento, o mediador designará dia, hora e local onde realizará a sessão

de mediação, providenciando a comunicação pessoal, facultada a utilização de todos os meios eficazes de

cientificação.

$\S 4^{\circ}$. A comunicação ao requerido conterá, ainda, a advertência de que deverá comparecer à sessão acompanhado de advogado. Não tendo o requerido advogado constituído, o mediador solicitará à

Ordem dos Advogados do Brasil a designação de dativo.

Art. $4^{\circ}$. Levada a efeito a mediação, o mediador tomará por termo a transação, se obtida, ou consignará sua impossibilidade.

Parágrafo único. Obtida ou frustrada a transação, o mediador devolverá ao distribuidor o 
requerimento, acompanhado do termo, para as devidas anotações.

Art. 5o. A mediação prévia extrajudicial, a critério dos interessados, ficará a cargo dos mediadores judiciais ou de instituições e entidades especializadas em mediação ou

mediadores

independentes.

Parágrafo único - Para os fins do inciso X do art. 60 e do $\S 4^{\circ}$ do art. 11 , as instituições e entidades especializadas em mediação e os mediadores independentes deverão solicitar seu cadastro junto

ao Tribunal de Justiça.

\section{SEÇÃO II}

\section{DA MEDIAÇÃO INCIDENTAL}

Art.6o. A tentativa de mediação incidental é obrigatória no processo de conhecimento, salvo

nos seguintes casos:

I - na ação de interdição;

8

II - quando for autora ou ré pessoa de direito público e a controvérsia versar sobre direitos indisponíveis;

III - na falência, na concordata e na insolvência civil;

IV - no inventário e no arrolamento, quando houver incapazes;

V - nas ações de imissão de posse, reivindicatória de bem imóvel e de usucapião de bem imóvel;

VI - na ação de retificação de registro público;

VII - quando o autor optar pelo procedimento do juizado especial ou pela arbitragem;

VIII - na ação cautelar; e

IX - quando a mediação prévia, realizada na forma da Seção anterior, tiver ocorrido, sem resultado, nos 180 (cento e oitenta) dias anteriores ao ajuizamento da ação.

Art 7 -Nos casos de mediação incidental, a distribuição da petição inicial ao juízo e ao mediador interromperá a prescrição, induzirá litispendência e produzirá os efeitos previstos no artigo 593

de Código de Processo Civil.

§1o.Na hipótese de pedido de liminar, o processo será distribuído ao juiz para apreciação, procedendo-se à mediação após a decisão.

§2o. A interposição de agravo contra a decisão liminar não prejudica o procedimento de mediação.

Art. $8^{\circ}$. A petição inicial será remetida pelo juiz distribuidor ao mediador sorteado, observado

o disposto no parágrafo único do art. 11.

Art. $9^{\circ}$. Cabe ao mediador intimar as partes, por qualquer meio eficaz de comunicação, designando dia, hora e local para seu comparecimento, acompanhados dos respectivos advogados.

$\S 1^{\circ}$. A intimação constituirá o requerido em mora, tornando a coisa litigiosa.

§2o. Não sendo encontrado o requerido, ou não comparecendo qualquer das partes, estará frustrada a mediação.

$\S 3^{\circ}$. Comparecendo qualquer das partes sem advogado, o mediador procederá de acordo com 
o disposto na parte final do parágrafo 4o do artigo 3o.

Art.10 .Levada a efeito a mediação, o mediador procederá nos termos do caput do artigo 4o

$\S 1^{\circ}$. Obtida a transação, o mediador devolverá ao distribuidor a petição inicial, acompanhada do termo, para as devidas anotações.

$\S 2^{\circ}$. Frustrada a transação, o mediador remeterá a petição inicial ao juiz, acompanhada do termo, para a retomada do processo judicial.

9

$\S 3^{\circ}$. Decorridos 90 (noventa) dias da data do início da mediação sem que tenha sido encerrado

o respectivo procedimento, com a obtenção ou não da transação, poderá qualquer das partes solicitar a

retomada do processo judicial.

\section{CAPÍTULO III}

\section{DOS MEDIADORES}

Art.11 - Na mediação paraprocessual, judicial ou extrajudicial, os mediadores são auxiliares da justiça.

§10.Os mediadores judiciais serão selecionados entre advogados com pelo menos 3 (três) anos

de efetivo exercício de profissão jurídica.

§2o Na mediação judicial, prévia ou incidental, os mediadores poderão ser escolhidos pelos interessados entre os mediadores e co-mediadores inscritos no Registro de Mediadores (art.15)

§3o. Na mediação extrajudicial prévia, aplica-se aos mediadores o disposto no art.5o e seu parágrafo único.

§4o Na mediação extrajudicial incidental, as partes poderão escolher instituições e entidades

especializadas em mediação ou mediadores independente, desde que inscritos no Cadastro de Mediadores

(art.16).

Art. 12. No desempenho de sua função o mediador deverá proceder com imparcialidade, independência, competência, diligência e confidencialidade, vedada inclusive a prestação de qualquer informação ao juiz.

Parágrafo único. Caberá à Ordem dos Advogados do Brasil, ao Tribunal de Justiça e às instituições e entidades especializadas em mediação, devidamente cadastradas, em conjunto, a formação e seleção de mediadores, para o que serão implantados cursos apropriados, fixando-se os critérios de aprovação, com a publicação do regulamento respectivo.

Art. 13 -A pedido de qualquer das partes, ou a critério do mediador, este prestará seus serviços em regime de co-mediação, com profissional de outra área, devidamente habilitado, nos termos

do $\$ 20$ deste artigo. 
§1o. A co-mediação será obrigatória nas controvérsias que versem sobre Direito de Família, devendo dela sempre participar psiquiatra, psicólogo ou assistente social.

§2o. O Tribunal de Justiça selecionará, como co-mediadores, profissionais indicados por instituições e entidades especializadas em mediação ou por órgãos profissionais oficiais, devidamente capacitados e credenciados.

Art. 14. Quando no exercício de suas funções, e em razão delas, ficam os mediadores equiparados aos funcionários públicos para efeito da legislação penal.

10

Art.15. O Tribunal de Justiça local manterá um Registro de Mediadores, contendo a relação atualizada de todos os mediadores habilitados a atuar no âmbito do Estado, por área profissional.

$\S 1^{\circ}$. Aprovado no curso de formação e seleção, o mediador, com o certificado respectivo, requererá inscrição no Registro de Mediadores no Tribunal de Justiça local.

§2o. Do Registro de Mediadores constarão todos os dados relevantes referentes à atuação

do

mediador, segundo os critérios fixados pelo Tribunal de Justiça local.

§3o. Os dados colhidos na forma do parágrafo anterior serão classificados sistematicamente pelo Tribunal de Justiça que os publicará, pelo menos anualmente, para efeitos estatísticos. Art. 16. O Tribunal de Justiça também manterá um Cadastro de instituições e entidades especializadas em mediação e de mediadores independentes, para fins do disposto no inciso $\mathrm{X}$ do art. $60 \mathrm{e}$ no $\$ 40$ do art. 11.

Art. 17. A mediação será sempre realizada em local de fácil acesso, com estrutura suficiente para atendimento condigno dos interessados, disponibilizado por entidade pública ou particular para o desenvolvimento das atividades de que trata esta Lei.

Parágrafo único. O Tribunal de Justiça fixará, no prazo máximo de 60 (sessenta) dias após a promulgação desta Lei, as condições mínimas a que se refere este artigo.

Art.18. A fiscalização das atividades dos mediadores competirá à Ordem dos Advogados do Brasil, através de suas secções e subsecções, ou aos órgãos profissionais oficiais, conforme o caso.

§1o - Na mediação incidental, a fiscalização também caberá ao juiz.

§2o O magistrado, verificando atuação inadequada do mediador, poderá afastá-lo de suas atividades no processo, informando a Ordem dos Advogados do Brasil ou, em se tratando de profissional

de outra área, o órgão competente, para instauração do respectivo processo administrativo. §3o.O processo administrativo para averiguação de conduta inadequada do mediador advogado, instaurado de ofício ou mediante representação, seguirá o procedimento previsto no Título III

da Lei 8.906/94, podendo a Ordem dos Advogados do Brasil aplicar desde a pena de advertência até a de exclusão do Registro de Mediadores, tudo sem prejuízo de, verificada também infração ética, promover a entidade as medidas de que trata a referida Lei.

Art. 19. Será excluído do Registro ou Cadastro de Mediadores aquele que: 
I - assim o solicitar ao Tribunal de Justiça, independentemente de justificação;

II - agir com dolo ou culpa na condução da mediação sob sua responsabilidade;

III - violar os princípios de confidencialidade e neutralidade;

IV - funcionar em procedimento de mediação mesmo sendo impedido;

11

Parágrafo único. Os casos previstos nos incisos II a IV serão apurados em regular processo administrativo, nos termos dos $\S 20$ e $\$ 30$ do art. 18 desta Lei, não podendo o mediador excluído ser

reinscrito nos Registros ou Cadastros de Mediadores, em todo o território nacional.

Art. 20 - Não será admitida a atuação do mediador nos termos do artigo 134 do Código de Processo Civil.

Parágrafo único.No caso de impedimento, o mediador devolverá os autos ao distribuidor, que

sorteará novo mediador; se a causa de impedimento for apurada quando já iniciado o

procedimento de

mediação, o mediador interromperá sua atividade, lavrando ata com o relatório do ocorrido

e solicitará

sorteio de novo mediador.

Art.21. No caso de impossibilidade temporária do exercício da função, o mediador informará

o fato ao Tribunal de Justiça para que, durante o período em que perdurar a

impossibilidade, não haja

novas distribuições.

Art. 22. O mediador fica impedido, pelo prazo de 2 (dois) anos, contados a partir do término

da mediação, de prestar serviços profissionais a qualquer das partes.

Art. 23. Os serviços do mediador serão sempre remunerados, nos termos e segundo os critérios fixados pela norma local.

$\S 1$ o. Nas hipóteses em que for concedido o benefício da gratuidade estará a parte dispensada

do recolhimento dos honorários.

$\S 20$. Havendo pedido de concessão de gratuidade, o distribuidor remeterá os autos ao juiz competente para decisão.

Art. 24. O art. 331 e parágrafos do Código de Processo Civil - Lei n. 5.869, de 11 de janeiro de 1.973, passam a vigorar com a seguinte redação:

"Art. 331. Se não se verificar qualquer das hipóteses previstas nas seções precedentes, o juiz

designará audiência preliminar, a realizar-se no prazo máximo de 30 (trinta) dias, para a qual serão as

partes intimadas a comparecer, podendo fazer-se representar por procurador ou preposto, com poderes

para transigir.

$\S 1$. Na audiência preliminar, o juiz ouvirá as partes sobre os motivos e fundamentos da demanda e tentará a conciliação, mesmo tendo sido já realizada a mediação prévia ou incidental.

§2o. A lei local poderá instituir juiz conciliador ou recrutar conciliadores para auxiliarem o juiz da causa na tentativa de solução amigável dos conflitos. 
§3o. Segundo as peculiaridades do caso, outras formas adequadas de solução do conflito poderão ser sugeridas pelo juiz, inclusive a arbitragem, na forma da lei, a mediação e a avaliação neutra

de terceiro.

§4o. A avaliação neutra de terceiro, a ser obtida no prazo a ser fixado pelo juiz, é sigilosa, inclusive para este, e não vinculante para as partes, sendo sua finalidade exclusiva a de orientá-las na tentativa de composição amigável do conflito.

12

§5o. O juiz deverá buscar, prioritariamente, a pacificação das partes, ao invés da solução adjudicada do conflito, sendo sua dedicada atuação nesse sentido reputada de relevante valor social e considerada para efeito de promoção por merecimento.

§6o. Obtido o acordo, será reduzido a termo e homologado pelo juiz.

§7. Se, por qualquer motivo, a conciliação não produzir resultados e não for adotado outro meio de solução do conflito, o juiz, na mesma audiência, fixará os pontos controvertidos, decidirá as questões processuais pendentes e determinará as provas a serem produzidas, designando audiência de instrução e julgamento, se necessário".

Art. 25 . Fica acrescentado no Código de Processo Civil - Lei n.. 5.869, de 11 de janeiro de 1.973 - o art. 331-A, com a seguinte redação:

"Art.331-A - Em qualquer tempo e grau de jurisdição, poderá o juiz ou tribunal adotar, no que couber, as providências previstas no artigo anterior".

Art.26. Esta Lei entrará em vigor no prazo de 6 (seis) meses da data de sua publicação.

Retirado de: http://www.pailegal.net/mediation.asp?rvTextoId=1981342874 


\section{PROJETO DE LEI № 632 , DE 2007}

Disciplina a criação dos Setores de Conciliação para as Varas Cíveis e de Família, em fase processual ou extraprocessual e dá outras providências.

\section{A ASSEMBLÉIA LEGISLATIVA DO ESTADO DE SÃO PAULO DECRETA:}

\section{CAPÍTULO I \\ DA INSTALAÇÃO DOS SETORES DE CONCILIAÇÃO CÍVEIS E DE FAMÍLIA E SUCESSÕES}

Artigo $1^{\circ}$ - Fica o Tribunal de Justiça do Estado de São Paulo autorizado a criar Setores de Conciliação das Varas Cíveis e de Família e Sucessões, para fins de realização de audiência de conciliação em processos já em tramitação, como, também, para realização de sessões de conciliação em expedientes extraprocessuais.

Artigo $2^{\circ}$ - Tanto as audiências de conciliação como as sessões de conciliação extraprocessuais contarão com a presença das partes e, quando já constituídos, de seus respectivos advogados, sendo os trabalhos conciliatórios supervisionados por Conciliadores, previamente nomeados pelo Presidente do Tribunal de Justiça do Estado, cujo ato de nomeação deverá ser publicado pela Imprensa Oficial.

Artigo $3^{\circ}$ - O Setor de Conciliação, preferencialmente, deverá:

I - ter instalações independentes das Varas Judiciais; e

II - contar com um Juiz Coordenador e um Juiz Auxiliar, ambos Juízes de Direito em exercício no respectivo Foro, cabendo, ao primeiro, a função de Juiz Corregedor dos servidores lotados no Setor.

Artigo $4^{\circ}$ - O processo será remetido pelo Juiz, de ofício ou a requerimento das partes, ao Juiz Coordenador, sendo da competência deste a designação da data da audiência, bem como, a determinação das intimações que se façam necessárias para a realização do ato, as quais serão cumpridas pelos servidores lotados no Setor de Conciliação. 
Artigo $5^{\circ}$ - Tramitarão pelo Setor de Conciliação, seja na fase processual, seja na extraprocessual, todos os litígios que envolvam direitos patrimoniais disponíveis e as causas que envolvam direito de família e sucessões.

$\S 1^{\circ}$ - Não haverá limitação de valor da causa dos litígios a serem remetidos para o Setor de Conciliação, nem vedação, quanto às partes, podendo envolver pessoas físicas ou jurídicas, como também crianças e adolescentes e incapazes.

$\S 2^{\circ}$ - Em processos onde haja a presença de crianças, adolescentes e incapazes, intervirá, sempre, o Representante do Ministério Público, na forma da lei processual vigente.

$\S 3^{\circ}$ - Ficam excluídas da competência do Setor de Conciliação as causas de interesse da Fazenda Pública.

\section{CAPÍTULO II}

\section{DA CONCILIAÇÃO}

Artigo $6^{\circ}$ - Para fins desta Lei, conciliação é a atividade técnica exercida por terceiro imparcial que, nomeado pelo Tribunal de Justiça, na presença das partes, as ouve, orienta e estimula à composição de um acordo ou transação, bem como apresenta soluções, com o propósito de lhes permitir a prevenção ou solução de conflitos, de modo consensual.

Artigo $7^{0}$ - É lícita a mediação em toda matéria que admita conciliação, reconciliação, transação ou acordo de outra ordem.

Artigo $8^{\circ}$ - A conciliação poderá versar sobre todo o conflito ou parte dele, sendo que em caso de acordo parcial, o processo prosseguirá quanto à parte não transacionada.

Artigo $9^{\circ}$ - A conciliação será sigilosa, assumindo o mediador e o conciliador, o compromisso do sigilo, no ato de sua nomeação. 
Artigo 10 - O termo de transação, subscrito pelo conciliador, judicial ou extrajudicial, pelos conciliadores e advogados e, quando o caso for, pelo Ministério Público, constitui título executivo judicial.

Parágrafo único - Se a transação for obtida em conciliação incidental, seu termo será submetido ao Juiz da causa ou ao Juiz Coordenador do Setor de Conciliação, que, após verificar o atendimento às formalidades legais, homologá-lo-á por sentença.

\section{Seção I}

Das modalidades de conciliação

Artigo 11 - É ato de conciliação todo aquele que reúna as partes para fins de transação e composição do litígio, intermediado por conciliador nomeado pelo Tribunal de Justiça, tanto em fase preventiva, como durante o processamento do feito.

Artigo 12 - O ato conciliatório poderá ser realizado preventivamente, antes da interposição da ação judicial, para contenção do conflito e solução da controvérsia envolvendo as partes, o que contará com a participação do conciliador nomeado.

$\S 1^{\circ}$ - Em caso de composição entre as partes, sob a coordenação do conciliador e com a participação efetiva dos advogados das partes, quando houver, os termos do acordo obtido será consignado formalmente.

$\S 2^{\circ}$ - Com a lavratura do acordo, este será imediatamente homologado pelo Juiz competente, por sentença de mérito fundamentada nos termos do artigo 269, inciso III do Código de Processo Civil, entregando-se, às partes, uma cópia assinada, e arquivando-se outra via original, também assinada, a ser arquivada em pasta própria, pelo Setor de Conciliação competente.

\section{Seção II}

Da conciliação processual

Artigo 13 - A conciliação também poderá ser obtida após a interposição da ação, em qualquer fase do processamento da lide, tanto nos termos do artigo 331 do Código de 
Processo Civil, como com fundamento nos termos do artigo 125, inciso IV da Lei Processual, desde o despacho inicial até a prolação da sentença pelo Juiz de primeiro grau, ou quando já sentenciado o feito, antes do julgamento do recurso.

$\S 1^{\circ}$ - A audiência de conciliação prevista no caput contará com a participação do Conciliador, bem como, dos advogados das partes que, juntamente com estas, firmarão o termo onde seja consignado o acordo obtido, se não homologado em primeiro grau pelo Juiz do processo ou de plantão e, em segundo grau, pelo Desembargador designado.

$\S 2^{\circ}$ - Caso a parte compareça desacompanhada de seu advogado, a audiência poderá ser redesignada uma vez, em um prazo de até 30 (trinta) dias, comprometendo-se a própria parte a comunicar ao seu advogado a data designada.

Artigo 14 - Obtido o acordo na fase processual, após assinatura das partes e de seus respectivos advogados, este será homologado pelo Juiz do processo, pelo Juiz Coordenador do Setor ou pelo Juiz de plantão, entregando-se uma cópia a cada uma delas, e arquivando-se o original assinado, em pasta própria do respectivo Setor.

\section{Setor III}

\section{Da Conciliação Extra Processual}

Artigo 15 - Recebido o requerimento de conciliação, será designado dia, hora e local onde realizará a sessão de conciliação, dando ciência aos interessados por qualquer meio eficaz.

Artigo 16 - A cientificação ao requerido conterá a advertência de que deverá comparecer à sessão acompanhado de advogado. Não tendo o requerido advogado constituído, o conciliador solicitará à Defensoria Pública ou, na falta desta, à Ordem dos Advogados do Brasil a designação de dativo. Na impossibilidade de pronto atendimento à solicitação, o conciliador imediatamente remarcará a sessão, deixando os interessados já cientificados da nova data e de que, em querendo, poderão se fazer acompanhar de seus respectivos advogados. 
Artigo 17 - A sessão de conciliação contará com a participação do conciliador nomeado pelo Tribunal de Justiça.

Artigo 18 - Obtida ou frustrada a transação, o conciliador lavrará o termo de acordo, descrevendo detalhadamente todas as cláusulas do mesmo, se for caso, ou consignando a sua impossibilidade.

Artigo 19 - A conciliação incidental será requerida por ambas as partes, a qualquer tempo ou grau de jurisdição, suspendendo-se o andamento do processo, até a realização da sessão ou audiência designada.

Artigo 20 - Cabe ao setor intimar as partes por qualquer meio eficaz de comunicação, designando dia, hora e local para seu comparecimento.

$\S 1^{\circ}$ - A intimação deverá conter a advertência de que as partes poderão se fazer acompanhar de advogados.

$\S 2^{\circ}$ - Caso já tenha se efetivado a citação, o prazo para oferta de contestação ficará suspenso, devendo ter sua contagem iniciada no dia seguinte à data da audiência de conciliação, caso as partes não tenham alcançado o acordo naquela, independente do rito processual da ação.

$\S 3^{\circ}$ - Se o requerido não tiver sido citado no processo judicial, a citação se efetivará no ato da audiência de conciliação, devendo o prazo para a contestação ter sua contagem iniciada a contar do dia seguinte da data da audiência de conciliação, independente do rito processual.

$\S 4^{\circ}$ - Se qualquer das partes não tiver advogado constituído nos autos do processo, o conciliador procederá de acordo com o disposto no artigo 16.

Artigo 21 - Havendo transação, o Juiz do processo, após verificar o preenchimento das formalidades legais, homologará o acordo por sentença. 
Parágrafo único - Se a transação for obtida quando o processo estiver em grau de recurso, a homologação do acordo caberá ao Relator.

\section{CAPÍTULO III}

\section{DOS CONCILIADORES}

Artigo 22 - Poderá ser conciliador qualquer pessoa capaz, que tenha conduta ilibada e formação técnica em curso de conciliação e mediação e experiência prática adequada à natureza do conflito, nos termos desta Lei.

Artigo 23 - Os conciliadores e mediadores prestarão serviços voluntariamente, estando, quando possível, adstritos à inscrição em convênio existente entre a Ordem dos Advogados do Brasil e a Defensoria Pública Geral do Estado para a prestação de Assistência Judiciária, advindo de tal convênio, neste caso, a possibilidade de remuneração, na forma prevista em tabela própria.

Artigo 24 - No desempenho de suas funções, o conciliador deverá proceder com imparcialidade, independência, aptidão, diligência e confidencialidade.

Artigo 25 - Caberá, em conjunto, à Ordem dos Advogados do Brasil, ao Tribunal de Justiça do Estado e às pessoas jurídicas especializadas em conciliação, nos termos de seu estatuto social, desde que, no último caso, devidamente autorizadas pelo Tribunal de Justiça do Estado em que estejam localizadas, a formação e seleção de conciliadores, para o qual, serão implantados os cursos apropriados, fixando-se os critérios de aprovação, com a publicação do regulamento respectivo em edital.

Artigo 26 - É lícita a conciliação coletiva de profissionais quando, pela natureza ou pela complexidade do conflito, for recomendável a atuação conjunta doconciliador com outro profissional especializado na área do conhecimento subjacente ao litígio. 
Parágrafo único - O regime de conciliação auxiliar estará adstrito a critério do conciliador ou a pedido das partes.

\section{CAPÍTULO IV}

\section{DO REGISTRO DE CONCILIADORES E MEDIADORES E DA FISCALIZAÇÃO E CONTROLE DA ATIVIDADE DE CONCILIAÇÃO}

Artigo 27 - O Tribunal de Justiça do Estado, nos limites de sua jurisdição, manterá registro de Conciliadores e Mediadores, contendo relação atualizada de todos os conciliadores habilitados a atuar, prévia ou incidentalmente, no âmbito do Estado.

$\S 1^{\circ}-$ O Tribunal de Justiça expedirá as normas que regulamentarão o processo de inscrição no Registro de Conciliadores.

$\S 2^{\circ}$ - Do Registro de Conciliadores constarão todos os dados relevantes referentes à atuação do conciliador, segundo os critérios fixados pelo tribunal de Justiça.

Artigo 28 - Na conciliação extrajudicial, a fiscalização das atividades dos conciliadores competirá sempre ao Tribunal de Justiça do Estado, na forma das normas específicas expedidas para este fim.

Artigo 29 - A distribuição dos processos ou procedimentos extrajudiciais aos conciliadores será feita por sorteio, realizado sob a responsabilidade do Diretor do Setor pertinente. Em caso de redesignação de audiência ou sessão, os autos será remetidos ao mesmo conciliador que iniciou os trabalhos.

\section{CAPÍTULO V}


Artigo 30 - A conciliação será sempre realizada em local de fácil acesso, com estrutura suficiente para atendimento condigno dos interessados, disponibilizado por entidade pública ou particular, dando-se preferência, às Universidades, para o desenvolvimento das atividades de que trata esta Lei.

Artigo 31 - Os serviços do conciliador poderão ser remunerados, nos termos e segundo os critérios fixados em norma a ser editada pelo Tribunal de Justiça do Estado, bem como estabelecer convênios com a Ordem dos Advogados do Brasil e a Defensoria Pública Geral do Estado no que se refere à questão remuneratória dos conciliadores.

Artigo 32 - O Tribunal de Justiça do Estado, no prazo de 60 dias, expedirá as normas indispensáveis à efetivação do disposto nesta Lei.

Artigo 33 - As despesas desta lei correrão à conta das dotações orçamentárias consignadas no orçamento do Tribunal de Justiça do Estado.

Artigo 33 - Esta Lei entra em vigor 90 dias após a data de sua publicação.

\section{JUSTIFICATIVA}

A apresentação do presente Projeto de lei visa atender à reivindicação de vários campos que trabalham diuturnamente com a prestação jurisdicional: juízes, promotores, advogados, procuradores e, em especial, as pessoas envolvidas em litígios e que buscam resolver suas contendas com a maior brevidade de tempo possível, mas com a sempre almejada decisão justa.

A criação dos Setores de Conciliação junto ao Tribunal de Justiça do Estado de São Paulo objetiva dotar o nosso Poder Judiciário local de condições e métodos de solução pacífica de conflitos intersubjetivos de interesse sem cair no ranço burocrático.

Engajada no compromisso de ajudar a promover o bem-estar dos cidadãos que batem às portas dos tribunais pedindo Justiça, é que a Assembléia Legislativa do Estado de São Paulo, calcada em permissivo constitucional previsto no artigo 24, inciso XI da 
Constituição Federal, oferta, à sociedade, um novo instrumento de satisfação pacífica das suas pendências, colaborando, também, com a promoção da cidadania em solo paulista.

Sala das Sessões, em 26/6/2007

a) Rodrigo Garcia - DEM 


\section{PROJETO DE LEI No , DE 2005 \\ (Do Sr. NELSON MARQUEZELLI)}

Regula o exercício das profissões de Árbitro e Mediador e dá outras providências.

O Congresso Nacional decreta:

\section{TÍTULO I \\ DO EXERCÍCIO PROFISSIONAL DA ARBITRAGEM E MEDIAÇÃO CAPÍTULO I \\ SEÇÃO I \\ DAS ATIVIDADES PROFISSIONAIS}

Art. $1^{\circ}$ As profissões de Árbitro e Mediador são caracterizadas pela realização do interesse social e humano que importe na implementação do seguinte:

a) resolver conflitos ou controvérsias relativas a direito patrimonial disponível;

b) resolver controvérsias ou disputas negociais, contratuais, familiares, escolares, trabalhistas, educacionais, comunitárias, hospitalares, médicas e ecológicas;

c) colaborar com a criação e circulação de riqueza no âmbito nacional e internacional;

d) implementar a geração de confiança nos negócios entre nacionais e destes com os estrangeiros; 
e) colaborar com a paz social das pessoas e instituições, introduzindo, na cultura brasileira, novo componente para a solução de controvérsias, "a inteligência e a criatividade".

Art. $2^{\circ} \mathrm{O}$ exercício, no País, da profissão de Árbitro e Mediador, observadas as condições de capacidade e demais exigências legais, é assegurado:

a) aos que possuam diplomas ou certificados, devidamente registrados nos Conselhos Regionais e/ou Federal, de escolas oficiais ou reconhecidas no País;

b) aos que possuam, devidamente revalidado e registrado no País, diploma de faculdade ou escola estrangeira de ensino ou tenha exercício amparado por convênios internacionais de intercâmbio;

c) aos que provarem, perante o Conselho, pelo menos dois anos de experiência.

\section{SEÇÃO II \\ DO USO DO TÍTULO PROFISSIONAL}

Art. $3^{\circ}$ É reservado exclusivamente para os profissionais referidos nesta Lei e que observam as suas normas, a denominação de Árbitro e Mediador.

Parágrafo único. As denominações Arbitragem e Mediação só poderão ser usadas por pessoas jurídicas compostas por profissionais da área e que se dediquem efetivamente à sua prática.

\section{SEÇÃO III DO EXERCÍCIO ILEGAL DA PROFISSÃO}

Mediador:

Art. $4^{\circ}$ Exerce ilegalmente a profissão de Árbitro ou

a) toda a pessoa física ou jurídica, sociedade, associação ou organização que realizar atos ou prestar serviços privativos ou reservados aos 
profissionais de que trata esta Lei e que não possuam registro nos Conselhos Regionais ou Federal;

b) os profissionais que, suspensos de seu exercício, continuem em atividade;

c) toda empresa, organização, sociedade, associação que se dediquem ao mister da arbitragem e mediação, sem o devido registro seu e dos seus profissionais.

\section{SEÇÃO IV \\ ATRIBUIÇÕES PROFISSIONAIS E COORDENAÇÃO DA ATIVIDADE}

Art. $5^{\circ} \mathrm{O}$ Conselho Federal organizará e manterá atualizada a relação dos títulos concedidos pelas escolas e faculdades, bem como seus cursos e currículos.

Art. $6^{\circ}$ Caberá às Congregações das Escolas e Faculdades indicar ao Conselho Federal as características dos profissionais por elas diplomados.

Art. $7^{\circ}$ A União, Estados, Municípios e Distrito Federal, bem como as autarquias, entidades paraestatais e de economia mista, somente poderão exercer as atividades previstas nesta Lei através de profissionais devidamente habilitados.

Art. $8^{\circ}$ Serão nulos de pleno direito os contratos firmados por pessoa física, jurídica ou entidades públicas ou particulares com pessoas físicas ou jurídicas não habilitadas à prática das atividades previstas por esta Lei.

\section{CAPÍTULO II DA RESPONSABILIDADE}

Art.9 $9^{\circ}$ Os Árbitros e Mediadores são responsáveis e equiparados aos funcionários públicos para o efeito da legislação penal, podendo, assim, responder por crimes de Peculato, nas suas modalidades de apropriação ou posse, Extravio, Sonegação ou Utilização de Livro ou Documento; Concussão, quando exigir vantagem indevida; Excesso de Exação, se exigir, taxas e emolumentos indevidos; Corrupção Passiva, quando solicitar ou aceitar vantagem 
indevida; Prevaricação, quando retarda ou deixa de praticar, indevidamente, ato de ofício; Condescendência Criminosa em relação a funcionários subordinados; Violência Arbitrária no exercício da função e Violação do Sigilo Funcional.

\section{TíTULO II \\ DA FISCALIZAÇÃO DO EXERCÍCIO DA PROFISSÃO CAPÍTULO I DOS ÓRGÃOS FISCALIZADORES}

Art. 10. A aplicação do que dispõe esta Lei, no âmbito da fiscalização, exercício e atividades das profissões nela regulamentada, será exercida por um Conselho Federal e Conselhos Regionais organizados de forma a assegurar uma unidade de ação sistêmica.

Art. 11. O Conselho Federal será constituído, originariamente, em seu primeiro mandato, por um Presidente e demais integrantes da Diretoria, por escolha do Ministério da Justiça, mediante lista apresentada pelo IINAJUR - Instituto Internacional de Altos Estudos Jurídicos. Este Conselho Federal promoverá a instalação e o funcionamento em cada unidade da Federação de um Conselho Regional destinado a operacionalizar esta Lei.

$\S 1^{\circ} \quad$ O Conselho Federal tem foro e sede no Distrito

Federal.

$\S 2^{\circ}$ Os Conselhos Regionais terão sede em cada Capital da unidade administrativa federada e serão criados por proposta das entidades de classe ao Conselho Federal, limitados a um para cada Estado.

$\S 3^{\circ}$ No Distrito Federal, as atribuições do Conselho Regional serão absorvidas pelo Conselho Federal, tendo em vista a necessidade de redução de custos e burocracia. 


\section{CAPÍTULO II \\ DO CONSELHO FEDERAL \\ SEÇÃO I \\ DA INSTITUIÇÃO DO CONSELHO FEDERAL E SUAS ATRIBUIÇÕES}

Art. 12. O Conselho Federal é a instância superior da fiscalização e controle do exercício profissional.

Art. 13. São atribuições do Conselho Federal:

a) organizar o seu regimento interno e estabelecer normas gerais para os regimentos dos Conselhos Regionais;

b) homologar os regimentos internos organizados pelos Conselhos Regionais;

c) examinar e decidir, em última instância, os assuntos relativos ao exercício das profissões, podendo anular qualquer ato que não estiver de acordo com a presente lei;

d) tomar conhecimento e dirimir quaisquer dúvidas suscitadas nos Conselhos Regionais;

e) julgar, em última instância, os recursos sobre registros, decisões e penalidades impostas pelos Conselhos Regionais;

f) baixar e fazer publicar as resoluções previstas para regulamentação e execução da presente Lei e, ouvidos os Conselhos Regionais, resolver os casos omissos;

g) relacionar os cargos e funções dos serviços estatais, paraestatais, autárquicos e de economia mista, para cujo exercício seja necessário o título de Árbitro ou Mediador;

h) incorporar ao seu balancete de receita e despesa os dos Conselhos Regionais;

i) enviar aos Conselhos Regionais, cópia do expediente encaminhado ao Tribunal de Contas até 30 (trinta) dias após a remessa; 
j) publicar anualmente a relação de títulos, cursos e escolas de ensino superior, assim como, periodicamente, relação de profissionais habilitados;

k) fixar, ouvido o respectivo Conselho Regional, as condições para que as entidades de classe da região tenham nele direito à representação;

I) promover, pelo menos uma vez por ano, as reuniões de representantes dos Conselhos Federal e Regionais;

m) examinar e aprovar a proporção das representações dos grupos profissionais nos Conselhos Regionais;

n) julgar, em grau de recurso, as infrações ao Código de Ética Profissional do Árbitro e Mediador, elaborado pelas entidades de classe;

o) aprovar ou não as propostas de criação de novos Conselhos Regionais;

p) fixar e alterar as anuidades, emolumentos e taxas devidas pelos profissionais e pessoas jurídicas;

q) autorizar o Presidente a adquirir, onerar ou mediante licitação, alienar bens imóveis;

r) dispor, em resolução, sobre os procedimentos eleitorais referentes à organização e data das eleições, prazos de desincompatibilização, apresentação de candidaturas e tudo o mais que se fizer necessário à realização dos pleitos;

s) incorporar, no Distrito Federal, as atribuições do Conselho Regional e decidir em única e última instância por maioria simples, questões relativas à votação e eleições de fontes de lei e procedimento judicial.

Parágrafo único. Nas questões relativas a atribuições profissionais, a decisão do Conselho Federal só será tomada com o mínimo de dois terços dos presentes. 
Art. 14. Constitui renda do Conselho Federal:

a) Quinze por cento do produto de arrecadação efetuada pelos Conselhos Regionais;

b) Doações, legados, juros e receitas patrimoniais;

c) Subvenções e um quinto do adicional da contribuição de que trata o $\S 3^{\circ}$ do art. $8^{\circ}$ da Lei $n^{\circ} 8.029$, de 12/04/90;

d) Outros rendimentos eventuais.

$\S 1^{\circ}$ Os orçamentos dos Conselhos Regionais serão disciplinados, fiscalizados e integrados ao do Conselho Federal, no sentido de suprir e complementar os Regionais mais carentes de recursos técnicos e financeiros.

$\S 2^{\circ}$ Todos os filiados ligados ao sistema "S" (SESC, SENAC, SESI, SENAR, SEBRAE e outros) poderão usufruir do instituto da Arbitragem/Mediação e de seus serviços, em prol de pequenos, médios e grandes empreendimentos.

\section{SEÇÃO II \\ DA COMPOSIÇÃO E ORGANIZAÇÃO}

Art. 15. O Conselho Federal será constituído por 15(quinze) brasileiros natos ou naturalizados, diplomados, habilitados de acordo com esta Lei, obedecida a seguinte composição:
a) Um presidente;
b) Um Vice Presidente;
c) Um Secretário Geral;
d) Um Diretor Administrativo;
e) Um Diretor Financeiro;
f) Três titulares e três suplentes da Comissão Fiscal; 
g) Três integrantes da Comissão de Ética;

h) Quatro integrantes do Centro de Estudos e Debates.

$\S 1^{\circ}$ Todos os integrantes do Conselho serão eleitos pelo voto direto e secreto dos profissionais registrados e em dia com suas obrigações perante a entidade, podendo candidatar-se somente os profissionais brasileiros habilitados de acordo com esta Lei.

$\S 2^{\circ} \mathrm{A}$ escolha dos candidatos será sempre com um titular e um suplente, com mandatos de 3 (três) anos.

\section{CAPÍTULO III DOS CONSELHOS REGIONAIS SEÇÃO I DA INSTITUIÇÃO DOS CONSELHOS REGIONAIS E SUAS ATRIBUIÇÕES}

Art. 16. Os Conselhos Regionais são órgãos de fiscalização do exercício das profissões em suas regiões.

Art.17 - São atribuições dos Conselhos Regionais:

a) elaborar e alterar seu regimento interno, submetendo-o à homologação do Conselho Federal;

b) criar as Câmaras Especializadas atendendo às condições de maior eficiência da fiscalização estabelecida na presente lei;

c) examinar reclamações e representações acerca de registros;

d) julgar e decidir, em grau de recurso, os processos de infração da presente Lei e do Código de Ética, enviados pelas Câmaras Especializadas;

e) julgar, em grau de recurso, os processos de imposição de penalidades e multas; 
f) organizar o sistema de fiscalização do exercício das profissões reguladas pela presente Lei;

g) publicar relatórios de seus trabalhos e relação de profissionais e firmas registrados;

h) examinar os requerimentos e processos de registro em geral, expedindo as carteiras profissionais ou documentos de registro;

i) sugerir ao Conselho Federal medidas necessárias à regularidade dos serviços e à fiscalização do exercício das profissões reguladas nesta Lei;

j) agir, com a colaboração da sociedade de classe e das escolas ou faculdades, nos assuntos relacionados com a presente Lei;

k) cumprir e fazer cumprir a presente Lei, as resoluções baixadas pelo Conselho Federal, bem como expedir atos que para isso julguem necessários;

I) deliberar sobre assuntos de interesse geral e administrativos e sobre os casos comuns a duas ou mais especializações profissionais;

m) julgar, decidir ou dirimir as questões de atribuição ou competência das Câmaras Especializadas quando não possuir o Conselho Regional número suficiente de profissionais do mesmo grupo para constituir a respectiva Câmara;

n) organizar, disciplinar e manter atualizado o registro dos profissionais e pessoas jurídicas que, nos termos desta Lei, se inscrevam para exercer atividades;

o) organizar e manter atualizado o registro das entidades de classe e das escolas e faculdades que, de acordo com esta Lei, devam participar do preparo profissional; 
p) autorizar o Conselho a adquirir, onerar ou mediante licitação, alienar bens imóveis;

q) registrar as tabelas básicas de honorários profissionais elaboradas pelos órgãos de classe.

Art. 18. Constitui renda do Conselho Regional:

a) as anuidades cobradas dos profissionais e das pessoas jurídicas;

b) taxas de expedição de carteira de profissionais e documentos diversos;

c) multas aplicadas de conformidade com esta Lei, variando a pena pecuniária conforme valores estabelecidos pelos Conselho Federal, revistos anualmente;

d) doações, legados, juros e receitas patrimoniais;

e) subvenções e outros rendimentos eventuais.

$\S 1^{\circ}$ Os Conselhos Regionais recolherão ao Conselho Federal, até o dia trinta do mês subseqüente ao da arrecadação, a quota de participação estabelecida no art. 14, inciso I;

$\S 2^{\circ}$ Os Conselhos Regionais poderão destinar parte de sua renda liquida, proveniente da arrecadação das multas, ao aperfeiçoamento técnico e cultural dos profissionais e das entidades de classe.

\section{SEÇÃO II COMPOSIÇÃO E ORGANIZAÇÃO}

Art. 19. Os Conselhos Regionais serão compostos por 15 (quinze) brasileiros natos ou naturalizados, com cursos especializados, legalmente habilitados de acordo com a presente Lei, obedecida a seguinte composição:

a) Um Presidente; 
b) Um Vice Presidente;

c) Um Secretário Geral;

d) Um Diretor Administrativo;

e) Um Diretor Financeiro;

f)Três integrantes da Comissão Fiscal: três titulares e três suplentes;

g)Três integrantes da Comissão de Ética;

h) Quatro integrantes do Centro de Estudos e Debates.

$\S 1^{\circ}$ Os integrantes dos Conselhos Regionais serão eleitos consoante o que consta nos $\S \S 1^{\circ}$ e $2^{\circ}$ do art. 15 desta Lei.

$\S 2^{\circ} \quad$ Os Conselhos Regionais funcionarão em Pleno e, para os assuntos específicos da Arbitragem e da Mediação, em Câmaras especiais, com atribuições de julgar infrações previstas no Código de Ética, aplicar penalidades e multas previstas nesta Lei, bem como apreciar pedido de registros de profissionais da área bem como das firmas, empresas ou entidades voltadas ao setor da Arbitragem ou Mediação, e, ainda, opinar sobre assuntos de interesse comum das duas ou mais especializações, encaminhando-as ao Conselho Regional.

$\S 3^{\circ}$ Cada Conselho Regional terá uma inspetoria para fiscalização nas cidades ou zonas, onde se fizer necessária.

\section{CAPITULO V DISPOSIÇÕES GERAIS}

Art. 20. Os Conselhos Regionais e Federal, são entidades civis sem fins lucrativos. Embora desvinculados do Estado, cumprem, por delegação deste, serviço público relevante e de interesse da sociedade, tendo por fim ultimar a paz social e a solução de conflitos de natureza patrimonial disponíveis, no sentido de garantir o desenvolvimento nacional, em face da 
confiabilidade que imprimirá aos atos negociais e, por via de conseqüência, a erradicação da pobreza.

$\S 1^{\circ}$ Os serviços de fiscalização das profissões de Árbitros e Mediadores e das entidades especializadas serão exercidos em caráter privado e por delegação do poder público, possuindo para tanto o poder de polícia em relação à fiscalização, autuação e aplicação de multas, cobrança de taxas e anuidades, os quais serão efetuados consoante o previsto na Lei de Execuções Fiscais.

$\S 2^{\circ}$ A organização, estrutura e funcionamento dos Conselhos Regionais serão disciplinados mediante decisão do Conselho Federal.

$\S 3^{\circ} \mathrm{O}$ controle das atividades financeiras e administrativas dos Conselhos Regionais e Federal serão realizados por seus órgãos internos, devendo os Conselhos Regionais prestar contas, anualmente ao Conselho Federal, o qual prestará contas, sem vínculo, ao Tribunal de Contas da União.

Art. 21. Aos Presidentes do Conselho Federal e Regionais compete, além da direção do respectivo Conselho, sua representação em juízo.

$\S 1^{\circ} \mathrm{O}$ mandato de Presidentes e dos Conselheiros, como previsto no art. 15, será honorífico e considerado serviço relevante prestado à Nação, independentemente de requerimento do interessado, e, por via de conseqüência, como serviço público efetivo para o efeito de aposentadoria e disponibilidade, vedado a contagem cumulativa.

$\S 2^{\circ}$ Os representantes do Conselho Federal e Regionais reunir-se-ão pelo menos uma vez por ano para, conjuntamente, estudarem e estabelecerem providências que assegurem ou aperfeiçoem a aplicação da presente Lei, devendo o Conselho Federal remeter aos Regionais, com a devida antecedência, o ternário respectivo.

$\S 3^{\circ} \mathrm{O}$ Conselheiro Federal ou Regional que faltar, sem justificação, a seis sessões, durante um ano, perderá automaticamente o mandato que será exercido em caráter efetivo pelo suplente. 
$\S 4^{\circ}$ Ao Conselho Federal é cometido o encargo de dirimir qualquer dúvida ou omissão contida nesta Lei, a qual será efetuada através de ato normativo, obrigatoriamente seguido pelos Regionais.

\section{TÍTULO III \\ CAPÍTULO I \\ DO REGISTRO DE FIRMAS, EMPRESAS, ÓRGÃOS ARBITRAIS OU ENTIDADES ESPECIALIZADAS COM OU SEM PERSONALIDADE JURÍDICA PRÓPRIA}

Art. 22. As entidades, empresas, sociedades ou associações, com ou sem personalidade jurídica própria, que se organizarem para acolher, gerir, administrar ou executar atividades, relacionadas a prestação de serviço dos Árbitros ou Mediadores, só poderão iniciar ou exercer suas atividades se devidamente registradas nos Conselhos Regionais, tendo também registrado os profissionais de seu quadro.

$\S 1^{\circ} \bigcirc$ Conselho Federal estabelecerá os requisitos necessários para o referido registro.

$\S 2^{\circ} \mathrm{O}$ registro das entidades acima referidas implicará no recolhimento das taxas e anuidades previstas nesta Lei.

\section{CAPÍTULO II \\ DO REGISTRO E FISCALIZAÇÃO PROFISSIONAL}

Art. 23. Os profissionais habilitados na forma desta Lei só poderão exercer a profissão após o registro no Conselho Regional, sob cuja jurisdição se achar o local de sua atividade.

$\S 1^{\circ}$ Aos profissionais registrados na forma do artigo acima, são fornecidas carteiras profissionais, conforme modelo adotado pelo Conselho Federal, a qual substituirá o diploma e valerá, em todo território nacional como documento de identidade e terá fé pública.

$\S 2^{\circ}$ Para a expedição da carteira, deverá o interessado apresentar prova da habilitação profissional e identidade, bem como pagar as taxas respectivas. 
Art. 24 Se o profissional, empresa ou entidade registrada em qualquer Conselho Regional exercer atividade em outra região, ficará obrigado a visar, na sua carteira, o seu registro.

\section{CAPITULO III \\ DAS ANUIDADES, EMOLUMENTOS E TAXAS}

Art. 25. Os profissionais e pessoas jurídicas registradas de acordo com o que preceitua esta Lei ficam obrigados ao pagamento de uma anuidade ao Conselho Regional, a cuja jurisdição pertencerem.

$\S 1^{\circ} \mathrm{A}$ anuidade será devida a partir de 10 de janeiro de cada ano, sendo o pagamento, após 31 de março, acrescido de $20 \%$, quando efetuado no mesmo exercício e no seguinte, atualizada monetariamente com a respectiva multa.

$\S 2^{\circ}$ Será automaticamente cancelado o registro do profissional e pessoa jurídica que deixar de efetuar o pagamento das anuidades durante dois anos consecutivos, sem prejuízo da obrigação de pagamento da dívida.

$\S 3^{\circ} \mathrm{O}$ profissional ou pessoa jurídica que tiver o seu registro cancelado e exercer por qualquer meio ou forma as atividades reguladas por esta Lei, estará exercendo ilegalmente a profissão, sendo a sua reabilitação sujeita ao prévio pagamento das anuidades, taxas e emolumentos da Região de origem.

Art. 26. O Conselho Federal baixará resoluções estabelecendo o Regimento de Custas e, periodicamente, quando julgar oportuno, promoverá sua revisão.

\section{TITULO IV \\ DAS PENALIDADES}

Art. 27. As penalidades aplicáveis por infração da presente Lei, são as seguintes:

a) advertência reservada; 
b) censura pública;

c) multa;

d) suspensão temporária do exercício profissional;

e) cancelamento definitivo do registro.

Parágrafo único. As penalidades de cada grupo de profissional, Árbitros ou Mediadores, serão impostas pelas respectivas Câmaras especializadas ou, na falta destas, pelos Conselhos Regionais.

Art. 28. As penas previstas nas letras "a" e "b" do art. 27, serão aplicadas aos profissionais que deixarem de cumprir o Código de Ética, sendo as multas nos valores de UFIRs, aplicáveis aos profissionais ou pessoas jurídicas por qualquer infração aos dispositivos desta Lei, com a aplicação em dobro nos casos de reincidência.

Art. 29. A pena de suspensão temporária variará de 6 meses a 2 anos, sendo o cancelamento do registro aplicado à má conduta ou condenação criminal.

Art. 30. As pessoas não habilitadas e que exercerem as profissões reguladas nesta Lei, além da multa, estarão sujeitas às penalidades previstas na legislação penal.

Art. 31. Das penalidades impostas pelas Câmaras Especializadas, poderá o interessado, dentro do prazo de 30 dias, contados da data da notificação, interpor recurso que terá efeito suspensivo para o Pleno do Conselho Regional e, no mesmo prazo, para o Conselho Federal.

\section{TÍTULO V \\ DISPOSIÇÕES FINAIS}

Art. 32. Os Conselhos Federal e Regionais, dotados de personalidade jurídica privada, constituem-se em serviço público relevante, gozando seus bens, rendas e serviços de imunidade tributária (art. 150, VI, letra "a" da Constituição Federal) e franquia postal e telegráfica. 
Art. 33. A remuneração dos Árbitros e Mediadores será fixada, em seus valores mínimos regionalmente, ouvido o Conselho Federal, não podendo haver concorrência de preços.

\section{TÍTULO VI \\ DAS DISPOSIÇÕES TRANSITÕRIAS}

Art. 34. Na constituição do primeiro Conselho Federal, após a publicação desta Lei, será empossado seu presidente e diretores pelo Ministro da Justiça.

Art. 35. Os Conselhos Regionais serão constituídos no prazo de 12 meses a partir da publicação desta Lei, consoante instruções baixadas pelo Conselho Federal.

Art. 36. Os Conselhos Federal e Regionais, completados na forma desta Lei, terão o prazo de 180 (cento e oitenta) dias após a posse, para elaborar os seus regimentos internos.

Art. 37. Esta Lei entra em vigor na data de sua publicação.

\section{JUSTIFICAÇÃO}

A globalização da economia, da qual nenhum cidadão deste planeta ficará à margem, está a imprimir em todas as operações e atividades econômicas, diretrizes universais padronizadas, baseadas na velocidade das comunicações e dos transportes, exigindo como conseqüência mudanças radicais nas estruturas políticas, sociais e jurídicas do Estado e da iniciativa privada, para que assim possam acompanhar, direcionar e resolver questões de interesse das pessoas e das organizações.

A edição da Lei $n^{\circ}$ 9.307/96, que dispõe sobre a arbitragem, pode ser entendida como uma das principais reformas do ordenamento jurídico pátrio dos últimos tempos, vez que veio a disciplinar instituto eficaz e célere para a composição de litígios, que se encontrava adormecido em nosso DIREITO por mais de um século, diante da FALTA DE PRATICIDADE, posto exigir, 
necessariamente, uma homologação judicial, ocasião em que se reexaminava todo o processo arbitral, o que foi espancado nessa nova norma.

Efetiva-se, através de ARBITRAGEM, a possibilidade de alcançar a redução do "CUSTO BRASIL", via utilização de um expediente para a solução de conflitos mais célere, informal, sigiloso, onde as decisões são respaldadas na especialização técnicas dos ÁRBITROS, possibilitando, no início ou durante o procedimento, uma CONCILIAÇÃO que venha a atender ao interesse de ambas as partes.

Através da ARBITAGEM e MEDIAÇÃO, os agentes sociais e sobretudo os profissionais ligados às ciências jurídicas, tendem a desenvolver uma mentalidade de substituição dos excessos da LITIGIOSIDADE por uma madura busca da pacificação das disputas sociais, onde A FORÇA e a COERÇÃO são substituídas pela TÉCNICA, INTELIGÊNCIA e CRIATIVIDADE.

Mister se faz ressaltar que a ARBITRAGEM, além de resolver aspectos jurídicos relevantes, resolve, também, questões de elevado interesse econômico e social, no âmbito nacional e internacional, público e privado, tais como: investimentos de capitais, transferência de tecnologia, "joint ventures", propriedade intelectual, seguros, resseguros, contratos e constituição/alteração/fusão/cisão de sociedades mercantis, operações imobiliárias, operações bancárias, questões sobre negócios marítimos, aeronáuticos, mercado de capitais, contratos rodoviários, ferroviários e marítimos etc, que têm no INSTITUTO um dos essenciais pontos positivos para a confiança dos negócios entre nacionais e destes com os estrangeiros, notadamente no campo das exportações/importações.

Dessa forma, o instituto da ARBITRAGEM/MEDIAÇAO resulta num dos componentes fundamentais para o incremento de negócios, vindo ao encontro dos mais altos interesses nacionais, constante no art. $3^{\circ}$, incisos II e III da CARTA MAGNA de 1988, no sentido de CONTRIBUIR para a GARANTIA DO DESENVOLVIMENTO NACIONAL E ERRADICAR A PROBREZA. 
Entretanto, como toda nova instituição é objeto da cobiça e má interpretação de pessoas inescrupulosas, muitos desvios ocorreram e continuam a ocorrer, como no notório caso de vendas de carteiras no Estado do Rio de Janeiro e, que por falta de um poder de polícia devidamente regulamentado, ficam impunes e no esquecimento, acarretando inestimáveis danos sociais, posto que maculam o novel INSTITUTO, que desempenhará em nosso País papel relevante na paz social. Para tanto, necessário se faz regulamentar a profissão dos ÁRBITROS e MEDIADORES, bem como das atividades de entidades especializadas, a fim de manter no Brasil elevado nível de procedimento no aspecto técnico e ético. Nesse sentido, embora a lei da arbitragem estabeleça ( art. 13 ) que qualquer pessoa que goze da confiança das partes poderá ser árbitro, o parágrafo $6^{\circ}$ exige, para o exercício da função, entre outros a COMPETÊNCIA, requisito indispensável para uma solução respaldada em uma especialização técnica, como a que ocorreu por ocasião da instalação da usina nuclear ANGRA II, cuja questão de sua localização foi decidida através de uma arbitragem.

A organização da profissão através dos CONSELHOS REGIONAIS e FEDERAL trará um incremento necessário à referida atividade com resultados efetivos de uma ORGANIZAÇÃO SISTÊMICA, que operará dentro dos preceitos de harmonia e uniformidade, que potencializará os valores e as crenças calcadas na vontade de cumprir, na sua plenitude, a responsabilidade de ajudar a transformar a sociedade brasileira, induzindo a confiança nos negócios e nas atividades negociais, para o fortalecimento das pequenas, médias e grandes empresas nacionais e, por via de conseqüência, para o desenvolvimento nacional, a geração de empregos e, por via de conseqüência, a melhoria da qualidade de vida.

Tarefa dessa envergadura, merece o apoio e a participação do Estado, vez que a criação dos CONSELHOS dos referidos profissionais permitirá inibir irregularidades no exercício da profissão, sem que haja aumento ou criação de outros encargos ou tributos, louvando-se apenas no mecanismo de redistribuição de parcela mínima do adicional da contribuição social destinadas às 
entidades SESC, SENAI, SESI e SEBRAE, bem como na arrecadação da anuidade dos profissionais e entidades administradoras.

Merece destaque a importância dada pela Lei $n^{\circ}$ 9.307/96 na criação da JURISIDIÇÃO PRIVADA, ao conferir, pelo Estado, ao JUIZ ARBITRAL os mesmos poderes decisórios que ao JUIZ TOGADO (ART.31), devendo para tanto haver a devida qualificação do referido cidadão e profissional quando no exercício da função.

Como a lei não contém termos ou palavras inúteis, a criação dessa jurisdição privada, pela norma acima, vem ao encontro do mais alto interesse nacional, tanto no âmbito interno como internacional, a exemplo de todos os países de destaque no MUNDO GLOBALIZADO, cuja integração o nosso País não poderia ficar alheio. Entretanto, diante do alto grau de especialização, tanto no campo técnico como ético, a referida JURISDIÇÃO não poderá FICAR órfã de um órgão de supervisão e fiscalização, indispensável para o seu efetivo desempenho.

Por derradeiro, mister se faz destacar que a PRESTAÇÃO JURISDICIONAL, tanto pública como PRIVADA, encontra-se entre as principais atividades requeridas pelas COMUNIDADES para a PAZ SOCIAL e diante das dificuldades, públicas e notórias em que se encontra o PODER JUDICIÁRIO, cresce a importância dessa jurisdição PRIVADA para a satisfação dos interesses dos cidadãos, dentro de um processo rápido, informal e efetivo, do qual ele não pode mais prescindir.

Sala das Sessões, em de de 2005.

NELSON MARQUEZELLI

Deputado Federal PTB/SP 


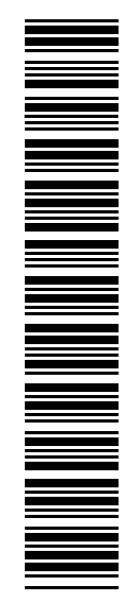

กิ

嵌

ய

니

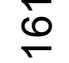




\title{
COMISSÃO DE CONSTITUIÇÃO E JUSTIÇA E DE CIDADANIA
}

\section{SUBSTITUTIVO AO PROJETO DE LEI № 4.827-C, DE 1998 \\ (do Senado Federal)}

\author{
Institucionaliza e disciplina a \\ mediação, com método de prevenção e \\ solução consensual de conflitos.
}

Autor: Senado Federal

Relator: Deputado José Eduardo Cardozo

\section{I - RELATÓRIO}

O projeto de lei em epígrafe busca disciplinar o instituto da mediação, conceituando-o como "a atividade técnica exercida por terceira pessoa, que escolhida ou aceita pelas partes interessadas, as escuta e orienta com o propósito de lhes permitir que, de modo consensual, previnam ou solucionem conflitos".

A Proposição foi aprovada pelo Plenário da Casa e enviada ao Senado Federal, que a aprovou na forma de Substitutivo.

Compete a esta Comissão de Constituição e Justiça e de Cidadania analisar a proposta sob os aspectos de constitucionalidade, juridicidade, técnica legislativa e mérito, sendo a apreciação final do Plenário da Casa.

É o Relatório. 


\section{II - VOTO DO RELATOR}

Da mesma forma como ocorreu quando da apreciação da Proposição anteriormente, pelo Plenário da Casa, não há no Substitutivo do Senado Federal vícios de natureza constitucional, que o inviabilizem totalmente, de juridicidade ou de técnica legislativa.

O substitutivo apresentado pelo Senado inova ao permitir que o poder público exerça controle sobre a qualidade da mediação. A atenção voltada para itens como a formação do mediador, as condições do local em que a mediação deverá ser realizada e a atribuição do poder de fiscalização ao Tribunal de Justiça, à Defensoria Pública e à Ordem dos Advogados do Brasil, tem como objetivo assegurar a qualidade do serviço prestado ao jurisdicionado.

Diante disso, entendemos que, no mérito, como se pode facilmente verificar, há sensível melhoria ofertada pelo Substitutivo do Senado Federal.

A mediação como método alternativo extrajudicial privado, de prevenção e solução sigilosa de conflitos, deve sobremaneira aliviar o enorme trabalho do Poder Judiciário.

A mediação é tão antiga quanto a humanidade, e pode ser exercida por qualquer pessoa, desde que tenha formação técnica adequada. Um terceiro imparcial expressa suas opiniões sobre o caso, que podem ou não ser acatadas pelas partes, oferecendo uma solução pacífica e amigável às partes.

Esse processo pode ser o suficiente para solucionar o problema entre as partes, descartando, então, os transtornos provocados pela via judicial. A mediação deve ocorrer sem prejuízo de eventual recurso à arbitragem ou à Justiça.

Pelo exposto, nosso voto é pela constitucionalidade, juridicidade, boa técnica legislativa e no mérito pela aprovação do Substitutivo do Senado Federal ao Projeto de Lei no 4.827-C, de 1998. 
Sala da Comissão, em de de 2006.

\section{Deputado JOSÉ EDUARDO CARDOZO}

Relator

2006_8162_José Eduardo Cardozo_058 


\section{ATA DA REUNIÃO DO FONAME \\ LOCAL: CEBEPEJ - 13/09/07}

1. O Dr. Kazuo Watanabe fez a abertura dos trabalhos, afirmando que, apesar de haver muitas instituições que atuam com mediação, não há um canal de comunicação entre elas. Portanto, o objetivo dos encontros é promover o contato entre as diversas entidades que cuidam do tema.

Registrou que a mediação/conciliação ganhou muita força nos dias atuais; o CNJ manterá o dia nacional da conciliação ("conciliar é legal").

Há muitos pontos a serem discutidos e experiências a serem trocadas.

No último encontro, surgiu a idéia de criar uma espécie de fórum, sem personalidade jurídica, mantendo a individualidade das instituições que participarem, cuja minuta de regulamento foi preparada pelo professor Freitas e deve ser discutida nesta reunião.

2. Os integrantes do grupo fizeram breve apresentação de suas atividades.

3. Célia Zapparolli explicou o surgimento da idéia a partir da necessidade de congregar as instituições que cuidam da mediação no âmbito paulista e, posteriormente, nacional; para cuidar não apenas de mediação, mas, eventualmente, outras modalidades de "ADR" (alternative dispute resolution - meios alternativos de solução de controvérsias). A congregação viabilizará a unidade no posicionamento e proposta de reformas legislativas e de políticas públicas.

4. Adolfo Braga reforçou a preocupação de que as instituições não percam a sua identidade, e que a congregação se de com base em elementos comuns e com padrão de qualidade.

5. Kazuo Watanabe anotou sua preocupação com o desnível dos mediadores: não há um padrão mínimo de sua qualificação. Com a experiência de cada um dos participantes do FONAME, esse padrão mínimo poderia ser modelado.

Se a lei da mediação para-processual for aprovada, sem estabelecimento de critérios para a qualificação do mediador, essa atribuição normativa poderá ficar a cargo da OAB e Tribunais de Justiça, o que causará muitas diferenças ao longo do país.

6. Todos concordam com a criação do FONAME, mas se questionou se o nome deveria ser Fórum Nacional de Mediação, considerando que os integrantes são limitados ao estado de São Paulo.

7. Foi aprovada, por unanimidade, a idéia de se criar um fórum nacional, que buscará, no futuro, agregar instituições de outros estados. 
8. Professor Freitas apresentou o Regulamento Interno para debates e aprovação, destacando a natureza informal do FONAME, sem personalidade jurídica, constituída por outras entidades.

Foram estabelecidas regras de procedimento importantes, como encontros, pauta, andamento trabalhos entre os intervalos das reuniões.

É importante que sejam eleitos dois coordenadores, com mandato de 2 anos, bem como uma secretaria executiva dos trabalhos.

9. O Regulamento Interno foi discutido e aprovado (Versão final anexa).

10. Foram eleitos os Coordenadores do FONAME.

\section{Coordenação Executiva:}

Dra. Célia Zapparolli

Dr. Adolfo Braga

\section{Comitê Consultivo:}

Dr. Kazuo Watanabe

Dr. Caetano Lagrasta

Dr. Antônio Freitas

Dra. Rosane Mantilla

Dra. Mônica Gallano

11. Para o próximo encontro, a pauta será avaliar os critérios mínimos para a formação de mediadores, a ser elaborado por comissão formada neste encontro, da qual propuseram-se a participar: Adolfo Braga, Célia Zapparolli, Cássio Filgueiras, Mariângela Coelho, Juliana Demarchi, Reginandrea (sugestão de Dra. Célia), Valeria, Nilda, Lia Sampaio.

12. Inicialmente, o CEBEPEJ irá sediar as reuniões e secretariar os encontros, até que o FONAME se estruture.

13. Próximas reuniões: dia 25 de outubro, às $9 \mathrm{~h} 00 \mathrm{~m} / 22$ de novembro, as 9h00m, no CEBEPEJ.

14. Lista de presenças anexa.

15. Dr. Kazuo Watanabe sugeriu que a coordenação realize uma espécie de folder do FONAME, contendo seus objetivos e o resumo das atividades de cada uma das instituições integrantes do FONAME. 


\title{
FÓRUM NACIONAL DE MEDIAÇÃO \\ - FONAME -
}

\author{
REGULAMENTO INTERNO \\ (Aprovado na reunião plenária de 13 de setembro de 2007)
}

Art. $1^{\circ}$. Fica instituído o Fórum Nacional de Mediação - FONAME, integrado, voluntariamente, por entidades de qualquer natureza ou núcleos regularmente constituídos, que se dedicam ao aperfeiçoamento, à divulgação e à prática da mediação de conflitos, e que sejam:

I - formalmente organizados; II - direta ou indiretamente interessados ou ocupados com solução pacífica de conflitos;

III - aceitos por decisão plenária, mediante indicação de qualquer das entidades integrantes.

Parágrafo único: as instituições presentes no ato constitutivo são integrantes do FONAME, bem como as demais, aceitas na forma do inciso III deste artigo.

Art. $2^{\circ}$. O FONAME tem por objetivo:

I - difundir a cultura da paz;

II- - promover a contínua troca de idéias e o intercâmbio de experiências entre profissionais e estudiosos da mediação e de outros meios de solução pacífica de conflitos;

III- formular e definir critérios ou indicadores destinados a constituir parâmetros, mínimos e/ou ótimos, a serem observados:

a) na capacitação, na formação e na sensibilização para meios de solução pacífica de conflitos;

b) na qualificação de profissionais em meios de solução pacífica de conflitos;

c) na orientação quanto a preceitos e procedimentos éticos, a serem observados por profissionais, voluntários, servidores e estudiosos devotados à promoção de meios de solução pacífica de conflitos;

IV - - promover eventos que se ocupem dos meios de solução pacífica de conflitos. 


\section{FÓRUM NACIONAL DE MEDIAÇÃO \\ - FONAME -}

IV - opinar sobre proposituras legislativas e contribuir para a produção normativa sobre meios de solução pacífica de conflitos.

Parágrafo Único - O FONAME não realizará, diretamente nem por interposta pessoa ou entidade, as atividades mediação, formação e capacitação.

Art. $3^{\circ}$. O FONAME terá um Comitê Consultivo composto por 5 (cinco) membros e 2 (dois) coordenadores executivos, todos eleitos por maioria, em plenária, por voto aberto dos presentes, com mandato de dois anos.

Parágrafo Único - Aos coordenadores, em conjunto ou separadamente, caberá a presidência das reuniões plenárias, bem como a supervisão e a orientação da secretaria executiva do FONAME, secretaria que ficará sob a responsabilidade de uma das entidades integrantes, preferentemente em regime de rodízio.

Art. $4^{\circ}$. O FONAME reunir-se-á, ordinária e periodicamente, em plenária, preferencialmente às terceiras quintas-feiras dos meses de março a novembro, entre 9:00 (nove) e 13:00 (treze) horas; em local a ser previamente indicado.

$\S 1^{\circ}$. - Os temas e itens integrantes da pauta das reuniões plenárias serão previamente definidos na plenária imediatamente anterior.

$\S 2^{\circ}$ - Quando, a juízo de dois terços dos presentes em plenária, for considerado conveniente e oportuno, poderá o FONAME reunir-se em plenárias extraordinárias, convocadas com razoável antecedência, para tratar de assuntos constantes de pauta definida na forma do $\S 1^{\circ}$. deste artigo.

Art. 5'. Por decisão de plenária, o FONAME poderá constituir Comissões ou Grupos de trabalho temáticos, preferentemente de caráter temporário e com termo previamente fixado para $\mathrm{o}$ encerramento de seus trabalhos, direcionados ao aprofundamento de estudos, quando necessários ou úteis às definições de plenária. 


\section{FÓRUM NACIONAL DE MEDIAÇÃO \\ - FONAME -}

Parágrafo Único - Caberá aos integrantes das Comissões ou dos Grupos de Trabalho definir suas normas de funcionamento, sempre buscando conciliar a observância da regra de maioria com o propósito de oferecer relatórios consensuais ou, na sua impossibilidade, de relatórios que contenham todos os votos e/ou sugestões minoritários, de modo a proporcionar o mais amplo e esclarecedor debate em sede de plenária, a quem exclusivamente caberá decidir sobre a matéria em nome do FONAME.

Art. $6^{\circ}$. Para as deliberações de plenária mencionadas neste Regulamento será necessário o quorum de um terço das entidades integrantes do FONAME, tomando-se por base a média do número de entidades presentes, ou justificadamente ausentes, nas últimas três reuniões, por meio de representantes formalmente por ela indicados

Art. $7^{\circ}$. O presente REGULAMENTO entra em vigor na data de sua aprovação e poderá sofrer alterações ou acréscimos mediante aprovação de dois terços dos presentes, em plenária especialmente convocada para esta finalidade.

São Paulo, aos 13 de setembro de 2007. 